\title{
A Selection From the War Diaries of Dan Davin
}

by

Thomas Owen McLean

A thesis submitted to Victoria University of Wellington in fulfilment of the requirements for the degree of Master of Arts in English.

Victoria University of Wellington

Te Whare Wānanga o te Ūpoko o te Ika a Māui

2016 


\section{Contents}

$\begin{array}{lll}\text { Contents } & \text { ii }\end{array}$

Abstract

Introduction iv

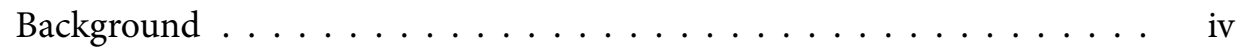

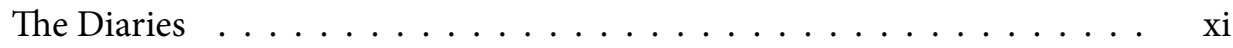

Historical Significance . . . . . . . . . . . . . . xiv

Literary Significance $\ldots \ldots \ldots \ldots \ldots \ldots \ldots \ldots \ldots \ldots$ xix

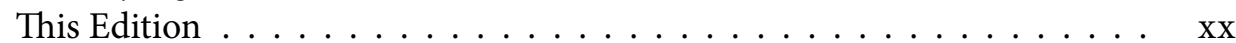

Acknowledgements ................... xxii

1940

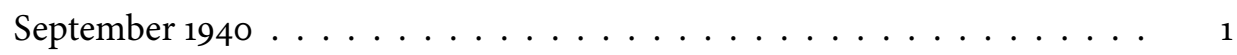

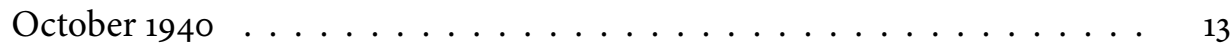

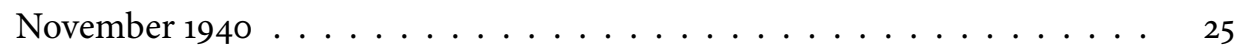

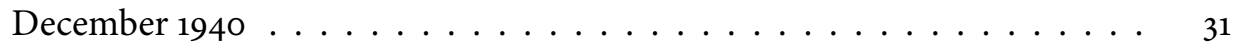

$1941 \quad 48$

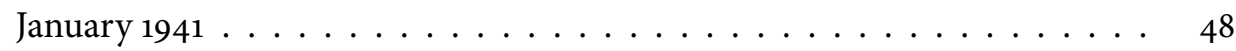

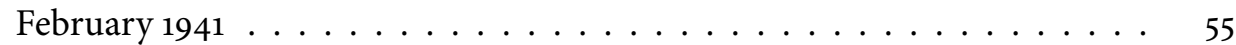

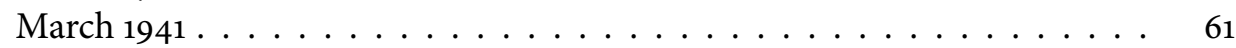

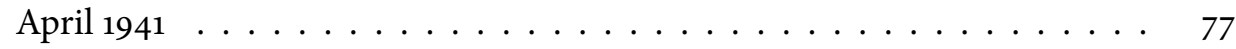

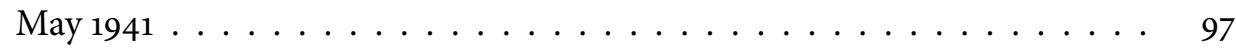

Appendices 120

Appendix A: The Relationship Between Diaries and Fiction . . . . . . 120

Appendix B: Sample Images . . . . . . . . . . . . . . . . . . 125

$\begin{array}{ll}\text { Notes } & 127\end{array}$

$\begin{array}{lr}\text { Bibliography } & 138\end{array}$

Unpublished Sources . . . . . . . . . . . . . . . . . . . . . 138

Published Sources . . . . . . . . . . . . . . . . . . . 143 


\section{Abstract}

This thesis is an edited selection from Dan Davin's wartime diaries, running from 1940-1941 and covering training in England, travel through Egypt, and fighting in Greece and Crete.

The selection is a scholarly edition combining the two extant versions of the diaries (Davin's original manuscript and a typescript copy he made some years later) with heavy annotation.

The diaries themselves are examined in two ways; as a historical record, showing the lives of many New Zealand soldiers; and as an attempt to explore how the inchoate material of the diaries is transformed into Davin's later fiction.

The first draws particular interest from Davin's perspective as both a junior officer, with an account of events from below, and a self-conscious outsider who after escaping provincial New Zealand feels he has returned to its traveling manifestation. He observes with a sense of detachment from his counterparts and from responsibility for events outside his own sphere of command. This gives new insight into what has become part of national mythology. 


\section{Introduction}

\section{Background}

Dan Davin (1913-1990) was an author, a publisher, a soldier and a raconteur. Born in Invercargill but of Irish and Catholic descent, he spent most of his life in England but remained uneasily aware of himself as 'an antipodean, a topsy-turvy man, an Irishman who was not of Ireland.' In some ways, he spent his life, like Graham Greene, in looking for ways of escape; and yet these were balanced delicately with a longing to return never quite strong enough to initiate action.

\section{Before the War}

\section{In New Zealand}

The first escape came early. Davin's educational prospects in Invercargill were limited; convention demanded that he go to a Catholic school. Prior to state integration, these depended mostly on the unpaid labour of religious and contributions by parents, with limited state aid. The Marist Brothers to whom he was sent recognised his obvious talent and arranged a scholarship to Sacred Heart College, a better-resourced Marist secondary school in Auckland. 'Good teachers, as always, made good teaching' and he was one of four students in his year to receive a government university scholarship. ${ }^{2}$ He received the second-highest marks at the school, beaten by his friend M.K. Joseph.

Discussing his near-contemporary Norman Davis, Davin recalled that such scholarships were

particularly vital to people like ourselves, the children of relatively poor parents and therefore dependent for advancement - a university education, in fact - on such beginnings; and, once established in the university of our choice, which would usually be determined by its proximity to our families, in order to survive and go forward we would still be locked in constant struggle with the ablest young men and women of our generation for further prizes and scholarships. ${ }^{3}$

The university in closest proximity to Davin's parents was Otago, 'a town which', he said, 'strangles the heart and yet gives it intimations of a world beyond, escape and 
freedom.' ${ }^{4}$ Studying there, Davin advanced through the cursus honorum with notable success, so much so that a friend's diary in wartime Libya records:

He also tends to stress his brilliant academic career - in NZ of all places.

What does he take me for?

But then came the final step. The 'only escape route that seemed conformable to my abilities and penury and ambitions was that of the Rhodes scholarship. ${ }^{6}$ Here Davin failed.

In later life, he would blame this on suburban scandal. An acquaintance named Bill MacDonald's abortive attempt at a bank robbery left MacDonald's mother, a significant figure in a small society, looking to exonerate him. She found a cache of letters sent to MacDonald by one of Davin's closest friends, a medical student named Geoff Flavell. She seized on these as a way to show how her son had been corrupted by dangerous young men who wrote in green ink; Davin was mentioned.

Flavell had to leave Otago and restart his medical studies in London. Fifty years later, he could still be found writing to Davin about it:

Have you read Richard Cobb's "A Classical Education"? His early experiences bear a close resemblance to mine: but the mad woman who pursued him was eventually murdered by her son, and he suffered a great deal less in consequence. Also she had less local influence. ${ }^{7}$

Davin was not himself overtly harmed, but saw the gossip that flowed from his association with the scandal as having ruined his chances. The bitterness he felt at the behaviour of some students lasted for many years. His antagonism towards William Hawksworth, the president of the student union, notably lasts through several wartime re-encounters. But Otago was also the place where he met many friends, and, most importantly, his future wife, Winnie Gonley, another Southland Catholic.

\section{Oxford}

A second attempt at a Rhodes, after a year studying Latin, succeeded. Davin left New Zealand in August 1936 to study classics at Balliol. There appears to have been no particular reason to choose Balliol, except that 'J.N. Findlay then Prof of philosophy in Otago thought it wd suit me. ${ }^{\prime 8}$ His reasons for studying classics, thought Northrop Frye, who met him at Oxford, were obvious. He was 'one of those unfortunates who are interested in nothing but modern literature, and take classics because they think it will be good for them.' ${ }^{9}$

At Oxford, Davin was both older and more class-conscious than his contemporaries. A collegiate life inevitably led to the making of many more acquaintances, but his closest friends tended to be other expatriates. These were mainly North American Rhodes Scholars who, like him, were older and studying towards a second degree. To younger Englishmen, like John Willett, who first met him there, he was 'this very, very solid 
character with what seemed to me like a rather battered face who also seemed like someone to take very seriously' rather than an approachable friend. ${ }^{10}$

After finishing his degree, Davin, naturally gloomy, foresaw 'a short journey to a grave in France' once the now obviously imminent war began. ${ }^{11}$ Winnie had followed him to Oxford, supposedly after she 'set fire to the family store to collect the insurance money to pay for the journey to England to join him. ${ }^{12}$ A wedding had been delayed by the condition that Rhodes Scholars be bachelors; now free of this stipulation, marriage in England was followed by a journey to Paris, where Davin had often gone in the university vacations.

Soon after their arrival, on the morning of Davin's twenty-sixth birthday, Poland was invaded. They made an abrupt departure.

\section{In Wartime}

By October, Davin was boarded as an officer cadet, and in mid-November he was sent to the Royal Warwickshire regiment. This was a time of what Davin liked to refer to as two gestations; he was writing his first novel, and in late November Winnie revealed that she was pregnant.

In January 1940, as the Manchester Guardian published his first short story, Davin began his wartime diaries.

\section{England}

Davin's war began in the English army, but after he was commissioned in May 1940, he requested that he be transferred to the New Zealand army, having heard that part of it would be diverted to England in anticipation of the threat of invasion. There was a wait for this group of units, the 2nd Echelon of 2 New Zealand Division, to arrive, but he joined them on the 2oth July 1940, the day his daughter Anna was born. He was assigned to 23 Battalion, recruited from Canterbury and Otago, and quickly became the commander of 13 Platoon, C Company.

The reader of his early diaries feels a little like the Warden of Rhodes House, who wrote to the New Zealand selection committee (in an otherwise positive report) that Davin was 'Not an easy man to read, and I do not feel that, at present, I have got the measure of his character and promise, ${ }^{13}$ or like Davin himself, writing to Howard Kippenberger: 'How wise you are to read war history and not write it. Every face begins to shimmer when you come up close to it, like the air in the Western Desert at midday.' ${ }^{14}$

Davin intended to be a writer, but had barely begun. Without lapsing into what Davin calls 'the prim failures of charity with which the stainless academic is apt to afflict those dead before his time, ${ }^{15}$ it is fair to say that the great charm of his character is partially obscured by a vanity and a prickly self-defensiveness about who he had become that does him no favours when read. Many years later, Davin, while 'engaged on a very penitential and chastening exercise: typing out some early wartime diaries,' 
found himself confronted 'with the inescapable evidence that one was a monumentally conceited and egotistic prig...' ${ }^{16}$

The reader may not find it as bad as that, but Davin nevertheless reacted badly to being thrown back into a New Zealand army that valued conformity and obedience after a long process of escaping from New Zealand and communal identity.

Sometimes the diaries feel like five-finger exercises in how to write; sometimes as a way to vent private spleen or individuality when surrounded by obstreperous juniors and complacent superiors (the tension of waiting for a supposedly imminent invasion exacerbates this tendency); and sometimes as a process of observation, either for its own sake or to provide material for later writing.

Davin remains unsure whether he is making a homecoming to a travelling New Zealand or returning to the despised conformities of Invercargill and bourgeois Dunedin. This sense of uncertainty is reinforced by the recurrence and interaction of previously separate groups of people. He encounters a few he knew at home in Invercargill or at school, now mostly forgotten. Otago contemporaries reappear, either as pleasant surprises or as yet more reminders of iniquity and provincialism. Sometimes in the desired distance, and sometimes as models of tired elitism, he catches glimpses of Oxford friends and acquaintances. (These artificial boundaries, of course, overlap: by way of example, as they left France, the Davins thought they were leaving behind M.K. Joseph and Northrop Frye to be captured on the German border. ${ }^{17}$ )

The diaries go on. The battalion spent the summer in Kent, watching dogfights overhead and waiting for a possible invasion. As the possibility of this receded, the brigade departed for Egypt to join the 1st Echelon, the parts of the division which had left New Zealand before them. After a long journey around Africa, they arrived in Egypt in March 1941.

\section{Greece and Crete}

The other lieutenants in the battalion were Davin's closest companions at this point, including the two other platoon commanders in his company, Sandy Thomas and Rex King. His social circle included these and the other officers of the battalion. The gap between officers and men was maintained, despite his pugnacious social attitudes. This barrier, loosely applied in the case of friends who appeared as other ranks, like Geoffrey Cox - re-encountered as a private in England - was strengthened rather than diminished by the rapidity with which friends in the ranks were promoted. ${ }^{18}$ This progression was hastened by the heavy casualties shortly to begin.

After a few weeks in Egypt, the battalion was sent to Greece on an expedition in which everyone involved anticipated failure. In one diary, Davin wrote about how he had 'grave doubts as to the expediency, though none as to the obligation, of trying to hold Greece' (p. 79); in another, his commander, Herbert Thomason, wrote about 'the hopelessness of the venture into Greece. ${ }^{19}$

There was a glimpse of the future when Davin saw, on the ship carrying him over, someone he had heard about either from Geoffrey Cox or a padre friend, Ted Forsman. This was Paddy Costello, at this time a lance-corporal. Sensing the boundary between 
officer and other-rank, he did not approach him, or record the incident in his diary. Costello, within a few months, was an officer and, after Davin re-encountered him in Cairo, became perhaps his closest friend.

The campaign in Greece resolved itself into a succession of retreats as the division's Greek allies fell back against overwhelming force. Davin first saw combat on the slopes of Mt. Olympus. Holding a defensive line there, his platoon was on the $16^{\text {th }}$ of April (not, as his diary has it, the $15^{\text {th }}$ ) attacked by small numbers of German mountain infantry. A successful stand was rapidly followed by a long and arduous retreat in darkness when the Greek forces holding the right collapsed, threatening the battalion with being surrounded and captured.

As the retreat continued, Davin was evacuated on the $22^{\text {nd }}$ of April with suppurative balanitis. He arrived recovered on Crete to find the battalion already there, with few casualties but terribly short on supplies. They were being reorganised to defend the island from a coming attack.

On May $13^{\text {th }}$, as this re-arrangement continued, the battalion's intelligence officer, Brian Bassett, was shifted away. Davin replaced him, briefly. On the first day of the Germans' airborne attack, he was shot in the thigh and the hand while investigating a parachuted canister of enemy supplies. This almost certainly saved him from death or capture. He was evacuated by the same ship that brought Evelyn Waugh in. Meanwhile, his fellow subalterns King and Thomas, trying to evacuate with their own and Davin's platoons, found themselves outside the Cretan village of Galatas. They organised a successful bayonet charge to take the village. This was one of the more famous actions on Crete, but both were wounded and then captured.

\section{Middle East}

Davin was hospitalised in Cairo, fit for some time only for a base job. A report he wrote there on the invasion of Crete attracted the attention of GHQ Intelligence. A long period working there resulted, interrupted and constrained by a succession of illnesses more serious then, before antibiotics were widely available: an infected toe, jaundice, diptheria, tonsilitis. His duty there was to evaluate enemy intentions and movements; he was 'responsible for enemy order of battle in the Balkans and Greece'.$^{20}$ This period is the best-described in his diaries, given the time and certainty he had in which to write.

Cairo at this period was a city filled with poets, a 'colorful place in some ways remote from the war ${ }^{21}$ in which, Lawrence Durrell recalled, 'it seems at times that every poet and painter from London was in our midst. ${ }^{.22}$ Davin described it as

full of a vast variety of unusual, eccentric, well-read and cultivated people from all over Europe. White Russians, Armenians, Copts, French, educated Egyptians of cosmopolitan bent, German refugees, Italians and Greeks. And, of course, the concentration of poets and teachers associated one way or another with the British Council and driven down here from 
every part of the Balkans. It was a world full of charms for any expatriate NZ intellectual. ${ }^{23}$

This, too, was a homecoming of a kind. He worked with many Oxford acquaintances, in an environment 'not unlike the atmos. of an Oxford common room, somewhat speeded up. ${ }^{24}$ But he was increasingly aware of himself as a New Zealander, chafing while the division he had escaped from went into action again and again, 'a diminishing crowd. Everyone gets it in time. ${ }^{25}$ The escape was balanced with a sense of loss. He would later remember the feeling of 'conversations in Cairo or in Bari when I ran into old friends after I had left them for a job on the staff. One had a slightly deprived and self-reproachful sense of having been absent from where the action was. ${ }^{26}$

But Cox and Costello also reappeared from time to time, as did men from the Div on leave, and Davin eagerly wrote down their stories of the desert. ${ }^{27}$

The mixture of people was astonishing. Davin could be found living with Cox in a flat belonging to a friend, Henri Curiel. Curiel was a de jure Italian Egyptian Jew who claimed that 'the only country to which I felt I belonged was France. ${ }^{28}$ In this time he would found the Egyptian communist party and be arrested, to Davin's disgust, 'without the knowledge of the British [...] to offer the future German conquerors one of those communist Jews for whom they had such a sweet tooth. ${ }^{29}$ After a lifetime of revolutionary activities he was assassinated in Paris. Meanwhile, Davin walked from there each day to an office where he seethed at his officemate, one Enoch Powell.

Eventually, Davin was sent out to the desert. Davin did not at first go to the division, but rather to a new unit, J Squadron. Their job was to listen to radio transmissions from the front line, use them to make some sense of the current position, and transmit a summary of this information to army headquarters. There began a period of continual movement across the desert after the breakout at El Alamein. On the 23 November Davin heard that he was to be recalled to the division, 'prob. either to be IO or GSI 1, but he suggested I might even go back to battalion for a while. ${ }^{30}$ Meanwhile, he waited for his relief, until on the 28th January 1943 he returned to the division. With his future finally settled - he was to be Paddy Costello's immediate superior - return to the division meant leaving it, to qualify for his new role at Staff College. ${ }^{31}$

He returned in May, to find that 'Hostilities had just ceased' ${ }^{32}$ in North Africa. He and Costello embarked with the rest of the Division on the long journey back from Tunisia to Egypt; on arrival, they tossed for who could go on leave. Both were entitled to it, but one needed to remain. Davin won.

\section{England and Italy}

After 'a three month's leave in England that had taken six months, half of it on troopships dodging submarines'33 (as the narrator of 'Psychological Warfare at Cassino' puts it), Davin returned much more quickly by way of the Mediterranean to find the division at Monte Cassino. He worked with Costello for a long while, then replaced 
him as the main divisional intelligence officer when Costello departed. The winter stretched on; on the $18^{\text {th }}$ of June, Cox returned from a diplomatic posting in America. Davin now had a replacement available, and on the $27^{\text {th }}$ of July he left Rome.

Costello had tipped him off about a London job, closer to Winnie: he became 'G.S.O.2, Documentation Sub-Branch, Intelligence (IA) Branch, Army Division, Control Commission (B.E.) (new appt.)'34

His useful translation of this was as 'something to do with the organisation of Germany's postwar military disorganisation. ${ }^{35}$ At this point, as he embeds himself in the nightlife of Soho and begins to write his second novel, the diary comes to a gradual end.

\section{After the War}

After the end of the war, Davin remained in England, struggling sometimes with the revelation that 'once one has been an expatriate, one is never quite able to settle again whichever country one is in: one has regrets for the other that one has left. At least that is so with me. ${ }^{36}$

He rose to prominence at Oxford University Press. While he continued to write, this was only a part-time occupation. He nevertheless produced many novels and short stories, as well as the volume on Crete for New Zealand's official war histories. This involved a careful balancing of arguments to imply that the loss of Crete was inevitable while hinting that this need not have been the case had Maleme been held. His wartime experiences also found their way into nineteen short stories, eventually collected in The Salamander and the Fire, and one novel, For the Rest of Our Lives.

Any plans to write fulltime after retirement were prevented by alcoholism and recurrent depression, although he wrote some criticism and poetry, as well as drafting a memoir of Paddy Costello and another of Bernard Freyberg.

Although his grouped memoir of friends, Closing Times, remains masterfully done, his literary output now seems less important than his influence as the last of the major New Zealand writers who went into voluntary exile in England (excepting Fleur Adcock), and the role this gave him as an accoucheur to the next generation of writers who stayed behind.

For thirty years from the early 1950 s Davin was recognised in Britain as the informal ambassador of New Zealand letters, and his friendships, connections and in particular reviews in the TLS did much to bring generations of New Zealand writers to a larger public. ${ }^{37}$

There is one full-length biography of Davin, Keith Ovenden's A Fighting Withdrawal $3^{8}$ James Bertram wrote a short biography and discussion of Davin's literary output, ${ }^{39}$ and Davin is one of those discussed in James McNeish's Dance of the Peacocks. ${ }^{40}$ A collection of reminiscences of him was edited by Janet Wilson. ${ }^{41}$ 


\section{The Diaries}

\section{Details}

The wartime diaries take up thirteen folders in the Alexander Turnbull Library.

There are six manuscripts, covering 1940 to 1945 . These exclude the volumes covering 1941, which are missing.

The manuscripts tend to be small notebooks - one is an address book - used primarily for the diaries, although addresses and records of letters sent are often written on the covers. The second manuscript for 1940 begins with jotted notes on military exercises and lectures before moving on to the diary itself. In other cases, drafts of poems or short stories are included between diary entries.

The manuscripts are accompanied by transcripts and separately-filed carbon copies typed and lightly annotated by Davin in bursts of activity: in October 1977, in the latter half of 1979, resuming briefly in October and then November 1980, and then in December 1981 and January 1982. These include copies of the missing volumes, but do not include the additional material in the manuscripts, except when some of the poems are copied. A sample page of both the manuscript and typescript is given in Appendix B.

The diaries therefore cover training in England, transit in Egypt and battle in Greece and Crete. After Davin's wounding on Crete, the most voluminous entries cover life in wartime Cairo for more than a year while he works in Eighth Army Intelligence. This period is split in two. The first series of entries runs from January 1940 to December 1941; the diary resumes in April 1942 with the comment 'Lost this year's volume of diary on Saturday. Very upset.' 42

The action then shifts to the desert as Davin interprets radio chatter with J Squadron until the beginning of 1943. Returning to the New Zealand Division after staff training barely covered in the diaries, Davin arrives only in time for the long journey back across North Africa after the end of the desert campaign before going on leave to England. This is only briefly described, before a verbose return to Italy. After arrival in London, the diaries peter away.

\section{Transcription}

The reason Davin embarked on this long process of transcription is uncertain, but there are four possible motivations. These are, perhaps, each individually unconvincing but when combined sufficient.

As Source Material The first was to go through the diaries hoping to find material for stories. Davin published five stories set during the war from 1980 to 1986. These were later collected along with his earlier war stories in The Salamander and the Fire. The later stories - 'The Dog and the Dead', 'Finders and Losers, 'Cassino Casualty', 'When Mum Died' and 'North of the Sangro' - only draw occasional lines from the diaries. The diaries can be seen as a nimbus of interpretation around these stories. They 
perhaps grew from ideas suggested by the diaries, but this inheritance is not direct or immediately recognisable; present, but not in itself enough to justify the slow process of transcription.

'When Mum Died' provides an example; Davin ends his copying of the diaries with the note 'must now resume short story 'When Mum Died'. 9 Apr 1982.' This story is narrated by a character recognisable as Jonesy, the batman Davin inherited from Costello, describing an officer who is a composite of Davin and Costello. A line in the diaries about Phil Hanna, another divisional officer, having a fire-extinguisher blown into his face while rushing to help extinguish a burning caravan is expanded into a paragraph with identities changed; Kurt Gottlieb, an officer in the English Army loaned to the intelligence staff, is transformed into Karl Marks and given an obsession with an 'Afghan hound bitch.' But the only direct reference to the diaries is the transformation of the line 'Letter from Tom [Davin's brother] to say Mum died 11 May.' into "Letter from Frank,' that was his brother, 'to say that Mum died on 23 March." 43

Soldiers and Scholars Another reason needs to be sought. Davin intended to 'assemble a book of memoirs - called 'Soldiers and Scholars' or something like that - Kip., Freyberg, Paddy, Kenneth Sisam, R.W. Chapman, etc. etc.' 44 Perhaps the transcription was a form of research for the first three subjects, an investigation of what memories were recalled by slow engagement with the existing text.

Paddy Costello But this in itself disguises a related motivation. Davin's bursts of activity correlate strongly with letters about Paddy Costello. Michael King, one of his correspondents, recalled

I said I'd see what I could find out for him. I sent him a page of my relevant interview with Alister McIntosh, who, as head of External Affairs, was Paddy's boss when the latter was both hired and fired from the diplomatic service.

I also managed to acquire, illegally, some security reports on Paddy. I sent them to Dan with a request that he not quote directly from them, nor identify where they had come from. After he died, Delia Davin retrieved these from his papers and returned them to me. ${ }^{45}$

The content of these security reports - 'about half a dozen badly photocopied sheets' ${ }^{\prime 6}$ - is uncertain. All that is known is that they somehow contradicted the established account: 'Keith $\mathrm{O}$ did not see them, and I suspect might have written differently about the issue if he had (there are some things in his text that are just plain wrong.) ${ }^{\prime 47}$

There were four papers, but only one possible candidate survives in King's papers. This is a copy of correspondence about Costello between the English Foreign Office and its High Commissioner in Wellington, Henry Batterbee. 
The other three are missing. A letter from King's editor, Geoff Walker, provides a possible explanation:

I most definitely think that you should get the documentation out of the house - maybe to me, or one of your family, or even a friendly neighbour. ${ }^{48}$ Times have changed but I suspect that at the upper levels of the SIS nothing much ever changes. ${ }^{49}$

King sent copies to Helen Clark in her role as minister responsible for security intelligence when he requested that more information be released, but papers related to her ministerial duties remain inaccessible.

In any case, these reports, whatever their content, provide another explanation.

They evidently caused a reaction. Davin began to look for new evidence to exonerate Costello. As yet, neither exoneration nor conclusive proof of guilt has yet emerged; James McNeish's The Sixth Man goes to some length in attempting to disprove the allegations, and finds weaknesses at several points. On the other hand, 'some significant information relating to Mr Costello was provided to the NZSIS in confidence by a liasion service which, to date, has declined to authorise its release. ${ }^{.50}$

A flurry of letters to forgotten friends asked for reminiscences of Costello during the war. Davin hoped they would provide material to rebut 'all sorts of silly bastards [who] have lately been maintaining that he was a Russian spy. ${ }^{51}$ It seems likely that Davin's return to transcribing the diaries was motivated by the same concern, undertaken in the hope he would find some evidence exonerating Costello and have it ready to show the world.

A Legacy The fourth motivation is even more speculative. Davin added annotations to the later typescripts explaining material he would be unlikely to forget, mainly expansions of initials into full names. These annotations would have value only if he intended someone else to read them.

It is therefore possible that he intended for the diaries to be published at some point. There is, however, no evidence that he approached publishers.

It is equally likely that he was annotating with an eye towards a future biographer. This supposition is reinforced by the fact that there are also a few annotations which are not in Davin's hand, two of which are initialled 'W.K.D.' These are most likely to have been by Davin's wife (Winifred Kathleen Davin) and intended to clarify matters for Keith Ovenden, Davin's biographer, to whom the diaries were passed on after his death, although Ovenden does not recall being so told.

\section{Provenance}

The holograph manuscripts are relatively clean texts, with few emendations, but are still recognisably written quickly. It seems very unlikely that there were earlier drafts, although there is one reference to copying in entries. This occurred when the diaries were sent out of Crete for safekeeping. 
The diaries may have been posted back to England; but there are no references to this in Davin's letters, and the state of the mails and frequent complaints about missing correspondence suggests that except in this instance, Davin would have taken them himself when going on leave.

There is no record of the diaries between when Davin returned to England and a few mentions he makes of transcribing them in letters beginning in 1979. It is likely that no-one but he and Winnie read them before his death, when they were found in his bedroom; his daughters do not think so, and had not read them.

After Davin's death, the diaries were passed on to Keith Ovenden, who used them while writing his biography. They were then given to the Turnbull, which had bought Davin's papers.

\section{Historical Significance}

\section{Relevance and Comparison to Other Sources}

The diaries are a unique historical source. They are balanced between the records of life in wartime left by senior figures in the division and the more recent publications of diaries and letters of enlisted men. Davin is senior enough to be able to provide a balanced and, most importantly, informed view of action, while he is still junior enough to be relatively unguarded and to have his experiences more generally applicable. As well as the particular interest to be found in Davin's perspective as both a junior officer, with an account of events from below, it is important to note that he is also a self-conscious outsider who after escaping provincial New Zealand feels he has returned to its traveling manifestation. He observes with a sense of detachment from his counterparts and from responsibility for events outside his own sphere of command. This gives new insight into what has become part of national mythology. Davin's education and relative experience of the world compares favourably with the brieflykept diary of Sandy Thomas, and with the official histories of the war.

These official histories have been valuable, especially that of 23 Battalion, written by Angus Ross. But they are also not wholly reliable. Without mendacity, Ross and his correspondents emphasise the heroism of the battalion and consciously shape the account to, as he said, 'help inspire infantry soldiers of the future. ${ }^{52}$ In Rachel Bell's excellent discussion of the official histories, she argues that:

While 23 Battalion was a skilled and thorough piece of historical research it also demonstrated how empirical aspirations met with the more subjective personal and national interests of its author under the War History project. Structured and informed by Ross' training as an empirical historian, it equally reflected his pride in his Battalion and his ongoing interest as a Territorial commander in the psychology and strategy of warfare. [...] Empirical methodology was coupled with the affirming and familiar schema of the heroic quest to frame the war experience for the Battalion's soldiers and to carry its story out to their families and the national readership. The 
meticulous ordering and detailed analysis of engagements was set against an invented tradition with the intention of inspiring not only pride in the memory of participants but also the call to service among generations in the future. ${ }^{53}$

In fairness, Ross's heroic account is, at least, more accurate than the battalion's war diaries, an obvious source which in practice have been distinctly unreliable. According to Gordon Cunningham, another officer in 23 Battalion, 'It used to be a common joke that "if only they had a war-diary per platoon the war would soon be won" as there were so many more Germans killed in the war-diary than on the ground. ${ }^{54}$

Davin is relatively free, though not immune, from this bias towards heroism. This is unlike another, otherwise similar, source used by Ross and drawn on for this edition. These are letters written by Brian Bassett - Davin's predecessor as 23 Battalion's intelligence officer - to his wife. Bassett's voluminous letters have been a major source in understanding the day-to-day life of the battalion and its personalities. They are vivid, entertaining and very detailed. They are, however, perhaps a less relevant and reliable source than Davin; their provenance is uncertain, in some cases they are demonstrably inaccurate, and they appear to have been censored by several different hands. By comparison, one of the great advantages of Davin's diaries is that they are written at the time and unedited, unlike the nearest equivalents in the New Zealand Division, his friend Wig Gardiner's memoirs. It is much more intimately associated with the division than another similar text, John Mulgan's Report on Experience.

The copies used of Bassett's letters are in the Angus Ross papers at the Hocken. Bassett's wife copied the letters after Bassett's death, hoping to find a publisher. She enlisted Alf Jeavons, a former IO of the battalion, in this task. ${ }^{55} \mathrm{He}$ sent them to Geoffrey Cox in New York; Cox did not find a publisher, and there is in fact no evidence that he did anything with the letters. The only proof he received the copy sent is that several of Bassett's photographs can be found, unattributed, in his wartime scrapbook..$^{56} \mathrm{~A}$ quotation from the letters appears in a BBC programme about Crete written by Davin; ${ }^{7}$ he may have been sent Cox's copy, but the letters also somehow found their way to the War History Branch, where he could have seen them. It is not clear if this surviving copy is the same one sent to Geoffrey Cox, or another altogether, but is clearly an original manuscript. It was copied twice at the War History Branch but is now apparently the only survivor. It passed through the hands of John Clark, the original compiler of documents about the battalion, Howard Kippenberger - who questioned Bassett's accuracy $^{58}$ - and finally to Angus Ross, who kept it until his 2001 death. One likely reason for the 'great difficulty in having the letters published'59 is Bassett's gusto in - unlike Davin - telling stories about anyone and everyone, however discreditable. Freyberg appears misidentifying goat droppings; Charles Upham is pronounced a hero for killing prisoners-of-war, ${ }^{60}$ and so on. These episodes survive but Kippenberger and Ross both censored other portions. Someone, probably Ross, annotated some of the letters with expanded names and dates of death. 
But Bassett died in the desert. His letters cover only half of the war, unlike Davin's coverage of the whole.

Another comparable case is Paddy Costello's diary. A substantial portion of it survives in private hands, but it has not been used to any great extent in this thesis, and is unlikely to be valuable for historical research. It deals almost exclusively with times when Davin is not present, with the exception of their journey back to Cairo after the end of the desert campaign. An earlier portion is missing; Costello believed Davin accidentally took it with him on leave, but this is unlikely to have been the case. Davin spent some time trying to access Costello's diary after his death, but was forestalled by his widow. This was perhaps done to avoid causing offence, as many references to Davin are unflattering.

Costello's diary is frankly solipsistic, consciously written as an exploration of his interior state. The exterior world is significant insofar as it impinges on the interior, not in its own right.

\section{Reliability}

These reasons that Davin's account is unique and offers new information should not be taken to mean that Davin's writing is free from any pressures to omit or occlude information; nor should the volubility with which he denounces personalities be taken to mean that he felt free to denounce greater weaknesses.

There are three notable reasons for omission in Davin's account. These present problems in naïvely using the diaries as a historical source. Davin omits details to protect his own reputation. He also does not give details of the 'secret history' of the division's failings, even when he knows them. Finally, he avoids giving details which might be of help to the enemy if his diary were to be captured.

\section{Davin's reputation}

One example of the first class of omission is the exact circumstances in which Davin left GHQ.

The version he gave in later life, not directly contradicted by the diaries and followed by Ovenden, is that Costello's attempts at a transfer attracted the attention of Bernard Freyberg, commanding 2 New Zealand Division, and left him looking for other talented officers seconded to the British army. (The briefest version of this story is in 'Psychological Warfare at Cassino', where a narrator obviously reminiscent of Davin tells us that Freyberg 'discovered that I was seconded to British Intelligence at GHQ, Middle East. He knew nothing else about me then, but on the principle that, if the British wanted me, he must, he had winkled me out and back to NZ Div.' ${ }^{61}$ )

James McNeish believes in a slight variant of this story: that this was a deliberate strategy on Freyberg's part, setting up a pipeline of intelligence officers to replace one another.

Davin's story is unlikely to have been the case. Freyberg was acutely aware of the location of his staff officers; he was very short of them, since many were being sent 
back to New Zealand to arrange training and home defence against the new Japanese threat; and resisted vigorously a series of proposals from October 1941 to February 1942 from Auchinleck, the commander Middle East Forces, to send any more staff officers to join the ' 15 or so holding departmental appointments' like Davin's. ${ }^{62}$ More recently, Freyberg had visited Davin's office in July. ${ }^{63}$

This certainly does not exclude McNeish's theory, but there is a further consideration. The old colonel in charge of Davin's section was replaced; the new one called him in to his office and told him he was 'bone idle.' 'I grasp this as a polite presentation of alternatives: work and you get promoted. Loaf and you get out. ${ }^{64}$ Two days later, he decided to take a half day off, 'with some temerity considering my precarious position. Before I was walking on the handle of the knife, now I am walking on the blade.' And two days after that he makes a bald note: 'Rejoining Div on 30 Sep.'

He was not the only officer to disappear at this time: '[...] GHQ Cairo remained a haven for several officers whose only talent lay in who they knew. All this changed under Alexander. Suddenly everybody was expected to work. In the run-up to Alamein [at the end of October] that meant at least a ten hour day, seven days a week. Anyone who failed to keep up was packed off to his regiment at the front.' ${ }^{35}$

At the end of September 1942 there is a bald note in Davin's diaries: 'Rejoining Div on 30 Sep.' But the division, when he arrived, had no role for him, implying that they had not requested him and did not anticipate his arrival.

A slightly different case is the two wartime affairs Davin conducted; neither is mentioned overtly in the diaries.

\section{The Reputation of Others}

Davin also displays a curious differentiation in his judgements. He is very willing to complain about the personalities of others, but there are limits beyond which he will not go. Denigrating military skill is something which he is reluctant to do, even through a succession of defeats. Another is a reluctance to mention anything likely to cause shame for others. In some cases, he may simply not have known, but this cannot apply to all. The diaries fail to mention issues even when we can deduce that Davin knew of them. One of the more curious features is that in many cases the things Davin fails to mention are later transformed into fiction. This makes Davin's motivations distinctly unclear; he spares no-one's feelings by publishing for the world to see, but will not mention the same events where no-one will see them.

An obvious case is the court-martial of Davin's friend Teddy McCullough for homosexuality, a major plot point in For the Rest of Our Lives. The diaries only make vague references to his being in trouble and mention lawyers and court-martials without ever giving a charge. Another example is two events transformed into one of his more successful war stories, 'Coming and Going'.

The first traceable inspiration for 'Coming and Going' is the officer commanding A Company of 23 Battalion, whom it is perhaps better not to name. This officer at least once, and possibly twice, abandoned his men. He came from Christchurch, was notable 
for his habit of dressing smartly, and was in the territorials before the war. Something uncertain happened on Crete, but there is room for doubt and at least one very strong, if internally contradictory, repudiation by a witness which nonetheless shows that the story was far enough afield that Davin is very likely to have heard it:

To begin with in one letter you asked me if there was any truth in a certain story being spread about at Burnham about the nephew of the friend who sits with you at chapter meetings. I know the story and have done so for about a year. In short, there is no foundation for the imputation. The officer concerned did not hand over the company to me of his own volition. He did it to go on to $2 \mathrm{i} / \mathrm{c}$ the Bn. Secondly he was in a particularly bad way with dysentery and together with at least three officers of the Bn was sent off to make his own way to the South of the Island. This he did and that is the reason for his earlier arrival in Egypt. The intended imputation behind the story is quite wrong and I hope it goes no further. Incidentally, I think that the said officer's decoration, promotion to major, and now in spite of the story his promotion to Temp. Lt. Col., in command of the 26 th $\mathrm{Bn}$, is enough evidence that people in high places are quite satisfied with his showing. That should settle that. ${ }^{66}$

Another suggestive letter survives, but gives no further evidence.

I have already heard from Gordon Cunningham who will make several comments on that Mss. He has some very strong views on [the officer] and thinks his reticence is quite understandable in view of his conduct on Crete. $^{67}$

In another incident, Kippenberger recalled that, in an attack in the desert at El Mreir, ${ }^{68}$ by which time the officer commanded the battalion, he 'lost his nerve when halfway across the depression and that he was the first man back along the track, having deserted his battalion. ${ }^{69}$ Angus Ross also knew of the story, but suppressed it from the official history at Kippenberger's request: 'those poor chaps who have failed have to live with themselves in that knowledge. We can show them the charity of silence. ${ }^{.70}$ This omission was made easier by the officer's capture very shortly after the event in murky circumstances, which meant that no official action was ever taken.

In 'Coming and Going', the narrator, just out of hospital in a transit camp, encounters an officer named Reading who commands A Company of the narrator's battalion, was in the territorials, is notable for the smartness of his dress, and comes from Christchurch. The narrator is too glad to see him to remember 'the night before I got knocked at El Mreir.' ${ }^{71}$ Compelled to drink with Reading, he notices something is wrong when other officers, one named Tiger, avoid him. He gradually discovers that Reading abandoned his unit in an attack. The narrator continues to drink with his friends; in the morning, he discovers that, caught coming and going between death in battle and disgrace at home, Reading chose to shoot himself. 
Details are obscure, but this is reminiscent of the death of another officer, the Labour MP Axel Gordon 'Tiger' Hultquist in transit between units just after coming out of hospital. A passage in Brian Bassett's letters presumably describes his death, but has been literally cut out. A note in Kippenberger's hand says that it is better to omit; Tiger officially died of influenza. (This is the story given in contemporary newspaper accounts; see, for example, the Herald's reporting. ${ }^{72}$ ) From the passages before and after this deleted section it is nevertheless clear that Hultquist killed himself early one morning after drinking with other officers; Bassett moves on to a description of a hungover funeral. The story is confirmed by a telegram to Peter Fraser from Freyberg stating that 'During fit of depression he took his life.' 73 Again, Davin makes no mention of such an event in his diaries, but the parallels are clear.

\section{Aid to the Enemy}

There is also a practical reason for omission on Davin's part. He does not mention things if the loss of his diary, and its reading by the enemy, could in theory aid them. Davin may have seriously believed in this threat, or he may have merely wanted to avoid stating anything that could lead to his diary being confiscated by what his entry for 3 August 1944 calls 'Those damnable security folk who stole my Summaries.'

$\mathrm{He}$ is therefore, for example, exceedingly vague about the nature of his work in Cairo.

Another such example is the case of Norman Davis. When Davin, 'guiltily seated one day at the Balkan desk' discovered a photograph of this Otago and Oxford friend, in a newspaper cutting that informed him 'this vile and venturesome person had been condemned in Sofia - in absentia also, I was relieved to note,' he was driven to make enquiries that revealed Davis was now in Ankara with an unusually large moustache and an assumed name. ${ }^{74}$ Yet none of this, and no records of the people to whom he spoke about Davis, appear in the diaries.

Later in the war, as Davin produces intelligence summaries, the content of the summaries is not given.

\section{Literary Significance}

Excluding those already discussed, the stories in The Salamander and the Fire can be classified in two ways; those based on extracts from the diaries, and those which are only marginally related to the diaries. The first case gives an interesting look at how inchoate facts are transformed into fiction; in the latter, the diaries remain useful in the process of interpretation, as anecdotes Davin records are transmuted or small details from them are added. At the very least, we see the circumstances of creation for Davin's heavily autobiographical fiction; we are given the unusual privilege of seeing what could be called drafts before the first draft.

Several episodes in For the Rest of Our Lives also draw on the diaries.

Specific cases are discussed in Appendix A. 


\section{This Edition}

\section{Rationale for selection of material and copy-text}

This thesis is an edition of the final manuscript for 1940, extended by the typescript diary for 1941 until just before Davin's evacuation from Crete. More precisely, it runs from 8 September 1940 to 23 May 1941.

The diaries as a whole are too large a corpus for the scope of a Master's thesis, so some selection was necessary. It is more desirable to preserve the narrative integrity of a whole section than to present those individual pieces which have the greatest interest; with this in mind, the narrative of training in England to wounding in Crete is perhaps the most suitable. It contains the great arc of Davin's wartime experience, from an uneasy internationalism and individualism to a communitarian pride in his division, but it is also a bildungsroman of great interest. The prickly Davin of the earlier part feels himself to be more and more part of this imagined community, until, wounded on Crete, he can imagine himself home again in Gore.

More practically, the sections on Greece and Crete are those parts Davin most heavily exploited in his later fiction. The limited scope of this selection allows exploration of how the inchoate material of the diaries is worked into structured narrative.

\section{Discrepancies}

It will be immediately obvious that biographical details in this edition, including the spelling of names, sometimes differ noticeably from standard sources.

The description of individual's careers and hometowns given here, for example, differs from Angus Ross's or from the nominal rolls of the division in several cases. The discrepancy arises because Ross appears to have interpreted his instructions to give any named individual's hometown as to give their hometown at the time of writing, not of enlistment. (Or at least to have presented his instructions ambiguously enough that this was often the case. $)^{75}$ In most cases, where enlistment records differ, I have followed these. In several instances, however, addresses given in the nominal rolls differ from those in other sources. There are several explanations for this which make the alternatives preferable: these addresses are often evidently not those of the individual enlisting but a suitable way to hold letters, as in the cases where former employers or social clubs are given when the individual was the only householder. Another common explanation is that the individual enlisted from a relief camp; sometimes this is noted explicitly. Many of those who gave their occupation as labourer on enlistment were actually unemployed and working on one of these schemes. ${ }^{76}$

Davin's use of names is remarkably inaccurate, often giving names as they sounded rather than as they were. Although the correct spelling is used in biographical notes and in the index, Davin's variants have been preserved in the text for ease of reference, since Ovenden tends to follow Davin's spelling without any explanation of this practice. 


\section{Areas for further research}

Len Diamond, a private in Davin's company, kept a diary which was seen by Angus Ross but which is no longer present in Ross' papers. Ephemera belonging to Diamond remain in family hands, but his diary is not present.

Doug Leckie, Davin's battalion commander, kept a diary which is still in family hands. This was traced too late to be used in this thesis.

It is also unclear whether Ginger Evans, Davin's batman, is still alive. He has not been traced since his appearance in the 1946 census, when he was living as a motor tram repairman in Lyttelton.

I was given access to two different groups of copies of Davin's file at the Rhodes Trust Archives, but have not seen the original.

\section{Editorial Practice}

\section{Typographic Changes}

The only method of emphasis used by Davin in either version of the diary is underlining. In the body text, underlined text has been silently changed to italicised text. Headers, represented by underlining or by positioning, have been rendered in boldface type and scaled up depending on the importance of the division they indicate. These differences represent either the manuscript's title, the heading for a particular day's entry, or sub-headings within that entry.

Hyphens in the original text (-) have been rendered as either em-dashes (-) if between words, or en-dashes (-) if between numbers.

Davin's typewritten straight quotation marks and apostrophes have been silently changed to curly quotation marks (", "')").

Whitespace has been normalised so that inter-word spacing and paragraph indentations are consistent. Leading has also been added before and after headers.

\section{Textual Changes}

Following a common practice at the time, Davin's handwritten entries add a space before a colon; this practice is only occasionally followed in the typescript. These cases have been silently emended to modern usage.

Where Davin has added accents by hand to typewritten letters, the letters are rendered with accents without any indication of the change.

Where Davin has deleted text by typing over it, the deleted text is not recorded. However, deletions by hand in both the typescript and holograph are rendered as struck-out text.

Additions by Davin, whether typed or by hand, are rendered in square brackets.

Editorial insertions are indicated with «guillemots».

Unambiguous end-of-line hyphens have been silently removed.

All other textual changes have been recorded in the editorial apparatus. 
In very occasional cases, paragraphing differs between the two versions of the diaries. Here, the holograph text has been followed.

\section{Critical Apparatus}

Two series of notes are maintained. The first records variant readings between the versions of the diaries when both have survived and textual changes made by the editor where only the typescript was available. Readings from the typescript are identified with TS and from the holograph by MS.

The second provides editorial annotations and identifies persons mentioned in the text. A person is only identified here on their first appearance. Afterwards, their presence can be confirmed by reference to the index.

\section{Acknowledgements}

I have received help, advice or information from too many to name. I am particularly grateful to Christopher Costello, Michael Fathers, James McNeish, and the Ministry of Foreign Affairs and Trade for allowing me access to papers; to Will Scarrold for photographing documents in the United Kingdom; to Major-General Sandy Thomas for discussing 23 Battalion with me; to Anna Davin, Delia Davin and Brigid SandfordSmith; and to my supervisors, Peter Whiteford and Charles Ferrall. 


\title{
DIARY CONTINUED
}

\author{
Sunday $8^{\text {th }}$ Sept. 1940.
}

In camp at Milgate, Kent. Lying under home-made shelter from rain in little copse, waiting for news of afternoon leave, if any. Air raid just over, three planes down in vicinity - one British burnt before able to bail out properly. Air raids two or three a day -65 Germans down yesterday. Just written to Winnie and Anna still at Mytchett. Hope to be back in a few days, since invasion rumour seems to have been only a scare.

Amusing though annoying to watch behaviour of men in raids. Refuse to believe any planes down can possibly be British. Very excitable, highly partisan. When Spitfire came down, rumour ran immediately that Germans had landed. Men rushed out with unloaded rifles and no ammunition - one Tommy gun could have inflicted heavy casualties. Such discipline by now will only be corrected and high spirits chastened by very heavy casualties - which will surely come once we get fighting.

Country delightful. First rain this morning for weeks. First taint of autumn gold just touching the trees. Orchards full of fruit, easy prey to hands thrust out from

2 Sunday $8^{\text {th }}$ ] 8 TS 14 autumn] au tumn TS

1 DIARY CONTINUED ] ' 1940 ' is written in red pen in the top right margin.

3 In camp at Milgate, Kent. ] Davin's unit, 23 Battalion, had moved with other NZ units to take up defensive positions in East Kent. Milgate was not a town but a park in the vicinity of Milgate Park, a country house (the setting, incidentally, of Robert Lowell's 'Fall Weekend at Milgate': he lived there thirty years later). The battalion's HQ was established in the house itself, but the companies were billeted out in the surrounding area. 5 bail out ] Parachute from plane. The pilot was Jack Conway Carpenter, a twenty-one year old sub-lieutenant in the Fleet Air Arm seconded to the RAF because of the shortage of pilots. $^{77}$

6 Winnie] Winifred Kathleen 'Winnie'

Davin (1909-1995) Davin's wife.
15 trees. Orchards ] trees and orchards TS
6 Anna ] Anna Deirdre Davin (1940-) Davin's daughter.
6 Mytchett ] A small town in Surrey near where 23 Battalion had previously been encamped; Winnie Davin had followed them there.
7 invasion rumour ... scare] This rumour was better founded than others: the UK Chiefs of Staff agreed on the seventh of September that especially favourable tidal conditions on the south coast meant that an invasion was very likely some time between the eighth and the tenth, and issued a command to be ready for immediate action that evening. 'Amidst the prevailing atmosphere of expectancy reports were received that parachutists had actually landed and that fast German motor-boats were approaching the coast, but on investigation all were shown to be without foundation. ${ }^{78}$ 
platoons on the march. Very pleasant to lie in sleeping bag in late twilight and see silhouette of leaves (ash?) against the sky. Had cold but the open air cured it. Wrote to

If no leave will settle down to read odd scraps of magazines, smoke and sleep. Last night thought of recapture of memory story again. If sleep and dreams can recapture 5 for us the most intense sensations out of the maze of past impressions feasible that by combination of will and dream a chosen pattern of experience could be relived. Difficulty that will does not seem to operate in dream or not the same will. Demands consciousness. Could identification of conscious and unconscious wills be made responsive to waking intention? Good subject for a story anyhow. But which pattern to be selected for re-experience?

\section{Monday Sept 9 th.}

Yesterday went as far as Faversham with Watson, Baxter and Gray in A Coy car. Sittingbourne and Faversham v dreary-looking places. Brakes burned on and so had to wait in Faversham. Dined at the Ship there, nice old pub fallen on bad days: steak, tomatoes, chips, beer. Much shop gossip and animosities. Two more pints on way home. And so to bed.

This morning reconnaissance to Folkestone and Dover. Odd to see the old haunts at Sandgate and Folkestone. But nothing of any note. Role in invasion | described. Lunch tea and tinned fish sandwich.

This afternoon taught Tommy gun with a captured mole as rival entertainer.

Heavy raid at teatime now over. But no local developments. Men from leave turned up with Captain Harvey and Captain Morten. But have seen neither yet. Major Thomason took NCO's for classes.

$13 \mathrm{v}$ ] very TS 13 burned on] bured out TS 15 tomatoes] tmatos TS 20 Tommygun] Tommygun TS 22 Morten] Norton TS

12 Watson ] Carl Nelham Watson (1911-1974) An officer in 23 Battalion. According to Leckie, he worked on the staff of the correspondence school in Wellington before the war. 12 Baxter ] Bruce York Warner Baxter (1907-1969) Commander of 8 Platoon, A Company of the 23rd, a wool clerk from Timaru. His birth certificate has Jack in place of York, the name given in military records and on his death certificate.

12 Gray] James Bridgeman 'Bridge' Gray (1907-1963) Lieutenant in 23 Battalion, a draper from Milton. He was at first commander of the AA platoon - 'Some doubt there being a No.1 Ack-Ack Pl., but I know'79 but when this was disbanded in England he became a platoon commander in A Company. 22 Captain Harvey] Marcus Dalby 'Mark' Harvey (1904-1985) A salesman from Dunedin, normally in D Company but briefly Davin's commander in C Company. After being wounded in the mouth on Crete, he became the manager of the N.Z. Club in Cairo and returned home with the first furlough. 22 Morten ] Thomas Bassett 'Tom' Morten (1913-1975) A shepherd from the Banks Peninsula. Commander of HQ Company, 23 Battalion; later $\mathrm{CO} 25$ Battalion. 22-23 Major Thomason ] Herbert Henry 'Bert' Thomason (1896-1981) A first world war veteran from Stoke, where he was an orchardist. He was acting as Davin's commander in C Company. At this point, he was temporarily in command of HQ Company. He seems to have admired Davin especially; many years later, he asked for his best wishes to be sent to, of all the battalion, 'Sandy Thomas, Dan Davin, and Clive Hulme.' 


\section{Tuesday. Sept 1oth.}

News this morning that we stay here for a month: probably in billets and with no London leave. Profoundly exasperating. When it looks certain enough must devise expedient for getting Anna and Winnie down. Quiet day - nothing in morning, 'tactical' route march afternoon. Men driving me mad w unnecessary wrangles about food. All have a passion for argument, which if they knew anything about debatable subjects could make them very interesting. But they are always about matters of fact, if not factual in content. Mature in every way, except intellectually. Latrine boundary disputes continue, tiresome and childish troubles. The men much less capable of looking after themselves than I expected. Also though their minds are quick their attention has no stamina so that they misinterpret and misremember. Quick but shallow soil. On the whole they are happy men - the obverse of happiness being complacency they have little desire to change anything, much less themselves.

Have been reading diminutive magazines most of the afternoon. These concentrate on 'interest', catering for that extraordinary capacity of the modern reader for being interested in various information which he will almost immediately forget. So that indirectly they are an example of our rapid tendency to ennui and because of their transient character and their brevity they do not trouble about form: indeed as condensations while sometimes they perform a salutary compression they necessarily destroy the careful construction of a formally serious work. Finally they supply an illusive royal road, if not to learning, to the more tedious kinds of knowledge.

(Another air raid just over.)

Still I must confess that I can read the life of one outstanding trout with some interest.

Another thing that strikes me about these reviews is the immense faculty we possess for rereading the same things provided they have a different form: for their political

[20] articles with some exceptions are merely summaries of $\mid$ newspapers and so point to the fact that our increased consumption of news is compensated by an increased ability if not in digestion in excretion or forgetting. So I am forced to conclude that most reading is a habit like drinking or stimulation, holding by its power to divert attention from ourselves and make us forget our exposure to danger, humiliation etc even by telling us of these undergone by others. Ingenious device for an adaptable mechanism.

4 getting Anna] g etting Anaa TS 4 day - nothing in morning] day. Nothing in morning TS 5 w] with TS 9 men] mem TS 21 more] m re TS 25 we] they TS 27 newspapers] newspaper papers MS 30 reading] re ding TS 31 even] ev en TS 32 these] thos TS 1 Thurs $12^{\text {th }}$ Sept. Caring, Milgate ] Thurs 12th Sept. Carey, Milgate [(?Caring)] TS

2 probably in billets] That is, not in tents. 14 diminutive magazines] Elsewhere, Davin refers to reading the Reader's Digest, the New Statesman, and New Writing. The phrase is perhaps intended to refer to those like the New Statesman between 'little magazines' and mass-market ones. Alternatively, it refers to the dimished size of magazines due to paper rationing. 23 the life of one outstanding trout ] It is not clear to what Davin refers.

1 Thurs $12^{\text {th }}$ Sept. Caring, Milgate] The 23rd were billeted at Caring Farm, on Caring Lane. 


\section{Thurs $12^{\text {th }}$ Sept. Caring, Milgate}

Yesterday we shifted from our bivouacs to our 'billets' viz the barns, byres etc of a fruitfarm about 2 miles fr original position. My three sections are grouped about a yard, with the platoon HQ in a sort of old coach-house. Defensive $\operatorname{pos}^{\mathrm{n}}$ some distance 5 away and manned at stand-to.

The nearest shop and pub are two miles away, there is no leave for Maidstone and local leave is so brief and split that in view of the distance of the pub it is not much use. So it looks as if we are to have an extremely boring inexpensive time. The men are to be provided with some work in the orchards as a relief fr the drudgery of training but partly because of a shortage in rations today and partly because of their isolation they are grumbling a good deal. Coy $\mathrm{CO}$ has not improved matters $\mathrm{w}$ certain innovations which will restrict leisure still further. Affairs are under Coy so that we shall probably have a systematic syllabus w regular orders, wh is at least something. Invasion is now expected daily but as the men aren't to be officially informed of their role their discontent is more than they are really entitled to.

I myself have been working $\mathrm{v}$ hard and am dog-tired. I do not think I care for my Coy CO much. Small men tend to be either extremely good-tempered, turning their size into a comic asset or touchy and irritable compensating for what they lack in stature $\mathrm{w}$ what they can add in presumptions of dignity. I hope to get along with him well enough but I foresee certain stickiness if we are here for very long. Our men coming from the West Coast tend to imagine they are still backed by a union, have not reconciled themselves to the fact that there is a certain irreducible minimum of muddle, and discomfort in the army. One does what one can but it annoys me to hear more wrangling about food than is necessary. They argue for the sake of argument and

2 'billets'] billets TS 3 fruitfarm] fruit farm TS $3 \mathbf{3}^{2}$ ] two TS $\quad 3$ fr] from our TS 4 pos $^{\mathrm{n}}$ ] position TS $9 \mathrm{fr}$ ] from TS $\mathbf{1 3}$ wh] which TS $\mathbf{1 7}$ tend] [tend] TS

5 stand-to ] To stand in fighting positions ready for an attack; in the division, this occurred regularly at dawn and dusk, as well as when an attack was actually expected. This was intended partly as a defence as a surprise attack, but more often - as in this case - as a rehearsal to ensure that everyone knew their role and duties. See the long description of stand-to on Crete, p. 102.

14 Invasion is now expected daily] Writing on the same day, Brian Bassett, another officer in the battalion, explains that 'If the fight does not come in the next day or two it must be postponed over the winter. ${ }^{, 81}$

17 my Coy CO] This was Mark Harvey. The battalion's commander, Falconer, had been promoted to command the temporary formation of 7 Brigade on the $26^{\text {th }}$ of August. C
Company's once-and-future commander, Herbert Thomason, whom Davin normally refers to by this term, had been shifted in the ensuing reshuffle to command HQ Company. ${ }^{82}$ After other rearrangements, he would return with Falconer on the $7^{\text {th }}$ of March 1941. 21 coming from the West Coast ] That is, being predominantly unionised mineworkers rather than farmers or city men. The 23rd's official history states: 'Nearly all walks of life were represented, and if miners predominated in C Company [Davin's company] and farmers and farmhands in $\mathrm{B}$, this factor accounted for the physical prowess displayed by these two companies on rugby as well as battle fields. ${ }^{83}$ cf For the Rest of Our Lives, where 'His men were West-Coasters, miners mostly, and he from the South. ${ }^{84}$ 
they sound as if each one was a triplet, and there had been breasts only for the two most vociferous.

What I am to do about Winnie and Anna I cannot yet decide. An opportunity may

[21] present itself to bring them here but pro incerta re I can do nothing meanwhile. | Air raids continue daily and we have found many scars of abortive incendiaries.

My sergeant is honourable, efficient, able and like many able men in inferior office slightly tactless: he hasn't yet quite realised the art of talking by silence, conveying opinion by reticence and implications by reservations. My new batman is red-haired, a little raw, a lot to learn, even-tempered not a fool, willing, young, robust and incapable of believing a British plane can be brought down unless he can finger the wreckage. Incredulity is then succeeded by indignation at 'those fucking Germans'. He is sentimental, feels a great disgust for the 'morals' of London women i.e. whores; as well as a healthy interest in them. His mother wishes he were home again even if he did in his rage throw a plate of pudding on the floor. Air raids send him half-crazy w excitement, though here he is no exception.

It is suggested that the frequency of AWL is due to the fact that many of those men were paid in NZ for the amt of work done and stopped or started as they felt inclined.

I am now making some attempt to teach my corporals responsibility but it is not easy. They find it hard to sacrifice comradely equality for authority and responsibility and they do not realise altogether that a more successful compromise than their present is possible. They find it hard to give crisp orders and make the mistake of arguing when the time for discussion is over.

\section{Tuesday $17^{\text {th }}$ Sept.}

On Friday I was suddenly given the job of going to Mytchett $w$ the padre and collecting washing and belongings left there. Leapt at the chance as it was an opportunity to spend the night w Winnie and Anna. Fearful load of commissions, many imposs.: e.g. "please collect pair of battle-dress trousers from policeman on crossing before

1-2 two most vociferous] most vociferous TS 9 learn] lea n TS $\mathbf{1 1}$ is then succeeded] is succeeded TS 11 at] what MS 16 those men] these TS $18 \mathrm{Iam}$ ] Iam TS 18 teach] [teach] TS $2317^{\text {th }}$ ] 17th TS

4 pro incerta re ] for something unsure.

6 My sergeant] Charles Horace Dutton (1913-1992) Davin's sergeant, a butcher and smallholder from Motueka. When Davin was shifted to become IO, he took command of the platoon. ${ }^{85} \mathrm{He}$ was wounded in Crete and taken prisoner.

8 My new batman ] Stanley Clarence 'Ginger' Evans (1919-?) Davin's batman, a young miner from Cobden, near Greymouth. He would spend the next three years with Davin whenever Davin was on active service, until he married on furlough in 1944 and did not

return. $^{86}$

8 batman ] A soldier assigned to an officer to act as a combination of servant, valet, runner and driver.

10 unless he can finger the wreckage ] Perhaps a reference to the apostle Thomas, who would not believe unless he could finger Christ's wounds.

16 AWL ] Absent Without Leave. 24-25 collecting washing and belongings left there ] 'Unnecessary gear' had been left or sent to Mytchett to avoid encumbering the battalion in an invasion. ${ }^{87}$ 
camp. Perhaps his name was Fraser." "Please collect washing from red-haired girl". One washer-woman was deaf and excitable and given to muttering "Poor troops! Poor boys!" as she scurried from place to place. Poor troops indeed, their belongings piled indiscriminately in one tent, boots in plates, socks in mugs, everything in a mess. An exasperating, hopeless task.

The officers in Mytchett all concerned $w$ the vast impossibilities of making a dozen guards half of them blind, halt and lame, the other half natural scoundrels, do the work of twenty; making rations for a dozen do for another dozen unheralded and unsupplied. Etc etc. | But had a few beers, the first for a week, w Winnie and Norman Noakes at The Angler's Rest and a lovely night at home. A rush trip full of petty commissions w Winnie to Aldershot and thence w two time-bomb deviations back to Mytchett here . Then orderly officer and the following day. Re

Reconnaissance trip on Sunday to area betw Dover and Deal, bad meal in Maidstone. Country looking beautiful, towns unprepossessing. Air raids constantly and a bomb not far away. Skies full of drama, played behind the clouds.

Yesterday again to operation area, this time $\mathrm{w}$ troops. Tedious day as reserve battalion. Lost map and Chekhov's Short Stories in bus. Had just read 'the Party' again. Excellent.

Very angry this evening $\mathrm{w}$ the men for laziness in stand-to. They seem to have no gift of pretending or make-believe, though the Tommies for some reason excel in it. The Tommies excel them also in patience $\mathrm{w}$ the tedious waiting and seeming purposelessness of these preparatory manoeuvres.

Orderly officer again today and so have an opportunity to answer the letters which are beginning to accumulate on me. One from home: all well but worried. Afraid my mother will not survive many more winters.

High winds yesterday and today will make invasion even more difficult. Very circumstantial account of German attempt and failure denied by War Office after gaining wide circulation in these parts.

4 one] the TS 6 impossibilities ] impossibilties TS 8 making] and making TS 9 Etc etc.] Etc. Etc. TS $10 \mathrm{w}$ ] to TS $\mathbf{1 1}$ to Mytchett here ] here TS $\mathbf{1 2}$ day. Re] day. TS $\mathbf{1 3}$ betw] between TS 13-14 Maidstone] Maistone TS 17 Short Stories ] short stories TS 20 make-believe] make-beieve TS 20 excel] ecel TS 21 them also] them TS 23 answer] consider TS 25 survive] survibe TS

9 Norman Noakes] Norman de Berri Noakes (1908-1977) A dentist from Auckland; he had been Geoffrey Cox's roommate at Otago University. ${ }^{88}$

10 The Angler's Rest ] A pub on Frimley Road, just outside of Mytchett.

11 time-bomb deviations ] Diversions around unexploded bombs. Some bombs were designed to penetrate buildings before detonation or to interfere with rescue efforts; these had a fuse set to go off at some fixed time after impact. In other cases bombs merely failed to explode.

12 orderly officer] Officer in charge of administration of a unit for a period; duties included inspecting the guard and meals. 17 in bus ] The New Zealanders had been equipped with a fleet of London buses 'complete with Cockney drivers' to enable them to act as a mobile reserve. ${ }^{89}$ 20 Tommies ] English soldiers. 24-25 my mother ] Mary Magdalene Davin (1878-1944) 
Stung by a wasp this morning without provocation. Retaliated with a punitive expedition costing many lives. 'Dive-bombers' the boys call them.

Scarcely any chance to read or write these shortening days. Can't use a light because no fourth wall. Hope to get a chance this afternoon. Now close to lunch time with a big wind blowing. Several of the men down with a mild dysentery.

$18^{\text {th }}$ Sept.

A dreary day of odds and ends of jobs. The last couple of days have been descending into a deep depression: too close confinement to the place is getting on my nerves: rumours of return to Mytchett, $48 \mathrm{hrs}$ leave and departure for Egypt. But more likely to remain till invasion threat over. The men have been annoying lately with their constant grousing and almost childish helplessness. Bombing raids have been getting closer lately. Planes fly very high and look like curious celestial fish.

Am half through a shift of HQ to present Coy HQ, an old oast-house. Pleasant change if managed but as usual accompanied with the most irritating confusions and delays. Result that I am writing in the middle of the babble of my men who have already shifted into my quarters.

Had a bath today in the house of a young widow, a discovery of Captain Harvey's. Haven't seen the widow however.

Trying to get Ashby transferred to HQ as driver. A sullen, lazy fellow but with more potentialities than most of them. Obviously discontented as a plain infantryman and so may improve if he gets a job he likes better.

Kit inspection this morning. Some of the men have a flair for tidiness. Most of them are middling; but a few have an almost natural addiction to squalor.

If the army teaches a man anything it should be a sense of order and neatness. Yet remember the story of Jack McPherson in Invercargill. Returning from the war with a habit of early rising he estranged himself from a more indolent wife, began to sleep in a hut of his own at the end of the garden and in the end scarcely saw his wife at all. Not that that was the whole of the story, I suppose. But might make something of it sometime.

4 to lunch time ] o lunch t ime TS $618^{\text {th }}$ Sept.] 18th Sept. TS 10 annoying] ann ying TS 12 look] lokk TS 12 curious] curios TS 21 potentialities] porentialities TS 26 Jack] Jacj TS

14 Am half through ] This page of the typescript is headed: 'DIARY: 1940 (Copying resumed 28 May 1977.' [sic] 14 oast-house ] A building for drying hops. 20 Ashby] Alexander Quin Ashby (1918-1984) A private in Davin's platoon, a truckdriver from the West Coast. 26 Jack McPherson ] Not identified. No variant of Davin's anecdote has been found in another source, and no First World War veteran with a variant of the name had a wife as next-of-kin in Invercargill on enlistment. However, two different First World War veterans named John MacPherson (John MacPherson, 1880-1956, and John Gordon Stewart MacPherson, 1897-1986) married in Invercargill, in 1920 and 1919 respectively. The latter was known as Jack MacPherson ${ }^{90}$ and was 'well-known both in Invercargill and in Lumsden' by that name. ${ }^{91}$ 
Must try and get Peckham back his stripe. An able fellow but lazy and shunning responsibility. Yet a natural leader. Might be either a gang boss or a good foreman at his present stage. have Should be made into the latter.

\section{Friday Sept $20^{\text {th }}$.}

Yesterday gloom deepened. Was Bn orderly officer in the morning, a wholly pointless job which by lunchtime was abolished, not wholly unaided by my denunciation of it. Borrowed Vol 1 of Dreiser's Gallery of Women and Vol 1 of Hardy's Tess. Also a New Statesman. The latter gives me great pleasure now: it seems to echo the conversations and renew faintly the atmospheres of the year ago that is now an age. The Dreiser is much more readable than I had expected, though the indirect narration is often clumsy 'so she said she said'; but the character of the impartial listener is well implied. Reminds me of Waugh, Gerhardi and Isherwood: the earlier forms of their principal character, whose chief quality seems to be a sympathetic neutrality and bottomless capacity for confidences. Must write something about these people some day.

Of course these 'varialistic' women of Dreiser's interest me because they interest me in life also. Whether because they are good hunting? I don't know and in any case it is many a day since I did any hunting. Dreiser occasionally says a very good thing too: good in substance.

Last night feeling desperately dreary sought out boozing pals. But they had all for one reason or another given it up temporarily: partly because they wanted to go on a night hunting patrol. It sounded romantic but ended as I suspected it would in tedious lying among nettles. | Going up the road met a man wife and dog. Dropped wife and dog and man drove me to the pub. Pub frequented by Englishmen of the saloon bar type: ambitious young businessmen. Crippled by snobberies and inhibitions: all wore pseudo old school ties of one type or another: all accents were in the transitional stage.

$42^{\text {th }}$.] 20th. TS 9 now] [now] TS 12 :] $:$ TS 13 chief] chief TS 16 know] kinow TS 17 is many] ismany TS 20 they] the TS 21 suspected it would] suspected TS 24 :] and TS

1 Peckham ] Edgar George Ashby Peckham (1917-2000) Soldier in Davin's platoon, from Wairoa. A sergeant when he left New Zealand, he was a private when first encountered. But he fulfilled Davin's prediction. He was first promoted to corporal on 7 May 1941, and then was a sergeant again by the time he was wounded and captured on Crete. ${ }^{92}$

9 the year ago that is now an age ] i.e. pre-war. 12 Gerhardi] William Alexander Gerhardi (1895-1977) A critically-acclaimed novelist of the 1920s. Frank Fahey reads him in For the Rest of our Lives ${ }^{93}$ Olivia Manning claimed to have had an affair with him. ${ }^{94}$ In later life, he went by the name Gerhardie.
15 'varialistic'] Not a word used by Dreiser, and one unknown to the $O E D$.

$\mathbf{1 7}$ it is many a day since I did any hunting. ] See Northrop Frye's description of his first meeting with Davin (8 December 1936): 'The Balliol New Zealander was a good head [...] He had only one idea at that time - to rush down to London and find a woman. He's probably happy now [...] The New Zealander said if he didn't find any women in Oxford he'd bring his fiancée over. I didn't ask him what his fiancée's point of view would be. ${ }^{35}$ (Davin's diary notes this meeting as six days earlier, in the Eastgate Tavern; he records only that they 'discoursed lengthily. ${ }^{96}$ ) 
The accents represented the men. Yet not bad fellows though they represent the biggest handicap to social progress this country has. Men I would go miles to avoid usually but interesting enough regarded as a study. I suppose in some respect or another they are not humdrum yet how isolated they are from one another, islanded by a taboos against thinking and originality, caught between two classes, and yet unable to look forward to classlessness.

Today went to tank demonstration and later to AA ditto. Passed W.W. at the head of his platoon. Suddenly I realised I was jealous of this man. What on earth for, I wonder? I despise his type, their bluff, sentimentality, lack of any of the integrities I admire. Well I suppose I shall find out what it is.

Could go out tonight but nobody to go with, though half inclined to go. Am very restless and depressed. Badly in need of some adventure. But I belong only to the middling adventurous, have not my full share of that magnetic attraction some have for adventure. I accept the odd when it comes. But I seldom create it, as it were. Hear rumours that I may get a job of a new kind soon. Possibly connected with languages. Doubt myself here as I am not a natural linguist. My ears aren't subtle enough in spite of a flair for translation.

Trying to find a way back to Mytchett and Winnie but can think of none.

Have shifted HQ to a stonepaved room next to a stable. It has a desk and I have privacy. I have also that tormenting conflict between the urge to write and the reluctance. My mind has been so much away from the writing of definite things though often with the vague urge itself to write that my mind holds no definite skeleton which I might clothe with words. I have the emotion but no single thought for its nucleus. But I have a candle. It seems to me that one might almost classify literature into periods governed by the prevailing lighting system. The hardness might go out of our writing if we could sacrifice electricity.

6 classlessness.] classlessness.. TS 15 that ] hat TS 18 think] thnk TS 19 stonepaved] stonepaved TS 22 holds] has TS 22 skeleton] skel eton TS 25 system. The] syst m. Th TS $123^{\text {rd }}$ ] 23rd TS

7 Today went to tank demonstration ] This was probably conducted by Tom Wintringham, of Spanish Civil War fame. ${ }^{97}$

7 AA] Anti-Aircraft.

7 W.W.] Keith Campbell West-Watson (1914-2003) Officer in 21 Battalion who also enlisted in England. He was the son of Campbell West-Watson, Anglican Archbishop of New Zealand.

Davin may have been introduced to him by Peter Norris, another subaltern. Norris was the son of an Anglican priest from Canterbury and wrote to his mother about seeing West-Watson at this time. ${ }^{98}$

It is equally possible that there was some connection to West-Watson's sister Alison. She had studied English at Canterbury, where she was friends with Ian Milner, ${ }^{99}$ but then like Davin went on to Oxford, graduating in 1935. She remained there and married an Englishman. ${ }^{100}$ But she had evidently delayed long enough to interfere in Barbara Pym's love-life and earn a starring role as Agatha in Some Tame Gazelle. ${ }^{101}$

Keith West-Watson studied at Canterbury and at Emmanuel College, Cambridge. In the brief time before the war, he was involved in theatre in England while working as a schoolteacher. After it, he returned to New Zealand after an attempt at a career as a screenwriter for Gainsborough Pictures and at running a school in the Sudan.

He also wrote several books under the pseudonym Keith Campbell. 


\section{Monday Sept $23^{\text {rd }}$.}

On Saturday attended two demonstrations: A.T. and artillery. Later visited D Coy on way to Maidstone. Persuaded to visit old bomb-hole from night before. More than $20 \mathrm{ft}$ deep with huge stones cast a gt. distance. Fortunately fell in a middle of 5 stubblefield and caused no casualties. Persuaded to stay and eat with Cunningham, Bond and Ensor: stew and sago all for lunch to my gt disgust. Later walked to the Plantation. Had a good deal and went to somebody's for supper, fell asleep and thus home.

Sunday: tookchurch parade of RCs. Men sat or knelt on old chicken coops. Not unmoving spectacle though to me so only by association or reminiscence. Afternoon spent reading sleeping. Evening visited Plantation again with Connoly, | Thompson

2 demonstrations] demonstration TS 3 from] frm TS 4 gt.] great TS 4 of] of a TS 6 Ensor: stew and sago all for lunch to my gt disgust. Later] Ensor. Later TS 9 Sunday: took] Sunday. Took TS 10 unmoving] unmovong TS

2 A.T.] Anti-Tank.

5 Cunningham ] Gordon Hallum 'Ginger' Cunningham (1910-1984) A stock agent from Central Otago who had studied commerce at Otago University. He commanded 18 Platoon, D Company. A 'wee fat man with ginger hair', said an unsigned list of descriptions of officers in the early days of the battalion. ${ }^{102}$

His second wound, received from artillery fire while he was adjutant of the battalion, sent him home.

6 Bond ] Robert Louis 'Bruff' Bond (1908-1965) Adelaide brewer commanding 16 Platoon, D Company. His health broke down after Crete and he returned to New Zealand because of his "acking corf ${ }^{103}$ or 'because of his asthma. ${ }^{104}$ He nonetheless joined the Australian army in 1942.

6 Ensor ] James Hugh 'Jim' Ensor (1908-1979) A farm manager from Cheviot commanding the sappers of 23 Battalion. 6-7 the Plantation ] The Old Plantation Inn, a pub on Plantation Lane in Bearsted.

9 church parade] Compulsory religious service.

10 though to me so only by association or reminiscence] Ovenden dates Davin's withdrawal from the Church, precipitated by the Spanish Civil War, as 'some time between the Septembers of 1936 and 1939. ${ }^{.105}$ In the early days of the war Catholic church parades were not compulsory, ${ }^{106}$ but Davin gave his religious affiliation to the Army as Roman Catholic and Bassett describes Davin as 'our only R.C. officer.' ${ }^{107}$ This would make his attendance obligatory, since every church parade needed an officer.

11-1 Connoly, | Thompson and Richards. ] The new page of the typescript has the marginal note 'Copy resumed 8 Oct 77 '; the text continues under the heading ' 23 Sep 40 contd)'.

11 Connoly] Joseph Richard John 'Dick' Connolly (1910-1980) A petrol serviceman in civilian life, although he seems to have given other officers the impression that he was a motor oils salesman. A subaltern with 23 Battalion from the beginning (in command of 17 Platoon, D Company), he rose to command it in 1943, interrupted by furlough, until his legs were broken in a car accident. 'But if you are tempted, as I am, to think that Connolly was the personification of 23 , you are near what I am getting at. A man's man, a born leader, and an officer only as a last resort. ${ }^{108} \mathrm{He}$ retired to Christchurch. ${ }^{109}$

11 Thompson ] Frederick Sleigh Roberts 'Ted' Thomson (1912-1943) A rugby forward who had played for the South Island; he was a draper from Timaru. Davin replaced him in C Company when he was moved to form a tank-hunting platoon. He was killed when his vehicle was strafed in the desert. 
and Richards. Pleasant evening and thus home via HQ Company and a wetting in the brook.

Monday: Out in Div Manoeuvres. Exhilarating day charging thro bush and hedges marred at end by muddle in embussment. Tempers running high in Coy HQ. C.O. irritating and testy and quick to find loopholes when committed, 2 i.c, honest and straightforward but unsubtle. Criticism of smelly stew immediately accepted as personal criticism. Almost quarreled w me, therefore: largely to vent irritation roused elsewhere. Very silly that men engaged on jobs where co-operation essential shd not be able to hide their differences better. English manage it better because of the habit of politeness. NZ terrified always of the accusation of servility confuse tact with obsequiousness.

On the road in the bus the Kentish farms looked wonderful with the corn motif softened by distance and predominant. Stacks, oasthouse, even rooftops fitted into it and over all the vast circle of the sky. From a hill the little groups of buildings get their beauty largely from their being each an individual organism and the buildings in each merge perfectly into the harmony of the whole. This is the skeleton behind it and over this is laid the colour pattern, to please the eye as the unity of particulars pleases the mind. And this is probably the simplest xplanation of that perplexing problem: something which pleases the senses and the mind together. So the harmony of one unity raises sympathy in another sentient unity.

This morning fiddling about fatigues and watching air-raids. A letter from Geoffrey deploring the Deirdre Ard Ri reason against betrothal to Anna as being outweighed by the fact that we are already at war. A charming letter.

The sun is coming up through the hedge to make a graceful day.

Several of my men who are all West Coasters know my brother Martin: a man apparently famed there for doughtiness in diverse argument.

12 Richards.] Richards.. TS $\mathbf{1 4}$ Monday:] Monday. TS $\mathbf{1 7}$ immediately] immedi ately TS $\mathbf{1 8}$ Almost] Amost TS $18 \mathrm{w}$ ] with TS 19 co-operation] cooperation TS 23 the Kentish] theKentish TS 23 with] wit TS 23 corn] corn[(?] TS 25 over all] overall TS 29 xplanation] explanation TS 35 graceful] grateful TS 36 a man] aman TS

12 Richards ] Edwin Ernest 'Ted' Richards (1915-1962) A civil servant in the Lands and Deeds Department, Nelson who was mortar officer in 23 Battalion. He was transferred to 26 Battalion and became its second in command and then its commander.

15 embussment ] Boarding transport. 32 Geoffrey] Geoffrey Flavell (1913-1994) A friend of Davin's from Otago. After being caught up in the same scandal that at first cost Davin his Rhodes, he moved to England to continue his medical studies. He graduated from St. Bartholomew's hospital and became a well-known thoracic surgeon.
33 the Deirdre Ard Ri reason ] 'Deirdre of the High King'. Flavell is referring to Deirdre, one of the most famous figures in Irish myth. At Deirdre's birth, it was prophesied that she would grow up so beautiful that war would be fought over her. Instead of having her killed at birth, Conchobar mac Nessa, the King of Ulster, decided to keep her alive to marry her, with terrible consquences. Flavell's dark joke is that because the war is already happening, marriage would have no consequences. 36 Martin ] Martin 'Matt' Davin (1914-1995) Davin's younger brother. 
I found these quotations in a New Statesman the other day.

Sois sage, O ma Douleur, et tiens toi plus tranquille.

Tu réclamais le soir; il descend; le voici.

Quoted by G.W. Stonier.

So here I am, in the middle way, having had twenty years -

Twenty years largely wasted, the years of the l'entre deux guerres -

Trying to learn to use words, and every attempt

Is a wholly new start, and a difft kind of failure,

Because one has only learnt to get the better of words

For the things one no longer has to say, or the way in which

One is no longer disposed to say it ...

$\mid \ldots .$. . And what there is to conquer

By strength and submission, has already been discovered

Once or twice, or several times, by men whom one cannot hope

To emulate - but there is no competition -

There is only the fight to recover what has been lost.

Have refound my Penguin volume of Tchekhov. The stories are as good and moving as ever they were. But cannot find my odd volume of Hardy's Tess.

Another alarm now and the fight begins overhead.

A lovely letter from Winnie the other day which I must answer. She is telling Anna the story of my life, she says, but cannot remember much of it. How it pleases me that she should love Anna so much. It is one of the few things I have given her, and then characteristically she had to suffer to have it. Dreamt last night of Anna but was interrupted by a rival dream that a wasp had come under the bedclothes and was about to sting me on the spine.

Have come to think a lot about Oxford lately and the better days there.

\section{$27^{\text {th }}$ Sept. Sat Fri.}

1 quotations ] quoatations TS $\mathbf{1}$ the other day.] the other day. [Quoted by Stonier] TS 3 réclamais] reclamais TS 7 l'entre] L8entre TS 8 words, ] words. TS 9 difft] different TS $\mathbf{1 7}$ to recover] torecover TS 19 they were] theywere TS $\mathbf{2 3}$ she] she TS $\mathbf{2 4}$ to] t TS $\mathbf{2 4}$ have] hve TS $\mathbf{2 8}$ $\left.27^{\text {th }}\right] 27_{\text {th }}$ TS

1 found these quotations... the other day ] Davin is quoting from a review in the New Statesman of 14 September 1940 , by the magazine's literary editor, G.W. Stonier. ${ }^{110}$ The quotation from Baudelaire concludes the review. It is comprised of the first two lines of
'Recuillement'. Geoffrey Wagner's translation is ' $\mathrm{Be}$ wise, $\mathrm{O}$ my Sorrow, be calmer. / You implored the evening; it falls; here it is:' 4 Quoted by G.W. Stonier.] This paragraph is not present in the typescript. 5 T.S. Eliot's latest ] East Coker. 
Most of the coy away on games. My platoon shifting billets into an old stable, reluctantly at first but with enthusiasm as by a little work the position improves. Expect to shift myself in a day or so but probably manoeuvre tomorrow first. Bought a little electric lamp today - probably not much good but looks well. Heavy air raid this morning and another on now: but nothing very spectacular so far.

Had a few beers last night but awoke feeling very depressed. If only I knew how long we were staying and cd get Winnie down.

\section{Thurs $4^{\text {th }}$ October:}

Seemed to have neglected this lately for no particular reason. Busy with trifles, I suppose. But tonight as I am commanded to go to the pub on the occasion of Major Fyfe's birthday and don't want to drink too much I might as well write a little before leaving.

On Sunday we went to the coast on manoeuvres and had the usual comedy of errors, making on the whole a satisfactory day. Yesterday of course the area was shelled.

Yesterday morning an opportunity of going to Mytchett presented itself. Rex King had to take a truck. He soon dislodged the over-cautious driver and we got there in record and exciting time. Apparently reckless driving but really through a footballer's sense of timimg pretty safe and not boring as a slow trip would have been.

Found Winnie and Anna looking wonderfully well and had a beautiful day, culminating in one of our nicest talks at the Angler's Rest. Gave Winnie a pound, one of my rare poor presents to her. Even then she'll go and buy the wool for my gloves with it. At one stage a 'spat' as Guy wd have called it threatened to destroy our day. I suppose I was jealous of the time and attention spent on Anna detracting from my urgency, and Winnie was jealous of my not having seeming interested enough, yet prolonging the performance so that I should be persuasive, a delicacy I'm afraid my impatience

[27] made me overlook. Then the / awful vacuum of resentful interlude, when one sits with cigarette marshalling one's nerves for the inevitable explanations and apologies, the

1 of the ] ofthe TS 3 to shift] toshift TS 3 probably] p robably TS 5 morning and another ] morning, another TS 5 now:] now; TS $7 \mathrm{~cd}$ ] could TS 8 Thurs $4^{\text {th }}$ October:] Thurs. 4th October. TS $22 \mathrm{wd}$ ] would TS 24 interested] i teres ted TS 26 awful vacuum] vacuum TS

10-11 Major Fyfe ] Thomas 'Tommy' Fyfe (1892-1941) A veteran of the First World War commanding HQ Company, and second-in-command of 23 Battalion as a whole in Crete. A schoolteacher from Gore.

15 Rex King] Rex Keith King (1909-1980) A Christchurch schoolteacher who became a subaltern in C Company alongside Davin. He was captaining a NZ rugby league team touring England when war broke out.

22 Guy] Guy Theodore Nunn (1915-1984) According to Northrop Frye: 'you'll hear more about him. Merton, Dan Devon's [sic] room-mate, American, with Trotskyist leanings. ${ }^{\text {'11 }}$

In 1939 he went to Prague posing as an art dealer to rescue thirty-six refugees. $\mathrm{He}$ parachuted into Hungary in 1944 and was imprisoned in Colditz after deliberately being taken prisoner in order to serve as a secret negotiator for the OSS.

He was later prominent as chief of the radio and television department of the United Auto Workers of America at the time of their greatest power.

. 
weary burden of reconciliation, the careful skirting of pitfalls, plunging one back into the black mood from which with time and toil one has ascended. The sense of futility in such moments when one can see nothing but the meaningless repetitiveness of it all. For when desire is momentarily murdered reason does not hesitate to revile its corpse.

5 Then the new surge of blood, passion and its slaking, hope and the peace that follows, happiness and fulfilment and the renewal of meaning.

A wild drive back through the night on unfamiliar roads, with police and wardens for enemies (inimici) and the German bombers for fate and the wider hostility (hostes). And then to bed.

This morning idleness, nominally preparation of a lecture. I really think the atmosphere of the mess is becoming less strained, and I think I am the emollient. This afternoon a route march, during which I evolved a scheme for a lecture on government: a sort of popularised progress from Plato to Hitler: how strange the conjunctions that the associative reason can produce: the genius of the mind's solvency and the genius of its bankruptcy. The patient reducer of unrelated strands to a rope up which the mind can climb, the demonic grasper of strands pellmell to weave the rope for humanity to hang itself. Fortunately the latest rope will be hardly likely to take the weight.

\section{Tuesday Oct 8}

German and Italian troops have occupied Rumania, achieving the familiar climax.

Spent Sunday in Maidstone. Met WW, his mistress and her husband. Was very popular with all three, being used by WW and wife to keep husband busy, and being regarded fairly favourably by him as a conversationalist. Met also another similar triangle and so spent the day observing these two situations and drinking a good deal. In each case I liked the husband and was not very taken with the wives. Sophisticated and cool as these middle-aged English wives are there is something diabolic about the ruthlessness [(with which)] they pursue their love: no apparent scruples other than expediency and a certain unflashing of the teeth which is almost frightening. In

2 the ] th TS 2 ascended] asc nded TS 7 through] thrugh TS 8 fate] fat TS 10 really] rea ly TS 11 is ] i TS 15 up] iup TS 16 pellmell] pellmell[(?)] TS 22 conversationalist] conversati nalist TS 24 each case I] I case I MS 24 the] th TS 26 ruthlessness [(with which)] ] ruthlessness MS 26 they] they TS

7-8 with police... hostility (hostes)] The joke here is a subtle difference in translation: hostes being foes and inimici enemies, but either word roughly interchangeable. The distinction is between the private enemy, the traffic police, who act like pirates as representatives of themselves and enemies of all (inimici), and the public enemy (hostes), the German opponents equivalent to privateers who are representatives of a commonweal and thus enemies only of some. In short, not as bad. The distinction comes from international law. Davin may have picked the terms up from there in the fervid atmosphere of the thirties. Alternatively, Aquinas uses the words but not the precise meanings in his discussion of a just war. 11-13 This afternoon... Plato to Hitler] See Davin's October 11 discussion of the lecture presumably developed from this, p. 15. 19 German and Italian troops have occupied Rumania, achieving the familiar climax. ] German troops occupied the Romanian oil fields on the eighth of October, rather than the whole of Romania. ${ }^{112}$ 
youth these things are veiled with blushes and general approval. The world loves a young lover. But later the hunger fighting its way through obscurities of deceit and manners is naked and unashamed. The mask is over a naked body, the lust is plain to see and sentiment is merely a tacitly accepted code. cf. Mrs S. These women frighten me, the Potiphar's wives, Roman Empire women. But the paradox makes fascinating observation, the blasé langour and indifference of the surface against calculating yet devouring sensuality: like the snake concealed beneath the impassive stone. And always I get the feeling that the men are mere symbols, accidental instruments. Somehow when one man causes the dishonouring of another however unthinkingly he is himself

[28] dishonoured and the woman becomes dominant. It is male possession which is $\mid$ flouted and each man therefore shares: the fate of the one man menaces his successors.

On Saturday we did another scheme, somewhat tediously. Today I am alone with the coy giving those who are not playing nominal supervision and doing German. Things continue to improve in the mess and I have discovered in King the natural storyteller: having that peculiar quality not of the story but of the teller which brings laughter before even the joke is told. A strange mixture of cunning and honesty.

\section{Fri Oct $11^{\text {th }}$}

We are going to Camberley and billets in a few days. I shall be glad to get back where I can see a little family life again and have Winnie to talk to. There is no one here to whom I can talk without reservation as an equal.

Yesterday gave a lecture - a sketch of the origins of totalitarianism. God knows it was poor stuff as I well knew before I gave it. But I had no books, only a memory weak in itself and resentful of the little trust that has been placed in it. But the experiment was a great success. I did not overrate them after all. They want more. But I cannot give them much more without uncovering my real opinions. And this is not Oxford where an opinion is entitled to exist because it is an opinion. Superior officers come from NZ's most narrow and complacent type. My interest advises caution. So I shall survey the ground and perhaps return again. The trouble is that when I begin to write or speak honesty breaks in. I was quite impressed by my own sincerity and I think that is what held them. NZers don't readily warm to me but they find it hard to avoid respecting me if I set out to make them. But what a problem there is here: is it possible to break them away from their petty certainties and partisanship and free the energies they all have? If one could harness their vitality to their minds one could set up a pretty pace.

6 blasé ] blase TS 7 stone] ston e TS 9 another] anothe TS 10 male] male TS 13 playing] laying TS 13 German ] german TS $171^{\text {th }}$ ] 11 th TS 19 noone] noone MS 23 in it] it in it TS 24 great ] gret TS 24-25 cannot give them much more] can't give them much TS

4 Mrs S.] Probably Mrs. Simpson, the divorced American whose ineligibility to marry Edward VIII led to his abdication. But Davin noted his support in his Oxford diary for 'the only king who ever treated a woman decently' when Edward announced his abdication. ${ }^{113}$

\author{
5 the Potiphar's wives, Roman Empire \\ women. ] Potiphar's wife attempts to seduce \\ Joseph and is rebuffed in Genesis 39. 'Roman \\ Empire women' is a reference to the stories of \\ destructive female desire in historians of the \\ Roman empire.
}


Last night saw the Grapes of Wrath. Very good though it lost the splendid prose. Even in myself who knew what was to come and am not much afraid of gloom, tending to expect calamity as more natural than good fortune, there arose the impulse to go, to escape the strain imposed by the long portrayal of their wandering doom. Harder 5 perhaps for me than for some of those who left since I believe that these things are true and terrible and not merely boring. And again I felt that somehow I am missing my road, am looking in shop windows and mirrors while outside my own people are fighting in the street. It is not enough to wait for circumstance to present one with alternatives where honesty can admit of only one course: one should make not merely the decision of integrity but the situation which compels the choice. And yet I shall not, I know. Only if fate pushes me from behind shall I ever be committed to heroically unselfish action.

This morning went to Gore Court with a party of men to shovel coal for the A.T.S. How wonderfully smooth in action are these men, on the parade ground so / careless, in the work they know. And there was one pretty little AT who made me know how deeply already I am compromised with life. That to gain the ste intense domestic channel of a home, I must withdraw the wandering stream. Ulysses and Penelope. Shocking that the attraction of a casual backside should bring me so sadly to the limitation and the grotesque tragedy of conflicting desire. Vanity behind it all: sex has its Alexanders no less than war, and Caesar was a Caesar to others than the Gauls. Even he a bald-headed Romeo.

Today is the quintessence of an autumn day, bright sun and the chill frost creeping towards its mastery. The gold gains daily in the trees and the singing birds are so sweet that one would think they were trying to cram the utmost burden of their ecstasy into the remaining hours.

Sat. Oct. $12^{\text {th }}$.

It is 10 p.m. and I am sitting up in my room officer on duty and on call. News has come through that the Germans are feverishly preparing to invade. The full moon, clear frosty night and a calm sea favour the attempt. And if an equilibrium of air losses 10 decision ] ecision TS 11 know. Only] know,only TS 13 A.T.S ] ATS TS 21 Romeo.] Romeo, TS $2612^{\text {th }}$ ] 12th TS 28 preparing] prepa ing TS

1 Grapes of Wrath] The 1940 film of the novel, starring Henry Fonda.

13 Gore Court ] Gore Court was a country house near Sittingbourne, Kent. It was demolished in the 1920s, and part of its land was transformed into a public park. The ATS Auxiliary Territorial Service, the women's branch of the British army - may have been camped there or in a military hospital which was established in the grounds. However, it is more likely - because of the need for coal that they were established in Gore Court
School nearby, another former country house. 14 careless ] In the far right corner of the typescript page is typed '(16 Oct. 77 ' [sic]. 18 the attraction of a casual backside ] Richard Cobb wrote of 'the often agreeably close embrace of [ATS] skirts. ${ }^{114}$

29-1 an equilibrium... attack may be likely ] A letter to Winnie a few days later gave a different interpretation: 'We are all fairly convinced that it is mere bluff to hold troops in England and cover operations in the South East but nonetheless we've got to stick here. ${ }^{115}$ 
30

sound as it seems the attack may be likely. So perhaps this is our last evening of comparative peace. Rather disconcerting since I had almost forgotten there was a war, air raids being so impersonal, and have been looking forward incautiously to a quiet winter seeing much of Winnie and Anna. And if it comes it will find me in a job which does not utilise my real capacities.

Last night went to a dance in Maidstone - danced twice and was excused by a raddled harridan. Even the compliment of her interest could not redeem her repulsiveness. And having to fight six deep to the bar for a drink. Once there I stayed there listening to the somewhat sentimental rhapsodising of Les Greig on the beauties of my character, alcohol induced.

I met one of those dance-mad blondes, captivated no doubt by my rudeness, who drove me home to supper with her landlady's son and daughter. Son was a naive embryo architect. In bitter volubility I denounced everything in a most unEnglish but quite entertaining (to an Engl appreciative audience of one - myself) manner. Thus recovering my good humour and becoming well-fed I got a lift home in a postal van the crowd had precisely the same effect on me as long ago when as a boy at home I attended dances and felt lost and alien. It seems that the ugly duckling has not yet become a swan - not in some ponds at least.

Today spent largely at a court of inquiry. Although having no interest in what happened to Private X's pants I enjoyed the cross-examination which lapsed almost immediately to me and realised that I could probably be quite a good criminal lawyer. Could have been.

\section{Thursday Oct $17^{\text {th }}$.}

Today we went on a 20 mile route march. Much disheartened by my men's perfor55 mance. Definitely the worst in the battalion for falling out. Had been / in the Royal Star till late drinking beer myself and then walked four miles home, had blistered feet when march began but did not find it very tough. So very disappointed in the men.

Met Thorpe Harrison in Maidstone: in Royal West Kents and somewhat disgruntled because not yet sent to an O.C.T.U. No news of anyone much except that Malise Graham

30 the ] ythe TS 38 Les Greig] Les Gregg TS 50 Private X's ] Private P's TS 50 almost] alomost TS $5317^{\text {th }}$ ] 17 th TS 56 beer] bee r TS

38 Les Greig ] Leslie Alexander 'Les' Greig (1898-1984) A banker from Wellington working in Base Pay; his father came from Invercargill, perhaps explaining how Davin knew him.

55 falling out] Dropping back from the main march, unable to keep up the pace.

58 Thorpe Harrison ] Woodthorpe Jude

'Thorpe' Harrison (1916-1997) At Balliol with

Davin. He trained as an economist, fought in
North Africa, and ended the war in Greece. He became a teacher at Hasmonean school. 59 O.C.T.U.] Officer Cadet Training Unit. 59 Malise Graham ] Malise Lynedoch de la Trémouille Moray Graham (1916-1998) Balliol contemporary of Davin's. He enlisted in the Argyll and Sutherland Highlanders; from 1945-1946 he represented the British Army on the staff of the Soviet commander in Dresden. He died in America. 
is a C.O. and as such getting hell driving an ambulance in London.

Parcel received from Winnie. She is a good wife for a man to have.

Political scene developing daily. Rumours of Russians in Rumania. But nothing sufficiently settled for one to be able to assess facts.

Played Rugby the other day - badly, out of training.

Went to a cocktail party the other evening. The usual tedious affair: either you chase about desperately to catch a woman and become persona grata to the hostess or you stand in a corner, a centre of sullen stability, drink rapidly, discourse cynically to other malcontents and leave early.

There goes the siren again with its suprahuman wail and the characteristic dying and waking hum of a German bomber.

I wonder what are the things I might write and don't in this diary which might conceivably interest me if I ever reread thi it.

Have borrowed a copy of Tennyson to reread and revalue him. I still like Ulysses. Am reading Mr Norris Changes Trains and Zernatto's Die Wahrheit Uber Oesterreich.

Feel too dull tonight to go on with this.

\section{Sat $19^{\text {th }}$}

Rex King's motto: united we stand; divided you fall.

Haunted by mysteries, life, time, and death

Which does not solve but makes an end of both

I have pondered these since first my mind took breath

And raked dead ashes for glow, being loth

To hold that suns Catullus saw have left

No light beyond his bitter line, a dream

Which men have dreamt should live ghostlike bereft

Of flesh, mote merely where mad fancies beam.

Dust-doomed the vanished hands stretch out.

Old longings haunt our hearts. Our loves

10 suprahuman] superhuman TS $179^{\text {th }}$ 19th TS 20 both] breath[both] TS 23 saw] s w TS

1 C.O. and as such getting hell ] Here, conscientious objector rather than commanding officer. Malise Graham was in the Army by November. ${ }^{116}$

3 Rumours of Russians in Rumania. ]

Inaccurate rumours; Romania had lost territory to Russia a few months prior in a negotiated settlement, however.

15 Mr Norris Changes Trains] Christopher Isherwood, 1935.

15 Zernatto's Die Wahrheit Uber Oesterreich ]

The Truth about Austria; Davin was clearly influenced by the argument that Austria was an unwilling victim of aggression; see the discussion of Austrians on May 5th, 1941 (p.99). 17 Sat $19^{\text {th }}$ ] A caricature of a face is drawn alongside this heading in the holograph. 23 that suns Catullus saw] A reference to Catullus 5: 'soles occidere et redire possunt I nobis, cum semel occidit brevis lux / nox est perpetua una dormienda.' (Suns may set and rise again. / For us, when the short light has once set, / remains to be slept the sleep of one unbroken night.) 
Are cankered by the envious dead we have not known

And their ironic smile lingers

Lingers On our lovingness. Dead fingers

Stray with ours on living flesh,

Outside in the interminable night

Wolves exiled from the light

Their jealousies prowl still

About the brief campfires of our love.

Living a ghoulish life

[31] Within the echoes of our laughter.

No brief[short] eternity of bliss time does not mock

With his foreclosure, and our Siberian road

To the last waste we share with unseen ghosts,

Companions whose delight

Dwells in the defeat that lurks

Within our little now and mars

The apple of our happiness.

17 Oct. 1940.

\section{$20^{\text {th }}$ Oct. Sunday.}

Drinking at Royal Star with Jones - nice man but like so many nice men dull. Met Norman Noakes. Has been in field five weeks, hence failure to visit Winnie. Church parade this morning. What does in principio erat et verbum erat deus et verbum erad apud deum' mean? And who produced the current translation of these things?

Am thinking of giving a lecture on escape.

Spent quarter of an hour this morning watching the autumn in the valley. A 25 fascinating season: the unity of colour passes to variety and thence to decay. These golds are decadent. A lovely morning. 'Reform the body of our loneliness' was a 7 prowl] [prowl] TS 11 brief[short] ] short TS $1920^{\text {th }}$ Oct.] 20 Oct TS 23 these] thes e TS 26 the ] te TS

1 the envious dead] The phrase appears in John Dos Passos' 'Winter in Castile'. 20 Jones ] Noel Jones (1914-1987) The battalion's signals officer, a real-estate agent from Nelson. He lost a leg in November 1941 and was invalided home.

22-23 What does 'in principio erat et verbum erat deus et verbum erad apud deum' mean? And who produced the current translation of these things?] The answer to the first question is not a matter of translation, but of theological meaning; the verse is the most well known of all, John 1:1, then said at the conclusion of every Mass: 'In the beginning was the Word, and the Word was with God, and the Word was God.' The second is more difficult to understand; Davin must be referring either to the translation from Greek to Latin, in which case he should have known that the 'current translation' was the Vulgate, or to a translation into English which he does not give.

27-1 Reform the body of our loneliness... this morning ] The phrase has not been traced; it does not come from the missal, and may either be from a sermon or a hymn. 
beautiful phrase from Mass this morning. I am missing Winnie. I was lonely for her as I watched the mist and the gold on the hillside. My head is full of phrases and half-lines for poems but I have no crystallised thought to clothe with them.

\section{Oct Wed:}

Monday night a strange occurrence. Went to the White Horse and had seven pints with Dick Connolly and Ted Richards. Came home sober, went to bed and read for a while before going to sleep. Awoke very early in great pain. Examining the cause of it found that large pieces of skin had been torn off my shoulders, spine, hips and heels. Also my thumb was sprained and I had obviously had a violent blow on the side of the head. In great perplexity rehearsed all the events of the night but though I had no difficulty in recalling them found no explanation. Could enly recall having been very excited at a faint chance of getting to Mytchett on the following day. (It didn't come off.) When Rex King woke asked him if he knew anything. Yes, he knew a lot. He had been half-awakened by a scrabbling noise at the table. Then he had heard a fumble at the door and seen me naked go out in a wavy way. Still half asleep he had thought: that man will fall. A loud crash and a queer cry awoke him. He rushed out and switching on the light saw me lying in a heap at the bottom of the stairs. He called to me to come up. I refused. He carried me up. I got into his bed and refused to get out. He carried me out to my bed. On getting in I apologised with surprise for having got into his bed. I got up and went to the lavatory. He followed. I said I wanted to be sick. Came out after a while and said I couldn't and went back to bed. Asked him to put out the light. He did so and locked the door. I said 'I asked you to lock the light, not put out the door.' Went to sleep.

I had been talking a lot in my sleep earlier and must have walked under the compulsion of some strange dream. After the fall I must have been either concussed or still asleep. Certainly not drunk since I was sober on coming home and have often drunk more without anything of the kind occurring. On Tuesday played Rugby somewhat painfully. Arrived back to find Captain Manson in the process of instalment. The 3123 Oct Wed: ] 25 Oct Wed. TS 40 off.) ] off. ) TS 40 woke] awoke TS 42 fumble] fum[b]le TS 47 went] went down TS 47 lavatory] lavaory TS 47 followed. I] followed I TS 48 couldn't] could't TS 56 find] fin TS

32 White Horse ] The White Horse Inn, Bearsted, Kent. Major Fyfe remembered it: 'There we gathered in the evenings with our friends from the nearby 'drome; there, while our host, kindly "Uncle Ben" beamed over our games of darts and shove ha'penny, his charming wife sang with us at the piano.'117 56 Manson ] Ian Oliver Manson (1905-1992) The commander of D Company, also from Invercargill.

56-1 The Brigadier] Alexander Smith 'Acky'
Falconer (1892-1966) The initial commander of the battalion, a brigade major in the First World War. He commanded the temporary 7 Brigade in England before returning to the battalion in Egypt. He very briefly commanded brigades again on Crete, then was in charge of, successively, Maadi camp and a home service divison before becoming the overseas commissioner of the NZ Patriotic Fund Board until the end of the war. 
Brigadier blew in to ask Mark to go on a camouflage course. A graceful cloaking of Mark's exit, I suspect. Surprisingly felt sorry to lose him: he was testy, suspicious, sharp, small and narrow. But he was not a bad sort and we were beginning to get him under control. We had got him to some extent in our power. And now we must start all over again on the patient task of mastering our Coy C.O. However the new one, an Invercargill Town Clerk, dour, humourless and without warmth, thorough and probably exacting, is due to go on a course next week and we shall be ourselves again.

Before leaving Mark did me the good turn of explai[ni]ng he had given me leave for the coming weekend. Manson responded w little enthusiasm but I think I shall get it. I'd better because I'll go crazy if I stay here much longer and it's a long time since I heard from Winnie. A weekend of quiet love with her and little Anna wd restore me to comparative sanity.

How do I know I'm not going mad? So much goes on in me that I knew very little about. 'Reform the body of my loneliness.' Winnie is the most portmanteau person I have ever known - wife, lover, friend, woman, man, mother, adviser, trustee, protector, co-knower of me, and co-forgiver, having courage, charity, love and honesty, being generous, understanding and kind, yet proud and free-spirited. A wife.

Last night in Maidstone met WW, just returned from a week's leave in Oxford and Cambridge probably spent mostly $\mathrm{w}$ his love. Contemplates divorce and marriage. A terrible judge of women, I fear. Like most of these surface-clever men. The woman is a man-eater even if she never eats more than two.

Today behaved acc to syllabus in the morning and managed to get along. This afternoon a court of inquiry into a collision involving the Colonel's car. Car accidents do not interest me but by doodling I was able to rid my half-conscious of some of its nightmares. I like courts of inquiry although they are boring. It is interesting to observe how difficult most people find it to give a direct answer to a simple question. Whether men's minds are less or more tortuous than their spoken answers show them I don't know, probably more. An educated man can give a more coherent account and though I suppose it should not this surprises me. Apparently even plain common sense is an artificial product. Education however imperfect does something to build logic's Roman Road, avoiding associative irrelevance. It seems that it needs far more

[33] discipline than / we know to proceed from one idea to the next by the direct coercive route of logic and dismiss the sideroads.

61 C.O.] CO. TS 62 dour, humourless ] humourless TS $65 \mathrm{w}$ ] with TS 72 co-forgiver] cOforgiver TS 72 charity] chastity TS 75 whis] with hos TS 76 men] me TS 80 of] od TS 88 from ] vfrom TS 89 sideroads ] side-roads TS 1 Friday $25^{\text {th }}$ :] Friday 25th (Oct) TS

Davin's verdict, given in his diary entry for the $26^{\text {th }}$ of September 1941, was 'Pity he's a fool in politics because he's not a bad specimen of a man.'

62 Invercargill Town Clerk] The main administrative officer of the town council. 87 logic's Roman Road ] That is, straight and direct as Roman roads were, rather than winding, and without diversion. See also the reference to royal roads, p.3. 
Friday $25^{\text {th }}$ :

Somewhat dreary day yesterday with no excitements. Went to bed at nine o'clock with the idea of getting a long sleep and perhaps curing the cold and headache I have had since my fall. Awakened at 3 o'clock this morning by signallers: 'All troops to 5 stand by and be ready to leave as soon as possible.' We stood by. At 7.30. 'Stand down. Carry on as usual.' We sent the men back to bed till ten and I dozed and read. Whether a practice or a genuine alarm I don't know but most infuriating. Still another peak day has gone by without invasion. But my weekend so patiently planned for now looks like slipping me: I have one last desperate card — desperate because open — to apply outright to the Colonel. The letter is written and will go over in the morning. I have little hope of leave and even if I get it a difficult task in getting to Mytchett but somehow it must be tried. This morning I dreamt that I came into this room and there was Winnie and Hart Massey and many more old friends. Never have I been so elated. But Rex King clumped in and there I was with no-one.

This afternoon a Coy scheme, wet and somewhat miserable. I am getting stale besides which my cold is worse and the coughs make the back of my head feel about to jump off.

Read Edgar Wallace's 'More Educated Evans'. Verve and in places fine genre stuff, but like Damon Runyon's stuff, ceases to interest because range of technique too small. You soon know what to expect and as that is nothing much without its novelty the book becomes tiresome. Yet lively.

It is towards nine o' clock of a bitter night, with a wind cold and high. I am roosting up in the room in a dressing-gown, half hoping Tom Morten will come in in which case I shall go out and walk two miles for a drink and a few less familiar faces, half-hoping he won't since it would be better for my cold and pocket if he doesn't.

There is a good deal on in the air as there has been most of the day.

$\overline{2}$ o'clock] O'clock TS 5 and] abd TS 5 by. At] by.At TS $\quad 5$ Stand] stand TS 6 sent] s sent TS 6 dozed] dpzed TS $\mathbf{1 6}$ my head feel] my feel TS 18 Verve and in] Verve in TS 19 too] tooo TS 22 o'clock] on'clock TS 23 Morten] Morton TS $\left.127^{\text {th }}\right] 27^{\text {th }}$ TS

6-7 Whether a practice or a genuine alarm I don't know but most infuriating] It was neither; 'the whole operation was a snap trial. The Maoris took being turned out of bed in the middle of the night much more philosophically than some other units, whose comments were couched in language suitable to the occasion but quite unprintable. ${ }^{.118}$

13 Hart Massey] Hart Parkin Vincent Massey (1918-1996) A friend from Balliol; at this time, a fighter pilot in the Canadian Air Force. He was the son of Charles Vincent Massey, the first native-born governor-general of Canada. $\mathrm{He}$ studied architecture after the war. 18 Edgar Wallace ] Edgar Wallace (1875-1932)
Prolific English writer, the original author of the screenplay for King Kong. More Educated Evans is the second of a series of three comic novels about Educated Evans, once 'World's Champion Prophet and Turf Adviser' and master of misguided historical allusions. After he wins a fortune touting bets and loses it trying to train horses, he returns to Camden Town. The novel traces his eventual return to success by way of various maladroit schemes. 19 Damon Runyon] Damon Runyon (1880-1946) American short-story writer; Davin is comparing the social setting of More Educated Evans to Runyon's celebration of urban New York. 
Sunday $27^{\text {th }}$ Oct.

My 'pressing private and domestic affairs' worked. Against all hope I got leave yesterday morning. Shot into Maidstone, took bus to London. Ate at Colombo's. A bomb had fallen an hour earlier in Rupert St. and my usual route to Soho was cut off thus. London surprisingly little changed except for an occasional bombed house, showing like a tooth gap. Trained from Waterloo to Ash Vale. Walked because too impatient to wait for the bus which followed a few minutes after. Winnie was walking home from shopping and we descried each other from afar. She recognised me by my carrying books, having a NZ hat, having a long coat, and my characteristic walk - a

[34] unique | combination apparently. I knew her by her raincoat, the hat we bought at Halls, and something about her legs and gait.

The baby was fed and we fed. Then to bed. Then up again to the Queen's much less thronged than formerly. A tedious Canadian talked to us, drunk and liable to become unpleasant. Otherwise nice evening. Home again I fell asleep before the fire and Winnie says I complained of a guardsman lying across my chest. Rose this morning to fine breakfast of toast, sausages, bacon, tea, and Sunday Times. Winnie's life is now entirely governed by the ritual of Anna. The little tyrant leaves her little leisure and no respite from concern. But she likes this fond dictation and it fills her life and the gap left by my absence. Charming morning before the fire with the hours escaping only too quickly. Good lunch and then after more sitting and the feasting of Anna I must catch the 3.19 for London. So here am I sitting in the train, now stopped at Woking and doing my best to write in somewhat adverse conditions - still nothing to read and absence of something to criticise compels creation.

3 Colombo's ] Colo mbo's TS 9 having a NZ hat, having a long coat, ] having a NZ hat, TS 10 raincoat, ] rainco at, TS 21 for] from[for] TS

9 having a NZ hat] New Zealand soldiers wore a distinctive 'lemon-squeezer' hat occasionally. ${ }^{119}$ In 23 Battalion, 'the Kiwi peaked hat was worn on leave ... mainly to give the people a lift. It demonstrated that a convoy had arrived from the Antipodes at a time when the Hun was claiming to sink practically all shipping that left port. ${ }^{, 120}$ 11 Halls ] See note on p. 26. 12 Queen's ] A military tavern near Aldershot; Bassett describes it as 'a vast assortment of bars, graded from the select officers only, then officers and cadets only, cadets and W.O's only, and other ranks. ${ }^{121}$ Earlier in the diaries, Davin saw it as 'where discourtesy is paramount and the service bad, place supported by its snobbery. But the majors, probably the gourmets of the army, do not dine there. Notice that Cox is a determined habitue' (Sept 3, 1940) (Cox: 'our favourite off-duty gathering place. ${ }^{122}$ )

15 a guardsman lying across my chest ] A member of the elite English guards regiments: before the war, they were selected for their height and intimidating size. When the Coldstream Guards relieved 22 NZ Battalion at Cassino, 'the leader towering about the 6 ' 7 " mark, the other three in the vicinity of $6^{\prime} 5^{\prime \prime}$, Lt. Monaghan started to show them the layout and advised me [Private Lee] to be alert as they were so big they must hit something. A few seconds later there was a huge crash and I went to investigate and found the lieutenant picking himself up from a heap of tins. The Guards' changeover was perfect. ${ }^{123}$ 
So, it was a lovely weekend, my cold is much better and I am saved from fedupness. Winnie and Anna are thriving and perhaps I shall soon be in Camberley. Should leave London at 7.45 .

Winnie told me the story of Mrs Greenland's grandfather. He would never wear 5 pyjama trousers. In old age the doctor told grandmother that he might live a long time or he might die at any time. She insisted he should wear pyjama trousers. He refused. Finally she broke down and explained he might die at any time and what would people think of her if he an old man of 78 were found wearing no pyjama trousers.

\section{Monday $28^{\text {th }}$ Oct.}

Reached London, ate at Bertorelli's. Much changed - thronged at 5.45, beer available before 7, upstairs closed, shuts at 6.30 . London seemed normal by day, but after dark few people about except loitering whores and hurrying men.

Leicester Sq. badly knocked about. Panton Club's windows blown out, a shell only. Shrapnel in the doors of the Cafe Royal. Took 7.45 bus and reached home without incident.

This morning rather a loaf. K. told me of a girl he picked up in Leeds. Beautiful, young, claiming to be married to an unemployed temporary invalid and fed up. Proposed to go into the game! King interested suggests further meeting. Meets her, buys her a coat, lends her $£_{3}$, proposes to meet her again and lend her $£ 10$, finding her a flat. In fact is about to set up as a maquereau, though he doesn't quite realise it, such is his mentality. It is for him an 'investment', a title sufficient to destroy its dubiousness. But she does not reappear. In fact says he it was an ingenious way of extracting $\mathfrak{z}_{3}$ for a night - and he who had never paid more than 10/- .

Later the same night being broke he told the stationmaster his $\mid$ address and was allowed to travel. He sat next to an old invalid who had a bottle of whiskey. As he had a hangover this was very tempting. With enough whiskey the old boy expanded and shared. They both had to change at the same station and King helped the old fellow to the waiting-room and a place by the fire. The police came round viewing all tickets

$928^{\text {th }}$ ] 28 th TS 13 Sq.] Square TS 13 Panton Club's] Panton Club TS 18 game!] game. TS $19 £ 10$ ] 110 TS 21 'investment'] investment TS 24 told] tolld TS 25 travel] travvel TS 28 viewing ] viweing TS

4 Mrs Greenland] Not identified. 10 Bertorelli's ] One of several linked Italian restaurants of that name; Davin favoured the original branch in Charlotte Street, Fitzrovia. He went there 'for a solitary meal' after hearing of Anna's birth. ${ }^{124}$ 13 Panton Club's ] Not the Panton Arts Club, previously run by Edith M. Fry. This was defunct by the mid-1930s. Rather, a club in Panton Street, off Leicester Square; an anonymous article in Men Lonely, the troopship magazine co-edited by Davin, describes it as 'a theatre club, much haunted by more or less broke music hall artists and Bohemian rouseabouts. And it has for one reason or another known many New Zealanders.' This article was almost certainly written by Davin, since it goes on to list the first names of his friends and their fates in response to a barmaid's question.

14 Cafe Royal ] A popular café of the Belle Époque, in Regent Street. 20 maquereau ] A pimp. 
to make sure there were no vagrants. Rex told his story and was believed. But the old man had no ticket either. In addition he blurted out 'And this man stole my whiskey'. Things looked very black because now the object of fresh suspicion Rex had no means of identification. But a chance football acquaintance's arrival saved him.

Italy attacked Greece this morning and Greece has declared war. What now?

W.W. blew in this evening with motorbike, given him as entertainments officer. His book has been accepted, so he is in high fettle. He called in yesterday as well. But what he is after I can't yet discover. Perhaps just to tell me. But he usually has something up his sleeve. The presence of others must have made him keep whatever he had to himself.

\section{Saturday $3^{\text {rd }}$ Nov.}

Am officer on duty with everyone away and tomorrow will be bn orderly officer. Not a v. interesting week behind us. Was officer under instruction at a C.M. one day but cases were uninteresting and did not learn. Plain cases of AWL with pleas of guilty. Yesterday Bn Stunt: usual rather confused business but managed to force me out of a depression. Tully giving much trouble put on charge: last night pay night platoon got drunk: Tully and Fowler are AWL: Cpl Harrison spent the night with a woman who lives across the road and did not appear at stand-to: Kennedy refused to get up for stand-to. All on charges.

Met private called Bill Stafford who knew me at school: remember the name well 20 but can't remember anything else.

Brian Bassett is trying to reconnoitre for me the education situation with possible results. Am now thoroughly tired of pln co's job and eager for change.

$113^{\text {rd }}$ Nov] 3 rd No TS 17 Harrison] Harrision TS

6-7 His book] Probably his The Last Journey, published 1941.

13 officer under instruction ] Officer in attendance at a court-martial for instruction in the procedures and functions of the court (not taking part).

13 C.M. ] court martial.

16 Tully ] Roy Tulley (1917-1985) A West

Coast private in Davin's platoon who was an 'acting fireman.'

17 Fowler ] Ashley Edward Fowler (1912-1943) A private from Nelson in Davin's platoon. He was killed in Tunisia.

17 Cpl Harrison ] James Harrison (1909-1976)

A corporal in Davin's platoon, a waterside worker from Greymouth.

18 Kennedy] Michael John Kennedy (1911-1985) Private in Davin's platoon, a labourer from Rapahoe. He was wounded on
Crete.

20 Bill Stafford] William Archibald 'Bill' Stafford (1913-1987) A private in 23 Battalion. He was a storeman in Dunedin, but had been educated with Davin in Invercargill. He started with the Marist Brothers in 1919. Davin was only enrolled in 1921, perhaps explaining the vagueness of his memory. 22 Brian Bassett ] Brian Irvin Bassett (1911-1942) The intelligence officer of 23 Battalion, in civilian life a Christchurch lawyer. Davin replaced him when he was promoted to be Kippenberger's Brigade Major. He died when his vehicle was strafed by enemy aircraft in the desert.

22 the education situation ] A place in the Education Corps. Before the war began, Davin had planned to take up a Worker's Educational Association lectureship. ${ }^{125}$ 
Spent last evening w Gordon Cunningham whom I like well and others at White Horse Bearsted.

Rex has gone off for weekend after his London prey.

We leave for Camberley all being well on Monday. How glad I shall be to be out of 5 this unprofitable place. May get to see Winnie Monday night.

\section{Sunday Nov 3rd [(?.th)]}

Paid Hall's £5. Wrote home. Read letter of Geoff F's. John G of Johannesburg administered euthanasia to his father: benevolent parricide.

\section{Wednesday Nov $6^{\text {th }} \quad$ Camberley}

Arrived here Monday 4th. As soon as men were installed got leave and lift to Mytchett. Found Winnie and baby in excellent form and not expecting me till following day. Spent delightful evening. Walked home five miles or so and $\mid$ then to bed. Yesterday spent straightening things up w route march in the afternoon. Messing w B Coy, MO and DO. Manson left on 7 weeks' course last night.

Tom Morten now Coy CO, Dick Connolly 2 i.c. Sandy Thomas back w Coy. Fairly able, extremely self-confident - and self-confidence is a military virtue, alas - young,

$1 \mathrm{w}]$ with TS 2 Bearsted] Bearstead TS 4 be to] be. to TS 6 Nov 3 rd [(? 4 th)] ] Nov $3^{\text {rd }}$ MS 7 John G] John G[(luckmann)] TS 9 Nov $^{\text {th }} \quad$ Camberley] Nov 6th Camberley TS 15 Morten ]

Morton TS

7 Paid Hall's E5 ] Probably Hall Brothers, a well known Oxford tailors. Rather a large bill, especially since he later pays $£ 2$ more (p. 42) but Geoffrey Cox bought his army overcoat there, ${ }^{126}$ and Davin may have done the same. A new battledress for Dick Orbell from an unknown tailors cost $£$ 7.10.0. ${ }^{127}$

7 John G] Jonathon 'Jon' Gluckman (1914-1993) A South African pathologist from a prosperous family involved in the development of citrus farming land; Davin and Flavell had known his sister Judith, who was an artist in Paris. ${ }^{128}$

No other evidence of Flavell's story has been found, and the letter does not survive.

However, Nathaniel Gluckman, presumably his father, did die in South Africa in 1940.

9 Camberley] A town in Surrey, south-west of London. As the threat of invasion diminished, there was no reason to remain in Mytchett. 23 Battalion therefore moved to Camberley, where evacuated civilian housing was available. ${ }^{129}$

13 MO ] Medical Officer.

14 DO] The meaning of this abbreviation is unclear, but Davin's use of it in both the MS and TS suggests it is not an error. The DMO was the director of medical operations, but this was not a battalion-level position.

15 Sandy Thomas ] Walter Babington 'Sandy' Thomas (1918-) One of C Company's three subalterns, along with Rex King and Davin. He was a young bank clerk before the war began, but went on to a very sucessful career in the British Army after the war, ending as Commander Far East Land Forces. He was wounded and taken prisoner on Crete, then escaped in Nov 1941 and returned to the Div, where he eventually commanded 23 Battalion. $\mathrm{He}$ and his story are clearly recognisable as 'Rusty' in For the Rest of Our Lives. His narrative of his escape from Greece, Dare to be Free, was a bestseller in the nineteen-fifties.

'Like an amiable cyclone, an immense young New Zealander ... a lion-hearted young man. ${ }^{130}$

15 back w Coy. ] He had been hospitalised with dysentery, then was left in charge of the remnants of the Mytchett camp as they were 
cunning, pleasant but irritating. Luckily with Manson gone and Tom unsusceptible to flattery and almost free from vanity it should not be hard to prove to match him. Especially w King and Connolly as allies.

Bn dinner on Friday night - may go, although at the moment severely poor. Might be good diplomatic move.

Last night went $\mathrm{w}$ Ted Thompson to Farnborough by bicycle. His girl was inaccessible so brought him to Mytchett. Three of us went to Miners' Arms. I came back $\mathrm{w}$ Winnie and slept till six getting back here at seven after an annoying ride in heavy rain and road-doubting. Am becoming jealous of Anna and annoyed w Winnie for her absolute absorption - sillily because it's natural and being fond of Anna myself I'm glad of it. But there it is. I have a formidable rival, and not merely a rival but a re-orienter of Winnie's ideas and attitudes.

Today again interior economy and not much to do. Read Wilde's Ideal Husband. The succession of epigrams becomes a little monotonous and out of consequent irritation one is maliciously pleased, though not freed the let-down of the failure, when an epigram misses. Yet there's some good sound sense in the play of quite a good strength.

Went into Camberley to buy things this morning. Braved my great hatred of Woolworths to go in. But the atmosphere of bawling babies, bargains, cheapness and ruthless economic woman made me glad when I found there was no Blanco and I was able to flee. Hence to another shop where impatience at queues combined $w$ former discomfort to drive me out again. Advertised in local paper for digs for Winnie.

Tonight probably have to stay home on duty: if not, will go to Mytchett again, I suppose.

\section{Sunday 16th Nov.}

All ready to go out but it's raining heavily so I shall wait a while. Going to Mytchett. We have found digs for Winnie in Lower Gordon Street and she will be shifting next Thursday. I go on leave on Monday. Shall probably spend Monday and Tuesday nights in Rochford w Geoff and then back to Mytchett to help with the shift. Prospect of even this brief leave is wonderful. To be free for a while, to be able to move without stating a time, without marching there, without being responsible for anyone. Not to need to care for a whole week.

[37] Till last night had had only two pints for a week. Seriously | worried about money again, the same old debts, only Balliol and the bank are getting restless now.

1 unsusceptible ] unsusceptble TS

dismantled. ${ }^{131}$ The increased focus on him comes since he and Davin now shared a room. ${ }^{132}$

Hospital Service, the centralised precursor to the NHS formed to treat air-raid casualties. (Rochford was a target because of RAF

19 Blanco ] A compound used to clean and Rochford, the future site of Southend Airport.) colour military uniforms.

28 in Rochford w Geoff] Flavell was briefly He would soon move to Brompton Hospital, and then to become a surgeon for the RAF in living there while working at Southend the Middle East. 
Last night went to the Duke of York w Dick Connolly. Nothing of gt note. Pub kept going late because landlady owing to air raids was afraid to go to bed.

Just finished De Quincey's Confessions. 'Of this, at least, I feel assured, that there is no such thing as ultimate forgetting: traces once impressed upon the memory are indestructible; a thousand accidents may and will interpose a veil between our present consciousness and the secret inscriptions in the mind. Accidents of the same sort will also rend away this veil. But alike whether veiled or unveiled, the inscription remains for ever; just as the stars seem to withdraw before the common light of day, whereas, in fact, we all know that it is the light of day which is drawn over them as a veil, and that they are waiting to be revealed, whenever the obscuring daylight itself shall have withdrawn.'

Memorable meanness of the C.O. Battalion dinner: port served to all the guests: King's health drunk: waiter comes round each guest for $1 / 3$. What for? For the port.

$18^{\text {th }}$ Nov. Monday.

Sitting in bar of Liverpool St. Station w light ale in front of me, forty minutes to wait for Rochford train.

Got leave yesterday from Tommy Morten to begin my week's leave then. Cycled to Mytchett and spent the afternoon reading and talking w Winnie and Anna. Anna is beginning to show signs of great attachment to me - unless her smiles are dictated merely by her sense of the grotesque. Yesterday she made her first attempt at crawling - a failure because it didn't occur to her to use her arms for locomotion as well as support.

Much annoyed w the CO because he refuses to allow Cpl Ryan to apply for a transfer to Pay when I thought I had it fixed. Selfish.

Last night Winnie and I went to Angler's Rest for an hour, where we developed theory that the conscience and sin being Xian creations inhibitions in their most developed form are Xian creations and Xianity is $\therefore$ responsible for fias Freud.

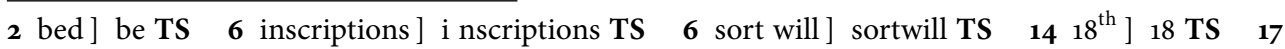
Morten] Morton TS $18 \mathrm{w}$ ] to TS 21 didn't] didndt TS 23 Ryan to apply] Ryan apply TS 26-27 and sin being Xian creations inhibitions in their most developed form are Xian creations and Xianity is $\therefore$ responsible for Freud.] andsin Freud. TS

1 Duke of York] A pub in Camberley. 3-4 Of this, at least, I feel assured, that there is no such thing as ultimate forgetting ] Probably copied with regard to the 'recapture of memory story', discussed on 8 September: p. 1. 23 Ryan ] Augustine John Ryan (1907-1961) Corporal in Davin's platoon, a school-teacher at Kongahu. 
Have had a letter from Bob Cotterall earnest and uneasy but pathetic because affectionate exhorting me to attend the sacrament. Reminds me of Chamberlain (now at last dead since there is no more mischief he could wreak) trying to convert Hitler.

This morning took $11.19 \mathrm{fr}$ Ash Vale to Woking. Changed to a fast train there, forgot my case and $\therefore$ had to wait at Waterloo for slow train to arrive. Festina lente.

Bought beautifully bound 3 vol Teubner edition of Ovid on Saturday in delightful bookshop: the only tolerable spot in Aldershot. 4/6. Couldn't resist it. There is a [38] beautiful Charles d'Orleans there. I should like to / buy Winnie for a Xmas present.

Winnie has lent $m e £ 25$. Am paying $£ 15$ to my bank, $£ 5$ to Balliol, and returning $\mathfrak{f}_{5}$ to her.

It is quite exciting to be in London again though I never know quite why. 'Blindly I blundered through the maze of stone, the mighty wormcast of men, evading narrowly fate's capricious heel.'

\section{Monday. 25 Nov}

Reached Rochford that afternoon. Geoff was in London receiving his Fellowship. Returned in the evening and we went to the pub and had a few pints. Back to the house and played chess till 3 a.m. drinking a bottle of whiskey. Geoff had many stories: the Glasgow Highlander who took prisoner a German airman and two Grenadier guardsmen who had swum across the river to catch the German and were caught

$5 \therefore$ ] therefore TS 5.$]$.. TS 19 catch ] cath TS

1 Bob Cotterall ] Robert Charlton 'Ponsonby' Cotterall (1913-2007) A friend of Davin's at Sacred Heart; M.K. Joseph remembered him as devoutly Catholic, 'a good heart and an acid wit. ${ }^{3133} \mathrm{He}$ became an intelligence corporal in the Div Cav in Italy; the high point of his service was perhaps his liberation of Montegufoni, the Italian house of the Sitwell family.

2 to attend the sacrament.] Either go to Confession or Holy Communion. The first would probably, in Cotterall's view, be a prerequisite for the latter.

2 Chamberlain ] Arthur Neville Chamberlain (1869-1940) The Prime Minister in the lead-up to war, and in its early days. He died on 9 November 1940.

5 Festina lente ] A Latin adage: make haste slowly.

6 Teubner edition ] One of the Bibliotheca Teubneria, German-produced critical editions of classical literature comparable to the Oxford Classical Texts series.
8 Charles d'Orleans] Charles d'Orleans (1394-1465) Poet and Duke of Orleans; taken prisoner at Agincourt, his place in the French succession was too important to allow his release for twenty-four years. In this duration he wrote poems in both English and French; he is a minor character in Henry $V$. 'A beautiful Charles d'Orleans' is an edition of his poetry. 11-13 'Blindly I blundered through the maze of stone, the mighty wormcast of men, evading narrowly fate's capricious heel.' ] No source for this quotation has been identified. Its delight in alliteration and adjectives is reminiscent of Davin's early work; it may be a phrase for insertion in a planned story. c.f the description of Joyce Cary's drawing room in Closing Times: 'A room, then, at once the background and cast - wormcast, he would have said - of a writer. ${ }^{134}$

15 his Fellowship ] Flavell's Fellowship of the Royal College of Surgeons; the equivalent of a FRACS in New Zealand. 
without their identity cards: an alarming night at Geoffrey Loxton's house: the British who were looking for a German parachutist and saw his legs hanging in a tree: Says the Sergeant: keep a close look-out for a limping German.

Next morning we breakfasted, played chess, went into Southend for lunch, drank and talked all day, went to the hospital and drank there till midnight. In the morning both of us exhausted and depressed: we seem to have the effect on each other of stimulation to extraordinary lengths of mad, nonsensical crazy gabble so that in the morning we are more exhausted by the evening's inspired nonsense than by alcohol.

Back to London on the Wednesday, lunched Chez Durand and home to Mytchett completely exhausted.

Thursday bicycled to Camberley, borrowed truck, shifted Winnie, Anna and the goods and chattels. New digs very crazy place. Only occupants distressed gentlewoman of 70 and her bed-ridden mother of 9o. Dirt everywhere though Miss Gillespie evidently regards herself as a good housekeeper. First couple of days spent in attempts at cleaning place up.

Saturday afternoon began to write a story: combination of Armenian in Paris and memory recapture. Wrote again yesterday but not very pleased. Seem to have lost flexibility and in frantic haste to get it written while mood is on can't risk the leisure to let the imagination expand. Went back to battalion last night and slept there but found this morning that leave doesn't expire till tonight. So home again, hope to write again this afternoon. Have been reading Balzac's Peau de Chagrin. Apart from fantastic framework writing excellent though Byron's Childe Harold - Don Juan seems to have been as ubiquitous in the 19th century as the neutral, passive, observant Paul Pennyfeather of our time.

Letter from Arthur Pyper: married and epileptic: thus free from the war. Roger Lloyd staying with him in Belfast.

Have paid $£ 5$ to College, present bank state overdraught of $11 / 2 "$.

$\mathbf{1}$ the] thr TS 2 parachutist] paracutist TS 3 look-out] look-Out TS $\mathbf{8}$ inspired nonsense] ispired nonsence TS 8 alcohol] the alcohol TS 11 Camberley, borrowed truck, shifted] Camberley, shifted TS 13 though] yhough TS 13 Gillespie] Gilleppie TS $\mathbf{1 6}$ combination] cobination TS 17 Seem ] See,m TS 17 have] hve TS $\mathbf{1 8}$ mood] the mood TS 20 found this morning] found TS 22 Harold - ] Harold- TS 24 time.] time. Wrote to Bill Sitwell 25th Nov. TS 27 state ] state TS 27 overdraught] overdraft TS

1 Geoffrey Loxton] Geoffrey Ernest Loxton (1910-1974) An English physician, specialising in rheumatology and medical statistics. He trained at St. Barts with Geoffrey Flavell. 5 went to the hospital and drank there till midnight ] Until relatively recently it was traditional for junior medical staff to live in or very near to their hospital.

13 Miss Gillespie ] Not identified; evidently Winnie's landlady. She described her as a 'valiant English 65-year-old'. ${ }^{135}$ 19 expand. ] In the top margin of the new page of the holograph is 'Wrote to Bill Sitwell 25th Nov.'

23-24 Paul Pennyfeather] The suffering protagonist of Waugh's Decline and Fall. 25 Arthur Pyper ] Arthur Spring-Rice Pyper (1916-After 1992; before 1997) Another Balliol contemporary; he became a teacher after the war.

25-26 Roger Lloyd] Roger Kynaston Lloyd (1915-1977) A Balliol contemporary. He went into the navy, lost an arm in 1941, and became an advertising executive in later life. 27 College ] Balliol College; see anxiety about his debts to them, p. 27. 
This morning Craigavon reported dead. One stumbling-block out of the way. Greeks still following up the Italians.

[39]

Wed. $27^{\text {th }}$ Nov.

Yesterday inoculated w Tet. Went to dull football in afternoon. On duty at night and Winnie came to visit me. She was very tired and I am beginning to think the work of looking after the baby and cooking etc may be too much for her - especially as she is showing signs of teething. I am beginning to get very fond of the kid.

This morning called to prosecute at a CM 9.30, waited till 11.30, then CM postponed till afternoon. Brian Bassett will do it now and I shall play football.

Rumour now rife that we shall be leaving soon. All the evidence points to departure in about a week. Didn't have the heart to tell Winnie last night but must tell her today. Am most reluctant to go, leaving them behind. Winnie will worry all the time. Wish there were some safe way of sending her back to N.Z. And all our friends are so scattered, she will be lonely. Perhaps Ireland?

All very alarming since on the one hand I feel unfit for the job of commanding men since no-one is ever really fit for such a huge responsibility and on the other feel the job beneath some of my capacities.

Must finish my new story before I leave, somehow or other.

\section{Monday $2^{\text {nd }}$ December.}

'Hitler is the man of the inner comparative'

Konrad Heiden.

\section{Consummatio Mundi.}

Yesterday wrote these:

\footnotetext{
$427^{\text {th }}$ ] 27 th TS $5 \mathrm{w}$ ] with TS 6 very] ve ry TS 7 she] the baby TS 9 morning] mornong TS $\left.202^{\text {nd }}\right]$ 2nd TS

1 Craigavon ] James Craig (1871-1940)

Viscount Craigavon. An Orangeman serving as

Prime Minister of Northern Ireland. He was

well known in New Zealand after touring the country in the winter of 1929-30 gathering information on farming methods to apply to Ulster. ${ }^{136}$

The stumbling-block is presumably

Craigavon's opposition to a united Ireland.

2 Greeks still following up the Italians.] This paragraph is not present in the typescript.

5 Yesterday inoculated w Tet ] Given a tetanus vaccine.

13-14 Wish there were some safe way of sending her back to N.Z.] The wives of several
}

\author{
5
}


Life with high finality will stalk

His exit from the stage; and from

The world's great theatre where we have watched

His posturing light will depart and time,

To brood above the empty seats where once

We toiled and joyed in mindforged loves and hates,

Now abdicated.

Sunday $1^{\text {st }}$ Dec. 1940

What the Ghost Said.

Hungering to the mirror I see no face

Comfort my query.

Under the moon no shadow keeps my pace,

Though I wander so weary.

Living, my dearest love loved my embrace,

Wept at my leaving.

Unseen I return deathcold to my place,

She gives over no grieving.

Hungering at the bed's head I knew by her face,

Eagerly reading,

Shadowless soon she'll follow my trace,

Ghostly, answer my pleading.

Sunday $1^{\text {st }}$ Dec. 1940.

Yesterday I wrote these two and a little more of my story but not much.

Friday went to Godalming for a CM as defending officer. Sat all day in the cold, waiting, and drinking beer. It was postponed. Took place Saturday morning and we rushed it through. I should have made a better job but for anti-climax, haste, and a bad miscalculation in the plea.

Thursday we did a Coy stunt and rather to my surprise we did it well.

3 theatre] thatre TS 6 above] above TS 7 mindforged] midforged TS $91^{\text {st }}$ ] 1 st TS 11 mirror] mirro r TS 14 wander] w nder TS 21 follow my] followmy TS $231^{\text {st }}$ ] 1 st TS 
Saturday afternoon Ted came down fr Basingstoke. We motored to Effingham and saw the nuns. Anna great social success. In the evening came home and talked to King.

Significant for NZ's cultural standards that 'he's an artist' is a description of quizzical contempt.

This morning a lecture on camouflage. We were marched there by Major Fyfe. The army lecture is a very tedious thing: it lacks all spontaneity and usually has only the most elementary facts for its matter. Thus the length at which the obvious is expounded drives you into a contemptuous doze and at the end you awake without having learnt even the few simple things you were meant to.

Still no news of our departure.

\section{Tuesday Dec 3rd.}

'the causal gap: the inability to attribute everyday experiences to political cause.' Heiden.

Last night went to tedious musical comedy film. Stayed at Gordon House till 6.45. This morning gave lecture on scouts, read German and read Konrad Heiden's Hitler. This afternoon company has gone off to route march and watch football. I stay at home reading German. But something of the impetus has gone. Tonight will go again to Winnie's and perhaps be able to write some more. This dreadful reluctance to write warring with the hunger to. The days pass and we may soon be gone.

\section{Sunday Dec $8^{\text {th }}$.}

Took to bed on Friday with cold and flu. Likewise yesterday. But today better. Am now just returned from church parade: the awful tedium of sermons, the false emphasis and false emotionalism of them, how embarrassing. Wrinkled words rouged

$\mathbf{1} \mathrm{fr}]$ from TS 11 Dec $3 \mathrm{rd}$.] Sept $3^{\text {rd }}$ MS 12 the causal gap:] the causal gap8 TS $\mathbf{1 2}$ cause.] cause, TS $\left.208^{\text {th }}\right] 8$ th TS

1 Ted] Bernard Edward Paul 'Teddy' McCullough (1909-2005) An Otago contemporary of Davin's who had moved to England at the same time. He was serving in the RAMC as a surgeon, and meanwhile providing support for Winnie and Anna in Davin's absence. She quotes a letter to her sister which shows both the weaknesses and the strengths of his character (ellipsis and square brackets hers): 'Ted McCullough has been an angel to us... he is in the R.A.M.C now and is hoping to be sent east soon. [He was.] He has specialized in Anaesthetics and often used to work with Sir Harold Gillies at his last hospital. One night with him I met an ex-patient of his whose face had had been burnt-out by an incendiary bomb. He told me Ted used to sit for hours talking to him and a similar patient when no-one else came near them because of the stench from their faces. It was marvellous to see him and Ted together, Ted purring like a peacock - to mix metaphors - at the scarless handsome face that plastic surgery had wrought. ${ }^{337}$ McCullough later lived with Davin in Cairo while awaiting a court-martial for homosexuality.

1-2 We motored to Effingham and saw the nuns. ] Probably the nuns at St Teresa's school, Effingham.

14 Gordon House ] Winnie's lodgings in Lower Gordon Street, Camberley. 
with emphasis. Have been reading a good deal. Henri Bordeaux, | Zernatto, George Borrow's Wild Wales. Latter has much charm. George Sand: Mademoiselle la Quintinie. This book in its opening stages at least terribly boring. Preface more interesting, which can rarely be said. Am reading also Barchester Towers. Pleasantly surprised in Trollope.

If we don't leave too soon shall get four days off next weekend. Must spend one of them in Oxford.

Learn that a while back Leckie accused Sandy of wasting his time with a barmaid. Snobbish impudence. Such are the custodians of NZ social conventions. I probably stand high at the moment with the same man because of a photo and column in the Southland Times. The Southland Times!

Bitter cold but vigorous morning. This afternoon to visit Winnie and in hopes to get on with my story.

Rex continues his hairbreadth escapes.

\section{Tues. Dec 10}

Just in from 20 mile route march. Three nice names: Sweet Orchard, Silverspring and Trespasser's Cottage. Passed a gypsy camp. Their washing was everywhere drying on the bushes. A strange fruit.

McPhail and Brian Bassett are going off on an intelligence course.

3 terribly] t erribly TS $\mathbf{1 5}$ Silverspring ] Siverspring TS

1 Henri Bordeaux] Henri Bordeaux (1870-1963) French provincial and Catholic novelist.

1 Zernatto ] Guido Zernatto (1903-1943) A politician who had led the Austrian government's negotiations with Germany before the Anschluß.

1-2 George Borrow ] George Henry Borrow (1803-1881) English author. Wild Wales: Its People, Language and Scenery is a travel book describing a solitary walking tour through Wales in 1854; its author is heavily present, fond of digression and always in the right. The charm is probably in the distinction between the effect and what he believed the effect to be. 7 Leckie ] Douglas Farquharson Leckie (1897-1969) The commander of 23 Battalion, an Invercargill teacher and First World War veteran.

7 wasting his time with a barmaid] Thomas briefly mentions her (named Edna) in his memoirs; ${ }^{138}$ she was the daughter of the man who kept the Brown Jug. (Winnie Davin remembered how just before departure 'the New Zealanders had begun to sing "Now is the
[41]

Hour" in their favourite pub, the Little Brown Jug. ${ }^{139}$ ) A purported book review in the ship's magazine Men Lonely takes up the story:

"“Little Brown Jug." Thomas Sandy. This romance of young love and starcrossed lovers would have been more effective had the crude realism of the conclusion been present in the earlier episodes. ${ }^{140}$

9-10 a photo and column in the Southland Times ] No such article has been found, but a photo with a long caption appeared in the Evening Post in June 1940.

18 McPhail ] Edward Alan McPhail (1906-1967) Lieutenant in B Company, 23 Battalion, a bank clerk from Christchurch. 'He was one of those men whom you would never think of in peace-time as belligerent, as he took the tram day after day to his office, or on Saturday afternoons to play a reliable but unspectacular game of football. Yet in the war he had emerged quickly as a leader.' ${ }^{141}$ After serving as 5 Brigade's intelligence officer, he commanded 23 and then 21 Battalion. He remained a soldier after the war. 
Last night went to the pub where encountered Gordon Cunningham and Bond. With sudden revelation I saw that the latter is a very great bore.

Sandy's platoon were presented with $£_{5}$ by an old man along the road.

Last night stayed w Winnie till very late.

Mark Harvey it appears is a rabid anti-RC. How strange in this generation and how 5 much one can fail to perceive in a man.

As I came home an air raid alarm, siren very close and eerie.

Tomorrow the Duke of Gloucester comes and so I expect there will be great buggering about and the Leckie pest will descend on us in tongue of fire.

Tonight going out to Winnie's again perhaps to continue my story.

\section{Thurs Dec 12.}

Yesterday Gloucester's visit passed off without mishap though he was much cursed while the men stood in the cold.

[42] Today a CM saved me from the route march: not partic interesting, | plain AWL's. Had a drink w Cunningham and lunch at the Mandarin. Afternoon cold and depressed. Evening visited Winnie a little while and came back up here with her. Tomorrow Oxford.

Tuhan after shooting himself in the leg: 'had no idea the things were so sharp.'

Evans after Cptn Morten complained of badly cut lunch: 'You're in the army now, sir, you know.'

\section{Monday 16th Dec.}

4 Winnie till] Winnieitill TS 5 anti-RC] anti?RC TS 10 perhaps ] perhpas TS 18 the leg: ] th e leg; TS 19 Evans] Evenans TS 19 Cptn Morten] Captan Morton TS

3 Sandy's platoon were presented with $£_{5}$ ] As he tells it: ' $[. .$.$] a dark swarthy fellow, who, in a$ very foreign accent, asked "How many of zu are zere?" I thought perhaps he might be a fifth columnist of whom the good book warns, so said rather bleakly, "Ask yourself!"

Whereupon the blighter produced $£_{5}$ to shout the boys! ${ }^{142}$

4 Last night ] The order of this and the succeeding paragraph are reversed in the typescript: Davin adds the note '//To precede last para//' to its beginning.

8 Duke of Gloucester] Henry Duke of Gloucester (1900-1974) The King's brother; he was inspecting the New Zealanders in England. He was probably chosen for the role because of a very successful royal tour in 1934 .
14 plain AWL's. ] The new page of the typescript is headed 'Dec. 12 contd.' At the top, written by hand and crossed out, is '? where is previous page'.

18 Tuhan after shooting himself in the leg: 'had no idea the things were so sharp.' ] Not identified; there were no Tuhans in 22 or 23 Battalion. Bassett refers in passing to, sometime between the 9th and 17th, 'An inquiry into a fellow who had shot himself in the leg. As he was engaged to be married in ten days, self-infliction was suspected, but was finally disproved. ${ }^{143}$ The most likely candidate is Martin Sherrard Toon, a private in 23 Battalion who went AWL in Cape Town on the journey out. ${ }^{144}$ However, he was unmarried at his 1946 death. 
Friday went down to Oxford: maddeningly slow trains: changes at Reading and Didcot: crowds, delay, confusion. Still, delighted to see Oxford again; as I seldom was when up there. First person I met was Beck, on sick leave fr some very hush hush war job. Thence to Balliol: where Cyril and I were cordial to each other. Lunch at Rhodes 5 House: Allens very sad about Lothian's death. CK looked old and worn: had had very little sleep because of the long raids of the full moon. Lovelock was there, convalescent from concussion. After lunch some soldiers appeared to play monopoly; I excluded myself on the ground that the game brought out the worst in people and I wasn't bad enough to be good at it.

3-4 fr some very hush hush war job. ] from some hush-hush [war] job. TS 4 Balliol: where ] Balliol, where TS 4 to] with TS 8 people] peope TS

3 Beck] Leslie Beck (1906-1978) A former Jesuit who became a philosopher at Magdalen; his hush-hush job was as head of the French section of the Political Warfare Executive. ${ }^{145}$ 4 Cyril ] Probably Cyril King, the Balliol porter, since Davin uses his first name. ${ }^{146}$ Alternatively, Cyril Bailey, a classicist Fellow. 5 Lothian ] Philip Kerr (1882-1940) 11th Marquess of Lothian. The British Ambassador to the United States; Allen knew him because he was Secretary to the Rhodes Trust from 1925 to 1939 .

5 CK ] Carleton Kemp 'CK' Allen (1887-1966) A legal academic at Oxford who was Warden of Rhodes House and thus had been responsible for Davin's pastoral care. Davin remembered him with affection, especially for arranging that Winnie Davin could stay with him while pregnant with Anna. 6 Lovelock] John Edward 'Jack' Lovelock (1910-1949) Rhodes Scholar, runner and doctor. The subject of James McNeish's novel Lovelock. His performance at the Berlin Olympics in 1936 was enormously famous at the time; some idea of his significance to New Zealanders then can be given by a story probably, sadly, apocryphal: 'So help me, the English Army in the desperate days of 1942 had a "Good Conduct Officer", a major, walking the streets of Cairo looking for unsuspecting soldiers breaking Army Rules and Regulations.

A Maori soldier didn't salute him. Gad sir! "Aren't you in the habit of saluting officers?" "No!"

"Take five paces back and walk towards me, saluting as you come."

Looking at the major's grey hairs, the Maori replied:

"Not even Jack Lovelock would give me five yards start"

True enough, in a flash the man from Aotearoa was vanishing behind Shepheard's Hotel sixty yards away. ${ }^{147}$

6-7 convalescent from concussion. ] Lovelock had fallen from a horse in September 1940 and was unconscious for two days. 
On way to Cobb's met Bleakly and we drank a couple at the King's Arms. He is very reserved but I was delighted not so much at meeting him by chance as by being back where one met people by chance. Permitted myself a brief scrutiny of Blackwell's but did not risk the expense of an entry.

Finally found Cobb in the Bodleian where a little boy garbled my message: an Australian called Captain Duffy wishes to see you. Cobb's perplexity changed gratifyingly to pleasure. He waved his thin arms about strangely and looked like a jubilant man fr Edgar Allan Poe. The Fall of the House of Usher, or that woman who draws spidery people in the New Yorker. We appointed for the Lamb and Flag at six.

On to Ghiselin's digs: out but his thesis open and words like apperception stared up at me with unblinking reminder of Kant. The walls covered in prints in strange medley: the medley of a New Worlder, who loves art in a non-European way, forgetting the obligation of genuine taste to hate and to have a personal pattern of preference.

Outside met Ghiselin in the High: made him come to tea with me at Beck's. There we held Oxford discourse for one hour or two, languid in manner, incisive in method, of men, affairs, politics and personalities, philosophers and philosophy. Beck becoming very Tory: a dangerous man because always prepared to concretise logic in action, and ruthlessly logical. Ursula very charming. Ghiselin slightly intimidated because Beck is his supervisor and $\therefore$ G. although a good brain in his own right inclines to believe too 1 Bleakly] Bleakly[(?)] TS 3 people] peopke TS 7 fr] from TS 8 Poe. The] Poe. - the TS $19 \therefore$ G.] therefore Gh. TS 19 believe ] beieve TS

1 Cobb ] Richard Charles Cobb (1917-1996) A friend of Davin's at Merton. He became a prominent historian of France, with a particularly engaging style, but is now perhaps best remembered, if at all - a recent review of his letters to Hugh Trevor-Roper opens plaintively 'Who now, other than historians of modern France, remembers Richard Cobb? ${ }^{148}$ for his shambolic eccentricity and remarkable enjoyment of life as what Le Monde called 'l'une des figures les plus excentriques du monde universitaire'. ${ }^{149}$ Skinner's review elicited a strongly-worded reply from Keith Ovenden with some mentions of Cobb's gossiping, alcoholism and greed, saying that 'It is typical of Cobb's manipulative self-promotion that he should claim friendships in the bohemian worlds of the very different figures of Dylan Thomas, Julian MacLaren-Ross and Louis MacNeice, who were all friends of Dan and Winnie Davin, and whom Cobb might have encountered at the Davins' house in Oxford on the occasions when he turned up from Wales demanding a bed for the weekend - a convenient friendship quickly forgotten once he had his Oxford fellowship.' This does not seem quite fair. Cobb himself haunted Soho, where all these figures congregated; and he continued to meet and talk with Davin; his letters do fall away, if only slightly, once he arrived in Oxford, but this can perhaps be explained by his living in Oxford. 1 Bleakly] Maurice Cameron Bleakly (1909-1989) The only Bleakly Davin might plausibly have known in Oxford. He came from Southland and had been at Otago at the same time as Davin. He then went to Oxford in late 1939 intending to study for a doctorate in zoology. He was commissioned into the English army in 1941; after the war, he lectured for many years at the University of Queensland. 3 Blackwell's ] A prominent Oxford bookshop, located in Broad Street.

8-9 that woman who draws spidery people in the New Yorker ] Probably Barbara Shermund (1899-1978); possibly Peggy Bacon (1895-1987). 10 Ghiselin ] Richard Sommerville 'Dick' Ghiselin (1914-1943) Canadian student, from the University of Alberta, at University College. 18 Ursula ] Ursula Beck (1909-1968) Leslie Beck's wife, the daughter of Harold Joachim. 
readily other brains are better. Like all these modern disciple types he has | the Boswell trick of bringing the conversation always to serious topics: I incline to regard talk as an end itself and have little faith in the utility of argument.

Towards six we leave and go along the High through the gathering dark as so 5 often, I still glowing with the pleasant warmth of these Becks, their comfortable culture and quiet brains, their good fire, good tea, their cat and their unemotional commonsense. Also their fondness for me as a relative swashbuckler, man of beer and feckless adventure, child of providence sometimes spoiled and sometimes impatient chastened, stimulated by their quietness to extravagance and paradox.

At the Lamb and Flag we find Cobb, glowing already at the thought of beer to come and great talkings. Schull Arms comes in and drinks a while with us, solving before he goes the problem of my night with his latch-key and directions to the spare bed.

We warm to our beer and make our plans. At 7.15 Cobb and I to Merton and to dinner, Ghiselin to Univ to find his friend Gollay.

At Merton we eat well and drink high, Cobb stimulated into typical hostility by strangers in the hall, scholarship sitters and comparative freshers, living insults to his

3 itself] in itself TS 4 and] [and] TS $\mathbf{1 3}$ Merton] Merto n TS

1-2 the Boswell trick] This page of the typescript is headed ' 16 Dec, contd.' 2 bringing the conversation always to serious topics ] That is Ghiselin talks to Beck like James Boswell steering Dr. Johnson away from levity. But see also Boswell's remarks on this subject: 'When I complained of having dined at a splendid table without hearing one sentence of conversation worthy of being remembered, he said, "Sir, there seldom is any such conversation." Boswell: "Why then meet at table?" Johnson: "Why, to eat and drink together, and to promote kindness; and, Sir, this is better done when there is no solid conversation; for when there is, people differ in opinion, and get into bad humour, or some of the company who are not capable of such conversation, are left out, and feel themselves uneasy."'"150

11 Schull Arms ] Henry Shull Arms (1912-1972) An American Rhodes Scholar at the same time as Davin 'who combined the physique of a lumberjack with a subtle mind and great skill in assembling extremely delicate instruments; ${ }^{151}$ he had been at Jesus College and was universally known as Shull. As far as Davin knew, at this time he was working at the Clarendon laboratory and examining ways of
[43]

using magnets to extract shrapnel in neurosurgery. In fact, his career had just taken an interesting turn. He became involved in the secret British research into nuclear weapons, working on methods of gas diffusion of uranium. This developed into a post-war career in the development of British nuclear power.

14 Univ] University College.

14 Gollay] John Ford 'Jack' Golay

(1918-1969) American Rhodes Scholar at University College. He became a historian at the University of West Virginia. Gilbert A. Harrison, who lived with him during the Berlin Airlift remembered 'Golay, who had been the editor of the Daily Trojan at USC, had gone to Oxford, and after Oxford worked for Lord Beaverbrook and had an important part in the writing of that famous Beaverbrook Report on - was it national health insurance? Jack Golay was nervous, introspective, quick, morose, way up or way down [...] and I did not know until many years later when I met Jack back in the United States that he suffered from bouts of melancholy which in the end proved much too much and he killed himself. ${ }^{, 152}$ Golay worked for Lord Beveridge, not Beaverbrook, as his secretary; it is the Beveridge Report to which Harrison refers. 
six years' tenure, men admiring uncritically the [Merton] that he terms inhospitable and grudgingly loves. Two of them sit opposite to us:

$1^{\text {st }}$ Innocent: What are you doing tonight, old man?

$2^{\text {nd }}$ Innocent: I thought I would walk to the Isis and take a pint of ale. Would you care to come.

$1^{\text {st }}$ I.: A terrible night, old man. I think I shall sit in Merton and drink.

$2^{\text {nd }}$ I.: I like walking in these nights. Last night I went to the Perch for my pint.

Cobb and I look at each other and smile. True lovers of beer do not waste opening times on such distances. We outline to each other our plans, both pleased with our superior sophistication, I conscious that, as a soldier, as a NZer, as an Oxford man of old establishment, and a drinker of unquestionable status I intimidate these self-conscious boys; Cobb elated because tonight he does not have to face them alone and their affront of newness to the old memories of this hall.

We move to the Eastgate, away from the new pipes, the uneasiness of boys and the slight melancholy of remembering Guy and Espey and Mike and many others who once dined here.

At the Eastgate we find Ghiselin and Gollay. Gollay is young and humbly arrogant, humble because young and because it is a puritan fashion, arrogant because an economist, and a communist, and we are mere dilettanti, pleasant but cowards unwilling to accept that obvious materialist gospel which like Xianity has been so intolerant for love of mankind. Cobb in high fettle departs to do battle with Dean Jones.

[44] He might be sent down for in the / extravagance of hate for new men and new things last night he got drunk with violence and abandon.

Hostile vaguely I remain, enjoying the pleasures of teasing the faithful with eulogies of Trotsky, scepticism of perfectibility, terror of perfection.

They drink sparingly, I heavily, to counterbalance the aridity of political Puritanism emanating from the pure in mind.

1 uncritically] uncriticically TS $33^{\text {st }}$ ] First TS $\left.44^{2^{\text {nd }}}\right]$ Second TS 5 come.] come? TS $\quad \mathbf{6}^{1^{\text {st }}}$ I.: ] 1st I.: TS $72^{\text {nd }}$ I.: ] 2 nd I. TS 9 times on ] time son TS 17 find Ghiselin ] finf Dhiselin TS 25 perfection.] perfection.. TS

14 the new pipes ] A pun on the high voices of the young, and the new pipes of beer they will be drinking.

15 Espey] John Jenkins Espey (1913-200o) An Oxford friend; 'He was the son of Presbyterian missionaries to China and had been a Rhodes Scholar. ${ }^{353}$ Although he taught at UCLA for many years, specialising in Ezra Pound, he became best-known for his comic writing about his childhood. ${ }^{154}$

15 Mike ] Michael Kennedy 'Mike' Joseph (1914-1981) A New Zealander who had been at school with Davin. After serving in the ranks of the British army as an artilleryman, he returned to become an academic, poet and novelist at the University of Auckland. Before the war, he was also Davin's contemporary at Oxford; although he did not receive an overseas scholarship, wealthy relatives paid for his study, and James Liston, the Catholic bishop of Auckland, ensured his entry into Merton, and thus acceptance by the university: 'It was he who wrote to Merton on my behalf, signing himself (as he was entitled to) "Bishop of Auckland". And to old Bowman [the Warden of Merton, a 'difficult and cantankerous old man'] this could mean only an Anglican bishop: at once, the gates of Merton were magically opened to me. ${ }^{155}$ 21 Dean Jones ] Idris Deane Jones (1899-1947) Senior Tutor at Merton; he went by the name I. Deane Jones. 
The pub closes. I buy beer and we move to Ghiselin's digs. Cobb does not appear and I become uneasy. These men are not mad enough for me. Where is Cobb. Ibecome slightly rude. It is midnight and I go. I roam the old streets for a while, gloomy as to old days gone and the passing of friends, seeking Cobb, hungry for talk and adventure, 5 an inebriated revenant.

At last I go to Museum Street. The bed is perfect: a Platonic form of a bed: it is a shame to sleep in such a bed. One should lie awake and contemplate the effortlessness of its support. It is a wife, not a bed. I smoke a cigarette and read T.S. Eliot. And so to sleep.

In the morning I awake and lie

Dead city where the dead live coldly and the living mourn, You plucked my thought from a passing train and like the flowers It lingers fading on your dark drab pathos.

in the dark contemplating my comfort. Schull wakes me. I rise and bathe, the bath is not hot enough. Breakfast, good but not quite the bacon and eggs I had promised myself. Beautiful coffee but my slightly bemused state would prefer tea. I have difficulty in expressing myself: it is a labour to form a sentence. Penalty for the night's easy eloquence. Nan makes me uneasy. She is comparing me with her husband: I am embarrassed by tacit criticism, and his captive state. To this we come, that we are husbands.

Continued w next books

\section{DMD: DIARY B. Dec, 1940 - May}

\section{1.}

[copying begun 4 Feb 79.]

2 is Cobb.] is Cobb? TS 4 old] the old TS $\mathbf{6}$ Museum] Mueum TS 14 bathe] bath TS 16 coffee ] coffeee TS 21 Continued w next books ] [/// End of 8 Sep - 16 Dec 1940 notebook.///] TS

11 Dead city] This stanza of verse is transferred to the end of the paragraph in the typescript.

18 Nan ] Nancy 'Nan’ Arms (1913-1988) Shull Arms' wife.
21 Continued w next books] At this point, the typescript continues but the original volume of the diary is missing. All alterations to the text following are editorial corrections. 


\section{Dec, contd.}

At ten we go out: I go down the Turl to the Bank, deposit $£$, take out $£ 6$. At last my overdraught is paid. I send two cables. I am overcharged but cannot object because I was so angry before with a woman who kept everyone waiting with arguments.

I go to College and make an appointment with the Master for 12.

Thence to Elliston's where I find Cobb and we take coffee: Brian Ireland comes in and we hold his table for him till he returns with a very attractive girl whom he avoids introducing to us.

A man comes up to me whose face I know well but whose name I've forgotten. $\mathrm{He}$ says he knows my face but has forgotten my name. He is an officer in the Cheshires. We feel that we must have known each other well but can't remember where. He was at Keble. Then we discover that for three years we attended the same lectures: thus though we had never spoken we had had the illusion from familiarity that we had been friends and it was left to our first meeting to discover that we were not. This man also was on embarkation leave.

At 12 Cobb goes to the Grapes, I to interview the Master. I begin with goodbye and a request for advice re after the war. We discuss the Commonwealth and All Souls. He is cautious but encouraging. I glide to army education: but it is plain that he cannot help so we leave the subject before I become directly committed.

Back to the Grapes where the barmaid recognises me with surprise and asks after Mark. I tell her what I have just learnt myself: he is in the army. It is a comi-tragic thought; yet it may give him years more life.

At one I return to lunch with the Arms, Cobb to sleep at the Union.

The lunch is splendid: a pheasant shot by Schull (who is becoming v. pukka, says Nan, pretending to laugh at him. But it is a change of her making.) We have a bottle of Beaujolais: I have not much palate, and it is little more than vin ordinaire: but it is a reminder of Paris in the old days and it is a gesture from them. We speak of the night of Heugh's party, that night which unbeknown to me and never since explained must have held a quarrel to explain the six months' estrangement. They are on the verge of explaining but I am embarrassed and unsupple. I help them away from the point before

6 find] fine $\mathbf{1 7}$ All Souls] All souls 24 Schull (who] Schull (who 24 says] says,

2 the Turl] Colloquial name for Turl Street. 5 the Master] Alexander Dunlop 'Sandy' Lindsay (1879-1952) The Master of Balliol; a political philosopher with an interest in adult education. He was a patron of Davin's. Davin also supported him in the famous Oxford by-election of 1938 when he stood as the unity anti-appeasement candidate.

6 Elliston's ] Barbara Pym uses the same abbreviation throughout her novels for Elliston and Cavell, an Oxford department store with an incorporated café.

6 Brian Ireland] Not identified.
21 Mark] Not identified; not Mark McClung, who was in the Canadian Navy. 23 the Union] The Oxford Union, the debating society. 28 Heugh ] Robert John Heugh 'Bulldog' Drummond (1913-1943) A New Zealander who had been at Balliol at the same time as Davin; they were then at OCTU together. He transferred to the air force and was killed; Winnie remembered that for her and Davin, 'his death was to be one of the greatest personal griefs the war brought to us. ${ }^{356}$ 
it is reached. But Schull says he was drunk that night and jealous of the flow of my talk. That is a clue, though I think that the truth was that Nan was jealous for him: she has that accursed female ambition for husbandly preeminence and aggrandisement.

But the meal is very good and after it we go Xmas shopping. I buy two pairs of silk 5 stockings for Winnie and nearly buy her a pair of boots: they have not the size. We visit also Walters' and Halls where I pay $£_{2}$ on my bill. I feel very gay and almost like shopping. At 3.30 I leave them to waken Cobb. As I pass down Ship Street I remember Mary Stanley Smith. I call and she is delighted to see me and we discuss old times. I fetch Cobb and a cake and we

\section{Dec contd.}

have tea. Cobb is delighted with the queerness of her pandas, her voice and her strange circle of 'willowy' Oxford boys.

I leave to catch a train; but it is growing dark, and the thought of trains affronts me and I would like another night. So I get another room at Cobb's, we drink at the Lamb and Flag and Wheatsheaf and dine on chicken at Merton washing it down with good Merton beer. Later we drink in somebody's room and are flattered and pestered by a sensual cat.

We decide to go to the Gardener's Arms but go to the Lamb and Flag first. We leave there at 9.15 too late for GA. So go to Clarendon Arms. There till 10.45, Cobb with the hiccups and I curing him by holding his nose and pouring sodawater down his mouth. An unpleasant fellow from Merton is there, much hated of Cobb. He sends us pints, I return him a half. He becomes drunk and is at last led out by the landlady like a little boy being taken home. Cobb gets lost looking for the lavatory and blunders into a daughter's bedroom from which he is rudely expelled.

\begin{tabular}{|c|c|}
\hline 4 shopping] shoppoing 4 pairs] pair & asd 20 go to ] goto 24 the ] athe \\
\hline 6 Walters'] A tailor's in Turl Street. & 12 the queerness of her pandas ] The meaning \\
\hline 8 Mary Stanley Smith ] Mary Constance & of this is unclear. \\
\hline Stanley-Smith (1903-2002) The Oxfordshire & 19 We decide to go to the Gardener's Arms \\
\hline county librarian for half a century; she lived at & but go to the Lamb and Flag first. ] Clearly a \\
\hline number 12, Ship Street. It is not clear how & common path: returning to Oxford in 1976 \\
\hline Davin knew her, but the publisher Christopher & Gordon Craig, 'a small, white-haired \\
\hline Hurst remembered how (some years after & American' who was a friend of Davin's, ${ }^{158}$ \\
\hline Davin's time) 'Each Sunday she dispensed & recalled 'The Horse and Jockey, The Royal Oak \\
\hline mugs of tea and pieces of cake to - as my & and The Lamb and Flag, at each of which Dan \\
\hline friend A. remarked after his only visit - young & Davin, Mark McClung, John Garrett [...] and I \\
\hline men in need of a mother figure. ${ }^{157}$ These & used to stop briefly during our Thursday \\
\hline Sunday afternoon parties seem to have been & evening pub crawls before proceeding to our \\
\hline attended by a remarkable range of Oxford & final destination, The Gardener's Arms in \\
\hline students; odd references appear in several & Plantation Road. ${ }^{, 159}$ \\
\hline
\end{tabular}
memoirs and biographies. 
We move on to the Randolph: I persuade us double whiskeys and a black coffee for Cobb. But he is so rapt in an oration in French purporting to be by Pierre Laval that I drink his coffee. I flatter the waiter who is eccentric and fond of Cobb, wheedle more whiskey and four bottles of beer. We move to Mary's where we drink the beer and Cobb goes to sleep. With great difficulty I carry him out and so back to St John Street.

In the morning we catch the 1030 to Reading after a voluptuous bath.

Cobb lends me his short stories. We part at Reading and I lunch on roast pork, beer and the stories which are extremely good: of the school of Maupassant, Maugham, Waugh, Isherwood and Cobb. Mostly of Paris, vital, easy, and alive.

Full of hates and loves, but about neither. Very impressive.

By three back in Camberley with my booty of tale and adventure. I read the stories to Winnie: he wrote 25 one after the other. And so to bed.

Today bacon and eggs in bed and the whole morning. This afternoon reading, playing with the baby and writing this. Tonight perhaps my own story.

\section{Thurs. Dec. 19th.}

Today a route march of twenty miles, covered without sight or event of note.

Yesterday bought tropical things and compelled once more to broach a small overdraft. In the afternoon went to Winnie's in high hopes of getting on with my story; but an accursed inertia has overtaken me. I read all the afternoon. After an excellent dinner I was coaxing myself into the right humour when the baby howled and dashed me. What a diabolical sound. I know nothing more hideous. Calculated I suppose to see that a baby's incapacity for movement is compensated by power to attract attention and enforce inquiry into the cause and effort to relieve pain it ruins my temper for hours. Again

\section{Dec contd.}

at night when we went to bed a short interval of the same performance. By a pleasant talk I had got back to good humour but this too was destroyed. Went to sleep very gloomy and awoke likewise.

Tonight I must stay in on duty and so will make another attempt.

But first some points arising out of the novel I read yesterday and the conversation Winnie and I had [upon] it lest I forget what may be helpful.

The problem was why the book (These Foolish Things: Michael Sadleir) while obviously written by a man of some taste was nevertheless inferior. In fact, the problem 2 French] Frech

2 Pierre Laval] Pierre Laval (1883-1945) Former Prime Minister of France who had chosen to collaborate as a senior member of the Vichy government; he accepted a post as Minister of Foreign Affairs, and later became prime minister again. He was executed after the liberation.

33 Michael Sadleir] Michael Sadleir (1888-1957) British novelist (and James Courage's publisher). In These Foolish Things (1937), Nicholas, a British diplomat, describes his love affairs in the 1920 s and 30 . 
of the second-rate. One usually passes the verdict but does not stay to analyse. De gustibus and yet what is literary criticism but a long disputation about taste and an attempt to bring permanent criteria into a welter of personal prejudice. And this is the virtue of the inferior book that by stopping to find out what is the matter one may learn more than from a better book whose faults do not provoke question.

Individual and particular to this book was the fact that while it set out to question convention or at least by implication defied it, it rested for its tragic situation upon a convention that remained unquestioned. But this inconsistency seemed to me only part of a deeper inconsistency.

The clue lay in the first chapter which irritated me so much that I almost abandoned the whole book. Why? I did not know at first but think I found out. The sense of falseness one had was due to the failure of the author to find an effective compromise between realism of scene and the mood. Now even realism is misleading because any writing at all requires selection. The problem of realism considered singly is how to select detail which give the sense of realness i.e. how to be a selector and yet get across the impression of life, when life works according to a pattern alien to art, or at least a pattern diffuse, infinite unlike the limited pattern of the novel. The details life selects for happening are of a fulness and apparent arbitrariness irrelevant to the limited pattern of the novel They are relevant to the completely explicit pattern of eternity. They are part of the novel of God. The novelist works in a limited compass: he is dealing only with an episode in the novel of God.

Even as far as this then his task is difficult if he wishes to avoid an arid chronicle of irrelevancies on the one hand and an obvious fairy tale on the other. But that is not all.

He has to be an impressionist as well. That is to say he wishes to convey an emotional setting, not merely by the bald statement that it existed but by subtle implication such that an emotion cognate to the one he wishes to describe is aroused in the reader. It is from such conscious or unconscious intention that the cruder forms of pathetic fallacy derive. At its most successful we have Lear in the storm, at its worst Victorian melodrama, the unmarried mother, the harsh father, the doorstep and the snowstorm.

3 welter] weleter 4 out what] outwhat $\mathbf{1 2}$ the author ] $t$ the author

1 One usually passes the verdict but does not stay to analyse ] Perhaps a reference to Bacon's jesting Pilate, who asked What is truth? 'and would not stay for an answer.' ${ }^{160}$ 1-2 De gustibus ] An abbreviation of $D e$ gustibus non disputandum est: there is no disputing taste.

17-19 The details... pattern of the novel ] . This is perhaps a response to John Buchan's argument (set up for rebuttal) that 'They thought it their business to tell a story, but to tell a story is to shape existence into an arbitrary pattern for which there is no warrant. ${ }^{161}$ See Davin's reference to Buchan in his entry for May 8, 1941. (p. 103) 24-26 That is to say... in the reader ] In other words, as Eliot put it: 'such that when the external facts, which must terminate in sensory experience, are given, the emotion is immediately evoked. ${ }^{362}$ 


\section{Dec contd.}

But both these instances provide the connection between the two tasks. Lear is successful because language and external circumstance are worthy of each other. Emotion, weather, internal situation and language correspond.

Out of this difficulty proceed two extremes of badness: on the one hand bald, arid writing realistic as the minutes of a meeting - Zola and Flaubert at their worst; on the other sheer romanticism where emotion is all and we wallow in a quagmire of lushness - George Sand.

And again it is possible to try and effect the marriage but fail (a) by selecting a hackneyed [emotional] symbolism and (b) by choosing a language of realism that clashes with the symbolism.

Thus by a single word 'ex-lover' Sadleir destroys a paragraph, by a single phrase 'nothing mattered any more' degrades a page.

And such inconsistencies saturating a novel destroy the whole.

This brings me to a second difficulty more tough in solution. How is the writer to convey the thoughts of his protagonists: this seems to be the central problem of the modern novelist. Hemingway attempts to solve it by the relation of the circumstances and then by bald conversation in understatement leaving the reader to read into and between the lines their emotion. At its best very successful, at the worst bathetic. Joyce attempts the stream of consciousness. Both are trying to avoid the 'he thought...' method and the 'what was he to do now?' method, too crude and too wearisome in their iteration, the second a slight advance on the first. Hemingway abandons the whole machinery, Joyce carries it a step further. For not only is it a problem of expressing it is a problem of selecting and the latter part Hemingway certainly shuns.

The development of Joyce's novels shows clearly the difficulty: on what basis is the selection to be made? If one is to be realistic at all one must acknowledge that the consciousness world contains as many bizarre thought events as the external world happenings. If the problem arises for the Flauberts how much more crucial it is for the Joyces. And not only is there the conscious chaos, there is the unconscious interacting with the first.

Joyce manfully faces up to it: in the Portrait his selection never ceases to be intelligible: in Ulysses it is still for the most part intelligible. In Work in Progress like a true logician he has recognised that the contents of a private mind even when expressed as fully as possible remain private, i.e. unintelligible. He has given up intelligibility, retaining only wit and euphony. No doubt a selection does exist: but alas we encounter the paradox that in pursuit of realism he has arrived at a private reality so private that we are no longer able to compare art with the original and therefore cannot judge the success of the realism.

5 of] if 6 Zola and ] Zolaand 22 advance] dvance 26 to] to 26 all one ] allone 
The problem inverts the tag: ars brevis vita longa: and we are left with the difficulty how to express the whole in the part, when that part must itself be a whole and what new conventions of selection of events

\section{Dec 1940 contd.}

and of language we are to adopt: but we are left with the mortifying fact that whatever we do hit upon will still be a convention and life will still have different logics however hard we try to assimilate them.

\section{Saturday Dec 21}

Yesterday afternoon went to Winnie's, had headache and was very dull. Winnie also gloomy, because of me and because the baby not feeling too well. Read Trollope but to my mood he seemed tedious and trivial. Later felt so sorry for Winnie that I made an effort out of my slough and we became happier. Went to the Brown Jug for a little while and talked [very] pleasantly. 'He was so sensible that he had only to express a profound and original thought for it to become a commonplace.'

Getting back early found Manson returned. Talked to him for remainder of evening and supped off a cake sent me by anonymous Xmas benefactors of Otago.

A card from Geoffrey: Fouquet's Madonna and Child, a beautiful thing whose original we saw in Paris exposition along with Geoff. It was the day we saw the beautiful

14 to express ] toexpress

1 ars brevis vita longa ] An inversion of ars longa, vita brevis: Davin says, reversing the familiar Latin translation of Hippocrates, that art is short and life is long.

519 Dec 1940 contd. ] At the top of this page in the typescript, Davin has written ' $\mathrm{K}$. Sinclair'.

6-8 But we are left... try to assimilate them ] It is worth mentioning that despite this criticism Davin's writing was much influenced by Joyce, with speech patterns 'closer to Joycean turns of phrase and cadence' than Frank Sargeson. ${ }^{163}$ Compare, for example, the mental fight over a green or maroon pencil in 'The Apostate' to the conflict between green and maroon in A Portrait of the Artist as a Young Man. Much later, Davin would argue that this problem was solved by Anthony Powell, by arguing that the consequence of a 'world of uncertain knowledge, whether of ourselves or others' is the rejection of 'the technique that James Joyce imposed': internal monologue requires knowledge of at least one mind, but all we have are sympathy and observation. In other words, with a narrator who only observes and will 'never explain to us how people feel', we do not need to know, only, through the veil of our limitations, suspect and sympathise. ${ }^{164}$

14-15 He was so sensible that he had only to express a profound and original thought for it to become a commonplace.] This quotation has no obvious source; it is likely a planned phrase for a story or essay on Trollope. 18-19 Fouquet's Madonna and Child ... in Paris exposition ] The right wing of his Melun Diptych; normally kept in Antwerp, it had been sent to Paris for the 1937 Exposition as part of an exhibition of 'Chefs-d'œuvre de l'Art Français'. ${ }^{165}$

19 Geoff] Geoffrey Cox (1910-2008) A friend of Davin's; he had met him briefly at Otago, where he knew Winnie well, then again in 
woman with magnificent eyelashes in the Van Gogh exhibition. A good day it was, such as come seldom now.

This morning went down and castigated Alkits for being rude to my batman when he went to fetch a parcel.

\section{Sunday Dec 22nd.}

Epitaph for Last Winter's Snow.

Under the snow like a dead ghost lies the land.

Mourning, we pass with muffled tread.

Grief for the dead earth joins with dearer griefs;

This dead buried many dead.

Like sheep on the cold hill waiting for the dawn

We yearn for the grass and the sun;

But even the green earth yields up no dead

Its final embrace has won.

Under the snow in heart's winter chill and numb

Our people brood too long their dead;

Let rage like spring their winding-sheet

Dissolve and flower in hope's blood red.

\section{Sunday Dec 29th.}

Hard to write today because the billet is loud with intimations of departure. We leave on Friday. Xmas came and went without much note: painful Xmas dinner because officers became mess orderlies and such occasions which call for spontaneous clowning find me self-conscious and wanting. Winnie presented me with a travelling chess set which may help lighten the tedium of our voyage. Poor Frog, when will I see her and Anna again. Have bought Italian and modern Greek grammars to pass the time. Modern Greek much more like the ancient than I expected so I have a fair start. News of Mike and Heugh: I shall leave all my good friends behind and shall have no more good

$\mathbf{1 8}$ hope's] hop's $\mathbf{2 5}$ grammars] gramm rs

Paris before the outbreak of war, when he was serving as the Daily Express bureau chief after a rapidly successful career as a foreign correspondent. During the war he was successively an intelligence officer, diplomat, and intelligence officer again. He then played an important part in the development of television news at ITV. According to Davin, 'He had the former journalist's gift of knowing everyone of interest and mental speed, agility and the liveliness of contradiction encouraged by Oxford where he had preceded me as a Rhodes Scholar. ${ }^{366}$

3 Alkits ] Probably a local branch of Alkit Ltd., London tailors who specialised in military kit. (There was no officer in the New Zealand Division named Alkits.) They had branches at Aldershot and Camberley. Davin is probably referring to the Camberley branch.

10 This dead buried many dead. ] c.f. Luke 9:60, Matthew 8:22. 
conversations for many a day, if any. (Think I have discovered why my compatriots are so intriguing and ambitious. They have nothing but personalities to think about and

\section{Sunday Dec 29th contd.}

consequently no objective approach even to these.) But perhaps I shall find some old friends in Egypt.

Tomorrow to Godalming for a C.M., defending Murphy, an indefensible. Today I feel gloomy at the prospect of being shut up among nice men but petty thinkers. What a fool I was having once escaped NZ to join its military projection: where automatically I am without honour, such gifts as I have being unappreciated or rather unseen: for our people are colour-blind to the abstract and with them 'artist' is a term of derision: they see the madness of the artist, never the artistry of the madman. In parts this battalion is a travelling Invercargill, a peregrinating small town, pullulant with pettiness and impregnable in the complacencies of its provinciality.

Still, there will be new towns to see, new scenes and new suns. I have been too long in England.

NB (1) Story: NZ bourgeois girl: complication of opposing snobberies, difficulties.

(2) Two friends toss for God.

(3) Scene where two memories meet: Ellistons.

(4) Contrast between Mary's keen, knife face and warm Northern accent.

Read some Priestley the other day: an attractive writer better phraser than I gave him credit for being. Animated in company, gloomy alone.

\section{DMD's DIARY 1941. Began copying 25 March. 1979}

\section{Thurs. Jan 9th. 1941.}

New Year came with the fairly certain news that we were to leave on the $3 \mathrm{rd}$. Winnie was splendid and we were even happy right up to the hour of parting, through her control. How well she knows my hatred of tears, and almost English embarrassment

429 th ] 29 th

7 Murphy] Not identified. There were three Murphys in 23 Battalion.
18 Two friends toss for God.] See note on p. 83 . 
at a 'scene' even without a public. It was sad to go, to leave her and little Anna but these partings keep love taut and refreshed and though it is terrible to embark upon a change, change preserves.

I shall long remember that march out of Camberley, in the early night, the men too heavily loaded but glad to be again on the move, the anonymous goodbyes cried from the dark, the people at their doors, not framed in light as in peacetime but merely pale vague interruptions of the shadow. And the men called back to them and whistled as they marched through the night along the road to Farnborough. The moon was new and high, the night clear and occasionally away to the flank we could hear the AA guns, or the reverberant boom of a bomb. So New Zealand said goodbye to Camberley and I passed for a while and perhaps for ever from the life of Winnie and Anna.

At last the men were all entrained: Rex and I were together, with half a bottle of whisky. We played chess till early morning. The night was terribly cold: we warmed our feet on each other's bottoms and we tried to sleep. The worst night since the one we spent on the downs, and almost as little sleep. Morning Lancashire was quilted with snow. Rex leaned out of the window at Warrington and gave a sort of muttered shout in greeting to his past.

We embarked about one on the Saturday: a good ship, the Athlone Castle, still much scarred from her last trip, 25,000 [(tons)] and the flagship of her convoy. My spirits rose almost immediately: not that I am aware much of excitement at ships and the sea, though it must be that.

On Saturday night borrowed 10/- from Ron Stewart: found Hawksworth was on board and after many brandies had hot disputes with Stewart on his account. Neither Hawksworth nor I have otherwise acknowledged each other's existence. Some day my chance will come for my final settlement with him.

On board are the Maori Bn., FE and FA and ourselves. The Maoris impress me very favourably with their keen alive faces, their discipline, good humour and the poise that comes from their culture and their pride. Our pride is uncouth and without spirit.

The food is excellent. How much Winnie would have enjoyed it. It is those with the power to appreciate who really deserve.

12 At ] AAt 18 Castle] Castlle

16-17 a sort of muttered shout in greeting to his past.] King was born in New Zealand; however, before the war he was a prominent rugby league player, and toured England as one of the Kiwis team. Although no tests were played, Warrington is a centre of rugby league. 22 Ron Stewart ] Ronald Swanson 'Ron' Stewart (1906-1983) 23 Battalion's medical officer, a general practitioner from Gore. He stayed behind to treat the wounded on Crete and was captured; after release, he went on to postgraduate study in England before returning to Gore. ${ }^{167}$

22 Hawksworth] William 'Bill' Hawksworth
(1911-1966) Another Otago student, now a doctor. Davin seems to have blamed him for his failure to get a Rhodes scholarship on his first attempt. He enlisted in England, where he had been working in Sheffield. During the war, he was commander of the 6th New Zealand Field Ambulance. He then returned to England, living at Boars Hill in a house called Haeremai and working in Oxford as an obstetrician and gynaecologist. 26 Maori Bn., FE and FA ] Maori Battalion, (5 Company) Field Engineers and (B Company 5) Field Ambulance. There were some 1480 soldiers in total. 
The Australians have taken Bardia with great dash and are now before Tobruk. As we go via Capetown we shall be a long time arriving - if we arrive at all.

The men are very well quartered, in some cases better than the

\section{Jan contd.}

officers themselves.

I have found a man closer to my kind than any yet in the NZEF; oddly enough, a Catholic padre. He was at Mosgiel where he admired Morkane - and at Rome. Later he was at AUC and subsequently worked among the Maoris. He is fond of beer, an excellent talker and raconteur, a philosopher and theologian trained and trained well in De Propaganda Fidei, a Thomist, liberal and friendly in his attitudes, having a tolerance of persons and oddities, and an impatience of pretentiousness in fools. His dialectic has already discomfited a semi-pseudo-pyschologist of some complacency here, Dr. Palmer. He and I will get along well and he is keen to get an understanding of me without forcing me to suspiciousness. He is passionately interested in music and we are to read Italian and German together. He claims to see in me what he was formerly as an ardent communist before he abandoned materialism. But he forgets that I have no ardour, am mystic without faith, interested in theories for the persons and style of their expounders, fundamentally unreligious, and a proteus of opinion.

13 pyschologist] psycholgist $\mathbf{1 3}$ complacency] compacency

1 The Australians ... before Tobruk] The first major Australian battle of the war. From the third to the fifth, the outnumbered 6 Australian Division attacked the Italian garrison at Bardia on the Libyan border, capturing it with minimal casualties. Tobruk would fall to them on the $22^{\text {nd }}$, but their success made German intervention almost inevitable.

8 a Catholic padre] Edward Archibald 'Ted' Forsman (1909-1976) A Roman Catholic chaplain, 'a fluent though feckless linguist and possessed of a fine tenor voice ${ }^{\text {'168 }}$ who 'drinks and swears like a trooper, spent most of his life on the Continent, including ten years in Italy, is a talented musician and historian, and can discuss any intellectual topic without feeling conversion obligatory. ${ }^{369}$ Davin implies that this is his first encounter with Forsman. However, Forsman's brother describes Davin as adjudicating a debate Forsman participated in at Aldershot. ${ }^{170}$ Much later, Davin also referred to having met Forsman in 'summer and autumn 1940 when our brigade was stationed in Kent', ${ }^{\prime 11}$ Bassett, on the other hand, writes only at Christmas that 'We have been joined by a Roman Catholic padre, Forsman, whom we liked at Burnham. ${ }^{172}$ 8 Morkane] Cecil John Morkane (1881-1941) The rector of Holy Cross College, the Catholic seminary at Mosgiel. He was one of the referees for Davin's second Rhodes application. ${ }^{173}$ 9 AUC] Auckland University College. 11 De Propaganda Fidei] Sacra Congregatio de Propaganda Fide; possibly shorthand for the training college for missionaries run by this congregration, which produced many New Zealand priests. Alternatively, Davin is saying he is well trained in propagandizing the faith. 11 a Thomist ] Influenced by Thomas Aquinas. 14 Dr. Palmer ] Geoffrey Blake Palmer (1909-1980) A medical officer in command of the Field Ambulance detachment aboard the Athlone Castle. In civilian life he was a psychologist in Auckland. In later life, he was known as Geoffrey Blake-Palmer, under which name he was responsible for the cancellation of Janet Frame's lobotomy. 'He was barmier than his patients. ${ }^{174}$ 
I had great hopes of the work I should do on the ship but I foresee I shall spend my leisure in talking, playing chess with an excellent Maori player - Mackay - drinking and reading.

Today I read Louis Golding's Jewish problem: sensible, often naive, not profound but a book with nearly all of which I agree. And I have found some Shakespeare, some Browning and some Swift. If only we had no troops to train. Oh, for my leisure again.

So little done: and after the ebb of each day's tide the dull sediment hardens on the arteries of my soul, destroying suppleness. Resolution dwindles and the hope that shifts its longing till tomorrow kills the younger hope which should have squalled to life from today's travail.

Forsman's doctrine:

Absolute [evil] is the absence of perfection: in body i.e. physical evil e.g. absence of an arm (this could be the result of moral evil).

Moral evil presupposes conjunction of will and understanding: each being is so constituted as to will its own perfection. When it so acts as to infringe that perfection whether in itself or in another it is acting evilly: and since moral evil presupposes understanding the act to be evil must be done with an understanding of its implications. And every act is moral: even the picking up of a pin may be a right act in so far as it is permissible to pick up the pin. There are no morally indifferent acts. The rights of others are concerned with the development of their due natural perfection. Evil then is negative, it is concerned with lack, absence, negation. It is not an esse but a mode of esse. Satan in so far as he exists is good; but is in the manner of his existing bad.

Arguments for the existence of God.

[3]

\section{Jan contd.}

Ex motu. Everything changes: change presupposes a cause: this leads to the prime cause, or first mover. (If we argue that it is necessary for finite beings to argue in terms of finite concepts such as cause, beginning, end, proof, but these may not be transcendentally necessary: the fact remains one must so argue and if we wish to be reasonable must abide by reason's limitations. We cannot destroy reason logically without destroying the process by which we arrived at its destruction and thus find ourselves in a contradiction.) The first mover is God.

$6 \mathrm{my}$ ] $\mathrm{mt} 9$ tomorrow kills ] tomorrowkills 15 perfection] pwefection 27 argue that] argue=that 1 14th ] 14 th

2 Mackay] Wattie Horton McKay (1907-1941) An officer from Hastings in the Maori Battalion 'who turned in schoolteaching for journalism and has toured the world. ${ }^{175} \mathrm{He}$ was wounded with his section charging a machine gun at Maleme and died while a prisoner-of-war. 4 Louis Golding] Louis Golding (1895-1958) Manchester novelist from a Ukrainian Jewish family. His The Jewish Problem was a non-fiction examination of anti-Semitism for a popular audience.

11 Forsman's doctrine] This doctrine was presumably set out when Forsman, Davin and Bassett 'talked solidly for three hours, working up the scale from beer to Jews. ${ }^{, 176}$ 


\section{Tuesday 14th Jan.}

On Sunday found ourselves off N. Ireland - Bangor. Should have liked to get ashore and see Arthur Pyper or Roger Lloyd but there was no chance of it.

On Monday, yesterday, news came of the death of James Joyce. I wish I had a copy 5 of the Portrait with me.

Have been very low last few days with a constant headache and a cold. Spent much time in chess, reading Swift (I didn't enjoy Gulliver's Travels as much as I did when Swift-saturated), arguing and talking Italian with the Padre. But latterly we have been feeling too ill with colds to indulge in full-dress arguments.

Training threatens to be very boring what with route-marching like a blind mule in a treadmill, and tedious lectures by inexperienced lecturers, rehearsing stale and not even when fresh, interesting topics. The weather continues cold and I write this overcoated in my cabin. We are still in very dangerous waters far to the North, with blackout till 10 a.m. and now confined to our cabins because of an air-raid.

The YMCA man has provided me with an almost complete set of Shakespeare in Penguin series (Forsman's theory that $\mathrm{S}$. is the latest flower of the Middle Ages rather than the first of the Renaissance.)

My ear for Italian progresses rapidly, though my tongue still waits on the academic deliberation of my brain.

\section{Thursday 16th Jan.}

Existence settling down into a routine. This morning woke to bright sunny weather, perceptibly warmer. Left off pullover. Normal morning's boat drill, PT, short route march, this afternoon route march.

Am now waiting to begin my Italian lesson with the Padre. My ear is improving fast but my tongue still halts.

Last night being much recovered from my cold drank and played chess and listened to Forsman discoursing on Michael Angelo at Rome.

It is splendid to stand on the deck watching the sea go by with the very pace of time and the horizons that change and do not change. We see no seabirds now and I miss the sight of them, their flying is the nearest thing to perfection.

Last night a short hot argument with Orbell as I climbed into bed.

[Oxford 26 March]

\section{Jan contd}

\footnotetext{
3 Lloyd ] Llloyd

22 PT ] Physical training. 31 Orbell ] Richard Mitchell Scott 'Dick' Orbell (1915-1986) The adjutant of 23 Battalion,
}

a shipping clerk from Oamaru. 31 as I climbed into bed. ] Davin and Orbell were sharing a cabin. ${ }^{177}$ 
NZ politics. 'Lee disgraced himself with his two books.'

These among the few attempts ever made in NZ at honest writing. How it takes a literary judgment to bring out philistinism. I feel an angry contempt for these men who never pay any attention to politics until their income is being straitened, their moneybags threatened. And even then they would be less intolerable if their interest were at least informed. And Ian Milner? In Oxford he got a first, in America he was well thought of, in NZ he is his 'poor father's crackbrained son'. So much «for» their respect for an expert. I do not think I can ever live again in such a country. This battalion brings back too vividly its snobbery, its provincialism, complacency, stupidity, prejudice, partiality, ignorant positivism, and its utilitarian materialism of the crassest, most ingenuous, brazen kind. To such people one put one's very soul into argument and they will say 'he's got the gift of the gab'. If they catch a glimmer of misunderstanding 'he's a red'. And that at once labels, explains, and refutes. I talk gibberish because I use the King's English. To employ a vocabulary of more than three hundred words is to forfeit attention and invite the reputation of a madman.

\section{Sunday 26th Jan.}

We reached Freetown late yesterday morning and are lying at anchor here for a few days. A great mass of shipping all about us and that speaks much for the volume of British shipping. It is extremely hot though I've known it hotter in more temperate latitudes. I am sitting in the 1st class lounge writing up this diary before moving on up to the boatdeck for a sunbathe.

Most of my leisure in the last twenty-four hours has been spent watching the natives in their canoes trying to sell fruit or beg from the soldiers. Their bodies are beautiful to watch, of a vital chocolate colour, muscular and very graceful. They manage their little canoes with extraordinary skill.

1 'Lee disgraced himself with his two books.' ] 'Lee disgraced himself with his two books." 4 any ] ny

1 Lee disgraced himself with his two books ] By 1941, John A. Lee had published three books, not two: Children of the Poor (1934), The Hunted (1936) and Civilian Into Soldier (1937). All were semi-autobiographical. The reference is probably therefore to the first two, which describe Lee's bitterly poor childhood and attempts to escape Borstal.

1 Lee ] John Alfred Alexander Lee (1891-1982)

6 Ian Milner] Ian Frank George Milner (1911-1991) A New Zealand Rhodes scholar. He opposed New Zealand's entry into the war and moved to Australia. While in government service there after the war, he was suspected of working as a Soviet spy. He moved to Prague, where he had a succesful academic career. 7 poor father] Frank Milner (1875-1944) Ian Milner's father was the rector of Waitaki Boys' High School, where he became influential in New Zealand education. His educational ideals, centred around the development of citizenship, depended upon the promotion of imperialism and patriotism. His influence on Davin's generation as they reacted against this is thoroughly discussed in James McNeish's Dance of the Peacocks.

18 A great mass of shipping] Geoffrey Cox, with a journalist's eye, counted seventy-nine. ${ }^{178}$ 


\section{Wed 29th.}

Was interrupted by Cunningham who always goes on the booze in port and the waterwagon at sea.

Have just come down from the boatdeck where I have been watching the coast 5 slide by as we leave Freetown. We are now out beyond the boom and ready for the open sea. Behind the great piled clouds loom over the world. And in a steady line to port and rear the greatest liners of the world move down to Capetown.

The weather has been so warm that shorts and shirt have been constantly soaked but now we shall have the breezes of the sea. I shall regret Sierra Leone little: all it had to give were the beautiful bodies of the negroes in their canoes and these were melancholy since they contrasted so much with their humilities, and the native boats with their sails, their bright fruits and the many-coloured garments of those within them. But everywhere the big stranger ships dominated. Yet the little canoes so close still to the first conquest of the water stirred my admiration more. The whole convoy was implied in one of these.

The padre told me a story. An Irishman he knew lost a brother to the Black and Tans. He took his brother's son to NZ to keep him from these troubles. They worked together tunnelling. Then the war came: the nephew was a grown man. He went to Gisborne, got drunk and enlisted. His uncle was broken-hearted, went on the booze and became an embittered wanderer.

Life goes on as before: chess, beer, talk. But I think I am becoming a little stale at last.

Thurs. 3oth Jan.

Men are all out on the deck airing their clothes, mending and washing.

\section{Thurs. 30 Jan contd.}

Looks like Petticoat Lane combined with an oriental bazaar. Have just finished preparing a lecture on the pistol for tomorrow. Must now rearrange my Italian hour because of PT and go visit my batman who is crook it appears. Birthday of Ensor and Jones yesterday but managed to avoid getting tight. A man tends to age more on his birthday than in the whole of the remaining year.

3 waterwagon] waterwaggon 7 of] f 8 have] hve 15 implied] impied 18 tunnelling] tunneling

16-20 An Irishman... an embittered wanderer] This provided Tom O'Dwyer's backstory in For the Rest of Our Lives (although the murder was not done by the Black and Tans). ${ }^{179}$

16-17 the Black and Tans ] Temporary constables recruited, mainly from Britain, during the Irish war of independence, infamous for their brutality and attacks on non-military targets.

27 Petticoat Lane ] A street market selling clothing in the London East End. 
Have been snared into leading a debate next week. Have never debated since leaving Otago and did it then only for purpose; but similar purpose exists now so I suppose I must do it, in spite of my contempt. Have a lecture on life at Oxford brewing too. The lecture will have to be a little less many-sided than the life since Oxford is as much parti-coloured as Plato's democracy. Am rapidly becoming almost illiterate.

\section{Feb. 3 Monday.}

Now nearing Cape Town and due in on Saturday. Looking forward a bit to a stretch. May look up Meiklejohn. But lot of work intervening between now and then: have to lecture to B Company on Life at Oxford. God save the mark. Must lead a debate on Wednesday night. Have to collaborate with Fyfe and Bassett on a preposterous 1000 word article for the Patriotic Council on the Battalion's life in England and have to prepare lectures on consolidation and intelligence. The latter an interesting development. The obvious man to do the job is the I.O. But the colonel, foreseeing perhaps that I may have to be pushed forward and he'd better go forward first or else preparing a substitute whom he imagines he can handle more easily has seen fit to thrust it on me. I feel by divers faint signs that my day is just beginning to peep. I've waited a long time and perhaps even now am wrong. Il nostro colonello is a man of almost feminine mobility: he is also one of those men who find it almost impossible to leave a group without making a joke to wreathe all faces in smiles. Though the jokes may lack something in wit, constant practice may wear away the stony face of Humour herself and what the jokes lack in complaisance exalted rank supplies. He is as formidably illogical as a woman too: using the rational only as an instrument to justify the sinuosities of a mind essentially irrational.

Forsman bitterly offended with Hawksworth: the latter with sanctimonious impertinence suggested he drank too much. Hawksworth at loggerheads with his men and with his P.C. - Palmer! Forsman also embroiled against Dittmer, who seems bent on preserving his record as a discourteous curmudgeon.

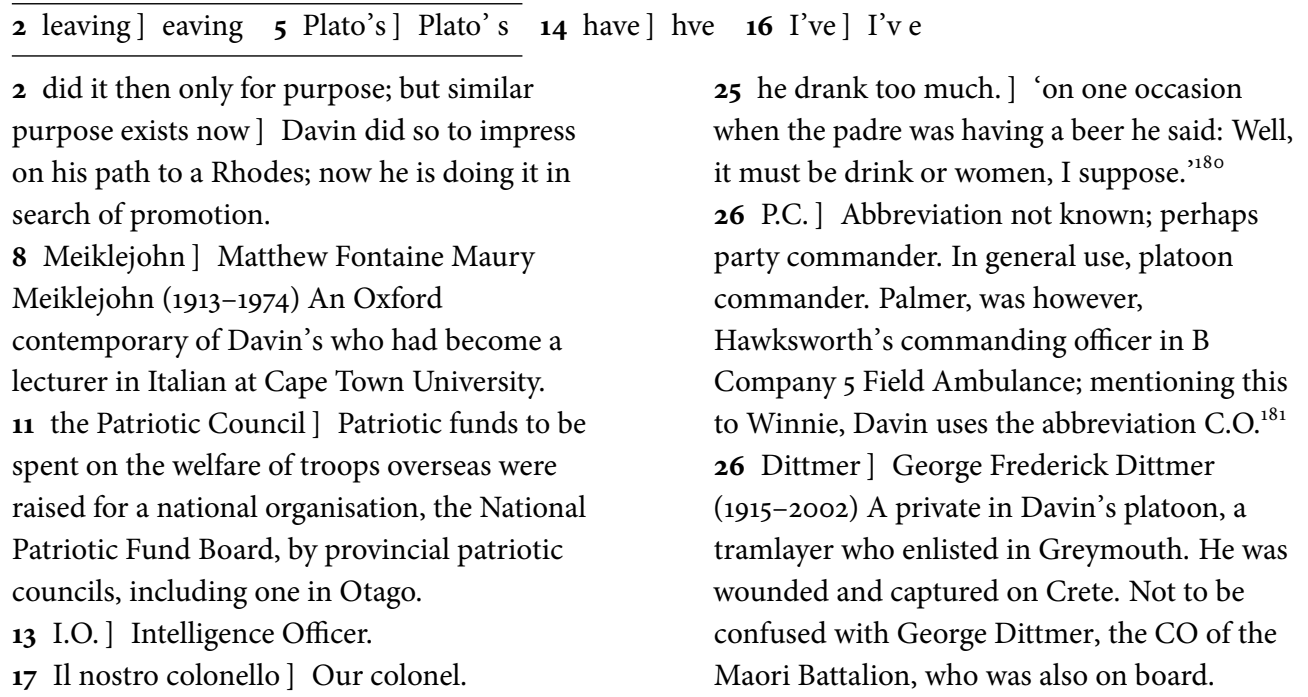


Mackay has been refused all shore leave for the duration for opening his porthole during blackout.

\section{Thursday Feb 6.}

Pressure still not letting up: must finish letter to Winnie for tomorrow's post, write part of an article for Patriotic Council, must prepare lectures and consider plans for ship's magazine which I have consented to undertake. Last night had the famous debate which, oddly enough, was a great popular success. Had done nothing about it in the morning but hit upon the idea of a company conference, got all their ideas, shared them out among the team and thus managed to win the debate. As the colonel was judge it was an excellent opportunity and for once I was able to excel myself. Rather to my surprise he summed up pretty effectively, though I imagine I'm a trifle biased by his giving me little short of the maximum. Romans also spoke very effectively.

Today has been fiddled away in the usual fashion with the exceptional irritation of an hour and a half's wait for an inspection.

\section{Friday Feb 7.}

Just finished letter to Winnie. Last night the Maoris celebrated the Treaty of Waitangi: an English triumph to make them celebrate their own swindling. One of the best hakas I ever heard, much beautiful singing. Here in the lounge this morning the treaty is being recovered from.

\section{Thursday Feb 13.}

Arrived Capetown Saturday, left yesterday morning. Leave from Saturday after lunch: went to a few pubs. By 6 p.m. began to feel drunk but recovered and retained subsequently the audacity of inebriation with the coolness of sobriety. Had an entertaining argument in Cape Town Club with the local philosopher. Obviously he had never previously been contradicted. His friends and victims gathered about in delight at the performance. Seizing an appropriate moment when I was on top we departed. King and I were then picked up and taken to dinner by two women at the home of one of them. Husband turned up and I had a good argument with him but about what I

$\mathbf{1 3}$ away] wway $\mathbf{2 2}$ yesterday] testerday

12 Romans] Reginald Everans [Everard] 'Reg' Romans (1909-1943) An officer in B Company. From Arrowtown, where he managed a butchery. He was quickly shifted from the battalion to be trained for higher command, became a company commander in the desert, and then was made commander of the battalion, after a brief interlude, when Leckie departed. He was killed in Italy. 19-20 the treaty is being recovered from ] Bassett: 'a welter of mutton birds and ale. ${ }^{182}$ 25 Cape Town Club] A private club in Queen Victoria Street. ${ }^{183}$ 
forget. Thence to Kelvin Grove Club: full of boiled shirts and officers, the sort of show you could see anywhere in the world. Britain's contribution to civilization. We left almost immediately. The pubs being shut we asked some women where we could get a drink: they took us to the Ritz Hotel, Sea Point, where they lived and we got drinks long after hours. One of the women was very intelligent, about forty-five, divorced two months before, very cynical and unhappy. One was of Dutch-French extraction, thirty-three, very pro-British, married ten years to a wireless observer in the SAAF. A happy life had ceased to be happy two months ago when he fell in love elsewhere. She was still in love and correspondingly miserable. The third was a Jewess much younger, married also, her husband in the army. She was still in love with him but despised him for telling lies about money and about his women. Most of this it took us a few days to find out. King fell for the jewess and the two had an affair ending for that night in a quarrel.

We took a taxi home and were overcharged. I refused to pay and insisted on seeing the police. The driver consented, thinking he would tell his story in Afrikaans. By listening closely I could understand the conversation from German. So I contradicted him in German. In the ensuing argument I told them that there was little difference between Afrikaans and German, showed that the policemen were fools and the driver a scoundrel and added that I disliked policemen anyway. In the end they gave up in despair and suggested we pay what we thought fair. Which we did and were still swindled.

On the Sunday Rex was on picquet duty. I went back to the Ritz and dined there, meeting among others a drunken remittance man and the Dutch girl's husband. An interesting case: v. conceited and egotistic, intelligent and able. He was full of a story that he was indifferent to life, had nothing more to make him care whether he lived or not. This was obviously very painful to his wife: but she was not clever enough to listen sympathetically and interrupted him by begging him not to be so 'morbid'. This of course only whetted his sadism. It was plain that he would have liked her to have an affair with someone to ease his own conscience, though I suspect it would have roused his jealousy. He was also Dutch, with a strong masculine, spoiled personality.

R. turned up somewhat plastered with a gorilla but merely made matters worse for that night.

22 and dined ] anddined

1 Kelvin Grove Club ] 'The Kelvin Grove Club is a country club some 5 or 6 miles from the centre of Cape Town' in the suburb of Newlands, below Table Mountain. ${ }^{184}$ 1 boiled shirts and officers] Stiff dress shirts. In contrast, Brian Bassett, inside the club, thought that 'by far the greater proportion of visitors were the cunning N.Z.E.F. which had again taken possession.' He did note 'C.O. Leckie at a nearby table, full of cheer and with a rather nice partner from the Auxiliary Transport Company. ${ }^{\text {, } 85}$

7 SAAF] South African Air Force. 22 picquet duty] Heading a small detatchment of troops to keep order. 23 remittance man ] An emigrant living abroad funded by remittances of family money, normally because considered undesirable at home. Compare Davin's later novel No Remittance. 
By this time I was pretty interested in the place: it seemed to be full of discontents and jealousies: the women nearly all married and grass widows, the men much fewer and all in some form failures. Except a little Norwegian captain whose ship had been torpedoed and who was waiting for another one. He was fretting

\section{Feb contd.}

to get back to the sea and in the meantime drinking and kicking his heels. A charming and intelligent man with great force of character. He told us the story of the religious sea-captain who tried to force him to attend religious service.

On Monday R and I want to the Queen's further out but not liking it much came back to the Ritz. Here we found Rita the jewess had forgiven R so all was smooth again. We dined there and spent the evening as before drinking and talking and ending with a walk over the beach.

On Tuesday I was pretty done from drinking and the exhaustion of vitality poured out in furious talking. But in the afternoon was too weak to say no to a sight-seeing tour, in cars lent by the Mayor. Manson got a party up, among them Gordon C. The idiotic day was redeemed by a couple of incidents. It was explained that one of the cars had belonged to George V. In the excitement of arranging that he should be with the senior officers Manson forgot this. But G. who had been allotted to M's party and did not like that crept in one door and out the other. Being observed he claimed the car was too crowded. This gave $M$ his cue and ostensibly for more room he transferred his party to George's car. G sneaked back to ours but that no longer mattered since $M$ would be able to write in his diary that night that he had ridden in King George's car. At tea we discovered that almost the entire conversation among the others had 5 been the virtues of Invercargill. (And I personally think I noticed that Falconer has a hostility for me) [// Not surprised and don't blame him: DMD March 1979. What a bloody prig I was. //] Our conversation as far as G and I were concerned was chiefly sleep. Embarrassing moment: I dreamt I was riding beside a beautiful park. I asked what park it was, awoke at the sound of my own voice and found to my horror that the girl next to me was gazing at me with the sympathetic attention reserved for madmen. There was no sign of anything but dreary stony waste.

The cars of course had a minor breakdown and we were belated: but the country was beautiful in parts and interesting. In other company it would have been an enjoyable day. Note: the embarrassment of people when confronted with a splendid view: if fools they try to say something appropriate, if not they are concerned at the inadequacy of words.

Monday evening was spent as before at the Ritz, drinking heavily and talking much.

23 ridden ] r idden 24 almost ] alomost 33 would ] wou d 33 enjoyable ] enjoya ble 35 concerned at] concernat 37 Monday evening] Mondayevening

2 grass widows] Women whose husbands are

11 Rita ] Not identified.

away; in this case, at war. 
Every morning so far we had had a route march: excellent propaganda that long column of New Zealanders marching through the suburbs of Cape Town. But the unspeakable torment of those mornings and the hangover that accompanied them.

Tuesday morning I escaped the route march by getting permission for Mackay and myself to go and buy paper for the ship's mag. I was confused and incompetent but Mackay handled everything with great efficiency. By afternoon we were at sea and the ship was silent with every man asleep in his bunk recovering from the second battle of Capetown. Even now their eyes have a faraway look and their voices seem to come from a great distance.

The battalion has lost 20 men and the colonel is not unnaturally furious since in other respects the trip owing to the high standard of misbehaviour set last time was very orderly. Capetown is the most interesting place I have seen for a long time: the atmosphere is full of tensions and stress. There is antipathy everywhere. Germans hate British, British hate Germans and dislike Dutch, Dutch hate English and all hate the natives with the fervour of potential fear. And the Jews enjoy a common disfavour. The place is full of dynamite, bound to see trouble unless the various conflicts are somehow resolved. A true legacy of

[8]

\section{Feb contd.}

past evils. And yet it is in a way remote from this war, preoccupied with its domestic 20 hostilities.

The first city I have seen lit at night since 1939.

Among the pro-British Smuts is revered almost as a god. He is the local Churchill and must have real genius.

A private of ours told a Colonel to 'hop his frame out of here' when the Colonel refused to give up the private's chair in a pub.

10 The battalion has lost 20 men ] Ross has only thirteen men left behind, and says that the explanation was that 'for security reasons, no sailing date had been announced. Most of the absentees would have been on board had they known when the convoy was departing from Capetown. ${ }^{186}$ This is perhaps wishful thinking. Leckie's 'Voyage Report' states that 'I regret to report that seventeen men of this unit were left behind in Cape Town. Of these, 15 are definitely absent without leave, and no excuses whatever can be offered to justify their absence. Two men, both of excellent character and thoroughly intelligent and reliable, were members of a specially selected picquet detailed to go ashore and search for absentees on the morning of Feb. 12 (date of our departure from Capetown). I am conviced that these two men missed the convoy through having to carry out their duty. ${ }^{, 187}$ 11-12 the high standard of misbehaviour set last time was very orderly] On the way out from New Zealand to England the Cape Town chief of police told Hargest afterwards: 'we have loved having both you and the Australians, but, pray God, you never both come back together again. ${ }^{188}$ This time round 'our fellows [...] behaved wonderfully well, especially in contrast with the Aussies who were here with us before and are not allowed in now. ${ }^{189}$

14 Dutch ] i.e. Boers.

23 Smuts ] Jan Smuts (1870-1950); at that time the South African Prime Minister. Like Churchill he had replaced a Prime Minister associated with appeasement.
5 
W.W. did not come abroad because of a sore jaw. But he is done for in his battalion, I hear, because they suspect his bona fides. He probably intends to transfer to the British. Cherchez la femme. Turton also. Geoff Cox is with the 21st.

My man Walker was refused leave because of medical grounds i.e. they suspect 5 he is cracked. He bluffed his way ashore and has not come back. But he has a good case: if responsible for his actions he should have been let ashore; if not, he cannot be punished.

\section{Monday 24th Feb.}

A little more than a week and the voyage will be over. Stories current of a raid somewhere in our wake but time enough to get troubled about that when we hear shots across our bows.

Charming incident yesterday: sentry one of whose duties is to prevent people interfering with overboard alarm tried to open bottle of mineral water on it. Broke glass. Bells rang on bridge, lifebuoy and signal lamp shot overboard, general pandemonium.

Still take a sporadic interest in the news but the wireless is so cacophonous and inadequate that it really makes few inroads on our illusion of isolation. And the ship like time itself goes always on.

Rather homesick for these latter days. First time in my life, I think. Usually carry my own solipsistic world with me. But missing Winnie and Anna greatly. They have become a sort of symbol of peace to me. Not only the cessation of war but perhaps of the restless twisting and writhing dissatisfactions with which I make my life more miserable than it need be.

Life on the ship has become a bit dull. Beer and argument for the evening are the routine and as usual having once discovered the technique and hobbyhorse of my chief talkers my interest wanes into monotonous friendship. If only I had the vitality for enthusiasm.

Things looking fairly hopeful for my military career. My patience and careful building may justify themselves yet. [// !!! ///] I wonder how Winnie and Anna are standing up to the winter and their loneliness. I bet Anna sleeps on Winnie's bed every night. Thank God she has Anna. I don't know what I would do if I lost faith in her.

6 responsible] resposinsible 27 fairly ] fairl y

3 Cherchez la femme ] 'Look for the woman' (to explain his behaviour)

3 Turton ] Not identified. There was no officer named Turton in the New Zealand Division. However, Edmund Christopher Turton (1915-1983) was both at Balliol with Davin and St Bartholomew's with Geoffrey Flavell. Possibly some vagary of his behaviour is being alluded to.

3 Geoff Cox is with the 21st. ] Actually, the

29 loneliness ] lo neliness

29th, which shared a ship, the Duchess of Bedford, with the 21st Battalion. 4 Walker] Jack George Walker (?1907-1973) A private in Davin's platoon, in civilian life a deer-hunter. 27 Things looking fairly hopeful for my military career. ] Forsman had reported a conversation in which Leckie 'said he was going to put my name up for Intelligence. ${ }^{190}$ 
Things still in a state of brooding menace in the Balkans. I think we may be fighting Germans in Greece or Turkey. A strenuous week ahead writing and editing the ship's magazine. But I suppose it will get done as the impossible usually does.

I wonder if I shall ever write again. Even if it doesn't kill me this war may send me home an anarchy of despairs.

The Maoris are route-marching round the decks, singing strongly, the sounds like their shadows coming jerkily through the windows of the lounge.

Have just received a book The Story of the Lake by Negley Farson, not at all bad, in the idiom of all the social rebels who cannot find a political faith.

Enough for today. I have been writing for an hour. Unprecedented effort!

\section{Friday 6th[(?)] March.}

Writing in tent at Helwan. Am sitting up in bed, having finally yielded to the assault of a cold caught a week ago on the ship and now developed to flu.

We arrived at Tewfik on Tuesday and entrained for Helwan. Long tedious train journey made additionally dull by the abundance of hangovers. Saw a delightful little boy at one of the stations cadging cigarettes with a wealth of assurance, humour and drama. Desert looks very much as expected: gradations in colour tones very subtle and pleasing.

Last week on ship rather a nuisance because of work on magazine. But finally concluded on last morning and now await publication.

Previous echelon left morning of our arrival: others went off yesterday. Camp very big and on the whole very good. Pyramids visible in the distance. More attractive from here, I imagine, than closer where the post-card tourist element probably predominates.

2 week] we k 7 their ] thei $r$

2-3 A strenuous week ahead writing and editing the ship's magazine] Davin's collaborator in this venture, writing in the heat of the moment, was more explicit: 'Davin and I are running the ship's magazine which occupies our time fully. Our constant pressure on all units and personal exhortations of individuals produced a mass of material, perusal of which makes the soul writhe. Scores of tomes entitled 'My Impressions of England', each one almost identical in its bathos and banal accounts of boring incidents already published months ago. We have rewritten the less repulsive poems and prose and rounded up a few sketches. The Maoris astounded us with the lyrical colour of their descriptions of nothing [...] I still hope to pad it up into something better.' ${ }^{\text {191 }}$

8 Negley Farson] James Negley Farson (1890-1960) American foreign correspondent.
The Story of a Lake was his first novel, a semi-autobiographical narrative of an alcoholic journalist who retreats to British Columbia and dies.

10 I have been writing for an hour.] Probably not on an early story of his own. Bassett's discussion of the magazine continues later: 'The magazine still demands close attention. Not one of the articles has come in fit for publication without being almost completely rewritten, and Davin and I have had to scribble a lot of stuff ourselves, a repulsive task as we have to constantly revise our own matter to suit the troops who form our public. ${ }^{, 192}$

17 gradations ] Insensible passsings from one to the other; probably picked up by Davin because of the use of the same word in its military sense to describe the order of seniority even among officers of the same rank. 
Looks as if our stay will be brief: so can't expect to see much of Cairo. Most of our predecessors seem to have found it dull. But if I can dig up Munir should be able to get better inside look. First night of leave tonight I have lost through the flu but feel too low-spirited to care much.

Many changes in battalion: Tom Morten off to hospital with crook kidneys - an honest, modest, able soldier. Am not likely to see a better man over me. The awful threat of Manson now removed: Maj. Thomason is coming back. For this relief much thanks. Falconer back and Leckie goes down to 2 i.c. Am not altogether pleased at this; have not been able to size up Falconer but distrust his judgment of men and his Hawksworth smile. Freyberg in great form: seems to me an ambitious, able, ruthless, dangerous man. Has the men very impressed because of his anxiety to keep us functioning as a single unit: but to me it seems his object is to have his name easily singled out as an independent commander. [//Inept and unjust. DMD, 1979//]

Brian Bassett down a pip: but his ability will bring him up again. Many changes and rumours of change: Tom Pugh and Reg Romans off to Training Battalion. No news of myself and I have a hunch that under Falconer my designs will not prosper. I have no luck with these people so far. But my day will come.

Day's work mostly desert route-marching - not very hard.

Big drunk among the men the night before last, celebrating meeting of friends etc. Miserable looks on the route march next morning.

Rex busily plotting his Cairo nights but difficult without recce. He will find it a hard nut to crack.

Today or tonight must write home or to Winnie. Tomorrow cables and a parcel of butter for Winnie. No letter from her. I knew one couldn't get here but was disappointed just the same. We have so much in common besides love. One letter from home. All well but mother ageing. Must write.

We have a fine big tent. And I think when I recover I shall like it here. Sandy «,» Rex and I get on pretty well. The climate suits me and I would like to save money and

7 removed:] removed $\mathbf{1 3} \mathrm{DMD}, 1979] \mathrm{DMD}, 1979$

2 Munir] Ahmed Munir (Mounir) Hassan

Sabry (1920-?) An Egyptian friend of Davin's; he had met him at Balliol.

10 Freyberg ] Bernard Cyril 'Tiny' Freyberg (1889-1963) The commander of the New Zealand Division.

11-12 his anxiety to keep us functioning as a single unit ] Freyberg insisted upon keeping his division as a unified whole rather than allowing it to be split up to suit transient purposes. 193 'His insistence on keeping the Division intact and not allowing it to be employed piecemeal was no doubt right from New Zealand's point of view, but it nearly drove poor Archie Wavell, Arthur Smith etc.
18 desert] de sert 26 ageing ] aging

round the bend.' ${ }^{\text {'94 }}$

14 down a pip ] Ranks below captain were indicated on shoulder boards by the number of stars (pips) worn. Basset noted 'I expect in the reshuffle when we join the others Colonel Falconer, will come back, in which case the C.O., Major Kelly, Orbell and I will go down a pip. Then of course, my captain's moustache will have to go too!'195 Falconer returned to the battalion on the $5 \mathrm{March}^{196}$ and those moved up in his absence reverted to their former rank, removing a pip.

15 Tom Pugh ] Thomas Jacob Graham 'Tom' Pugh (1904-1986) The commander of D Company, a farmer from Mosgiel. 
grow hard. But I fear we shall be here only a short time. If only my job were more complicated and interesting.

Was in Maadi the other day for clothing. Enjoyed the trip, the colour and the Nile. But there were some sadly squalid spots. Streets that were great mud pools after the recent rains: and then the contrast with the comfortable spacious middle-class district. The poor get even more kicks here.

Cunningham; 'Scenes we haven't seen since we left Sunday School.' All these men

[10] one sees could easily be cast as apostles | and inspire the correct quantum of pharisaic distrust.

\section{Thursday 13th March.}

Have been in Cairo several times now. Contacted Munir last Saturday and spent the evening with him at the Egyptian Officer's Club and the Continental. Munir looking very fit and in great form. Somewhat toned down: presumably has to postpone revolt against Mother's domination until she recovers from mourning. Met Geoff Cox also: now at base details but still looking as if living on nerves.

Another night called on Munir and went on to Lule Abdul Huda's. Was somewhat tight but seemed to amuse them immensely. Sort of symbol of Oxford for her, I suppose, as for Munir. Both homesick for that freer life. Amusing to see how carefully Lule was spared being alone in the same room with a man. Munir and Lule both very keen for Winnie to come to Egypt. Would love it but seems too good to be hoped and the seas are so dangerous. I doubt if I could take her being at sea with the same courage that she took mine; or seemed to.

\section{Tuesday 18th March.}

\footnotetext{
13 fit ] fir

12 Egyptian Officer's Club] Munir was a second lieutenant in the Egyptian artillery, thought Davin. ${ }^{197}$ The Balliol College Register suggests he was in the cavalry. ${ }^{198}$

13-14 has to postpone revolt against Mother's domination until she recovers from mourning. ] Sabry's father was Hasan Sabry, the Prime Minister. He died in Parliament on 14 November $1940 .{ }^{199}$

16 Lule Abdul Huda ] Velia 'Lulie' Abu'l Huda (1916-2012) The first Muslim woman to study at Oxford, where Davin met her. She was born and lived in Cairo, but - an Oxford contemporary remembered - was a daughter 'of the hereditary prime minister of Jordan and
}

descended from the Prophet. ${ }^{200}$ She worked, at this time, with Freya Stark for the Ministry of Information. They ran an organisation called the Brotherhood of Freedom, which was intended to persuade Egyptians that they and the British shared common goals and would share the benefits of success. The method was a combination of speechifying and At Homes. Reggie Smith wrote a song about the results: 'We don't want to sit in the coffee bars / Lounging in the cinemas / Looking at the movie stars / We just want to ROOT for demo-cra-cee / We are Miss Stark's Wee Free. ${ }^{201}$ 
Wrote home and to Winnie last week. Letters from Winnie on Sunday, enclosing letters from Tom and Philip Barton. Winnie seems well and fairly happy. Anna teething. Great relief to hear from her, though it made me a little sad with its reminders just at a time when we were preparing to depart.

Had great business as O.O. night the Div. Cav. went out. Tried to burn down the canteen and I was up till two in the morning watching them. Astonishing how badly these New Zealanders hold beer.

One of Rex's nights deserves a note. Made friends with a lot of Egyptians in Cafe Liberte and persuaded them to take him in search of a girl. Only special houses are allowed to take NZ soldiers and this was not one of them. He was disguised with a tarbush and Egyptian coat, the idea of disguising him as a girl being rejected. Outside the brothel gates stood a policeman who always has to be bribed by entrants and bawd to go away - a lucrative position. The girl was terrified when she found she was dealing with a NZer - memories of the last war. Finally one of the entourage had to be brought in. He stood with his back to the proceedings but watched in a mirror.

On Saturday afternoon went into Cairo but all the banks were shut and so could not send away any money. In the evening called on Munir but he was out. After great difficulty found Lule's and stayed to dinner. It appears that the Abdul Hudas are in mourning for an ancient aunt who died recently. So the girls are not allowed out except to work, may not play music and may not drink - which they couldn't do in any case. While there I became terribly tired and set off for home. Stopped at the Continental and had a few pernods by myself. Thence to the station. Took bus from Helouan but got so disgusted with the drunks on board and their bullying attempts to defraud the bus conductor that I got off and walked the rest of the way.

Sunday was spent packing, striking tents etc. and hanging about the camp. Fairly dreary day except for getting the letters from Winnie.

Yesterday afternoon we marched to Helouan and thence entrained for here. I was sorry to see the last of Helouan. There was something beautiful about its yellows and clay colours set against the desert hills.

\footnotetext{
2 Tom] Thomas Patrick 'Tom' Davin (1911-1991) Davin's older brother.

2 Philip Barton ] Philip Treherne Barton (1917-) Another Balliol contemporary, where he trained as a chemist; he joined the Burma Frontier Service, had a murky but distinguished war as a guerilla there, then became a civil servant in Nigeria. 5 O.O. night the Div. Cav. went out ] This became a story told in For the Rest of Our Lives: 'and a terrible bad night it was to be on guard what with all the boys still drinking to celebrate the Second Ech coming in from England and on top of that the battlion moving off to stage at Amarya and where next not hard to guess. And the whole lot of them thinking: well,
}

here's for a last good boozeroo. ${ }^{\text {,202 }}$

11 tarbush] The distinctive Egyptian hat, equivalent to a fez.

14 memories of the last war ] ANZAC soldiers in Egypt during the First World War were famously indisciplined, especially in the infamous riot known as the 'Battle of the Wazzir', which targeted prostitutes. ${ }^{203}$ Wavell's first address to the Australian soldiers arriving in the Middle East played strongly on Egyptians' 'lively apprehensions of what Australians might do in Cairo and elsewhere in Egypt.' 'I look to you,' he continued, 'to show them that their notions of Australians as rough, wild undisciplined people given to strong drink are incorrect. ${ }^{304}$ 
Alf Moodie was on the train. The brother of Nance. She is married now. His face and laugh bring her back like a ghost, meagrely.

The train journey was interesting while still light. Only it is infuriating to travel with people like these: one is jealous of the spontaneity of their reactions and dismayed because they are so unthinking. Their contempt for the 'Wog' is so much

\section{[Tuesday 18th March contd.]}

based on complete misunderstanding: not that I understand the 'wogs' but I can guess at the environment and conditions that abase them and I admire their merriness. Some of the children are remarkably beautiful but it is so 'red in tooth and claw' to see them tumbling each other in the dust for half a piastre. But they enjoy the diversion our passage affords them and I've no doubt that they think the soldiers even bigger fools and rogues than the soldiers think them.

The squalor of the outskirts of Cairo was the worst I've ever seen and yet in principle very little different from the Paddington approach to London, say, or the coming in from across the river. Such cities as Cairo and London are only superficially different; the principle lying behind the plague spore of each is the same essentially. But there is much that is handsome about Cairo and there is hope in its vivacity, life in its colour.

The Nile has disappointed many of our people: their criterion for rivers is size. But it is a graceful and delicate river sinuous and beautiful as the serpent Cleopatra must have been. And the feluccas have something of the forward-leaning beauty of the camel. I found a nostalgia for peace in the quiet little family groups working in the fields, though it is not hard to guess the ugliness lying behind. The trip here through the Nile region was for this scenery extraordinarily interesting: water buffaloes, goats sheep and allotment[(?)] crops, blended with the quiet greens and a magificent sunset.

Then the dark and the banality of a railway carriage and the usual load of officers. Finally sleep.

We got to the station about eleven and marched 2 miles through the dark to find our tents were occupied. The men had to sleep under the lee of a stone wall. We crowded

1 brother] broth er 5 the 'Wog'] the 'Wog' 7 [Tuesday 18th March contd.] ] [Sunday 18th March contd.] $\mathbf{8}$ based on ] basedon $\mathbf{1 2}$ passage affords] passage afford 21 feluccas] feuccas $\mathbf{2 1}$ forward-leaning beauty] forward-leaning3/4beauty $\mathbf{2 4}$ extraordinarily] extraordinari $y$

1 Alf Moodie ] Alfred Whiting 'Alf Moodie (1913-1941) A regular soldier from Dunedin who was C.S.M. of D Company. He was taken prisoner and died in Greece.

1 Nance] Nance Wilson Burnett (1911-2007) Apparently 'an old Dunedin flame.'205 10 'red in tooth and claw'] The quotation is from Tennyson's In Memoriam A.H.H. 14-16 The squalor... from across the river ] Davin adapted this observation in For the Rest of Our Lives: 'His mind flew back to the approaches to London or any great industrial city of the west. The same overcrowding and dirt and disease and squalor, the same pressure of poverty outwards from the rich centre like some horible ringworm. But here it was worse, the people ground down by colour as well as by class. $^{\text {'206 }}$

21 feluccas ] Wooden sailboats used on the Nile. 
six of us into a tatterdemalion tent. I had to wait up an hour for my kit in the bitter cold but was enlivened by rum.

This morning an inadequate breakfast, sunshine, desert and tents as far as the eye could see. In the foreground rubbish and dirt which we have now cleaned up. We shall

5 not be here long, perhaps go today where we don't know. I shall not be sorry to see the last of Amaria.

\section{Thurs 2oth March.}

Sitting up in bed in the tent. It is 7.15. I am being persecuted by a parcel of bastardy whom I won't immortalise by naming. One is fat (Canterbury lamb), the other is thin. Also four bottles of beer have just come over from the NAAFI canteen.

Route march this afternoon. Much concerned with a tendency I have to go into a sort of coma which seems to be a sort of walking sleep. I feel this coming because my heart seems to descend into my stomach and no matter how much I struggle (the struggle is the most difficult) I seem to lapse. The very intensity of effort seems to produce a sort of unconsciousness. It usually terminates by my legs giving way under me and I have to give a sort of spring-lamb skip to recover my footing and step.

\section{Friday 21st March.}

Woke up very depressed after a night of heavy sleep, during which my bed had slipped its moorings. Morning spent route-marching through a heavy sandstorm: route would have been interesting as we passed through several villages but the sand made observation practically impossible. It was the best thing in the circumstances however as I find such monotonous yet exacting exercise the best thing for gloom. Afternoon kit inspection to find extra battledress. As the men who had them were to be charged (although possession was not their fault) and as the BD would have been sent to moulder at the dump we arranged to have our harvest dropped under cover of night into a deep well.

\section{March contd.}

Anomalies of war!

All day we have been living in dusty squalor like pigs in a dry wallow. Tonight there is nothing to do, the beer at the canteen is sold out, my depression has returned

\footnotetext{
2 was enlivened] wasenlivened $\mathbf{5}$ where ] wehere $\mathbf{2 2}$ monotonous ] monoton us

4 rubbish and dirt which we have now cleaned up ] The battalion war diary notes: ' 3 rd Echelon moves on to embark for GREECE always a jump ahead. Our lines hastily vacated

by RMT [Reserve Mechanical Transport] in fairly bad state. ${ }^{207}$

11 Route march this afternoon.] The march was 'into the desert and back along railway. ${ }^{208}$
} 
at its blackest. The major was smoking a cigar and the smoke took me back to Balliol JCR, Campion Hall, and the Dôme. Temps jadis.

Archie (the Beating Heart of the Battalion, Leckie's batman and chief of the Officers' Mess orderlies) calls butter 'Caledonian Ointment'.

Finished today Rom Landau's 'Love for a Country'. Didn't care for it much even though it did take me back to my pre-war intellectual era. There is something about that constant harping on the need for 'spiritual' regeneration which irritates. Besides a book which tries to compromise between a newspaper system of interview and the philosophical system of exposition is bound to be a mess. And he uses and misuses too many abstractions like culture and civilisation uncritically and without definition.

Am now reading Viscount Samuel on Belief and Action but have not got beyond the usual 'simplified plain man's version' of electrons etc.

Notice on foot inspection that New Zealanders' feet are appallingly ugly and misshapen. Can only be due to what Ron Stewart calls 'hick' shoes. Yet what can be done? The same old cycle. The hideous shoes would not be supplied if they did not have their suburban apache fashion. The fashion might not be created if it were not for the advertising of the suppliers, and in any case the whole thing is only part of the immense complex of ugliness which is cancering our time.

At times as I sit in the mess my heart sinks at the banality of conversations in which at other times I might take an animated part. The dreariness and ugliness of it all and I a stranger thinly disguised. The complacency of these fellows with their talk of 'wogs' and 'niggers' in the centre of a civilisation which however squalid retained its integrity for centuries.

The chief quality of this country seems to be persistency. Flies, persistent everywhere, are here more persistent than anywhere. Beggars «,» thieves and hawkers are the most persistent in the world. (The man who brought a chicken into camp, let it go, chased it into a tent, caught it and disappeared with a rifle. The little boys who followed us today for two miles through a sandstorm without selling anything.) One must be

$\mathbf{1 2}$ 'simplified plain man's version'] 'simplified plain man's version $\mathbf{1 6}$ fashion ] fashion $\mathbf{1 7}$ suppliers ] sup liers $\mathbf{2 6}$ the] thw

1-2 the smoke took me back to Balliol JCR, Campion Hall, and the Dôme ] Places Davin remembers as emblematic of luxury and refinement: the Balliol Junior Common Room; Campion Hall, the Jesuit hall at Oxford; and the Dôme Café, Paris.

2 Temps jadis.] Times past.

3 Archie ] Archibald 'Archie' Crawford (1886-1964) Leckie's batman. According to Bassett, 'He answers to the name of Archie, stutters terribly, pads round in slippers, and of course as our houseboy is universally referred to as Honorlable Archie [sic] ${ }^{\text {,209 }} \mathrm{He}$ was a metal-worker who enlisted in Dunedin.

5 Rom Landau ] Romauld 'Rom' Landau
(1899-1973) Islamist of Polish origin. His Love for a Country: Contemplations and Conversations (1939), written 'In humble gratitude for all that I owe ENGLAND', was a combination of musings and journalistic profiles of individuals.

11 Viscount Samuel ] Herbert Louis Samuel (1870-1963) Liberal politician, first High Commissioner of Palestine. In Belief and Action (1937) he tried to define 'an everyday philosophy.'

16 apache ] urban and unsophisticated (originally from a slang term for Parisian criminals.) 
persistent to live here. The goats and donkeys graze where only patience could descry anything to live. The few trees surviving survive with nothing to aid them except their determination. And the dirt the squalor and the sand the old way of life the culture of the desert village persist with the tenacity of time itself.

The candle famine has at last been terminated and we are all at our various scripts by the light of candles stuck in bottles. Rex is lying on the flat of his stomach writing to his Mary. Lo, a Messiah: the Major has just appeared with four bottles of lager (that it should have come to this and me welcome lager!). He was driven to this by the sight of the desperate Sandy drinking water.

'A ruined world, a globe burnt out

A corpse upon the road of night.' Richard Burton.

\section{Sunday 23 rd March.}

Still here: nothing much happening. Heavy rain the night before last and leak in the tent disturbing sleep. Yesterday showers and duststorms alternately. Found one man in my platoon from reinforcements who had never touched a Bren, another who had never fired a rifle. Yesterday we cooked a dozen eggs and had a feast

\section{March contd.}

of eggs, beer and gin. Bed at ten o'clock. A late night

Church parade this morning over at the NAAFI among the broken bottles and metal caps. I was looking down at the ugliness in the sand when suddenly it fell into a pattern and was not ugly at all. Route march after mass and so home again. This afternoon Cunningham and I will go for a walk

Wrote this in our last camp unfinished

Morning Fatigue in the Canteen.

In timeless attitudes and modern khaki

They sat gravely at fatigues, and high ceilings

Echoed with the empty melancholy

Of canteen piano wheezing and sad

7 Mary] Not identified. King's next of kin was his wife, previously Joan Lane Taylor. ${ }^{210}$ 11 Richard Burton.] The quotation comes from his Sufi-influenced The Kasidah of Haji $\mathrm{Abdu}$ El-Yezdi, supposedly a translation but in fact an original work. 15 reinforcements ] The Fourth Reinforcements (actually the first not bringing new units) began arriving in Egypt from 16
December 1940. ${ }^{211}$ Davin's inexperienced reinforcement probably came from the second section, which arrrived at the end of January, since reinforcements seem to have joined 23 Battalion around 7 March. ${ }^{212}$ 20 NAAFI] Naval Army Air Force Institute; a welfare organisation which ran shops and canteens. 
Where last night upon the glasses laughter rang.

Swept into a corner now

Its ghost with the litter of rejoicing

The broken, dirt-filmed glass, the butts and packets.

The smoke has left; that smoke whose night-soured strand

Drives now before the broom.

And empty bottles packed in rows

Burnished and hollow of their gaiety

Fled with the death of laughter.

These tend the birth of others' nights, not weep their obsequies.

\section{Later. 7 p.m.}

Went for a walk this afternoon with Gordon Cunningham, half in search of some rumoured tombs. We walked along the lagoon side of the ridge on a new road. The pleasure of walking after these months of marching! To be able to stop beside the ants' nest and watch the great black ants with coppery skulls toiling up from the hole, loads of earth clutched in their pincers, then dumping the burden around the upper lip of the saucer which surroun[d]s the whole. And the great overseer ant walking about the outer base, gravely scrutinising the foundations. To be able to smoke when one pleases, not to bother about step, or line of march, or men. If only we knew Arabic and were able to respond in kind to the grave saida of the passing men. These are different types from the spoiled ones who trail our line of march, incurious, proud people bent on their jobs, timeless beside our temporariness - men who who were there before this war and will be here thousands of years after. They make the bible a book of the present and their strange flocks lend significance to its phrases - separate the sheep from the goats would be a difficult job alright when it is difficult even to distinguish them with the eye. Of the women you see little, they avert their eyes as you pass if they are so unlucky as not to have time to dive into their camps. Their tents are very low to the ground, old and much patched and yet though the tent should be a symbol of the migrant, these have a community with the scene which gives them an appearance of permanence in the shifting sand. And occasionally the dusty oasis won by labour from the sand and kept only at the same unremitting price. A woman stepped across a stone wall, her red skirt a vivid foil to the weary greens about her, a pitcher on her head, her walk as slow, rhythmic and unhurried as Miltonic blank verse. And yet even there I thought as we watched rudely something of the selfconscious woman's vanity swayed her hips ever so slightly and gave her breasts a fuller blossom.

A shepherd with his back to us walking towards his flock, the antique wooden machinery of [a] well, the earthen banks of a garden shored against the invasion of 19 to bother ] tobother

20 the grave saida of the passing men ] The annotation to a poem in Return to Oasis gives 'Saheeda' as 'A greeting when we would say 'saieda' as 'hullo, good day!'214 
the sand, all have the air of eternal parable. Tenacity and parable seem to be the characteristics of the desert country. The struggle against elemental

\section{March contd.}

forces is nowhere so explicit and the very permanence of the culture is a memento mori. Wrapt in the struggle for life there is here the peasants' indifference, not conscious enough for cynicism, to the going and coming of governments. In a way seeing them superficially, one no doubt romanticises these things and yet just by lacking the intimate knowledge one gets the general perspective as we may discern from a distance the pattern off a mountain chain. And sometimes especially in allegory the truth is what one sees, since the symbolism is so much subjective.

We crossed the ridge over the stony traces of water-courses which in their hour must run tormented down to the salt lagoon. Across the ridge lay the new transient world. The world of tents alien to the soil, of soldiers clothed scientifically not traditionally, to the climate inoculated not immunised against the indigenous diseases, restless wandering men, not wandering in the manner of the vagrant tribes, but men restless in their souls, carrying their seething modern agitations half across the world, seeking to resolve their personal battles in a war not intellectually their own. Now the scenes of war: a man sitting in a latrine of scrim silhouetted and ruminant against the sky. An Australian private with fixed bayonet, his insolent hat curved defiantly to the wind, guarding a water tank: brown white bodies of his comrades bathing at the taps, their flesh flashing in the late day's sun. Along the roads in groups of twos and threes the other huckster Egyptians sitting with their wares, patient and vociferous in their lack of expectation. The Maori Battalion grouped and smart listening to a lecture, dark and indigenous but not to this. Columns of men winding their way towards cookhouses, pannikins swinging, knives and forks clattering. As far as one could see, the tents, silver in that strange light, reminiscent of nothing so much in their colouring as the barrage balloons of London. In the remote distance the village of our camp, forbidden to us because of the typhoid rampant there.

And all this camp, this machinery for living, could be taken up and gone tomorrow and in a matter of days the desert would have covered up its traces.

15 the ] th e 15 against ] adainst

19 scrim ] Thin canvas; the OED uses Davin's line (from The Gorse Blooms Pale) 'A man sat screened by scrim on the latrine' as an example.

27-28 the barrage balloons of London ] Barrage balloons were balloons floated to force enemy bombers (which risked collision with their cables) to fly higher. 30 this machinery for living] Possibly a reference to Le Corbusier, who in 1923 declared 'Une maison est une machine-à-habiter.' 
Nearer home met Jack Allen, last seen in London with the Priors when we visited the pub on the Thames.

Tonight five dozen eggs and beer to be devoured. Rex has been practising the three-card trick and succeeded in winning three loaves of bread from Digger the mess orderly. A rotten meal we had tonight: rice for a second course (Shanghai ballast, Archie calls it) and no butter (Caledonian ointment, says Archie.) Worst of all, a queue. I hate queues from the bottom of my heart. Oddly enough the English seem to love queues. I have seen them lining up for hours to save sixpence on a seat and even then, at the usual hour of opening, still cheap seats to spare. It seems almost as if they take a delight in practising this sheeplike patience which is now so useful to them during the air-raids.

Have been reduced lately to smoking Woodbines, the free issue cigarette. I had meant to save mine for the platoon, but my ship's cigarettes gave out. Tonight however Ginger has brought me a hundred Player's.

Poor Ginger is having one of his bad runs. Was found drunk in Cairo and kept all night at Maadi by the MPs. Now serving seven days pack drill and having narrow escapes from other troubles. The Major has instituted a latrine guard on the principle of filth to filth for those caught swearing. And Ginger was very nearly the first victim.

Rumours and counter-rumours of our movements. I have my own theories as to our prospects but it is hardly worth prospecting. Suffice to the day: a soldier cannot afford to be imaginative.

The time for the feast is close and I must to the latrine,

$[15]$

\section{March contd.}

cleansing the temple for the arrival of the eggs.

\section{March.}

Morning a route march; went through what must have been a sort of weekend colony for Alexandrians. Now occupied by Australians. One little house in particular rather pathetic: plastered with those sentimental little notices one sees in such places all over the world: 'A chi la barrachia? A noi.' 'Nel fresco e ludo nostro.' 'E meglio 30 vivere uno giorno nella allegria che centi anni in miseria.'

\footnotetext{
9 seats ] sets

1 Jack Allen ] Not identified.

1 the Priors ] A couple, Arthur Norman Prior and Claire Hunter, with whom the Davins briefly lived just before the war began. ${ }^{215}$ Arthur had written for Critic at the same time as Davin in Otago. After a New Zealand education, he taught himself formal logic and worked at Manchester and Balliol.

4-5 Digger the mess orderly] Not identified. 16 MPs ] Military policemen.
}

30-31 A chi la barrachia... centi anni ] Translation of these phrases is made more difficult by the fact that they are very badly copied, with several errors. If we assume that 'barrachia' should be read as 'baracca', hut or shed, a loose translation would be something like: 'To whom will the hut go? To us' 'Play our games in the cool.' 'It is better to live one day in joy than a hundred years in misery.' 
This afternoon a company stunt - rather bad from one point of view because I made several bad mistakes but good from another because I learnt something from them.

We move tomorrow. All very hush-hush. Rex and I and two other officers from 5 each company travel with another battalion. Odd, and even irritating but I am reacting more to the mystery than to the irritation.

Wrote home to Winnie and home to NZ and got them off tonight.

Now to packing: it will be a queer old day tomorrow.

\section{Thurs 27 March. At sea. [ - on board Ionia]}

Bn moved out on Tuesday. Rex and I got a lift to Alexandria for the day but as nearly all my money was in my paybook, once again unable to send any home. The ride to Alex was the roughest I've ever had, an Aussie driver. Alex is a much more attractive city than Cairo, though not being there more than a couple of hours we did not see much of it. Came back in a taxi with three sergeant-majors drunk. Like all NZers they 15 were very tiresome in their cups with the intolerable arrogance of complacency.

Out of bed 2 a.m. yesterday morning to pack, breakfast and train. Night march through the desert - one poor devil fell in a slit trench — to the station. Before leaving Rex and I fried eggs in an old dixie, boiled water in a couple of old waterbottles and made coffee, very necessary because all the breakfast had been eaten by the time we got there.

Train journey was interesting: sunrise on the desert; infinite variety of beggars etc. Made Alex about ten, were buggered about for a couple of hours and finally embarked. Bought paper - Yugoslavia gone as was to be expected.

Rex and I in a terrible cabin, palliasses revoltingly dirty (Greek ship much too small for our numbers). Furious complaints finally brought a fellow with sheets and pillow slips which he put on over the filthy mattresses. However, we had a porthole so Cunningham has come to join us.

As we had been short-paid arrived on board with five piastres. Met Padre Sheehy who lent me 200. These I lent out and what with loans and the drinking of cognac and 5 reacting] reaacting $\mathbf{1 6}$ yesterday] ye terday

17 a slit trench ] A narrow trench. Here dug for protection from air attack.

18 dixie ] An iron pot; the slang comes from Indian servicemen.

23 Yugoslavia gone as was to be expected] Davin is not referring here to the invasion of Yugoslavia, which would take place in a few days. Exactly what he means is more ambiguous, and depends on how quickly information reached him. He most probably refers to the announcement of a pact between the Axis and the Yugoslavian government on the $25^{\text {th }}$. On the early morning of the $27^{\text {th }}$, however, pro-Allied Serbian officers carried out

\author{
a coup d'état in response. This news was \\ printed in British newspapers on the $28^{\text {th }}$ of \\ March. $^{216}$ \\ 24 palliasses] Straw-filled mattresses. \\ 28 Padre Sheehy] William Sheely \\ (1907-1986) A Catholic priest from Te Kuiti or \\ possibly Cambridge attached to 21 Battalion. \\ He escaped Greece with Macky's party but was \\ evacuated sick from Crete. ${ }^{217}$ \\ He was captured along with most of the New \\ Zealand medical services near Wadi \\ esc-Sciomar during the attempt to relieve \\ Tobruk in November 1941. Although most
}


whisky am practically broke again today.

Yesterday lived almost entirely on bully beef and brandy. Went to bed about 11p.m. So had been up 19 hours. But because of all the sleep and the healthy life in the desert am quite fit and frisky this morning. Had bath and treated myself to a new razor blade this morning. The bath fantastically dirty with the usual complicated continental box of tricks in tappery and the usual difficulty in extracting water. The whole ship is astonishingly dirty but we should be off tomorrow afternoon and it's pleasant to be at sea again.

Rex has got it into his head to learn Greek and has appropriated the rather tinny book I bought in Aldershot: but I must do some myself today.

Am sitting now in my upper bunk beside the open porthole with the Mediterranean flowing by. I have a flea but the chances

[16]

\section{March contd.}

of catching him in the remote jungles of my battledress are so slim that I must just suffer until he domiciles himself elsewhere, unless a lucky chance should deliver him into my hands.

Watty Mackay is on board so may get a good game of chess.

Don't like this expedition much: we're bound for Greece, I imagine, but I have my doubts as to whether we can hold Greece in the long run. Suffice for the day however. I am homesick for Winnie too -.

If this boat should sink our chances of survival are about nil. The lifeboats couldn't hold a quarter of the men and with my hatred of crowds and queues I doubt if I could bring myself even to try to get aboard one.

The men are living in colossal discomfort but seem pretty cheerful. They like to be going somewhere.

\section{Fri 28th March.}

Last night had ship's orderly duties from midnight till 4. Row with Caldwell (OC stray officers) in the afternoon because I suggested that with so many officers two hour

$\mathbf{1 6}$ himself] himself. 19 for ] forr

were soon released, Sheely had volunteered to accompany a party of walking wounded to Benghazi and spent the rest of the war imprisoned. ${ }^{218}$

After the war he was the parish priest at St. Patrick's, Pukekohe. ${ }^{219}$

7 astonishingly dirty] The Ionia had been recently used to transport sheep. ${ }^{220}$

10 but I must do some myself today] Sandy Thomas remembers being impressed with the attention Davin paid to learning Greek on board and asking him about it; Davin said "'Greek children can do it. Why shouldn't I?" And by the time he got to Greece, he could speak Greek. ${ }^{221}$

28 Caldwell ] Edward Caldwell (1904-1985) A bank officer from Hamilton, captain in 1 Reinforcements who trained along with 23 Battalion and left New Zealand with them. He was captured in Crete. 
shifts would have been possible: The man is mad, in all seriousness I say it. There will be grave trouble with such a man. He is too crazy to be in a position of responsibility.

In the evening played chess with Watty (lost 6 games out of 7), read Freud, and helped Watty with Greek till my shift was over. No grog as supplies were temporarily 5 exhausted.

News came that Yugoslavia had re-formed its cabinet, Keren and Harar had fallen.

We are now 24 hours behind time because the ship returned on its course for 12 hours. Preceding convoy bombed yesterday morning.

Very tired today: did not get up for breakfast. Gordon and Rex brought me down boiled eggs, bread and tea. Awakened at nine by water pouring in the porthole. Sea running high.

Everyone has developed a mania for trying to learn Greek. Rex gets a few phrases out of the phrasebook, then lurks in ambush like a footpad for a Greek sailor to go by: whereupon Rex springs out and tries the phrase. All over the ship the Greeks are being 15 pursued and having scraps of Greek wrung out of them.

Costello is aboard but I haven't the energy to go and find him.

I am lying in my bunk where I have spent most of the afternoon asleep. Owing to this morning's inundation I have had to make my bed out of lifebelts, the cork of which keeps out the water in the soaked mattress. Gordon is sleeping in another bunk. 20 Rex is lying on his, muttering Greek phrases, like a madman in a private world. None of us has been sick though the rough weather has found out a good few.

Have had my copy of Freud's Psychopathology of Everyday Life pinched. Pity, as I'd just begun it and was finding it very fantastic. Have been reading the first of Ovid's Metamorphoses instead. About Deucalion and Pyrrha appropriately enough.

10 nine ] nineb 12 Greek ] greek

6 Keren and Harar had fallen.] Towns in East Africa which were the main points of the Italian defences there; 'Their defeat, the spokesman added, might well lead to the general crumbling of the remainder of the forces at the disposal of the Viceroy, the Duke of Aosta, and at least it was a tremendous blow to Italian morale and prestige.' ${ }^{222}$

16 Costello ] Desmond Patrick 'Paddy' Costello (1912-1964) Perhaps Davin's closest friend in future; at this time, a Cambridge graduate who was a lance-corporal in the Auckland battalion.

16 aboard but I haven't the energy to go and find him. ] Ovenden explains that Costello was already famous in the Division; but this fame would come with his escape from Greece, much later. In his memoir of Paddy Costello, Davin describes himself as actually recognising
Costello 'on the second day out', and having heard of him from Forsman. ${ }^{223}$ Davin had almost certainly also heard of Costello from Cox: he had been in Cox's platoon, ${ }^{224}$ and it was Cox who eventually introduced them. In any case, Davin did not speak to Costello: 'Some timorous instinct and something in his demeanour told me that if I, a one-pipper, were to accost him he would not be able to resist snubbing an officer.'

24 Deucalion and Pyrrha appropriately enough ] Ovid's story is a parallel to the Flood myth. Ovid emphasises how water swept away 'homes and shrines and household gods';25 Davin's inunduation echoes this, and Deucalion and Pyrrha's experience; like him, they will land in Greece from a storm-tossed raft. 
Fine phrase: longique perit labor irritus anni

We should get in tomorrow morning sometime. I shall take some pleasure in seeing Athens.

\section{Saturday 29 March.}

[(typing Sat. 31 March, 1979)]

Everyone is getting desperate. We should be in port about 8 tonight but probably won't land until tomorrow. In the meantime there is practically nothing to eat, no-one has a piastre because money is short, cigarettes are running short and there is nothing to read. Yesterday afternoon there was a spurt of excitement when an Italian plane passed over and dropped a torpedo but of course when I

\section{March contd.}

arrived on deck it was all over. The Greek captain couldn't understand the universal donning of lifebelts: 'only an Italian plane'.

At the moment $\mathrm{R}$ and Brough Bond are squabbling over a copy of The Gay Parisienne. B's copy had the last few pages torn out and he had to come down to find out what the ends to the various stories were. Cunningham has disappeared with the Greek Grammar and I am engaged for the afternoon in reading Ovid and sleeping.

We passed Crete this morning and since then many odd rocks and islands, following widdershins the tracks of the old Athenian fleets on blockade.

News has come to pack up. Probably vain effort and we shall stay here. Rex says he would sooner spend the night marching or on the train. Certainly it is a hellship: even the mess waiters bully us and the grub is the most inadequate I've ever had since joining the army: bully beef and biscuits in very small and unpalatable quantities.

Night Before Athens.

Pack up the baggage once again,

Again dissolve our world, create anew

A universe, perfect and impermanent

As ripple-pattern; let the new life

10 I] I arr

1 longique perit labor irritus anni] The useless labour of a long year has perished: after all the waiting, the battalion is going to war. The phrase is used before the flood in the Metamorphoses when farmers' crops are destroyed by rain.

15-16 The Gay Parisienne] Not the Edwardian comic opera. Gay Parisienne was a North American ‘spicy pulp' magazine.

20 widdershins ] in a reversed direction. 20 the old Athenian fleets on blockade ] Davin does not seem to be referring to a particular event here, but rather the seemingly endless efforts of the Athenians to keep the Delian league quiescent during the Pentecontaetia. Alternatively, he possibly remembers the Athenian invasion of Egypt, but this was not a blockade. 
Break the old as dawn the dream,

And out of the chrysalis of this self

Soon dead come forth next

Weaving itself a fresh complex

Bonding habits must be broken and new bound

Until the last of all our worlds

Is ours, that habit of eternal stillness,

Our last chrysalis, the grave.

\section{Later:}

It is $10.30 \mathrm{pm}$ and we are waiting up in the lounge for orders to disembark. The approach to the Piraeus was magnificent. I have not been so stirred by a place for a long time. Rumours current that Musso is dead but lack confirmation.

\section{Sunday 3 oth March.}

Sitting in a park of a sort of fir trees near Athens. We disembarked about 10.30 and waited till 1 a.m. sitting on the footpath, profoundly dejected and cursing Movement Control. Finally got into trucks and rode to our destination but one truck got stuck as we were coming in. General cursing and vast confusion. Got out and walked rest of way. Our guide, Major Lelevre (Tailspin Tommy) got in a complete [(?)], kept leading us over a jungle-like maze of tentropes to tents that were already full. At last in despair we lay down in an old tent and made ourselves uncomfortable for the night. Three hours sleep and woke at five, miserable with cold. A little of this and Rex and I could stand it no longer. We got up and walked. It was just after dawn and Athens was beautiful, the dawn tones suited the houses which are made of stone with a strong pink tinge. We picked up a benighted Cypriot driver whose military truck had broken down during the night. He could speak only Turkish and a little English. Salvaged him and got him fixed up. Back to breakfast of bully beef, hard biscuits and tea.

Swarms of children about the camp, very intelligent and charming. Some of them carried our bags and their leader would not take any money. His boots were in a terrible

13 Rumours current that Musso is dead but lack confirmation.] Probably these rumours were a garbled form of the naval victory at Cape Matapan over an Italian squadron intended to intercept the troop movements to Greece.

16-17 Movement Control] Movement control organised transport to avoid congestion; this often entailed long waits or deliberately slow movement.
19 Major Lelevre (Tailspin Tommy)] Clement Auguste Le Lievre (1891-1974) Officer commanding B Company, 21 Battalion, a farmer and First World War veteran from near Edgecumbe. Davin probably knew of him because Keith West-Watson was one of his subalterns.

Tailspin Tommy was the pilot protagonist of an American comic strip. Le Lievre's son does not remember his father having this nickname. 
condition and he cast envious eyes on my spare shoes but I was able only to give him some boot polish and a balaclava.

Later we went down into the village and had some beers. Notice: 'Beer, good as Waitemata, (almost).' Bought E $\lambda \varepsilon \dot{\theta} \theta \varepsilon \rho o v$ Bí $\mu \alpha$

\section{March contd.}

but no confirmation of Mussolini's death. Village poor, populous and delightful. Pleasant to feel so popular.

Our battalion has gone and it looks as if we must hang round all day without money, without leave and without information as to when we must move. Only consolation I have managed to buy on credit some Players from Alf Moodie. Now morning midday and a fresh lunch of bully beef and biscuits. Yesterday wrote a short story about the old days of the milk round. Very pleased with it and may sell it to the Manchester Guardian. Same characters as in Toby. Return now to the former occupation of sleeping squalidly in the sun or discussing interminably and vainly the chances of leave and methods of raising cash. Greeks seem heart and soul in this war.

\section{Thurs 3rd April. Olympus.}

Seated in the sun on the top of a ridge of hills running up to Olympus. Got leave in Athens on Sunday but too late to be of much use to us. Shops closed and could not send any money. Had rather a dull evening and got very depressed. Monday morning spent in packing up once more and on Monday [//31 March//] afternoon caught train for Katarene. All night in train and fitful sleep but trip very interesting. Reminiscent of NZ in a biblical sort of fashion. Great ovations from Greek children en route. Very handsome Gk Sgt-major in the train returning from sick leave. Had been wounded three times but was in high fettle. Stopped at Larissa where we managed to get hold of some Gk beer, excellent. Arrived Katarene Tuesday 1 April, no transport, no instructions. Luckily R. knew Town Major well. He fixed up billets for us. R. and I landed with widow and two daughters. R. $\mathrm{v}$ disappointed at rigid Gk proprieties. But in any case language difficulties terrible. Bought couple of grammars and borrowed some books. Went to bed about 9 o'clock tired out. Up again next day much fresher, breakfast of six eggs, chips, and bottle of cognac. C Coy truck turned up to take us here.

3 Notice: ] Notive: 3-4 'Beer, good as Waitemata, (almost).'] 'Beer, good as Waitemata,(almost). 25 to ] to 26 Tuesday 1 April] Tuesdayı April

3-4 good as Waitemata, (almost)] At the time, Dominion Breweries made a beer named Waitemata Sparkling Ale at Waitemata,

Auckland. At Tobruk, engineers named three

barges after favoured drinks: Waitemata, Tui and Hokanui (moonshine). ${ }^{226}$

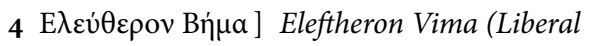

Tribune); a centre-left newspaper, now called To Bíна.

12-13 a short story about the old days of the milk round ] Published as 'The Milk Round' 14 Toby] The precursor to 'Death of a Dog', which had already been published in the Guardian. 
Wild trip, latter part along road built a few days ago by $20 t h$. Sanatorium, German-run, below us.

Village on my front where I shall practise Gk when I get time to learn any more. Trouble is lights forbidden after dark and little leisure before then. Better perhaps now 5 we have a tent up.

Bitter cold last night though day weather superb. We shall have nothing up here except magnificent scenery. Opportunity to grow healthy and rich.

Tinkling of cow-bells give whole place air of Sabbath calm. Quite picturesque village: little indication that old Greek heaven might soon become modern Greek hell.

Have been tramping hills all morning and reviewing positions and am now rather done. Have stolen this rest in spite of the impending visit of the brigadier but hope to be back in my area by the time he arrives. Too tired now to write further beyond reminding myself that last night I thought of a poem, running roughly for a start:

We are imprisoned in infinity and God's hand, the sky, is closed upon us.

Tented by God's night -

Will finish it when feel more fresh.

\section{Sat 5th April.}

4 o'clock in the afternoon. Sitting in a quiet gully on the slopes leading down to my area. The men have gone back for pay. This morning spent blasting out stones from trenches and generally preparing positions. Brigadier supposed to come yesterday, day before, and today: but like tomorrow, he never comes.

\section{April contd.}

This afternoon spent mostly [sitting] in the shade, doing Greek, with an occasional tour to see how things were going. Position assuming shape.

Got hold of Greek newspaper yesterday: Count Teleki suicide. Benghazi retaken.

Others got letters from NZ yesterday. Me none. Consoled myself $\mathrm{w}$ the reflection that it is best to forget about letters; then the arrival of a letter is like the acquisition of a new friend.

19 o'clock] o(clock 25 the] the 27 of] ogf

1-2 Sanatorium, German-run, below us. ] This was the Petras Sanatorium, on the lower slopes of Olympus. $^{227}$

3 Village on my front ] This was Lokova. ${ }^{228}$

27 Count Teleki ] Pál János Ede Teleki de Szék

(1879-1941) Count Teleki, the Hungarian

Prime Minister, committed suicide after the
Hungarian invasion, in breach of a recent treaty, of Yugoslavia. ${ }^{229}$

27 Benghazi retaken ] Benghazi had been captured from the Italians in February; its recapture by the Afrika Korps was one of their first victories in North Africa. 
See now why Gk pottery is red: the earth everywhere is red.

Wondering constantly where and how are Winnie and Anna: no news since Egypt. How Winnie would love the little green lizards that are everywhere. There is one peeping out at me now from a bushy rock a yard away. Every time I move he gives a wild jerk and then peers out again. There are snakes here too and slow tortoises.

The men are at their best now with work they know how to do and the prospect of a fight. Only I am gloomy, I don't quite know why. But I have not felt cheerful since leaving Egypt. Still as time goes on and if the Germans do not come too soon I shall have time to read and learn and perhaps to write a little. And now I must tramp the mile up the mountain and help with the pay, leaving the slopes, the sheep and the active little goats to wander among the lizards.

\section{Sunday 6th April.}

Dodged church parade this morning and went over to D Coy to liaise w Bond. Took wrong road and landed at D Coy O.R. where found them preparing for church parade. Chat w Cunningham, Harvey, Bond etc. Two beers. While there learnt that Germany had declared war on Greece and Yugoslavia - latter for Non-Aggression Pact w Russia, which is rather puzzling. Gunfire heard this morning and intermittently all day now accounted for. Salonika probably being pounded. And I have the forward platoon.

Still we have been expecting it long enough. Summoned down to Bn today to talk 20 to a Gk. Some queer monkey business. But there was no help to be given at this end.

Have grave doubts as to the expediency, though none as to the obligation, of trying to hold Greece.

Ever since coming here seem to be off colour: almost retched after tea last night. Lot of dysentery about.

Outside the tent the AA posts are manned. I have been reading Vardis Fisher's Children of God: the usual massive American epic, overloaded with detail, picaresque on the mass scale instead of individual, but with a tale that would be interesting, however told. One of the things that depresses me is the constant reminder in it of man's inhumanity to man. What is incredible to some is only too credible to me.

I wonder if Winnie and I shall ever meet again. If the Hun column comes this way I have a notion we may stop it but it will cost many of us our lives. However.

Today as I saw the dead leaves under the springing green I felt my old anger with the patterned futility of it all and wrote but not well, because an old Greek came and interrupted me as I wrote:

A Hope Against Hope.

\footnotetext{
$\mathbf{6}$ do and ] doand $\mathbf{1 4}$ landed at] landedat $\mathbf{1 4}$ preparing] prparing $\mathbf{2 9}$ me is] meis

26 Vardis Fisher] Vardis Alvero Fisher (1895-1968) American historical novelist. His 1939 Children of God was a tripartite epic 
Can you not see poor spring, the rotting leaves

Of last years spring? Their dead brown months should choke

Your budding hope. And yet you dare out-thrust

The tender challenge of your green, ignore

The chain which binds you to the winter gone

And to the doom before. Ambitious tree,

So rooted in the rot of last year's hope,

Whose present pride will nourish hope as brief

In futile, fated rhythm till the end

\section{April contd.}

Of time.

Bound too am I. My joys will die

In griefs, wise pain succumbs to hope. Our life

Enslaved swings like a senseless pendulum.

The anguish of our desperate hearts is nurse

To ecstasy; disaster suckles hope,

Until at last at one with rotten leaves,

Though flesh should feed its sap to other life,

Our minds at least are stilled and one

With yesterday.

\section{Tuesday 8th April}

All day have been down $w$ the platoon in the rain and yesterday as well. We knocked off early today because of the wet. I am writing this on the top of a Tommygun chest in our tent. Major Thomason «,» Rex and Sandy are playing euchre in the corner.

Not much news is filtering through from the front but one gathers we are holding our own, pushed into Bulgaria [(?Monastir)] a bit though probably not for long. Attitude of Turkey and Russia dubious.

Father Henley turned up last night: my father is the same as ever apparently. Mollie Gonley the happy mother of children. It appears that I am to bury any dead RCs in the battalion. The irony of these RC incidents.

$\overline{24}$ because of] becauseof $\mathbf{2 9}$ turned ] $t$ urned

29 Father Henley ] James Francis Aloysius Henley (1903-1981) A Catholic chaplain, padre to 5 Brigade, who had arrived with the 3 rd Reinforcements. ${ }^{230}$
29 my father] Patrick Davin (1877-1958) 29-30 Mollie Gonley] Mollie Baird (?-?) Winnie's sister. 
Kennedy yesterday when I told him the West Coasters must dig their gardens with gelignite: 'No good doing the barking, sir, when you've got a dog.'

Typed out a short story yesterday to send to Winnie. Hope to get into Katerini soon to send her some money.

Don't know what I'd do for food these days if it weren't for the constant supply of eggs from the village. Have lost all stomach for army food. Eat an enormous number of dried figs. The healthiest life I've lived for years. No liquor at all available except a bottle of beer about once a week and constant tramping up and down steep hills. Boys all in a good temper with plenty of work to do and the prospect of a fight.

Must move over to censoring letters now. Very dull job guaranteed to cure any inquisitive village postmistress.

\section{Friday 11th April}

Village partly evacuated today: so moved cookhouse in to one empty house and platoon HQ into another w battle HQ ready for immediate use if trouble starts. Have been expecting trouble daily, urgently contemplating defences in the rain, everyone working at top speed. Now practically ready though have the most dangerous posn on front. AT moved in today, NZA behind us., MGs etc so at least we will have some support. Now have hopes of getting out alive. Good but vague news tonight: situation has eased in some mysterious manner. Am sitting on hard bed in small Gk cottage. Sgt Dutton and Ginger are frying liver and eggs preparatory to a before bed. It is 9.30 p.m. This is terrific luxury for us as we have passed the last few nights damply under a tent fly. Rain has been pouring day and night and I as well as everyone else have been soaked 24 hours of the day.

This morning had to turn back Gk refugees fr the Sanatorium and sent them off down the right flank to the coast. They were very patient and pleasant people to deal with. Everywhere I go I admire the spirit of these people. This morning just because I took a little trouble for them even though I still had to turn them back they shook hands and said through an old Gk back from America they were very grateful because I had treated them with

\section{April contd.}

\footnotetext{
8 hills. ] hills..

2 'No good doing the barking, sir, when you've got a dog.' ] Clearly a common phrase in the 23rd; c.f. Angus Ross on Reg Romans: 'On the administrative side of his office, he frequently assigned tasks to the junior officers best able to execute them. In the idiom of the Central Otago sheep-men he knew so well, he used to say: "I don't keep dogs and then do the barking myself.",231
}

24-25 This morning had to turn back Gk refugees fr the Sanatorium and sent them off down the right flank to the coast. ] The official history had these refugees arriving, and it is implied Lokova evacuated, on the 9 th April. ${ }^{232}$ Thomason dates this evacuation between the third and the eighth and does not mention the refugees. ${ }^{233}$ 
courtesy like a gentleman. The jargon of language was terrific: their French very bad and English limited to a few phrases. These were mostly semi-bourgeois types.

The villagers themselves are even more courageous. All the men except the very old have gone off to the war. The women and children were withdrawing to the caves in 5 the hills on the right. They went off with incredible burdens, their pigs on strings, their hens tied up and cattle before them. A terribly pathetic spectacle. One old man, blind and deaf, is being left behind because he won't go. The colonel hopes to evacuate him.

This morning much to my anger one of my men too greatly tempted shot a pig. The whole platoon is now in a state of inflamed conscience. The poor old woman who looks after the pigs has been going round calling to it. I would pay her the money but haven't got it. Our men will not touch anything else but I am getting the village put out of bounds to other platoons. These people are so reserved, proud, honest and generous that it would be criminal to take what they have. The village reminds me very much of Ireland - and the people.

Colonel and Brigadier were poking round rather ineffectally today.

Wrote to Winnie and wrote home yesterday. Hope of cabling money to poor Frog gets slimmer. Can't get it out of paybook and couldn't get near a post-office.

Have been working pretty hard but am pretty done tonight with a sore back. Only one man per section patrolling tonight so will let myself off my midnight round. Now have our own cook and are detached and independent.

Hungry for news, news of home, news of war, news of politics. But nothing but rumours.

\section{Saturday 12th April (Easter Saturday)}

Going through old papers found this poem so recopy it:

God's in his Heaven.

Much must be forgotten till joy can course

Rampant in the blood. You must forget those poor

Who grind in dreary toil, the pitiful

Slave's wage, the grime, the salty sweat, the grim

Monotony of soul-destroying tasks

That warp the body too, forget work's loss

That drives weak souls to their last hope, despair;

Forget the whores most hopeless when most happy,

Forget the frequent body-sale, when churched

The bartered bride yields bed for board and love

For lingerie. You must cut dead, or shrug away,

15 poking] oking

6-7 One old man, blind and deaf, is being left behind because he won't go. The colonel hopes to evacuate him. ] Bassett tells the same story, with the addition that he was lame. ${ }^{234}$
9-10 The poor old woman... calling to it ] 'Distraught and weeping, she had gone about the village calling to her pig. But the pig had not answered. Frank had guessed its fate... ${ }^{235}$ 
The humbled beggar's meek request

And importune oblivion to sweep

Aside the mendicant musician's squeal

Of suppliant cacophony: must pass

The outstretched hand of penury and dose

The squirming mind with weak apocrypha

Of hoarded gold, explain the gothic arch

of rich man's justice poised secure on poor

Man's tyranny, the smug reformer's cant,

Palliatives for cures, panaceas

Patent and potent but for wringing wealth

From ailing poverty. You must exile

The grey and gloomy queue of dubious

Tomorrows, dig deep a narrow grave

Lest ghosts of murdered qualms should rise to haunt

Your queasy sleep. And when and if you lay

Such miseries to rest, still the vampire thoughts

[22]

12 April contd.

Start from the murk to suck your peace's blood,

Proclaim your calm complacency, and shrill

The trumpet loud before the toppling walls

Of ivory Jerichoes.

Still the quiet question stands.

Is this weakling joy worth while

That needs, to warm its twisted smile,

Such careful swaddling bands?

At such a question, Pilate washed his hands.

Later.

Refugees are returning and some of our chaps are obliged to vacate their houses: but some are still empty and we still have the school to fall back on. The refugees bring the story that according to the radio the combined Greeks, British and Yugoslavs have bottled up the Germans in Salonika. But am still waiting confirmation. Ginger has just brought in a young collie pup which he is feeding with biscuits and milk. Now comes

5 The outstretched ] Theoutstretched 30 chaps are] chapsare 34 collie ] col ie 
the story that they are still on the mother and have to be taken back. I wish I had a dog again: never had one since leaving NZ.

The rain is coming down again but so long as we can stay here we are proof against it. I have a very sore back - must have been strained in carrying a pack up the hill.

5 Also attacked by some sort of bush-itch which comes on at night and is giving some of the poor fellows hell. [(Fleas!)]

This house consists of one room about 15 ' $\mathrm{ft}$ by $20 \mathrm{ft} \mathrm{w}$ a sort of outer porch and scullery. There is one bed very hard, covered with sacking. Cupboards and fireplace make up the rest: and in it used to live parents and three children. Yet of course in contentedness these people are better off than any Anglo-Saxon people.

Early bed tonight to see if I can get the better of my back.

I wonder where are Martin Braun, Heugh, Arthur, and so many others. Have been reading Bertrand Russell's Outline of Philosophy talked out of the American Express in Athens. Takes me back to the old days when we listened to him in Schools 15 and McClung, Joel, Garrett and I drank beer and talked philosophy afterwards in the Eastgate before its change.

Sois sage, $\mathrm{O}$ ma Douleur, et tiens-toi plus tranquille

Tu reclamais le soir; il descend, le voici.

$\mathbf{1}$ that they] thatthey $\mathbf{3}$ are ] ar e $\mathbf{1 3}$ Bertrand Russell's ] Bertrand Russells

1-2 I wish I had a dog again: never had one since leaving NZ. ] Dogs were an emotional subject for Davin; his father shot the dog-before-last, Glen, and 'the grief of this was a first taste of despair, the emotion born at the death of happiness.' He memorialised him in the short story 'Death of a Dog ${ }^{236}$

12 Martin Braun ] Martin Braun (1904-1975) A German classicist who was a refugee research student at Oxford at the same time as Davin; the author of History and Romance in Groco-Oriental Literature (Oxford, 1938).

There is no direct evidence that the two knew one another. However, the connection seems probable: Davin notes a Martin Braun's address in an internment camp at the same time Braun was interned; when Davin goes to see his Braun in London, again, Braun was there, working for the BBC. Davin's Braun also has enough interest in romance in Graeco-Oriental literature that Davin can make a joke to Winnie: 'Modern Egypt reverses Mark Antony's experience, tell Martin. ${ }^{.237}$
15 McClung ] Mark McClung (1911-1992) A Canadian Rhodes Scholar contemporary of Davin at Oriel College. Son of Nellie McClung, he served in the Canadian Navy then became an intelligence officer in the RCMP. Davin preserved a comic song by Maury Meiklejohn dedicated to him; the line 'Ah, Mark McClung, the night is young' recurs. ${ }^{238}$

15 Joel ] Joel Carmichael (1915-2006) An Oxford friend of Davin's. He was studying Greek there while learning Russian on the side. Davin later published his translation of Nikolai Sukhanov's memoirs. ${ }^{239}$

He was born Joel Lipsky. In later life prominents as a Zionist and author of numerous works on early Christianity, Russian, Arabic and Middle Eastern history, especially for his explanation of anti-Semitism as an inherently Christian construct.

15 Garrett ] John Charles 'Jack' Garrett (1913-1992) A Canadian Rhodes Scholar at Merton. He emigrated to New Zealand and became a professor of English at Canterbury. 
Notes found for an essay:

Romans - no subconscious, Jews produced it and finally produced Freud, the antibody to thou shall not.

Religion lives by dogma: science by progressive destruction of dogma e.g Newton, Galileo, Einstein, dambursters.

Jesuits are beavers, builders of dams around wh rises up the incense of spiritual miasma.

Substance of conversation w Winnie in Anglers Rest, Mytchett Fred and Bob tossing pennies for the existence of God.

\section{Sunday 13th April. Easter Sunday.}

Have done practically nothing today as back though better is still sore. Major down this morning but little news. Fighting seems to have moved away to the West.

Difficulties arising over cow shot by 22nd and pig killed by Smith: must pay for latter and get it done with. Seems probable that the owners of this house will be back tomorrow.

\section{Later:}

evil news for the villagers: they must evacuate by tomorrow morning 9 o'clock as we have mines etc to lay and this place will not be healthy. Brig May and Maj Thomason gave a demonstration

\section{April contd.}

of an AT mine before the mobilised villagers: gt excitement both before and after.

Tonight as I sit here in the gathering twilight they are selling out their fowls and figs, probably to collect their fare to Larissa and Athens. A ridiculous and pathetic spectacle: the poor hens being chased in all directions. Through Evans I have bought

8 Anglers Rest, Mytchett] Anglers Rest,Mytchett 13 shot ] s ot 13 killed ] kil ed 17 o'clock] O'clock

1 Notes found for an essay] This essay does not seem to have been written.

5 dambursters ] Not a reference to the 'Dam Buster' raids of 1943, but to the destruction of beavers' dams.

8-9 Fred and Bob tossing pennies for the existence of God.] Not identified. In For the Rest of Our Lives, a batman and a runner do this. ${ }^{240}$

13 Smith ] Henry Albert 'Congo' Smith (1917-1971) Soldier in Davin's platoon, a sailor who enlisted in Greymouth but had a wife in
South Wales. His fictional counterpart, Jungle Jones, is described as 'The platoon bad boy, a big ex-sailor. ${ }^{, 24}$

18 Brig May] There was no Brigadier May in the New Zealand Division, and no Australian brigadier of that name has been identified. In any case, a brigadier is unlikely to have been conducting a demonstration of minelaying. The correct reading is probably 'Brig Maj'; i.e. the Brigade Major, the chief staff officer of a brigade, here Robert Boyd Dawson. 
six and some figs. I went out for a while but the ridiculous pathos of a toothless old woman trying to sell a rooster for $100 \mathrm{dr}$. was too much for me.

Then there is the other poor old hag whose pig was shot: I asked her how much she wanted and she wanted 1500. I gave her 1000 which was twice as much as it was worth and she called on God to bless me, as a man whose soul was already saved: melancholy mixture of piety and knavery.

There is 'Fucking George' again who not knowing the meaning of his nickname goes round boasting of it. He fought the Italians and got frostbite: but still proudly carries his rifle and bandolier. He wanted me to go down and drink cognac with him but I refused. It would hardly be fair as I refuse to let the boys drink it.

What will happen to the three little pups I don't know but if they are left we will adopt them.

The air is loud with the departing bells of donkeys terribly laden, and of cows being gathered preparatory to being herded off.

What will happen to these poor women, many of them pregnant most of them with little children? Once already war caught them when their husbands went off to Albania and now they too must go. And if their men come home it will be to shattered houses[homes] and lost families.

The rain and the snow have gone now and the valley has never looked so beautiful, with the grass and the young crops so green and the trees in early leaf. And the families motley with their colours and their burdens and their animals wind up along the red track through the fields till past the cemetery where among the trees lie their dead relatives in rough rock graves the road disappears - and even as it disappears suggests unendingness.

25 And we warm from the bleak mountainside are left secure in their vacated homes. Old Aristeides who speaks a little English from having been in America turned up with a tale of having lost his pass: sent him to battalion. Think he's all right.

\section{Later.}

New flap. Germans crossed last obstacle. Attack expected any time. Vigilance etc etc. There's no peace at all in this damned war. Last night it was the refugees who might come back and evict us. Tonight it's the hun. What with watching for fifth columnists (shot up two of our MGs behind the lines last night) and all the rest of it life is not worth living.

Hope to have a little peace from the fleas tonight anyhow. Caught two monsters this morning. Perhaps eggs for breakfast if the hens lay. Perhaps steel eggs for breakfast if Jerry comes.

22 trees ] tress

4 I gave her 1000 which was twice as much as it was worth ] In fiction, the price paid was inflated to three thousand drachmas. ${ }^{242}$ 26 Old Aristeides ] Not identified. 31 fifth columnists ] Greek supporters of the invasion. 32 (shot up two of our MGs behind the lines last night) ] There is no evidence of this event; it was probably a rumour. 35 steel eggs ] grenades. 
Villagers killing their cattle for food on their long trek to nowhere.

\section{Monday 14th April.}

Sitting up in bed preparatory to going to sleep. Germans reached Katarene today: expect attack tonight or tomorrow. Stand-to 5.30. All poss preparations made. Nothing much to do now except wait. We have probably the most dangerous position in the battalion. However even a peaceful man like myself can't be kept waiting 18 months for an enemy without achieving a certain anxiety to meet him.

[24]

\section{April contd.}

The villagers all left this morning: old Aristeides got a pass all right. The blind and deaf man is left below, I fancy.

Was up at Coy HQ tonight: everything very valedictory. Well, tonight, tomorrow, or perhaps the next day we shall see. Sergeant Dutton has just fixed me two grenades. Cigarette shortage threatening. Poor Winnie, at least she doesn't know what's about to break loose.

\section{Saturday 19th April. Molos}

Letter fr $\mathrm{W}$ this morning with fine poem:

In this birth all my deaths [were] buried;

Her least hands, fecklessly clutching and pushing

Loosed the cold grasp of hands

That were laid on my joy.

But now her feckless hand stretch for their fee.

Not only joy, even my sorrow

They demand. I must surrender

Loneliness, and for the milk, my unshed tears.

But my wild grief has flown after you, my love. 5. 1. 41.

The letter was written on the 6th Jan 18 days before the ones received in Egypt. Even so it was good to hear from poor Frog. Especially now when one has returned, at least temporarily, from the dead.

5-6 We have probably the most dangerous position in the battalion.] Their role was 'quite explicitly, to break up any attack before it should come to the main positions of 14 and 15 platoons.' $^{\text {, } 43}$

10-11 blind and deaf man is left below, I fancy] He may or may not have been; he was in For the Rest of Our Lives. ${ }^{244}$ Bassett mentions a plan to 'get him escorted away on a mule as soon as we can find someone to take him ${ }^{245}$ but does not record this ever happening. 
They got forward on Tuesday night (15 April). Slept in Battle HQ, a hole in the side of the cliffs, that night. Constantly awakened by MGs and artillery and by earth falling beside my head down the dugout, an uproar just as alarming.

Wedenesday morning as I feared they filtered in behind the right flank and shot 5 at 3 Section from behind. Quin with some skill drove them off. I applied for a patrol and got them chased out, some staying for good in front of 14 [//Platoon//] Order for withdrawal during afternoon. Arranged for 20.30 leaving hour to to Coy. 2025 word came Quin's section scuppered. Got remainder out in great hurry. Waited on hill in case some turned up. Some of Quin's came in. But Quin, Campbell, Martin, Fisher, to Weir gone.

Then began the terrible trip over the pass. We were all exhausted from sleepless night's vigil in the incessant rain, an ascent under fire of the steep face when with-

4 they filtered in behind the right flank] A group flanked him in 'heavy mist and rain' cutting off Quinn's section on the ridge above the village. ${ }^{246}$

5 Quin ] Arthur Henry Quinn (1915-1941) The corporal commanding 3 Section of Davin's platoon, in civilian life a dredge worker at Ikamatua. He died of wounds the next day while a prisoner.

5-6 I applied for a patrol and got them chased out, some staying for good in front of 14 [//Platoon//] ] Bassett, whose men were the patrol mentioned, implies that the attack on Rex King's platoon was an enemy initiative, not due to the patrol. ${ }^{247}$ In any case, King's platoon were very well dug in, ${ }^{248}$ and the attacks ended after the enemy sustained heavy casualties ('about thirty' ${ }^{249}$ ) attacking them. Davin argues 'that there was no main attack at all, but a series of reconnaissance pushes. ${ }^{250}$ 6-7 Order for withdrawal during afternoon. ] The Greeks on the left had given way, so a withdrawal was necessary to avoid being cut off.

7-8 2025 word came Quin's section scuppered.] The incident is vividly described in For the Rest of Our Lives, where he is called 'Young Playfair.' ${ }^{251}$ Davin sets it out in a letter to Angus Ross; Todd is Alexander Hannah Todd; Inglis Roderick William Inglis. Somewhat confusingly, Alexander Kenneth Inglis, Roderick Inglis' brother, was also in Davin's platoon. Both Todd and Roderick Inglis were privates from Quinn's section: Inglis '(a boy and excitable), Todd's offsider, sprang into the gully. It took a few minutes to get some sense out of him: but the gist was this: the rest of the section was scuppered. Todd had gone off with the Bren in a rage to see what he could do and had told this chap to come and report to me that the Jerries were pouring in. ${ }^{252}$

9 Some of Quin's came in ] The diaries do not mention the sequel to this incident: after getting his men through to Rex's platoon, Davin left them with Dutton and went back (with Congo Smith) to look for any remainders. 'We hadn't gone far when we heard cries.

Eventually we found Todd - almost exhausted but still with his Bren - with him were 3 or 4 others. ${ }^{253}$ According to Davin, Todd 'pretty well saved the skin of the whole platoon including myself although as I thought he was dead I didn't realise it till later on that night when he turned up alive with his machine gun. ${ }^{254}$ Davin's first mention in dispatches was awarded for this.

9 Campbell] Paul Vincent Campbell (1914-1988) Like all the following, soldiers in Davin's platoon. Paul Campbell was not captured with the others but 'went out with a tommy gun to hunt the captured men, and went missing ${ }^{255} \mathrm{He}$ was a salesman from Timaru.

9 Martin ] James Bennith Martin (1914-1941) A bushman from Hokitika.

9 Fisher] Thomas Joseph Fisher (1902-1952)

A surfaceman from Poerua.

10 Weir ] Robert McLean Weir (1910-1970) A labourer from Takaka. 
drawing. Then 12 miles over the Olympus pass, part badly roaded, the rest mere track. Mud $2 \mathrm{ft}$ deep in places. Lost the sole of one boot. Transport cdn't get through so valise, sleeping-bag, overcoat lost. Nightmare trip. Pushed my platoon ahead somehow though never so exhausted in my life. We got there first but lost Dalton en route. Didn't realise he'd got out or might have saved him.

Fresh Huns got over the hills too late to intercept us. We fought rearguard action at Kokkinopolis [//17 April//] and finally got clear to RMT. Food, long ride, then fruit at a dump. Rode all night. Larissa badly smashed. Dead men on roadside, horses, trucks. Greek soldiers making their way back in groups, disorganised, tails down. Little sleep. Drove all yesterday, little food, much buggering about.

Ferociously co[l]d tonight. Sleeping on raincoat under bivvy. Back giving much pain. Now all resting ready for next job. Much gear lost: on the whole a defeat because too few men to too much ground. Might have held but German threat to rear too serious to be ignored. A personal victory since didn't expect (nor did anyone else) we wd get out alive as far as battalion. Pass march took from 21.30 till 05.30 in the morning.

Now we are near Thermopylae.

[25]

\section{5th April Friday. Anzac Day.}

Even travelling through a beautiful strange country one cannot look out both sides of 20 a train.

Am sitting under an olive tree near the coast about two miles from Megara. There are about a thousand wounded here, distributed several to a tree for the sake of cover from the air. Overhead there is a plane and these days all planes are enemy planes. But as everyone has just eaten and the sun is high nobody stirs. In contrast with yesterday 8 horses, trucks ] horses,trucks 19 25th April] 25 th April

$\left.\begin{array}{ll}1 & 12\end{array}\right]$ 'The distance was approximately eight miles but the going made it appear more like twenty-eight to the dog-tired troops. ${ }^{256}$

4 Dalton] Thomas Robert Dalton (1905-1975)

A labourer from Nelson.

6-7 We fought rearguard action at

Kokkinopolis ] It is unlikely that Davin himself was involved in this: 'A Company (Captain Watson) was on the col itself, with a platoon on either side of the path, another in reserve in a hollow towards the centre and headquarters on the track itself. The other companies were below in the deserted village attempting to dry themselves or to get some rest. About 7 a.m., however, they were suddenly disturbed by the enemy, who appeared through the swirling mists about the col and opened fire on A Company headquarters. Some of the forward posts were driven back but 10 Platoon (Second-Lieutenant Begg) of B Company hurried up in time to prevent the enemy getting between A Company and the village. Groups from C and D Companies came up later and the line was eventually steadied after a period of exciting close-quarter work.' ${ }^{257}$ 25 In contrast with yesterday ] Davin: 'I remember in the olive groves where we were a number of Cypriots and Palestinians who were more temperamental than the New Zealanders and whenever we were strafed you could feel these chaps thinking, My God, that tree's bigger than mine and they'd start to run for it, whereupon these fearful New Zealand voices could be heard saying: You bloody fool, lie down or I'll shoot you myself.' ${ }^{258}$ 
when there was hysteria abroad and the slightest movement brought overwrought shrieks of 'Take cover'. Today people are more cheerful.

It will be a week tomorrow since I last wrote in a rest camp between Molos and Thermopylae. That evening after many hours waiting ready we entrucked and went 5 forward as we thought to do immediate battle. But no: a mile short of the bridge towards Lamia we got out and were given platoon areas to be dug and wired before dawn. What were our boundaries? The Major could not tell us exactly. It was dark and he had not seen them till late evening. Rex protested: his position was in a swamp down to the river. Impossible to dig or wire, even to reconnoitre. We delayed till morning. 10 Sunday morning [//20 April//] I was very tired and my back almost breaking with strain and a chill. The men dug in fast in spite of shortage of tools.

After lunch were ordered to move up on to the mountain side. The men were very gloomy and tired. No news at all, only rumours and much discouragement. The Germans controlled the sky except for a few minutes when three Hurricanes appeared, brought down a bomber, then departed. But the wild cheer they left behind them! I was glad to leave this ground as it seemed to me indefensible even if we had been fully equipped, without tanks and bombers. Somehow we got up a mule track onto the mountain.

My area was a small plateau on the top of the spur. In spite of orders re digging in etc. I was determined they should get some sleep and after feeding them and persuading them to cut sage for their beds we lay down. That was Sunday. Monday up with back much better. Some of the men badly bitten by mosquitoes: vicious woodlice plentiful. The little plateau was wonderfully beautiful: wild mountain flowers grew everywhere among little dwarf oaks and the sage: purples and whites and delicate reds. Behind there were fields of wheat in irregular patterns leading up to the bold bluffs. And behind these was the splendid mountain barrier. Our position commanded a view of the great river flat several miles across by the straight white road which pointed to the heart of Lamia at the foot of its own great range. On the right the sea's arm long as the law, on the left the flat winding into the hills. The river languished in and out like Meander itself. (It was the Spercheus.)

7 tell us ] tellus $\mathbf{1 4}$ controlled the ] controlledthe

14-15 when three Hurricanes appeared, brought down a bomber ] Davin is misremembering. The movements of the RAF can be easily traced, since so few pilots remained. Three Hurricanes brought down a Henschel Hs 126, a reconnaissance plane, near Davin on the 19th of April. ${ }^{259}$ A memory of this event could be wrongly combined with the events of the next day. The surviving Hurricanes in Greece - 20 planes - were grouped together on the 2oth to fight what became known as the Battle of Athens,
17 onto ] o to 30 Spercheus ] Sp ercheus

defending the evacuation ships in the Piraeus. ${ }^{260}$ They shot down six bombers throughout the day, a few by solo pilots and others by groups, but never by only three. Dick Connolly remembered on the 21st of April six Hurricanes shooting down a bomber in his sight: 'The hillside was a sea of tin hats thrown in the air and it echoed to loud cheering'; ${ }^{261}$ Herbert Thomason remembered that 'one Hun plane was shot down by our troops and one by a lone Hurricane, the only allied plane seen by the Bn. in Greece'262 
But there was much to do and nothing to do it with. As our role was a simple anti-infiltration one I did not greatly care. Ration parties were sent off. Tom Morten, Rait his batman and I wandered through the wheat to a spring where we washed and shaved. My tool was very painful and inflamed.

Rations were very short and the men ill-tempered: the position was discouraging: we were apparently going to make a stand and without tanks and planes I could see no reason for official optimism. Akak brought down a bomber but what was one? Still it was better than Olympus in its latter days: but I did not have that old resignation and felt lacklustre and spiritless. The constant arguing of the men irked me.

In the morning Sandy had discovered the Aussies on our flank about to range their mortar on our Bn HQ. They did not

[26]

\title{
25 April contd.
}

suspect there was a NZer within miles. So their infn was even worse than ours. My men went up to cadge cigarettes but had theirs cadged instead. The cigarette shortage was becoming acute: lack of food helped to make everyone worse.

As we were about to start work I was called off to a conference. We were to change position again. 'How is the gallant defender of Lokova?' asked the colonel - half in timid irony but equally I think it was timorous congratulation. As if I had done anything except wait passively for foreseen destruction and when deliverance came by order take it as best we could. It is hard to forgive the major, the colonel, the Brigadier that right flank. Quin knew, I knew and if they listened at all to me they must have known. Not even the pleasure of fulfilled prophecy can compensate me for those poor devils or stop me rehearsing how possibly I might have saved them.

But the new position was certainly stronger: I retaliated ambiguously: 'Getting used to a life of variation, sir.' My exhaustion prevented full anger. We shifted in the evening. I raised more rations, supposed to be for $48 \mathrm{hrs}$ (our dump had been blown up) and we had a slightly illicit feed, making our own tea. It was long after dark when the men went to bed, the tea inspiring them to more than usual loquacity.

The night was much disturbed with reports of Germans below on the plain: but I refused to be excited and on the whole slept well, wrapped in raincoat and bivouac between my sergeant and batman. Tuesday [// 22 April//] we were awakened by an artillery duel. The Germans outranged ours. I did not feel well and cd hardly walk for the pain of J.T. Set the men to clearing tunnels in the undergrowth at the head of our ridge and digging shallow trenches.

10 on our ] onour

3 Rait ] James Owen Rait (1907-1972) Soldier in 23 Battalion; Tom Morten's batman, a labourer from Nelson.

21-23 It is hard... must have known ] Davin sets out its weaknesses to Angus Ross: 'My right flank was open: worse than that, the open ground right of it was (a) higher ground than that held by the right hand post of 3 section (b) it was wooded ground and therefore gave cover to the enemy'263

34 J.T ] John Thomas . (1)

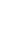

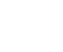


I spent the morning hunting the M.O. talking to Brian Bassett and Tommy Fyfe. The former has well justified my opinion of him, the latter seems nervous and too fussy about bombs. MO found after some reflection decides to evacuate me to ADS. Not serious but since we must either fight or march likely to become so: suppurative 5 balanitis.

Confess I was relieved in a way: did not at all like the situation: chief danger bombers and artillery: though my vitality was low I had a great longing for life. Yet felt like a rat and a deserter. In addition the ailment was so ridiculous. But being ordered to evacuate I managed to spare myself one of those full-dress debates of the conscience, so inconclusive and futile.

Felt tears in my eyes when I left my platoon. Do not know yet if I shall see them again and how many. Probably I was dramatising but the battalion seemed to me doomed. It was as if in going I were taking from them the protection of my personal good fortune.

At the bottom of the hill met Colonel and McGregor in a truck. Apologised to the former but he with a warmth that thickened for the moment the thickness of his blood said: Don't worry about that. The Greeks have ratted and we are withdrawing.

Much relieved lay down in the grass to await McGregor's return with the truck. Mac returned and in the back of his truck listening to the maudlin boasting of two young transport fools sped off to Brigade. Bomb fell suddenly from above but missed us by 20 yards.

At Quarter depot a raid: divebombers: one brought down by Bren.

Then on to ADS. Met Selwyn Clive-Lowe. Half decided to rejoin bn but truck gone when I went out to decide, taking my raincoat. Had feed there and met Ralph Park

\section{4 feed] fe d}

3 ADS ] Advanced Dressing Station.

4-5 suppurative balanitis ] Balanitis is inflammation of the head of the penis; suppurative means that a discharge is occurring. Sandy Thomas heard that Davin had received an insect bite which went septic; this is probably a story to spare his embarassment, rather than a cause. ${ }^{264}$ 15 McGregor ] Arthur Francis Gordon 'Mac' McGregor (1918-1979) A butcher from Invercargill who was 23 Battalion's transport officer. He was captured in November 1941. 17 The Greeks have ratted and we are withdrawing ] Colonel Falconer must have only just been informed; Ross has him being told of the impending Greek capitulation at noon. ${ }^{265}$ Hargest, in contrast, was informed on the twenty-second. ${ }^{266}$

23 Selwyn Clive-Lowe] Selwyn Grahame de Clive Lowe (1904-1977) A New Zealand medical officer. It is not clear how Davin knew him; he came from Auckland and although he had been educated at Otago, he graduated in 1929, well before Davin's time. He was captured on Crete. Released at the end of the war, he emigrated to England and became a consultant anæsthetist. ${ }^{267}$

24 Ralph Park] Ralph George Park (1911-2008) A New Zealand doctor whom Davin had known at Otago. He enlisted in London, where he had been a postgraduate student. During the war, he began to specialise further in an already extant interest: the treatment of skin diseases. He returned from it to work as a dermatologist at Wellington Hospital.

He had edited Critic at Otago and wrote comic verse all his life. His Examples: a thesaurus of allusions, literary, legendary and historic is an autobiography disguised as a thesaurus. Seeing him here, Davin was reminded of 'a quizzical booted jackdaw. ${ }^{268}$ 
now married but otherwise unchanged.

[27]

\section{April contd.}

ADS and MDS evacuated: travelled by ambulance to Levadia: stopped on way by raging Freyberg and forbidden to leave before dark. Amusing scene. Glimpse of Major Hanson. Changed ambulances at Levadia and on to Athens. Very slow progress because stopped at every raid after dawn and men rushed for cover. Felt no fear myself chiefly because there was no danger but partly because crowd-engendered emotion arouses in me its opposite. There was something shameful about the fear of these poor devils, their eyes big and staring, their mouths open and stupid, their reason atrophied. I shall never forget them [// I have. 1979//] crouching round the edge of a quarry like terrified animals when I came towards them to offer a drink from my water bottle. It was unimaginable that a plane should need to waste death on these people paralysed with fear. There was an Australian sergeant in a state little short of hysteria and another NZ private on whom fear had the effect of making him louder and more boastful but none the less fleet. And down the road night and day came a constant stream of fright-crazed Greeks, riding, walking, driving, fleeing as a herd of buffalo might flee, without conscious direction. If the desire to save their lives, I felt, makes people so shameless then I am ashamed of life and certainly it is not worth these indignities. But of course no dive-bomber has so far attacked me.

Wednesday: we reached 26 General Hospital, an LAD English New Zealanders Harold Ward and I: we were given a ward for two, had a shave and a bath and retired to bed, he to sleep and I to read Juan in China: somewhat forced this: he has become too conscious of his tricks: one feels as if one were at a party and I dislike being expected to applaud.

But the luxury of that day. Ineffable.

Late afternoon we were given a few minutes to pack and be evacuated. False alarm and we were sent back to wait till midnight. At three we were awakened, packed on to big Diesel trucks and off about 4.30 through the suburbs of Athens. The air was heavy with flower smell and you could hear the nightingales clear and confident under an immense sky.

And sang within the selfsame wood

1 otherwise] otherwiise $\mathbf{1 3}$ plane] aplane 29 trucks] trucks2

4 MDS ] Main Dressing Station.

6 Major Hanson] Frederick Melrose

Horowhenua 'Bull' Hanson (1895-1979) An engineer from Wellington. Davin knew him because they had been on the same troopship out from England.
22 Harold Ward ] Not identified.

23 Juan in China] A comic novel by Eric Linklater, the sequel to Juan in America. A descendant of Don Juan goes on an amorous adventure into China as the Sino-Japanese war breaks out. 
When bloody Agamemnon cried aloud

And let their liquid siftings fall

To stain the stiff dishonoured shroud.

But it was cold: there was an air of complaint about: these people felt aggrieved, not perhaps without some reason. Yet it seemed as if they might congratulate themselves on getting out so lightly. I suppose they felt here was the opportunity: one was wounded, one could complain and yet by doing so only emphasise one's heroism.

As we drove along an overhanging branch hit me on the nose a fearful crack and gave me too the appearance of the wounded. I by this time had begun to feel rather a fraud. So far I had been carried along more or less on the flood, but now was practically better after prolonged riding in truck and a bath. But it was too late now. There were no trucks going back and I didn't know where the bn was.

Thursday Dawn saw us speeding through Megara. We were dumped in these olive trees. Nancarrow not seen since leaving England and now wounded by bomb in the leg, Ward, an Australian and self. The Australian and I went out foraging, found an abandoned truck, filed open its boxes and found a great store of grub. I got a greatcoat and blanket as well. All day yesterday we ate and slept. Cigarette supply was now refurbished by YMCA. Fairly comfortable night awakening sometimes by the noise of passing convoys. A truck pitched

\section{April contd.}

over a bank and blazed into the night burning a couple of its occupants. I lay and smoked and stared at the enigmatic stars.

Still no news of anything much and impossible to get a cable off to Winnie: might be too soon anyhow. Better get to Egypt first. Greece obviously finished and the Dunkirk I feared already coming to pass. With luck we should get away tonight under cover of dark.

Of the battalion I can learn nothing: perhaps they are covering the withdrawal. But it is no use worrying: and to have leisure is wonderful, even if it be enforced.

The atmosphere is much alleviated today: yesterday it was hatefully hysterical and emotional. Poor devils, most of them are lightly wounded only except one who has a jaw broken in four places but all of them have had frights they will never forget.

And who will reassemble and how our division? And who will recreate poor Greece?

10 flood, but ] flood. but 19 passing ] pas ing

1 bloody Agamemnon ] The appearance of these lines (a misremembered version of lines from Eliot's 'Sweeney Agonistes') in For the Rest of our Lives implies that the poem describes a dream. ${ }^{269}$
14 Nancarrow ] Donald Hewitt Nancarrow (1910-1943) A schoolteacher from Hawera who was an officer in 22 Battalion. He died in Italy. 15 Ward] Not identified. 
Miraculously we are not yet bombed. I have finished de Maupassant's Missie, and St Mawr. Now to the ubiquitous Reader's Digest. All got from the hospital.

And how the devil shall I by that time completely cured face another hospital. That is providing we get away.

\section{6th April Saturday. Thurland Castle.}

Safe or comparatively safe on board. Considerable muddle, waiting etc last night but by 1.30 we were swarming, creeping, crawling and stumbling up rope-ladders. All the officers crowded into the small lounge and after some gossip bedded down on the floor. Slept very well and woke up in fine fettle. Got early shave before queue formed: hungry but couldn't be bothered eating bully. About 0800 severe bombing; some very close misses. Felt quite scared: fear manifested itself in yawns and flippancy. Heavy AkAk fire finally drove bombers off: now $1100 \mathrm{hrs}$ and they have just begun again. Sitting in lounge talking to somewhat homely nurses: have had a talk in German with a Greek nurse who has come along with the others.

Now to see whether we get hit or not.

\section{April Wednesday. Crete.}

We were bombed all day Saturday until we reached the port of Crete: one $1000 \mathrm{lb}$ bomb missed us by ten feet and sprung all the plates. We were held up in harbour till close on midnight. Then sick and wounded disembarked into a Black Hole of a tender, covered over with canvas, having one small hole to admit air and full of noisome petrol stink. It was crammed with men and owing to the number of times we beached in wrong places and slowness of the pace we were almost suffocated by the time we got ashore. Then another long wait, exhausted men lying about everywhere asleep, waiting for transport. When the transport arrived all climbed painfully in, drove about five miles through the cold Cretan night. Another long wait: a few false starts and more waiting. No orders, no information, nothing. Only misery and cold and dumb anger. At last we found the reception tent where my rank disguised by my private's coat I treated an RAMC captain to a withering blast of brigadier standard, made him double the reception service and tell the poor devils what they were waiting for.

1 de Maupassant's ] De Maupas ant's 13 lounge talking] loungetalking 17 Crete] Crrete 22 suffocated] sufficated

19 Black Hole ] A reference to the 'Black Hole of Calcutta', where British prisoners in the Indian mutiny were supposedly confined in such cramped conditions that many died. 28 RAMC] Royal Army Medical Corps. 28 a withering blast of brigadier standard ] Davin expanded on this to Tony Simpson many years later: he 'found there was one little reception tent in this hospital and one very pedantic clerk taking the particulars of everybody and it would have taken almost the duration of the whole subsequent battle to have got them all, and some of these chaps were badly wounded, so I created an enormous stink and said "Get some of your colleagues out of here and have at least four reception people and cut out all of this cock about name, rank and number, you can do that tomorrow."' 270 
At last about 3.30 sank blissfully into a hospital bed: the wrong hut and ward, of course, but at least a bed. Slept most of the morning, bullied my discharge, took leave of Nancarrow, Lewis Ward and the others and began to walk towards the battalion area. Picked up a lift and reached Company at last, grateful to be among normal sensible 5 people again. Rifle battalion a model of efficiency compared w RAMC.

Geoff Cox now Div IO, the job I wanted, but at least it

\section{April contd.}

means there is one good man kicking around Div.

Here we are ready to repel airborne invaders or expected to be ready. May leave soon but if the invasion comes may be pretty awkward to deal with. Short of tucker and supplies generally: but at least there is not much to do.

Camped in an olive grove. Some almond trees as well. From my Platoon HQ (ground sheet, two blankets, two greatcoats, constitute this) can see the Mediterranean, blue as always. Went for a swim yesterday but dangerous for me because shelves steeply.

We overlook also a beautiful valley, ineffably green and threaded by a now river of the clearest and coldest water. Orange groves and lemon line its banks and their hard shiny green contrasts with the weary grey of the olives which look somehow as if the long passage of their centuries had coated them with fine dust. On the other side hills again, curious conical hills, reminiscent of Japanese prints, and on the topmost a white house. Beyond, mountains and the snow. The vines too look fresh and the young grapes are forming but I do not think we shall see their vintage.

It is hard to see why we are staying here, since we need reorganising and reequipping but here we are and at least the weather is as lovely as the land. When I read Greek again I shall read it with fresh pleasure from having seen Greece.

These three days I have not been well: my stomach has at last revolted from eating from old fruit tins, bully beef and M\&V. This morning I felt too sick to get up and when I got up did so to vomit. It is now towards twelve and I have had only a cup of tea and an orange. Part of the morning I spent practising Greek with the Greek children who came selling oranges etc and who here as in every other country are the most intelligent of the population.

My macintosh has returned to me by some devious route and I have reshod with a pair of Australian boots so when my belly is well again I shall be ready for action.

28 vomit. ] vomit,

3 Lewis Ward] Not identified.

6 Geoff Cox now Div IO] This does not seem to have been the case; Cox had been called to Greece to produce a newspaper for the Division, but in the retreat instead assisted the Div IO, Robin Bell in interrogating prisoners.

Hargest asked him to be 5 Brigade's intelligence officer on 5 May, but instead he was ordered to return to the original plan and produce a newspaper. ${ }^{271}$ On Crete he 'was employed as an interrogator and IO on the HQ', but only 'after the attack started., ${ }^{272}$ $27 \mathrm{M} \& \mathrm{~V}]$ Meat and vegetable tinned stew. ${ }^{273}$ 
Tried to cable Winnie but the cable was returned, so will write to her today. Poor kid, if we could get to Egypt I could cable her that money: we haven't been paid for weeks and it is mounting up in my paybook, though some will have to go on fresh gear.

Lots of our mail was burned in the withdrawal, ingoing and outgoing. And there, I expect, goes my only copy of a short story and a poem I sent to Winnie. It's time all 5 staff of the APO were shot.

Chief curse here is nothing to read and no way of getting reaching Kania to get anything.

\section{Saturday 3rd May.}

Still roosting under the olives and the expected attack has not materialised - not that I expected it or expect it. Mayday is past - how different from the old Maydays when the workers of Europe had the turbulent freedom to frighten the fat and sleek. Have to garner all my news from the Kretikos Typos of Khania, and that little. Even then I do not like what little I gather. Have written and cabled to NZ and to Winnie but still no way of sending money.

Yesterday got to Khania by hitchhike: picked up an old Latin schoolbook Lhomard's de Viris Illustribus, Morceaux Choisis Lafontaine, a Greek translation of D'Annunzio, and a curious Greek book purporting to prove pseudoscientifically that all evil springs from women. Also a lexicon. The anti-women book promises to be rather funny. Chania is dusty, grey, provincial, half-evacuated, full of soldiers and flies. The country on the way is attractive and the sea of course is always close at hand.

Slight dysentery among the men: serves them right for ignoring incessant warnings.

Stand-to being observed very strictly and foolishly. Our

[30]

\section{May contd.}

men make a hellish noise when they get up, all with smoker's coughs and of course they are all irrepressible gabblers.

Wind blew hard and unpleasant all day yesterday and today is overcast and threatening rain. If the rain comes we are buggered, having no groundsheet.

Typical answer to any criticism of brigadiers etc. He's a brave man, got such and such a decoration in the last war. As if courage were a sign of intelligence instead of

10 materialised - not ] materialised-not 11 past - ] past-

6 the APO ] Army Post Office.

16 Lhomard] Charles François Lhomond (1727-1794) French priest and grammarian. His De viris illustribus urbis Rome a Romulo ad Augustum is a collection of extracts from Roman histories edited for simplicity, used for teaching Latin in French secondary schools. 17 D’Annunzio ] Gabriele D’Annunzio
(1863-1938) Italian poet and polemicist; he is perhaps best known not for his poetry, but for his flight to deliver propaganda over Vienna in the closing stages of the First World War, his irredentist seizure of Fiume and declaration of an independent state, and his development of the pageantry of Facism later adopted by Mussolini. 
being more likely to the contrary. And in any case bravery is the most commonplace of all the virtues. Brave men are as common as mud round here. [// What a lot I had still to learn. DMD 1979.)]

Rex has made a chess set out of bamboo. Discovered a treachery of the Maj's which 5 confirms a suspicion. Claims to have been 'disappointed with Dan' for letting Hun behind right flank. This after I had predicted it weeks before and complained to him, the Colonel and even the Brigadier that it was impossible to prevent without more men. And they agreed and did nothing. This after I had been given a position [from] which nobody in the battalion expected me or my platoon to come out alive and accepted it without a murmur! And Rex now learns that the B. rejected on his behalf and without consulting him a W.O. offer of instructor's job in AT staff. These revelations of pettiness and folly come like periodical reminders of the sort of people controlling one's destiny. Certainly a man needs luck to escape such jeopardisers.

Dusty Answer.

We are the prisoners of infinity

And God's hand the sky is closed upon us.

Though dizzied eyes should scan the tented night

And dally with the stars, they cannot pierce

The unillumed beyond, the world behind

Our world, where blindness thwarts our quest and sight.

Our finite antenna darkly fumbles

In eternal dark. Though men with minute

Scrutiny have conned atom-horizons

Within the microcosm, new worlds have thrown

Fresh gages. Each point presents its jungle

Of perplexities. Blunt touch can finger

The tangible's clear face but never tell

The seething life beneath; [(]nor taking thought

Can we perceive our souls.[]] What thought so strong

To outside tireless time and find the end

Of endlessness. Our minds pace caged

In confines of the finite, our dreams are sick

For fields beyond the known or knowable;

Nor taking thought can we perceive our souls,

Discerning only a vastness as of shifting sands

Unchartable. One escape remains:

In death annihilate the query.

13 Certainly ] Certa nly 15 infinity ] infi nity

2-3 What a lot I had still to learn.] Davin's updated thinking can be seen in the declaration in For the Rest of Our Lives that 'Courage may be common, but it's not commonplace.'274
10 B. ] An ambiguous initial: brigadier, battalion, or bastard.

11 W.O.] War Office.

11 AT ] Anti-tank. 


\section{Monday 5th May.}

Shifted position late Saturday afternoon closer to Mallame drome. Hard going in Australian boots, too small. Now settled in another olive grove, with nice beds scooped out among the barley. The crop I am afraid is ruined but in these days of destruction that is a small trifle. Deep gully running right through the position affords fine shelter. Otherwise life goes on unchanged: water is closer and the land is rich and more attractive. The birds sing more sweetly than I have ever heard birds sing but the harsh triple cry of the peacocks is more persistent than the nightingale's song.

Freyberg was round yesterday to congratulate us on our withdrawal and explain to us our new role. He confidently expects invasion but as OC Crete probably overrates its importance. Spoke very sensibly, the brigadier behind him fortunately compelled to [31]

\section{May contd.}

be silent.

Just missed a job with a Gk battalion: unfortunately they wanted a captain or major. Max Smith got it. I would have jumped at it. My luck seems to stop short at life saving. [(I little knew. DMD 1979.)]

Had a good bath in the creek yesterday afternoon.

This morning interrupted in game of chess on Rex's improvised bamboo set to go on a surprise stunt, shortly over fortunately. News of the 21st: one man rowed across: 4 days, slice of bread and meat per day. 8 officers touched at almost every island in

16 Max Smith ] Harold Maxwell 'Max' Smith (1906-1980) A Dunedin journalist (for the Evening Star) who was second-in-command of D Company.

16 My luck seems to stop short at life saving. ] i.e., my luck stops short at saving my life. 17 [(I little knew. DMD 1979.)] ] Smith was posted to 6 Greek Regiment. They lacked ammunition or training, and when attacked fell apart almost immediately. 'Some no doubt made their way east to 2 Greek Regiment or into the hills towards 8 Greek Regiment. Others reached Galatas or 19 Battalion and were to reappear. But as a unit 6 Greek Regiment ceased to exist. ${ }^{, 275}$ Reading between the lines of Davin's account of this in Crete and Kippenberger's in Infantry Brigadier, Smith's failure to rally them and subsequent retreat to 19 Battalion put great pressure on the rest of 10 Brigade until a party was rallied at Galatas by Brian Bassett and Michael Forrester, an English officer. A whiff of discredit attached to Smith, and his military career went little further. Davin's diary, noting the survivors of the Crete campaign, has the entry 'Max Smith (discredited)'. Kippenberger, in his account of the Greeks' actions, does not deign to mention Smith.

20 News of the 21st ] The 21st Battalion had been surrounded in Greece. 
the Aegean, were at sea 12 days and finally got here. Colonel Mackie, Captain Dutton, Padre Shiely all safe. Glad about Mackie: for a colonel he is intelligent and courteous.

Still no beer: life is boringly healthy. But it is hard for the men to be cooped up with nothing to do but play cards all day. Their education has left them without 5 internal resources. Our civilisation takes from the average man more than it gives. They have discovered there is a brothel in Chania somewhere so they'll all be off on some pretext before long. Two drunk yesterday. Tough guy Congo Smith was AWL and at the whorehouse but the only proof I have I got accidentally from his friend so I can't charge him. Would like to as he lied shamelessly - very rare thing among these fellows.

V. disturbed night last night. Two drunks pinched a Greek truck, broke down near here and escaped and I have to straighten the situation out.

Costello is to go before a selection board for a commission today: he got out with the last party. So they're learning sense at last. He was apparently invaluable and the chief 5 instrument of their escape. I can imagine the ludicrously solemn military commission conferring with condescension the opportunity of imparting some intelligence to a higher sphere of action on him. I wish Cox and he and I could get jobs together as team-mates.

Expect we will stay here a week or two, be relieved, reorganise in Egypt: thence Libya or Iraq. Who knows, and at this distance who cares?

Before I forget the incident must remark how Peckham and Edwards in the thick of the Olympus scrap went down into Lokova, covered by Dittmer's Bren, and cooked a feed of eggs.

16 intelligence ] inteeigence 21 Edwards in ] Edwardsin

1 Colonel Mackie] Neil Lloyd 'Polly' Macky (1891-1981) Colonel commanding 21 Battalion in Greece.

Most of his battalion was captured there, and he was relieved of command after his escape and returned to New Zealand. James McNeish strongly defends him in The Sixth Man, but Kippenberger's verdict is perhaps more convincing: he notes that an entire battalion ${ }^{276}$ was ordered by Macky to take to the hills in individual parties, destroying it as a fighting unit. And yet it was faced by one-and-a-half platoons of infantry and four active tanks, and had taken only four casualties. He calls this 'a classic example of bad dispositions and a bad order $[\ldots]$ causing a fiasco. ${ }^{, 277}$

After the war Macky became a senior partner in the law firm Russell McVeagh. 1 Captain Dutton ] Garth Ainsworth Dutton (1910-1990) 21 Battalion's Adjutant, a teacher from Katikati. He was taken prisoner in the desert in November.

6 a brothel in Chania somewhere ] According to one provost sergeant's report, there were actually now thirty-seven, 'thirty-six of them owner-driven. ${ }^{278}$ The price was ' 50 drachmas a time, about $1 / 9^{, 279}$ when a private's pay without allowances was $7 / 6 .^{280}$ 17-18 I wish Cox and he and I could get jobs together as team-mates.] James McNeish quotes Davin as making this plea in hospital. ${ }^{281}$ 21 Edwards ] William Anzac Edwards (1920-1989) A private in Davin's platoon, a bushman from Hokitika. 
Sergeant Mulherne was shot through the chest and head as he was about to throw a grenade. He fell back in the holes, his hand slowly opening. Brooks, Herbie's batman, saw the spring fly, picked up the grenade and threw it at the two Germans, killing them both. Mulhearne said as he died: The poor wife and kids.

One of Bond's men, unable to swing his Bren fast enough on the parapet to deal with the swarming attackers, stood up with the gun at his hip and beat the attack off. Luckily the Huns seem to be very bad shots.

Austrians taken at the northern pass and asked why they fought said: With the Germans behind you and in front what else can we do?

I think I saw about 6 of our planes in Greece. Baldwin, Baldwin!

Dysentery is becoming milder.

Have had excellent opportunities of studying the genesis of rumour lately. Always most rife when there is no official news, always in my experience favourable to us. A rumour can traverse a deployed battalion in less than an hour, multiplying itself and

1 Sergeant Mulherne] Michael Edwin 'Mick' Mulhern (1904-1959) 7 Platoon sergeant, a railway fireman from Christchurch. 2 Brooks ] John Edward 'Shorty' Brook (1918-1942) Private in 7 Platoon, a labourer from Fairlie. After being Herbie Black's batman he was a bootmaker, then Peter Norris's batman. Accidentally killed by an Allied mine, 24 June 1942.

2 Herbie] Herbert Charles 'Herbie' Black (1917-1943) Commander of 7 Platoon, A Company; a warehouseman from Christchurch. He was killed at Takrouna. 4 as he died ] Mulhern did not actually die, but was wounded and left for dead before being taken as a prisoner of war. ${ }^{282}$ Brooks did not pick up a grenade. 'I asked someone for a grenade and told the man who had seen the movement to let them have it. I forget who the man was. He pulled out the pin, but for some reason or other he could not unclasp his hand from it. I crawled along, took the grenade from him, and threw it. ${ }^{283}$ However, the incident (and mistake) made it into Brook's citation for the Military Medal in the London Gazette of 31 October 1941: 'At Kokkinopolos, Greece, on 17 April 1941 Private Brook was a member of the rearguard above the village. They were attacked by enemy light machine guns and their Sergeant was wounded. While throwing a hand-grenade the Sergeant was again hit and fatally injured but Private Brook seized the grenade and threw it, killing two of the enemy and preventing them entering the position.' Mulhern was wounded by a rifle, not light machine guns. Bassett tells an even more highly-coloured version of the story in which Mulhern is shot when he tries to report to a figure 'in our battledress with our New Zealand and Brigade patches. ${ }^{284}$ 4 The poor wife and kids.] A second letter concludes: 'I might mention that my wife received a letter from Mr Black, after my 'death', with Shorty Brooks' account of how he had held my hand when I died ${ }^{285}$ This was very much not the case.

7 Luckily the Huns seem to be very bad shots. ] Len Diamond, a private in Sandy Thomas's platoon, made the same point reporting on the Olympus fight in the New Zealand Free Lance ${ }^{286}$ Bassett, typically, puts it more vividly: 'They can't shoot for nuts, but these mountain troops can certainly get about. ${ }^{, 287}$

10 Baldwin, Baldwin!] Stanley Baldwin was prime minister of Great Britain multiple times between the wars. (There is a bitter reference to him on page 139 of For the Rest of Our Lives.) In 1932, he declared 'that the bomber will always get through'; ${ }^{288}$ this was used as a justification to focus on building deterrent bombers rather than the fighter aircraft which might have been of use in Greece. Meanwhile, Winston Churchill attacked him in any case for not expanding the RAF with sufficient speed. Davin is probably criticising one or both policies. 
splitting up into versions as it goes like an amoeba. Simple example: so many thousand troops have landed at Cyrenaica; developed, 30,00o Canadians have captured Salonika. Simple: a raid has been made on the French coast. Developed: British forces are within 25 miles of Paris.

\section{May contd.}

Day becoming overcast as I write with a threat of rain. If it rains we are ditched, having only a few groundsheets.

Thinking much of the old days now: the first and second books I ever read, when I was four, The Lone Star Ranger and The Rainbow Trail «by» Zane Grey. Terry Maunsell has been much in my mind too: his attempted suicide, his picaresque life in the Otago commonrooms, the attempted murder, the birth etc.

\section{Thursday 8th May.}

Sitting in a chair that looks as if it walked out of that picture of Van Gogh's, a restless quadruped. Somebody, in fact, borrowed it from the Greek orange-drink sellers: it is stand-to and the men stand around in their compulsory grouping, enjoying the sort of gossip that takes place on a Sunday after Church i.e. there would be no gossip unless there were church and stand-to and church resemble each other in that they are both based on a sort of religious compulsion. To the military mind stand-to has all the sanctity of a liturgy: and form dominates meaning.

The real horror of stand-to of course does not arise until morning. At 5.15 the patrol wakes sgt and self and we must have the men up and armed from 5.30 till 6.15. It is amusing to see them from 6 on squatting above their blankets like a lot of rabbits or prairie dogs, ready to scurry. As soon as 'stand-down' goes they dive into their bed,

19 stand-to has ] stand-tohas

10 Zane Grey] Pearl Zane Grey (1872-1939) American author of (very) popular Westerns. He was important in developing game fishing in the Bay of Islands. The Lone Star Ranger and The Rainbow Trail were both published in 1915; the first is the story of an outlaw who beomes a Texas Ranger for a pardon; the second, sequel to another book, is a saga critical of both Mormons and missionaries.

10 Terry Maunsell] Terence Arthur Mears 'Terry' Maunsell (1909-1940) A doctor who trained at Otago in Davin's time; he drowned when H.M.S Glorious was sunk in 1940. An article probably by Davin in Men Lonely suggests that he knew this: 'She asks for Terry - drowned off Narvik.' 289
11-12 his attempted suicide, his picaresque life in the Otago commonrooms, the attempted murder, the birth etc. ] The details of all of this remain obscure; the attempted murder occurred on November 14, 1932. Maunsell was living in a boarding house with two girls; one, Ruth Eleanor Corlet, was attacked at night with a hammer by Thomas Polson, an acquaintance of the other. Maunsell was woken by Corlet and saw Polson before letting him go. He was a main witness at the trial, 'in which a good deal of public interest has been aroused'. ${ }^{290}$

14 that picture of Van Gogh's ] Probably the painting known as 'Van Gogh's Chair' (1888), which Davin might have seen in the National Gallery. 
cigarettes are lit and within ten minutes finished. In a quarter of an hour the chorus of smoker's coughs which during stand-to advertise our presence for miles is still and the camp is quiet.

But at 7.15 once again pandemonium. Breakfast is shared out in an atmosphere of fell suspicion and each man like a hen with a precious morsel hustles off to his tree. Hunger allayed, cigarettes are alight again and faces. The sun is up, I shed my B.D. trousers and appear in shorts. The day has begun.

The morning goes in water-parties, ration parties and otherwise leisure. All day the men play cards, with naive cunning I am told but I am not a card-player and do not know. Lunch except for a bathing party down to the Mediterranean the afternoon goes in similar fashion. Tea at 5.15 - stew or bully beef, rice, bread, butter and jam, appalling but the most substantial meal of the day. Nothing then till 7 when a sort of semi-stand-to follows till 7.45 when an hour's full dress performance begins.

We have lost most of our blankets, groundsheets, greatcoats etc. Sgt Dutton, Ginger and self sleep three-abed. I often lie awake smoking but their wild chorus of snoring soon forces me to take cover in sleep.

Which reminds me: our escape, at which I was not present, from Molos was less audible to the enemy because of the loud symphony of frogs in the river swamp. Thousands and thousands of frogs, having a variety of notes and pitch which makes the NZ frog a provincial performer. Or rather not so much a symphony as a vast orchestra forever tuning up and prevented by some malignant fate from ever being able to begin.

In this olive grove the barley is now trampled low and lies a weary gold upon the yellow clay. From the foot of this tree one can see through vistas of olives which though not in mensurate distance seem to stretch not merely in space but in time's own dimension back through an infinite past. What a picture it could be that particular subtle colour of the olive leaf, grey and green and neither, time's colour if time had a colour; soldiers bivouacked in the barley in attitudes and posture as old as soldiery and the long low slanting lights of evening or morning brightening the spaces and darkening the tree boles. I think of forgotten pictures seen long

\section{May contd.}

ago on forgotten walls, of picaresque Breughels, and besides something that pictures never held, the old magic of a long and pagan past. There has been so little change and so much turmoil.

Seeing how few trees there are in Greece one knows how it was that the Athenians so dependent on the sea had to go far and somewhere have resort to land to find their timber. Dendra and its frequency are now explained.

26-27 grey and green and neither, time's colour if time had a colour; soldiers bivouacked ] This passage reappears in Davin's poem 'Night Before Battle', which appeared in the June 1943 number of New
Writing: 'Grey and green the olives, darkening the dusk[...] Bivouacked the soldiery, sprawling and sad.' 37 Dendra ] Form of $\delta \varepsilon \dot{\varepsilon} \delta \rho \alpha$ : tree. 
And yet oddly enough this is now a very Christian country: from what I have seen the only Christian country where the Christian virtues are found in practice as well as in preaching: at least I seem to feel religion as saturated into everything the people do. Though perhaps these simple virtues they have kept from ancient times. The Greeks I have seen come very close to what imagine the ancient Greek to have been.

Read Mary Webb's Gone to Earth. Know what she means and sympathise with her but she runs too close to bathos. An awful lesson in my own faults as a writer which makes me uneasy. Too lush but[and] in spite of Buchan she does write too much 'poetic prose'.

The flies are the chief torment in our Eden. Tomorrow early I go towards sunrise and Khania. If I can talk the money out of Base Pay I will cable $£ 20$ to Winnie.

Wild as the ghost of a lost ardour the wind

Comes cold,

Piercing to grief pent memory in heart's

Deep hold.

\section{Friday 9th May.}

Stand-to again and like last night's the sky is overcast and threatening rain. If it rains we are done. Tonight Ginger has fallen to the dysentery.

Much tormented these days by a Greek pilot who flies constantly over our heads very low to exchange a wave of the hand with his girl in the nearby village.

Three chaps from D Coy have asked me to defend them in CM - charges drunkenness, breaking and entering etc. Apparently pleading not guilty though obviously guilty. Think these men deserve more than they'll get and yet must try and get them less than they deserve.

11 talk] t alk

6 Mary Webb ] Mary Webb (1881-1927) Shropshire novelist, a bestseller after her death. Gone to Earth is the story of a very beautiful girl who throws herself (and her pet fox) down a mineshaft to escape the local squire. There is, perhaps, an ambience to it reminiscent of Cold Comfort Farm.

8 Buchan ] John Buchan (1875-1940) Author of The Thirty-Nine Steps. No use of the phrase 'poetic prose' by him has been found, but at one point he makes a passionate argument against what is effectively poetic prose, describing how he turns 'with comfort from the freakish, stuttering, self-conscious rigmarole of too many modern litterateurs to the clean-cut, efficient prose of a newspaper article. $^{291}$

12 Wild as the ghost of a lost ardour the wind ] This stanza reappears, slightly edited, as the final stanza of Davin's poem 'Night Before Battle'.

19-20 a Greek pilot who flies constantly over our heads very low to exchange a wave of the hand with his girl in the nearby village ] This is probably an error on Davin's part. There were very few planes on Crete, all of which were in English squadrons. However, one RAF pilot was a New Zealander from Christchurch, 'Jerry' Westenra; he may have been waving to a friend in the Div. 
Went to Khania today: impossible to cable money from the island. Pay recommends writing to Base Pay in Egypt. A good idea and will write tomorrow.

Bought Pascal's Lettres Provinciales and a book of Anatole France's Found quite a number who talked French: so much so that I caught myself saying garcon in a restaurant, as if it were Montparnasse again. Bought two bottles of mavrodaphne: excellent wine: $35 \mathrm{dr}$. No adventures but more interesting than before: more people about, more shops. Looking for Greek coloured blanket to bring home for Winnie but haven't found one yet. Though the town is drab Winnie would have loved to poke around the old shops. And she would have liked the Street of the Ten Corners.

There is a mail coming up to Company tonight but I have not the courage to hope for a letter. Bought a couple of Cretan newspapers today but no news worth reading in them.

Three-quarters of a hour still before one can smoke: just as well perhaps as I have a bad headache and am just recovering from a black mood.

\section{Sat. 1oth May.}

Stand to again. Great day today: in the first mail two letters from NZ, bank statement from Oxford (£2-6 OD). But no letter from Winnie. And then later in the morning a letter from Winnie posted 11th Feb. And there were some charming photos of Winnie and Anna.

\section{May contd.}

Months old this news, but how good to get and how good to taste the individual Winnie in her style, after the dull French dogs I have been reading in Morceaux Choisis. When will we integrate one of our little worlds again? I notice that in one's first delight there is a temptation to read the letters and show the photos to the first comer. The impulse is to share: but these pleasures are private to a private world, and commonsense says that one can only share that particular thrill with the subject.

Today simmering with inner satisfaction went down in the renewed sunlight to bathe in the creek. There as Rex and Gordon Cunningham and I sat gossiping on the bank we saw two frogs making love, a thing I have never seen before. It was highly ritualised and rather moving: not grotesque as one might expect. All of us sat interested and all felt the spring is everywhere but we have on this island no mates to love. The frogs were very pretty, glistening with gold and as they croaked to each other their

11 newspapers ] newspapwrs $\mathbf{1 3}$ Three-quarters ] Threequarters $\mathbf{2 4}$ will we ] willwe

3 Pascal's Lettres Provinciales and a book of Anatole France's ] The book of France's was Sur La Pierre Blanche. 'I must read very slowly for fear of finishing them too soon. ${ }^{, 292}$ 5 mavrodaphne] A dark, sweet Grecian wine.
9 the Street of the Ten Corners ] Not identified; Canea was almost entirely destroyed by bombing and rebuilt after the war. ${ }^{293}$ 'The streets, except for a few main thoroughfares,' were 'narrow and ill-connected'. ${ }^{294}$ 
cheeks filled out like small balloons to such a transparency that one waited for them to burst.

Afterwards, having in some inexplicable manner achieved some lice, I stripped, deloused and shaved - tonsus Apollo! Then I walked up over the terraces in the olive 5 groves and lying in the shade read once again Winnie's letter and lingered over the photos.

Tragic prospect: we have to endure a syllabus of training from Monday. How it will be got through I don't know. Goodbye to the long hours of sunlit leisure. At least the forthcoming $\mathrm{CM}$ will get me out of the dreariness of dull repetition of lessons many of which the men from experience now are certain are nonsense. Still we shall survive and each day provides its own evasions.

Last night Sgt Dutton and Ginger went up to outhouse to sleep. I stayed here in greatcoat till at $3.30 \mathrm{am}$. the rain coming heavily and a thunderstorm drove me to join them.

Have been reading Anatole France Sur la Pierre Blanche. Distinguished and fine as ever. Reminds me a lot of Bertrand Russell.

Wrote to Les Greig tonight to try and get money sent to for Winnie.

Jeffries brought along large piece of [Xmas]-cake: delicious: no such cakes outside NZ. Our criminal post comes home sometimes.

Peckham now back to full corporal: hope I'm right.

Trying to find a coloured blanket ultimately for Winnie.

\section{Sunday 11th May.}

Letter from Jack Gonley this morning. Also invitation card from Hellenic Society! Been pretty gloomy today: nothing left of the letter pleasure but the longing for Winnie and Anna and the peace to do the things I want to do.

Sgt Dutton building a bivouac of bamboo and the groundsheets wh arrived today. He is one of those who insist on doing the whole of such a job and answer criticism with the charge of laziness.

\section{Tuesday 13th May.}

Wrote to Winnie on Sunday, NZ yesterday. Last night Brian Bassett arrived with news: Falconer is going to a mixed brigade and Brian with him. Leckie becomes $\mathrm{CO}$,

\footnotetext{
4 tonsus Apollo!] Plutarch says that as part of an initiation rite boys would offer up their hair to Apollo at Delphi. ${ }^{295}$

18 Jeffries ] Ulric James Jeffries (1907-1985)

Private in 23 Battalion, a farm hand from

Marlborough.

23 Jack Gonley] John Joseph 'Jack' Gonley (1908-1986) Winnie's older brother.

23 Hellenic Society] Probably an invitation from the Society for the Promotion of Hellenic
}

Studies, based in London, to a function in England. This would have been given as a result of his Oxford studies and had nothing to do with his presence in Crete. There was an Anglo-Anzac Hellenic Association in Cairo, but as far as can be dated, this was formed after the loss of Crete.

31 mixed brigade ] 10 Brigade, a new brigade formed from disparate units. Falconer almost 
I am to be IO from lunchtime today. Athlone Castle bears fruit at last, just as I had resigned myself to being submerged for good. Consternation in the Company: the Major's feud will rebegin: has begun with Leckie's discourtesy in going direct to me and not to OC Coy. Rex is sorry to see me go as we get along pretty well. Sandy has his own troubles: rows through his flying without permission and a chronic dispute with OC. Has played his hand badly ever since Olympus. Tom I think is also sorry to see me go as we were good colleagues. I am not sorry to go

[35]

\section{May contd.}

because the job will be more interesting and I was becoming bored with petty affairs. Though there will be plenty of petty domestic troubles at HQ and I will need consummate tact to steer by. Of course the new brigade may fall through any time but at least I have a leg in. Bassett very helpful with hints and information. Learnt a bit this morning: scene at Bn HQ Olympus, Sandy's recalcitrance and its reaction hitherto unsuspected on my position at Olympus.

New flap this morning. Attack expected in 4 days. Big raid at Suda Bay. Still don't expect invasion but always possible. Latest rumour of 6 months stay.

May get a chance to learn modern Greek speaking from interpreter.

At last escaped from the grinding boredom of the training syllabus. New job to make myself indispensable somehow or other but must proceed with great caution.

3 direct $]$ diect

immediately handed over command to a rising star, Howard Kippenberger and took command of 4 Brigade briefly before returning to Egypt when Inglis arrived from Egypt to relieve him. Kippenberger kept Bassett on, appointing him as his Brigade Major. 2-4 the Major's feud... to OC Coy ] Continued disputes between Leckie and Thomason ('OC Coy'), the next most senior officer in the battalion; the battalion's promotions had a tendency to be temporary and changeable rather than substantive, encouraging persistent rivalry. Kippenberger also makes an oblique reference to 'some absurd provincial jealousies [that] had not yet died out' in 23 Battalion, which may imply something more personal to the feud. ${ }^{296}$ Bassett similarly describes how his promotion to Captain, supposedly on Leckie's recommendation, meant that 'Like Tom Morten, I get lots of good-natured bantering from the others on my social crawling to the Southland set, ${ }^{297}$ while Wally Gibbons remembered that 'provincialism was particularly rife in $23 \mathrm{Bn}$ and North Islanders looked on as "second rate New Zealanders" and that "the rivalry between Leckie and Andrew was filtered down to the lowest levels." ${ }^{298}$ Thomason was a friend of Andrew. 5 his flying without permission] Thomas recalls that he persuaded the diminished RAF on the island to take him up for a flight to investigate the lay of the land, and was reprimanded for risking one of very few remaining aircraft on a task not strictly necessary. ${ }^{299}$ 
Fletcher still A.W.L. Yesterday somebody hit an innkeeper in the eye with an egg. Finnerty fell drunk $12 \mathrm{ft}$ on his head but survived. Gageye had an outbreak, is up for C.M. and wants me to defend him.

So ends Volume II. Must give this to Munir to keep if we go back to Egypt. No way 5 of sending it safely home.

\section{DMD's DIARY NOTEBOOK C.}

\section{[// 3 June $1941 / /]$}

Sitting up in bed in Heluoan Hospital, transferring addresses from last diary, and a few entries from loose papers. .30 and reasonably cool. Just bathed and shaved. Only poss time of day to write now. Bad dreams and broken sleep last night. Among other things dreamt still on Crete w Shirley Temple: fully cognisant that one of the curses of the age was in my power. Should I kill her or leave her to the Germans? Fortunately she turned into a cake of chocolate and I solved the simplified problem by eating her.

\section{Saturday 17 th May.}

Machinegunned and bombed night of 15th after stand-down. Thought attack on and slept in boots. No blanket and damnably cold. Following morning same performance at breakfast time. Bn HQ v unprotected: during raid felt like naked man in Piccadilly during a hailstorm: no decent shelter anywhere. Afternoon shifted HQ behind Daskaliana into deep gully where I am now sitting enjoying my afternoon smoke. It is 6.45 p.m. Work so far chiefly route reconnoitring. Tiring. Walking all day in various directions but country interesting. Few raids since Tuesday but not impressive. Far less danger here.

Major Fyfe came back yesterday from Suda Bay. In the evening German attack reported v. probable for today or the 19th. Am sceptical, in spite of circumstantial detail.

12 Shirley] Shorley 216.45 p.m.] 6.45 p.m..

1 Fletcher ] Frederick Fletcher (1910-1980) Private in Davin's platoon. He enlisted from the P.W.D in Inangahua; by trade, however, he was a wire-mattress weaver from Westport. $\mathrm{He}$ evidently returned, then was sent to 5 Inf Bde Field Punishment Centre on the 15 May

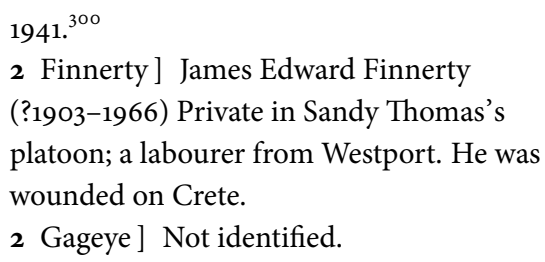


Major Fyfe lent me a blanket last night. Ginger had dug me a hole in the bank and I retired in anticipation of a fine sleep. Blanket was full of fleas. Caught one this morning and just missed one now.

Dick Orbell now a captain. Maj Leckie acting-Colonel. Wants more than that: no pay increase. Gone off to see Stephen Allen tonight. This latter a snob.

Col Falconer when he saw his men straggling about the roads: 'That's your Labour Govt. for you'. As if he hadn't had his chance to impose discipline: the idea being that the govt has made the workers so cocky that they haven't the instilled sense of hierarchy. The irony of it: that these people are all crypto-fascists fighting fascism. And hardly one of them has a head that would hold an abstract idea without cracking.

Rudolf Hess landed in Scotland. All 'soothsayers, crystal-gazers, palmists and fortune-tellers' are forbidden the German stage.

'Crete News' in English prob edited by Geoff Cox.

Germans using French air bases in Syria. British bombed there yesterday.

Big mail in two days ago. Nothing fr W or NZ. A bill and a letter fr the Harcourts in India.

[37]

\section{May contd.}

Scoular, Caldwell, Simmonds, Moodie (Nance's brother) posted missing.

That was my last entry before the blitz. On the 19th May nothing happened either beyond the usual bombing courtesies, slightly intensified. Bought some beer and had a few drinks w Dick Orbell. Very pleased because predictions of no attack apparently

9 it: that ] it: that: 13 'Crete News'] ' Crete News'

5 Stephen Allen ] Stephen Shepherd Allen (1882-1964) Military Secretary; a former administrator of Western Samoa.

6-7 'That's your Labour Govt. for you'] The phrase is used by the Colonel the night the Div Cav tried to burn the NAAFI canteen down (see entry for 18 March 1941, p. 63) in For the Rest of Our Lives. ${ }^{301}$

11 Rudolf Hess ] Rudolf Walter Heß (1894-1971) Deputy Führer, until, in 1941, he flew to Scotland in an apparent attempt to negotiate peace.

13 'Crete News' in English prob edited by Geoff Cox ] It was. Davin devoted an appendix to it in his history. '[T]he troops on Crete were cut off from all the regular sources of information about events in the outer world [...] General Freyberg quickly realised that rumours, defeatist or wildly optimistic, were rife and dangerous. The best counter-attack, he decided, was a troops' newspaper. ${ }^{302}$ 14 Germans using French air bases in Syria. British bombed there yesterday. ] Surprisingly, not an example of the rumours mentioned. German and Italian aircraft were using Vichy French bases in Syria en route to Iraq for use in the Anglo-Iraqi war. ${ }^{303}$

15 Harcourts ] Robert Maurice Harcourt (1916-After 1997) At Balliol with Davin; he had gone with his wife Kate to join the Indian Civil Service (not, pace Ovenden, to become a teacher. $)^{304305}$

19 Scoular ] James Crawford Scoular (1918-1970) Officer in 1 Reinforcements, a Dunedin clerk. He and Simmonds trained with 23 Battalion, but were not part of it. They were captured on Crete when evacuation plans broke down.

19 Simmonds] Kenneth Simmonds (1907-1976) A Dunedin factory manager. 
correct. Morning of 2oth stand-to and breakfast as usual: the latter interrupted by raid. Finished my tea and retired to hole in gully bank until raid should end. A.P. bombs fell closer than usual, raid heavier. Also seemed to be longer. Shortly lookout from hill reported gliders over the drome. Very irritated at this departure from routine. Thought 5 Jerry had more respect for schedule: and now he falsifies my prophecies and puts the intelligence report more or less in the right. Clearly the attack had come.

Went off to get Intelligence Section to Lookout Hill and send runner to Battle HQ over near mortars. No section to be found except Foster jellied by fright in a hole. MG of increasing tempo. Very excited and rather frightened. Found Ron Stewart contemplative in gully. Went out of the gully to look for Ginger. Unpleasantly exposed gallop across open to his slit trench. No Ginger. Watched planes circling overhead machinegunning anything and everything. Masters of the local air. Ginger appears. Had been down having a shave. Got him back to the gully and sent him off to Battle HQ. Returned to Foster. Quite useless but cd see something wd have to be done with 15 him. No sign of Young, my best man. Made Foster get his gear and come with me. Made for Lookout Hill. Very difficult climb, exposed. Poor Foster. Half way up planes so thick decided to have a crap while waiting for them to clear. Then sick of waiting got going again, found a path and brought on Foster. Heavy troop carriers now prowling 3 be longer ] belonger

2 A.P.] anti-personnel.

5-6 the intelligence report] This is an interesting revelation. There has been controversy over to what extent Freyberg was constrained in making use of his knowledge of enemy plans derived from ULTRA, the decryption of German wireless traffic. A report derived from these decrypts, 'BGS Appreciation - German Plan for Attack on Crete' had some distribution (45 copies), and must be what Davin is referring to, since it was the only prediction of dates of attack. ${ }^{306}$ That knowledge filtered down as far as Davin, a very junior officer, strongly suggests that Freyberg's constraint was limited.

7 to get Intelligence Section to Lookout Hill ] Lookout Hill was sited 'about 100 yards south-east of Battalion Headquarters', ${ }^{307}$ above the battalion's few Vickers guns and mortars on the slope leading up to it. (The battalion war diary, by contrast, says that 'the intelligence section had an O.P. [observation post] at Battle HQ in in HQ Coy. No. 1 Area where Richards and McGregor were situated. ${ }^{308}$ The divergence is very minor when it is remembered that Richards was in command of the mortars.)
8 Foster] Rayfield Charles Foster (1915-1973) Private in Intelligence section, 23 Battalion. Before the war he worked in the Masonic Hotel, Nelson.

10 contemplative in gully] Given the repeated references to this gully in Davin's narrative, it is worth providing some description of it. Ron Stewart's medical section was established 'in a dry watercourse close to $23 \mathrm{Bn}$ HQ on a road leading south from the road Canea-Maleme, the road junction being some half mile [sic] east of Maleme village. The stretcher bearer section constructed some dugouts in the banks of this watercourse and dug a ledge in the dry bank to serve as a dressing table. The site was well protected except from a direct hit and well covered by olive trees. ${ }^{309}$

15 Young] Robert Carmichael 'Bob' Young (1902-1971) A farmer from Marlborough who was a private in the Intelligence Section, 23 Battalion. He later became an intelligence officer. Bassett describes him as 'the middle-aged boy with the pipe. He was the unit hero in Crete' serving as an intelligence sergeant after Davin was wounded and his sergeant, Jim Bevin, was evacuated with dysentery. ${ }^{310}$ 
about. Spotted us and MGd us but we lay flat and were not hit. Got to the top where found some of the I Section driven from the lookout point to a position of poorer vantage but better cover. Imposs to get back to it. Parachutes had been coming down at Malleme. Sent runner to BN HQ. We smoked a lot and without much effort I was able to be casual and they began to rally a bit. Got the section disposed for all round defence and sent message for HQ Coy HQ to do likewise.

Parachutists descended on the other side of Red Hill. Also on Battle HQ and mortar positions. Reported. Ginger returned: cut off from objective by parachutists and had to come back.

Three troop-carriers came over very low and distributed their gifts of bullets at a great crescendo. Then hey presto out come the parachutists to the left front. Terrific uproar of small arms fire from our men, like the crackle of a great bush fire. My men firing with great gusto.

[38]

\section{May contd. (and up to 3 June)}

Watched for a while: extraordinary spectacle: strange, odd, with the irrelevancy and yet the appropriateness of events in a dream. Like a futurist Wellsian film, rather irritating to me because I don't like that type of fantasy. It is an impertinence to probe too far into the future. Suffice for the day. As if we haven't enough to put up with already. The future is quite capable of devising its own unpleasantness without assistance from Wells. However, there they were, Wellsian or otherwise, unreal but very real, bouncing up and down on their parachutes, rather pretty but very terrible. There was nothing to do except shoot as well. I shot. They were like dolls, marionettes; as the bullets hit them they doubled up, knees came towards chins convulsively and down again. They were seconds only in the air. Those on the left were concealed by the olive trees. Those to the front went mostly the other side of the ridge but two parachutes were plainly visible, grotesque and deflated spread like unnatural washing over the vines - green and brown blotched. The green did not tone with the vines. We waited for movement. Suddenly a man, doubled up, began to double along the vine path towards the ridge. We all fired at open sights. The brown dust spurted round him. He fell out of sight in the olives. Up again, he got almost to the ridge. But this time he fell finally.We felt a savage elation. The second one was moving: but he had to run uphill in the open and the terraces where seconds of delay meant death trapped him. He fell, got up again, fell, up again, then fell finally.

C Company appeared from the left front, counterattacking. One sniper had found us and his bullets were whistling overhead unpleasantly. We could not see him but fortunately he was a bad shot. The counterattack cleared the front.

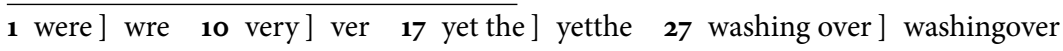

6 HQ Coy HQ] The HQ of Headquarters Company, rather than the company HQ. 
Behind us we could hear a Hun sniper. I set a couple of men to watch. Maj Fyfe and Harry Dalton appeared and were told off by Ginger. He had nearly shot them. We warned them about the sniper and told them the situation. They went off in the direction of the sniper.

Meanwhile my men had become transformed. Vengeful action instead of helpless waiting had remade them. From their first rifleshot they were veterans. Foster had recovered completely. So I decided I could now leave them and report.

On the way down to Bn HQ the hidden sniper took a few shots at me but was still well out. There were dead parachutists everywhere. Most of them had 'died in harness'. One's head was near HQ Company's tea bucket. I removed his cigarette supply and noted he carried a gasmask. Met Dalton who reported Maj Fyfe killed by a sniper. Poor 'Granny'. He had irritated me for days before by his fussiness whenever there were planes about. But when the fighting began he was game enough, reckless even. Possibly to compensate for his previous nervousness. Dalton was cool but his wide grin was that

\section{May 41 contd}

battle-grin: which I shall always regard when I see it again in men as I often did that day as the sign of the most dangerous form of ferocity.

Col Leckie was in his element: he had shot four himself. I set out in the Bren carrier to make a situation report. It was one of those rare occasions when I am thrilled, riding along in this fiery little steel charger, rifle at the ready, dead parachutists everywhere.

At A Coy Karl Watson and I were attacked by a sniper fr across the gully. A patrol was sent after him. Otherwise all was well. At C Coy Major Thomason had shot 7 and nearly been shot himself by Sig. T. Lewis. My own platoon were in grand fettle as I passed them but Sgt Dutton seemed to be too busy souveniring. A prisoner had already shown them how to use German weapons. (No need for months of W.T. to teach these men guns: sheer waste of time) B Coy were doing well: just cleaning up the last sniper and collecting stuff from Hun containers. D Coy had moved through to the village cleaning up and were on their way back. HQ Coy had dealt with their share of the manna.

Back at HQ I reported all well. Before going up to the lookout I decided to investigate a container, hoping for some glasses. There was one across the road and

14 cool but ] coolbut

2 Harry Dalton ] William Henry 'Harry'

Dalton (1913-1965) 23 Battalion assistant quartermaster, an accountant or secretary from Ashburton.

20 shot four himself] Five, said Davin later. ${ }^{311}$

20 Bren carrier ] A lightly-armoured tracked vehicle with a mounted Bren gun. 25 Sig. T. Lewis ] Not identified. Most probably a misreading for Sgt. Lewis. 27 W.T.] Weapons Training. 28 sheer waste of time] c.f. For the Rest of Our Lives, p. 59.

29 Hun containers] The parachutists had additional equipment dropped in containers. 33 hoping for some glasses] German binoculars were prized. 
gully in front of Bn HQ. Bertwhistle, a signaller, and I went out. I found grenades, v. dangerously placed for HQ. Passed them back to B. Squatting on my haunches was about to continue search. A burst of fire, spreading out like a ripple in my fingers and left thigh below the groin. I could see the bright blood welling from my fingers on the clay. Waited for the finishing burst. Very frightened but more angry at being caught so easily. I had been drunk with danger and daring. Firing from my right front: I turned my head. 10 yards away Young and another were looking grimly along their sights. They were at the gully edge. The ground was open olive grove but I could not see the sniper. I called out to Bertwhistle to fetch stretcherbearers and heard him pass the call. He began to climb out of the gully towards me. I called out almost hysterical w quite genuine anger and concern and yet even then self-conscious knowing it was the right thing to say: 'Get back, you silly young bugger. Get back into the gully.' He ignored me and came on. My profanity was punctuated with groans. He began to tug at me and I levered myself along w right arm and shoulder. Another burst of fire and we lay flat waiting for the next flood of pain. None came. I again ordered him back but he would not go. We moved slowly back to a slight depression. Here I had to rest. The gully was about 8 yards away. The stretcher bearers began to climb out of the gully. I ordered them to wait there till we reached them. They blandly ignored me, walked out with their stretcher, put me on it, and carried me off not via the gully but in the open via the road for fear I should be hurt! I shall never forget the courage of those three men and do not even know the names of two of them. The firing continued but it was now a duel between rifleman and M.G. The Hun must have been a gallant fellow. $\mathrm{He}$ could have got us, I know.

Moral: parachutists' containers must be approached w extreme care. Their contents are even more important to the enemy than to you and if he is not strong enough to come and get them he will be quite jealous of anyone else who attempts to do so.

At the RAP wounds bandaged: no bones broken luckily: bullets through ring and second finger of left hand: bullet in thigh retained. In some pain and terrible anger. Morphia. But in a dugout in the gully-side. Rex's platoon went out after the sniper.

3 spreading] apreading 9 fetch] fethc 29 dugout] gugout 29 Rex's] Rax's

1 Bertwhistle] Jack Harrison Birtwistle (1914-2010) A private in 23 Battalion, a storeman from Auckland. He was not a divisional signaller; he may still have been in the battalion signals. However, Davin described him to Winnie as a runner ${ }^{312}$ and to Tony Simpson as 'My runner. ${ }^{313}$

22 M.G] machine gun.

27 RAP ] Regimental aid post.

29 Rex's platoon went out after the sniper.]

This may not be quite accurate; details are confused. Davin said to Winnie 'My old platoon goes out and hunts him down. ${ }^{314}$ Gray, who was near the mortars, recalled 'It had just been reported to me that one section which had been posted on Signal Hill (Platanias 971569) [that is, Lookout Hill] had come down from that position when Lt. R. King and his platoon arrived. Owing to the possibility of the enemy occupying such a splendid O.P. Lt. King took his platoon in that direction. Later a short skirmish took place at the top of the hill. ${ }^{315}$ This may be the information Davin had at the time, but refers to an earlier attack, before Davin and his men re-occupied the hill, as an annotation by Davin to one of Ross's drafts makes clear: 'Fyfe was killed about 9 or 10 o'clock, just after visiting my section and its 
They came back with his MG. He will stay there. Chard came in with his eye shot away. My first sergeant when I was in A Coy long ago.

\section{May 1941 contd.}

Lay there all afternoon and evening talking to our wounded and theirs. Sent for my diary in case of evacuation. Cross-examined parachutists. A German officer and corporal brought in. The corporal was worse hit than the officer but attended to him like a batman. I disliked the officer: too much 'British soldier - good!' about him.

A Coy and a Maori Coy set off later that night to help the 22nd. Our day had been completely successful. The men had fought magnificently: hardly a parachutist could have escaped. Had some beer left over: shared it with our 4 wounded.

The parachutists carried large supplies of cigarettes, dates, sausages, chocolate, energy tablets. An officer was found with French letters in his pocket. They were mostly well built, good-looking - morale on the whole excellent. But they were surprised by our numbers and fighting quality. Had not been led to expect either.

\section{May}

About four in the morning (Wednesday) was awakened and told truck had come. Got painfully out of the gully. The night had been very still: only the frogs and an occasional burst of fire. I had slept with revolver and rifle beside me, two grenades near my head, ready for snipers. Leg now very stiff.

Said goodbye to Ron Stewart and Padre Griffiths. It was cold and the news was bad. The 22nd had been forced to withdraw and A Coy and the Maori Coy had come in with them. Bruce Baxter was on the truck, two tracer bullets in his foot; he had been carried by his men two hours journey. There were some artillery men to be picked up.

9 to help ] tohelp $\mathbf{1 1}$ left] sleft $\mathbf{1 7}$ awakened ] awkened

look-out post on a hill SE of Bn HQ, about 100 yds. I imagine by an isolated parachutist. I was wounded about $2 \mathrm{pm}$ after the landings had ceased by an isolated parachutist who had a Schmeisser. A party, perhaps from 14 [Rex's platoon], went out after the Jerry but this was quite separate from Rex's earlier attack which, as you say, was very successful. ${ }^{316}$

1 Chard ] Charles Lambton Chard (1917-2004) Sergeant in 23 Battalion, a regular soldier originally from Inglewood.

9 A Coy and a Maori Coy set off later that night to help the 22nd. ] 22 Battalion were defending Maleme Airfield; by the time A Company arrived, 22 Battalion's commander had decided to retreat.
13 energy tablets ] There seems to have been a persistent rumour that German paratroopers were using amphetamines or energy tablets of some kind. Short of rations while retreating, Len Diamond found himself looking at some captured tablets. 'The boys reckoned they were dope [...] I cleaned up half-a-dozen of them and still retained my senses. They certainly made me feel a bit more alert, but when that wore off one could fall asleep standing up. ${ }^{317}$ Captured tablets were subjected to assay after the battle and found to be nothing more than atebrin tablets used as anti-malarials. ${ }^{318}$ 21 Padre Griffiths ] Robert John 'Bob' Griffiths (1905-1977) The 23 Battalion chaplain, a Presbyterian minister from Waimate. 
At last we got away, two trucks and a Bren carrier between. There were enemy along the road. I was supporting Bruce on one arm. My right arm I kept free, revolver in hand in case of trouble. I was the only armed man.

So goodbye to the $23 \mathrm{rd}$. I felt like a rat leaving them but could be no use in staying. I was the more uneasy because I knew the price had been so cheap.

Reached the 5th Field Ambulance without mishap. Did not like to push forward when there were so many worse wounded. Lusk found me sitting in the passage. Went into the dressing room and wound was dressed. In came Hawksworth. Here was his chance. Obviously the ideal moment for a little forgetting and forgiving. He came up with outstretched hand. I resented the dramatic appropriateness of the situation but was too weak to resist its cogent sentimentality. I took his hand. He beamed. Social contact was re-established, the decencies had been observed. I smiled wryly.

Ralph Park and Geoffrey Palmer appeared. Also Selwyn Clive-Lowe. It was pleasant to be with old friends.

Lay in a stretcher between Bruce and a couple of Jerries. Talked to them most of that day. They were not bad fellows: one had been a foreman, another had been a Kaufmann. Both had been in France and Poland. A third very young and handsome was an architect. Wounded came and went all day. We drank tea from old tins. Greek civilians peeped with inquisitive sympathy through the windows. Two swallows flew and made love in the high-raftered ceiling. [/// The building was a school. DMD $1979 / / /]$

Could not sleep that night in spite of another shot of morphia and some pills. Mind was still $\mathrm{w}$ the $23 \mathrm{rd}$.

Bad scene during the day. Very heavy air mging round about; then parachutes landed about $400 \mathrm{yds}$ in front. We cd see them running through the trees. A few Gks fr the village grabbed old rifles and went after them. We thought we were done as the

17 Kaufmann ] Kaufman

6 Reached the 5th Field Ambulance] Stewart believed that the thirty wounded evacuated with Davin did not go to 5 Field Ambulance; 'since the trucks and carrier were proceeding to the Canea area for unit supplies, these 30 wounded were taken to $6 \mathrm{Fd} \mathrm{Amb}$ at the Galatos road junction area. ${ }^{319}$ This appears to be an error on Stewart's part. 7 Lusk] William Brian de Laval Lusk (1915-1977) A medical officer in 5 Field Ambulance. He was educated at Otago, graduating in 1939, and was briefly a house surgeon at Auckland Hospital before the war. He was taken prisoner in Libya later in 1941, and became a pathologist after being repatriated in 1944.
9-11 He came up with outstretched hand. I resented the dramatic appropriateness of the situation but was too weak to resist its cogent sentimentality. I took his hand. He beamed. ] 'The latter came at me with outstretched hand. Now was my opportunity. Of course I would take the opportunity. I took the hand. If he believes in such things as forgiving and forgetting more fool he. ${ }^{320}$

17 Kaufmann ] Shopkeeper.

24 mging] machine-gunning.

26-1 the parachutists had cleaned up the 7 th General and the 6th Field ] Both units were captured and then re-captured by New Zealand troops. ${ }^{321}$ 
parachutists had cleaned up the 7 th General and the 6th Field. Col Twigg burnt his papers. The prisoners swore we wd be allright provided there was no firing. They had their boots and helmets

\section{May 1941 contd.}

put in the window to prevent hasty attack. One sat at the door for a parley. As there was nothing else to be done I resigned myself to death or capture. One of the wounded Jerries wanted me to hide behind him in case there were any shots flying. But that would have been very undignified and wasn't worth the trouble. I felt quite tranquil. All the time these days I had thought of Winnie and Anna. There is great comfort in picturing those two: they complete each other.

But meanwhile the Maoris had attacked fr the right, the engineers fr the the left and the enemy were cleaned up. From now on there was terrific MG fire and cannon fire fr an endless series of Messerschmitt 11os. Noise like the ripping of vast stretches of linoleum. But it was obvious that they were respecting the Red Cross as the fire always stopped within a chain of us. The medical orderlies showed great courage as did everyone else. Though how often these days I have seen eyes great and dark with pain and fear.

Next day we moved into a vacated house next door. There were fine red curtains on the windows and real beds. [(22 May)]. The first I had lain on for months. Everybody was very good to us and considerate. I was much tormented still by fleas and not in much of a condition to defend myself but I caught one and killed him with vast satisfaction. To have brought down a plane could not have given me more pleasure.

22 May, Thursday.

\footnotetext{
28 prisoners ] pri oners $\mathbf{2 8}$ They] The $\mathbf{2 9}$ helmets ] helmets put 40 series] seriies 40 Messerschmitt ] Messerschmidt

27 Col Twigg] John Martin Twhigg (1900-1970) A Wellington medical practitioner, the commanding officer of 5 Field Ambulance. After being taken prisoner and then repatriated, he became ADMS of $3 \mathrm{New}$ Zealand Division in the Pacific. 27-28 burnt his papers] These were his

'codes and secret papers.' ${ }^{322}$

38 the engineers] The engineers were 19 Army Troops Company, a non-divisional unit, who had to fight as infantry. ${ }^{323}$ 41 respecting the Red Cross ] It was illegal to attack hospital units, which displayed a red cross as identification.
} 
Early that morning the 2oth and the Maoris had counterattacked as far as the drome. But the attack was too late starting air support did not materialise and the navy had found the German sea transports and were busy knocking them to hell. The counterattack was forced to fall back again. This was the second crucial stage: the first was the opening attack. With another battalion across the Tavronitis we cd have held Maleme. And had this counterattack had support and greater numbers we cd have retaken Maleme. In either event we would have had the first land victory of the war and kept Crete. As it was it was touch and go.

Jerry now had a Bofors wh the Tommies had left without spiking. This did terrible damage as did his $5 "$ mortars. We had more casualties fr these than anything.

In the afternoon Ivan Patterson turned up, concussed and shaking. Also Peter Brant, MG officer fr Maleme wounded in thigh and arm. He had been wandering three days and two nights among the Jerries with neither food nor drink, half delirious. Frogs had led him to water or rather slime wh he drank fr a tobacco tin. There were dead Jerries in it. He saw hundreds of dead Jerries, only two New Zealanders. We were still holding the Pyrgos line. Everyone said our men were fighting w superb dash and courage. The Maoris' hakas were terrible to hear. Harding Leaf was dead: he had

2 was too late starting] 20 Battalion were under orders not to move until relieved by Australian forces because of the threat of landings from the sea; the Australians were late arriving, delaying their move out and thus the attack. $^{324}$

2 air support did not materialise ] It is not clear what happened here. 'Creforce arranged with GHQ Middle East that the airfield should be bombed between midnight and two o'clock in the morning. ${ }^{325}$ Davin's history does not note them again; a later report states baldly that 'The bombing of the aerodrome however did not take place. ${ }^{326}$ and leaves it at that. Perhaps the delay in the counterattack was responsible, but communications were so poor it seems unlikely the RAF were aware of this. Four Blenheim bombers attacked Maleme on the afternoon of the $23^{\text {rd }}$.

2-3 the navy had found the German sea transports and were busy knocking them to hell ] Two convoys of small boats were intended to carry German troops into action at Maleme and Heraklion. The first group were intercepted and destroyed in the early morning of the twenty-first and the second turned back. ${ }^{327}$ From the New Zealand Division's perspective, 'most violent gunfire was heard 18 miles seawards, NNE of CANEA which recurred at intervals until dawn 22 May and came within 10 miles of CANEA. Starshell, gun-flashes and the glow of fires at sea were clearly visible. ${ }^{328}$

9 a Bofors ] An anti-aircraft gun of Swedish design.

10 his 5 " mortars ] These were dropped from the air.

11 Ivan Patterson ] Ivan Hislop Patterson (1894-1973) 23 Battalion Quartermaster. A traveller in dairy machinery from Dunedin. 11-12 Peter Brant ] Percy Anthony Matthew 'Peter' Brant (1907-1985) Officer in 27 (Machine-Gun) Battalion, the commander of 11 Platoon, 4 Company. He had had command of four guns on a ridge overlooking Maleme, below Point 107 and was left behind when 22 Battalion withdrew from there. ${ }^{329}$

One of relatively few regular soldiers in the New Zealand Division, he started the war as a Sergeant-Major.

16 the Pyrgos line] The line established around the villages of Pirgos and Maleme and the ridges south of them to hold off attacks from Maleme aerodrome and allow a counter-attack. This was held by 20 and 28 Battalions.

17 Harding Leaf] Harding Waipuke Leaf (1890-1941) A World War I veteran serving as a 
been taking a platoon along the road in the dark. Huns dressed as NZers halted them. He went up, became suspicious, called back 'Fan out, boys' and was riddled with a Tommygun. A great warrior. The Maoris attacked and killed all the Jerries. Further back they had attacked and bayoneted 32 .

A shot struck an artillery ammo dump about 40o' fr the 5th Field. For what seemed like hours we could hear the shells exploding and sigh overhead as if deprecating helplessly their involuntary flight. This was more terrible than deliberate fire. Chance entirely governed their billets. But we were not hit.

By now one of our company, an officer of engineers called Patterson, was beginning to show himself an intolerable bore at least to me who have been granted by nature a subtle intuition for the early detection of bores. But usually one is able to save oneself by flight. Here flight was impossible.

Friday, 23rd May.

At two on Friday morning Colonel Twigg appeared. Transport was arriving and we were to leave when it did. I gave him the diary I had lately begun as they were short of paper. In about an hour the transport arrived and we tottered into ambulance saying goodbye to the 5th Field. If every unit was as hospitable, efficient and human as this the wounded soldier wd have a much less terrible time.

The tobacco situation had been saved for me by Sergeant Bevin here with dysentery. He had already given me one tin of Three Castles tobacco and now gave me another. Thus I was able to keep Bruce, Peter, occasional guests and myself going.

There were four stretcher cases here: they suffered hell along the rough road, bad in the first instance and now battered w shell-fire and grenades. Guns and men were going forward. Ivan's waterbottle went constantly round the four stretchers. One was a Maori badly smashed, another a German. Poor fellow, he was relieved when I answered him in his own tongue. All three Jerries spoke with constant nostalgia of the Heimat.

9 Patterson ] Pattereson

captain in 28 Maori Battalion. He was a health inspector from Whirinaki.

1 Huns dressed as NZers ] Not the case; a German order captured on Crete explicitly stated 'The Divisional Commander has forbidden the wearing of English uniforms. Units will be so instructed. ${ }^{330}$ The rumour probably originated because 'By some mischance Captain Leaf led C Company through the forward troops without knowing it and was killed at a bridge some distance in front of the start line. ${ }^{331}$

\author{
9 Patterson ] David Moore Patterson \\ (1910-2001) Lieutenant commanding No. 4 \\ Section, New Zealand Engineers. A civil \\ engineer from Oamaru. \\ 20 Sergeant Bevin ] James Arthur 'Jim' Bevin \\ (1911-1980) Sergeant in the intelligence platoon \\ of 23 Battalion, a Dunedin clerk. \\ 21 Three Castles tobacco ] A British brand of \\ Virginia tobacco. \\ 27 the Heimat ] Homeland, place of \\ belonging.
}


Confusion at the 6th Field. It had vanished We went on to the 89th, a Tommy place. The hospital was overflowing and we overflowed also into the chief cathedral of Crete. It was very dark and gloomy after the early sunlight. We lay on blankets on the stone floor against the wall. In front of me was a picture of the Archangel Michael standing disinterestedly on a diminutive and tonsured figure whose identity I cd not ascertain but who seemed to be bearing up fairly stolidly under the angelic weight. It was a very bad picture as were all the hundreds of others I could see. But for me the church was on the whole soothing, strangely reminiscent of old childish days. And I liked the smell of incense. Greek women and old men came in and out constantly, pausing to pray a while before the ikons. A young Belfast doctor inspector looked at our wounded, a little Lancashire lad dressed them. We drank tea from bowls and ate the usual stuff, this time with bits of stick. Bombing and machinegunning outside but about a mile away. Towards evening Greek girls came round gravely and gave us a flower each. I was lucky and got a rose and a carnation. I have always loved carnations, the first flowers I can remember, growing in our garden in Gore. And the name pleased me even before I knew its derivation. That night I slept.

8 whole ] who e

1 It had vanished] 6 Field Ambulance had been captured by paratroopers on the day of the invasion, ${ }^{332}$ then released by 19 Battalion. They had reassembled late on the night of 21 May to form a dressing station in a culvert under the Maleme to Canea road, about a mile and a half from their previous location. ${ }^{33}$

1 89th, a Tommy place ] Actually, the 189th. ${ }^{334}$ 12 stick] Bread.
13-14 Towards evening Greek girls came round gravely and gave us a flower each. I was lucky and got a rose and a carnation. ] C.f. 'Danger's Flower', where 'Two girls came around with baskets full of flowers and gave each man a rose or a carnation [...] They used to grow in the front garden at home when he was a boy. They were the first flowers he remembered.' ${ }^{335}$ 


\section{Appendices}

\section{Appendix A: The Relationship Between Diaries and Fiction}

\section{For the Rest of Our Lives}

For the Rest of Our Lives is heavily autobiographical. It is based on the wartime experiences of three characters, Tom, Frank and Tony. John Willett's verdict was that what Davin 'had done was to take yourself, Paddy and Geoff, roll into one large lump and chop into three.' 336

As such, the novel draws from Davin's wartime experiences on almost every page; it is more difficult to say what draws from the diaries and what in the diaries draws from a shared source.

In some cases, as for example when Davin notes the phrase 'ringtailed snorter' without explanation in May 1943, and then uses it on page 54 of For the Rest of Our Lives, the correspondence is clear. In many other such cases, a phrase in the diaries is recycled. There are too many such echoes to record fully; those which appeared originally in this selection from the diaries have been noted. The most substantial section to appear almost unchanged is a long discussion of the song 'Lili Marlene'. ${ }^{337}$

Davin's combat experiences in both Greece and Crete appear in the novel, but in substantially expanded form to the accounts in the diaries. A similar phenomenon appears many times: a party with a blind pianist, a story told by Forsman to Davin, a meeting in Cairo with the other officers of 23 Battalion, and so on. But always new material, some of it verifiable from other sources, leaks in.

It seems that Davin is writing from recent memory more than he is rewriting the diaries; they are a parallel rather than a source. However, Davin does at one point wonder if it is worth beginning his new novel 'without my old diaries' (presumably with Winnie in Bristol). ${ }^{338}$

\section{The Salamander and the Fire}

In contrast, Davin's short stories set during the war are more rewarding to examine. They are written either contemporaneously or some years later. As such, they are either written in parallel with the diaries, sharing ideas more noticeably, or much more heavily based on them than increasingly distant memories. 
There are three groups of short stories about the war; the majority were published in The Gorse Blooms Pale in 1947, then a handful more in Breathing Spaces (1975) and the last few, as discussed, after Davin retired and began to transcribe the diaries.

\section{The Gorse Blooms Pale}

Below the Heavens 'Below the Heavens' is set on Olympus, but the characters come from Rex King's 14 Platoon, not Davin's 13 Platoon. A German soldier is wounded and calls out for help. A soldier goes to him, saying that he'll kill him; finds him and intends to help him; and then shoots him in an act of mercy.

The events described get only a few lines in the diaries (19 April 1941):

they filtered in behind the right flank and shot at 3 Section from behind. Quin with some skill drove them off. I applied for a patrol and got them chased out, some staying for good in front of 14 [Platoon].

But the diaries provide us a way to trace the development of the story:

14 November 1942 has Davin writing 'X Gillespie and the wounded man at Olympus: with something from the other wounded story in the desert.' (Davin uses an X to mark intended stories in the manuscript.)

Gillespie is John Gillespie, who died of wounds in 1941. There is no other account of his story, but Brian Bassett wrote that 'A wounded man out in No Man's Land was groaning and calling out "Help" in English. When I got this report, I fancied it might possibly be Paul [Campbell], and as he was a friend of Uncle Jack I went down cautiously with my heart in my mouth to the wire, but there was nobody there but Jerries - in shorts and grey jerseys like our fellows.' ${ }^{339}$

On the $9^{\text {th }}$ of December, Davin records that he 'Wrote a short story this morning about Olympus but without elan. Shall improve it later.' The day before, he had been reading Blake, and the vision of Olympus as a place where mercy is murder, as 'a place where Contrarieties are equally True' 340 can be read as owing something to Blake's apocalyptic visions.

Under the Bridge This story is, as its vagueness - what Janet Wilson has called its 'subjective, impressionistic mood'341 - suggests, one of very few of Davin's stories not based at least partially on his own experiences. Rather, it is a rendition of a story someone else told him.

In September 1941, Davin tells us, a friend of his flatmate Julius Edwardes visited.

Told good story. Woman and granddaughter insisted on sheltering under a road bridge $w$ about 50 others. The blitz on. He was on a hill $500 \mathrm{yds}$ above watching. Bombs falling. Women kneeling, crossing themselves in calm. Disappear in dust. Dust clears and a black shambles, spread and slightly stirring. When blitz slackens, goes down. 20 yards away all is silent, nothing stirs. He can see, feel, the blood and slaughter. Sickened already, he cannot go on. Goes back. 
From this, Davin develops the much longer 'Under the Bridge' without adding to the basic premise.

The General and the Nightingale This story is a curious case, in that its central event really happened while Davin was present, at Cassino, but does not appear in the diaries.

An account is given by W.G. Stevens, the chief adminstrative officer of the division:

One morning the General went to visit forward troops in his jeep. He sat alongside his driver Cpl. Noris, with the CRA Steve Weir and his ADC Murray Sidey in the back. All was quiet; then just as they slowed down to cross the bridge the General said: "Pull up, Norris", and after a few seconds: "I'm sure I heard a nightingale. Let's wait and listen for it." Three people in the jeep were listening for only one thing, the sound of mortar rounds leaving the barrel. ${ }^{342}$

Davin records none of this; the diaries' incidental contribution to the story comes in the figure of the 'I' Officer who talks to the general. A raid on the International Post is mentioned in both and dates the story to late April 1944. But the general's conversation is taken directly from the entry for 18 February 1944:

The Russians have Staraya Russa. In the pocket 52,00o killed, 11,00o PW. 'Killed,' says BF, 'killed? He said killed, did he?' 'Yes, killed, sir'. 'Killed, eh?' 'Yes, killed, Sir.' 'Killed, eh. Good.'

This becomes

'Good, good,' says the Old Man. 'Killed, eh? You did say killed?'

'Killed, sir'

'Good, good.' 343

Bourbons and Unwrung Withers These two stories form a special category, both being more or less imagined and making a distinct political as opposed to artistic point.

In 'Unwrung Withers', Mr Cuff, a self-important speechmaker, delivers a speech in Palestine while missing the point. He claims solidarity with Jewish suffering while enjoying a good grill and a picture in the Palestine Post.

There are no echoes of the diaries here, perhaps because the setting is based on Davin's experiences of Palestine at Staff College, a period very briefly covered in the diaries.

The one possible hint is Davin's review of the film Mrs. Miniver at this time, which he criticizes for its 'apologia for conventional Anglicanism, aristocracy, and suburbia all clumsily combined. ${ }^{344}$ The film shows the minimal sufferings of suburbia in wartime in a way that seems almost designed to inspire Davin's resentment.

'Bourbons' is another interesting case; it shows officers like - the original title - 'Bourgeouis Bourbons' unaware of the imminent revolution. Three officers in an 
'independent unit', like J Squadron, listen to the news, and, again, miss the point. They fail to recognize the significance of Russian advances, and imagine that nothing will change after the war. 'They retrospect and anticipate while listening to the news. And they hear of the battles of Stalingrad. Must be sympathetic but final. Unemployment and conscription.' 345

The reader may feel that Davin never solved the second of the two problems he identified in the rough draft of Bourbons:

Non satisfaci unsolved (1) how to describe bores without being boring (2) how to balance the first half against the second without doing what seems to my intuition clumsy, pointing the end too much. ${ }^{346}$

Mortal This story about death and last things has no obvious parallel in the diaries.

Liberation Another anecdotal story, this one is based on 'the tremendous pregnant woman who came in to the Engineers and lay down on the bench. This had been the only way to get mangiare and she assumed it was still. Pregnant women patting their bellies and saying: Tedeschi. ${ }^{347}$ Davin expands the anecdote and retells it in New Zealand vernacular.

Danger's Flower 'Danger's Flower' combines Davin's own experiences in the cathedral on Crete after being wounded, closely following the diary account, with a story he heard soon after in hospital: 'Heard a good story yesterday: Woods badly shocked when evacuated fr the Kania cathedral began to walk to Sphakia. On the way he picked up a sergt with a shrapnel wound in the bottom. He half carried half dragged this man for 12 miles. Each was terrified of losing the other. They were blown up twice. Every morning Woods wakes up seeing the sergt's eyes staring from smoke and dirt blackened face, swivelling uneasily after every movement Woods made, fearful of being abandoned.' ${ }^{488}$ The blond young boy from the Black Watch whom Davin saw in the cathedral is turned into Woods' sergeant.

In Transit, Jaundiced, and Not Substantial Things These five stories are very closely - taking whole paragraphs at a time - based on episodes in the diaries. 'Jaundiced' retells Davin's experiences in hospital with jaundice; 'In Transit' his return from leave to Italy and train trip up from Bari; 'Not Substantial Things' an expedition he and Dick White went on to liberate an Italian village.

\section{Breathing Spaces (1976)}

The Persian's Grave The diary allows us to infer the genesis of this story, in which an escaped New Zealand prisoner is captured by an Italian patrol while drunk, but does no more than that. On 8 November 1941, Davin writes: 'Australian drunk and lost in Athens meets Italian patrol' without explanation. On 1 August 1942, a list of potential stories has 'Australian in Athens'; this appears again on the $22^{\text {nd }}$ of September. 
Pyschological Warfare at Cassino There is no known source for the central premise of this story (that an American officer tried to persuade Davin to put propaganda leaflets in mortar bombs.) On the other hand, many small fragments from the diaries are incorporated into the story. This much later story very obviously draws on the diaries as a reminder of events, more deeply so than earlier ones did.

Sabretooth, the nickname Davin gives to the formidable staff officer Ray Queree, one of the unsung heroes of the war because of his relentless focus on efficiency at all costs, is here called by the same nickname. One of his lines Davin notes under the heading 'Illusions we entertain about ourselves', 'I' $m$ not one of you clever, educated fellows' 349 becomes 'You clever, educated blokes.'

The same lines about Starya Russa are repeated.

Meanwhile, the entry for 15 March 1944 becomes an important part of the story.

The bombing of CASSINO has been going on for an hour. Hordes of generals and war correspondents about at 0630 this morning. I lay low in my bed and listened to the Russian news. A lovely morning with a nip in the air. The dull angry buzz of the planes comes and goes every quarter of an hour. Jack Reynolds will be in the first assault wave. His note to Toby [Lewis]: " 800 yds from the Monastery. Four hundred yards from the town. Losing weight fast. Regards. Jack." Freyberg very elated today that things have begun. Have had a busy time squashing his parachutist story.

In 'Psychological Warfare at Cassino' the narrator lies in bed and listens to the news. Then he has to counter a rumour spread by the General that the paratroops have been leaving the front, presumably the 'parachutist story.' He repeats the lines about Starya Russa already quoted to the General and mentions the rumour as part of his programme of psychological warfare to restore the 'mana' he has lost after Des Cassidy (Paddy Costello) left on leave. ${ }^{350}$ Then,

Just before I went to bed that night, 14 March, a runner brought me a note from a friend who had one of the forward companies and was to go in with the first wave of the assualt. ' 800 yds from the Monastery. Four hundred yards from the town. Losing weight fast. Regards. Jack.' I thought of him a lot before I went to sleep. At first I thought I knew how he felt. Then I realized I only remembered how he felt.

Well, the newspaper boys were around in swarms by 06.30 hours... 351

Coming And Going See the discussion of probable sources in the introduction.

\section{The Salamander and the Fire (1986)}

For the five stories collected in The Salamander and The Fire, see the brief discussion in the introduction. 


\section{Appendix B: Sample Images}

Figure 1: The first page of this selection in the typescript.

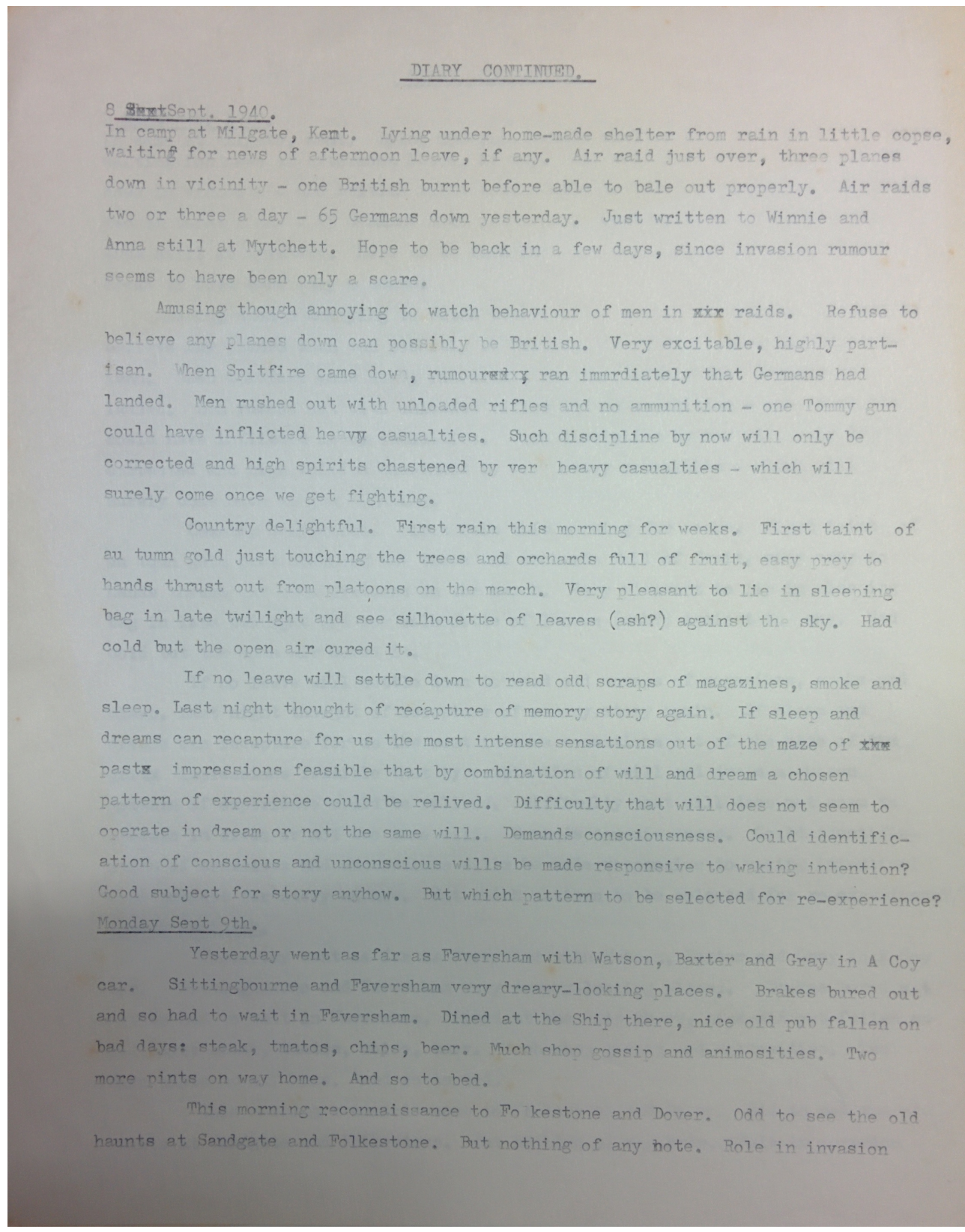


126

Figure 2: The first page of this selection in the holograph.

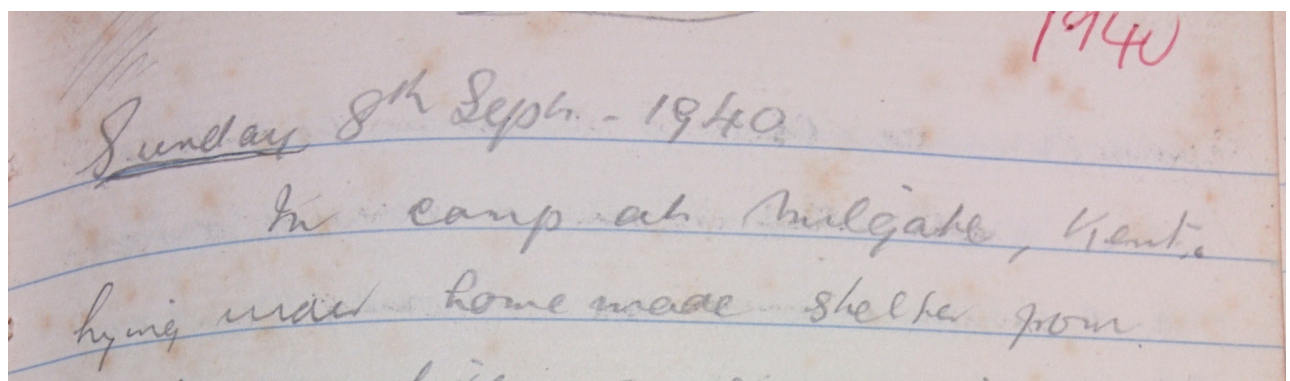

rand in hivice capse cwail ip

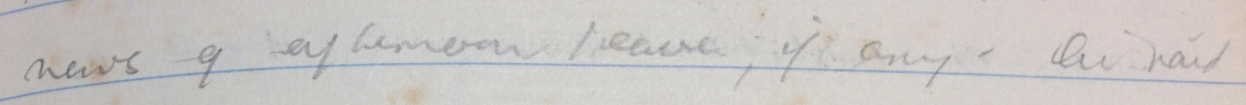

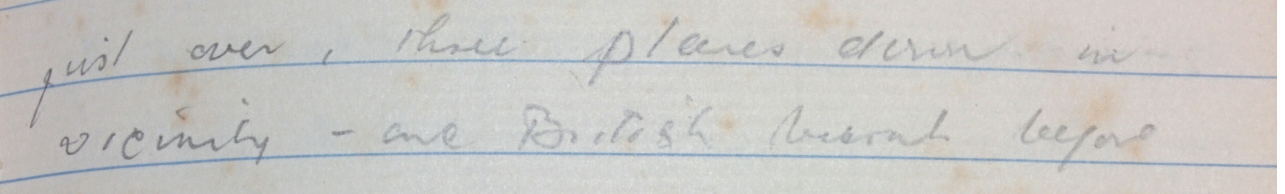

able lo bace but poperg. Qu tiana

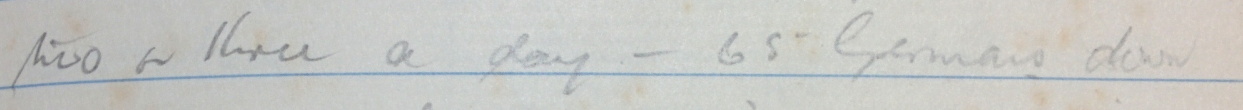

yesterday. Yush workin how wive

* Amna sitil al hy elert. Hopo to

the leark a few grey \&, fince

moision rumour semen tohave been

ent a seare.

Anussing tharigh aunoying o

warch behavivion of mear an rado

Ryure bletwe any planes dand.

car passilg be boilesh bery

exclable, hichly partisan. Wher 


\section{Notes}

1. Dan Davin, Closing Times (London: Faber \& Faber, 2010), 47.

2. M.K. Joseph, Old Sacred Heart College, 1927-30, MS-Papers-6678-058, ATL, 2.

3. Dan Davin, Norman Davis: The Growth of a Scholar, ed. Douglas Gray and E.G. Stanley, An Offprint from Middle English Studies presented to NORMAN DAVIS in Honour of his Seventieth Birthday (Oxford: Clarendon Press, 1983), 4.

4. Quoted in Keith Ovenden, A Fighting Withdrawal: The Life of Dan Davin: Writer, Soldier, Publisher (Oxford: Oxford University Press, 1996), 243.

5. Paddy Costello, Diary, Private hands., 26 May 1943.

6. Davin, Norman Davis: The Growth of a Scholar, 10.

7. Geoff Flavell, Letter to Dan Davin, February 2, 1986, MS-Papers-5079-019, ATL.

8. Dan Davin, Letter to James Bertram, March 6, 1982, 93-133-30, ATL.

9. Robert D. Denham, ed., The Correspondence of Northrop Frye and Helen Kemp, 1932-1939: 1936-1939 (Toronto University Press, 1996), 654.

10. Eric McCormick, comp., Dan's Funeral: 1.10.199o, MS-Papers-5292-013, ATL, 1990.

11. Davin, Closing Times, 46.

12. Geoffrey Cox in Michael Fathers, Sir Geoffrey Cox Material, MSDL-0359, ATL, 2006.

13. C.K. Allen, Warden of Rhodes House Report, Davin File, Rhodes Trust Archives, Rhodes House, 1936/37. 14. Dan Davin, Letter to Howard Kippenberger, January 4, 1949, IAI 181/32/2, National Archives, Kew, London.

15. Davin, Closing Times, ix.

16. Dan Davin, Letter to Geoff Flavell, March 29, 1979, MS-Papers-5079-019, ATL.

17. M.K. Joseph, "Travel diary" (MSX-7471, ATL).

18. Davin's friends were invariably well-educated. University-educated men, or even white-collar workers like the clerks and teachers who made up much of the officer class, were rapidly promoted based on talent, but it was not until later in the war that there was a 'move towards more selection on military merit rather than occupational status.' (John Reginald McLeod, “The New Zealand Soldier in World War II: Myth and Reality" (master's thesis, Massey University, 1980), 36)

19. Tony Simpson, Operation Mercury: The Battle for Crete, 1941 (London: Hodder \& Stoughton, 1981), 92.

20. Dan Davin, Letter to James Bertram, March 30, 1982, 93-133-30, ATL.

21. Richard Kisch, The Days of the Good Soldiers: Communists in the Armed Forces WWII (London: Journeyman, 1985), 19.

22. Victor Selwyn, ed., Return to Oasis: war poems and recollections from the Middle East, 1940-1946 (London: Shepheard-Walwyn for Poetry Editions London for the Salamander Oasis Trust, 1980), xxv.

23. Dan Davin, "Paddy Costello" (MS-Papers-5079-435, ATL, 1982), 6.

24. Dan Davin, Letter to C.K. Allen, December 26, 1941, Davin File, Rhodes Trust Archives, Rhodes House. 25. Diary entry for $25^{\text {th }}$ August 1942. 
26. Dan Davin, “Three Encounters Thirty Years Ago,” Islands, no. 21 (March 1978): 304.

27. Thomas arrived too, after a year on the run in Greece, to be greeted by Davin and Cox's attempt to persuade him to submit a request for compensation, among other escape expenses, for the 'Cost of meeting masculine needs while on the lam.' (W.B. 'Sandy' Thomas, Pathways to Adventure: An Extraordinary Life, ed. Denis McLean (Terrace Station, Hororata: Dryden Press, 2004), 6o)

28. Gilles Perrault, "Henri Curiel, citizen of the third world," https : //mondediplo . com/1998/04/ 13curiel, Le Monde Diplomatique, April 1998.

29. Giles Perraut, A Man Apart: The Life of Henry Curiel, trans. Bob Cumming (London: Zed Books Ltd, 1987), 84 .

30. Diary entry for $24^{\text {th }}$ November 1942.

31. At this point a note on nomenclature is called for. Davin's new rank was to be General Staff Officer, Grade 3, Intelligence, universally shortened to G3I. (R.W. Bell, "Intelligence at a Divisional Headquarters" (DA 21.1/10/8, Archives New Zealand)) His reference to GSI 1 indicates that he would be the primary intelligence officer on the divisional general staff; meanwhile, 'the Div. IO [Paddy Costello's role] was second in command to the GIII (I).' (Geoffrey Cox, "History of Military Intelligence in the 2NZEF" (2003-005-3/15, ATL), 2)

32. Diary entry for $14^{\text {th }}$ May 1943 .

33. Dan Davin, The Salamander and the Fire: Collected War Stories (Auckland: Oxford University Press, 1986), 119.

34. M.A.J. Malcolm, Letter to NZ Mil HQ (UK), January 29, 1945, A20o/D5, Archives New Zealand.

35. Dan Davin, Letter to C.K. Allen, August 5, 1944, Davin File, Rhodes Trust Archives, Rhodes House.

36. Dan Davin, Letter to William George Stevens, March 4, 1966, 84-0o6-1/o2, ATL.

37. Keith Ovenden, "Davin, Dan," in The Oxford Companion to New Zealand Literature, ed. Roger Robinson and Nelson Wattie (Melbourne: Oxford University Press, 1998).

38. Ovenden, A Fighting Withdrawal: The Life of Dan Davin: Writer, Soldier, Publisher.

39. James Bertram, Dan Davin, New Zealand Writers and Their Work (Auckland: Oxford University Press, 1983).

40. James McNeish, Dance of the Peacocks (Auckland: Vintage, 2003).

41. Janet Wilson, ed., Intimate Stranger: Reminiscences of Dan Davin (Wellington: Steele Roberts, 2000).

42. Diary entry for $22^{\text {nd }}$ April 1942.

43. Davin, The Salamander and the Fire: Collected War Stories, 172.

44. Dan Davin, Letter to Laurie Nathan, October 11, 1982, MS-Papers-5079-426, ATL.

45. Michael King, Letter to James McNeish, August 31, 1998, MS-Papers-8752-034, ATL.

46. Michael King, Letter to Winnie Davin, November 7, 1990, MS-Papers-8752-034, ATL.

47. King, Letter to James McNeish.

48. King did not send them to Walker, (Geoff Walker, Personal communication, July 1, 2015) or to Christine Cole Catley; (Jenny Catley, Personal communication, July 28, 2015) his daughter is unsure of any other possibilities. (Rachel King, Personal communication, July 1, 2015) The security services are not aware of their current location. (Rebecca Kitteridge, Personal communication, May 29, 2015)

49. Geoff Walker, Letter to Michael King, April 5, 2000, MS-Papers-8752-034, ATL.

50. Kitteridge, Personal communication.

51. Dan Davin, Letter to Dick Hughes, July 31, 1983, MS-Papers-5079-426, ATL.

52. Angus Ross, 23 Battalion, Official History of New Zealand in the Second World War 1939-45 (Wellington, New Zealand: War History Branch, Department Of Internal Affairs, 1959), http: //www .nzetc . vuw . ac.nz/tei-source/WH2-23Ba.xml. 
53. Rachel Elizabeth Bell, "Memory, History, Nation, War: The Official Histories of New Zealand in the Second World War 1939-1945” (PhD diss., Massey University, 2012), 141.

54. Angus Ross, Letter to John Clark, June 15, 1946, MS-2699/o28, Hocken.

55. Alf Jeavons, Letter to John Clark, June 24, 1946, MS-2699/o28, Hocken.

56. Geoffrey Cox, comp., “Scrapbook on his war years” (MSY-5579, ATL, 1940-1945).

57. Dan Davin, The Battle of Crete, Script of BBC programme produced by Leonard Cottrell, broadcast 22 July 1951. MS-Papers-5079-338, ATL, 1951, 13.

58. Howard Kippenberger, Letter to Angus Ross, December 16, 1946, MS-2702/o05, Hocken.

59. John Clark, Letter to Angus Ross, November 26, 1946, MS-2702/005, Hocken.

6o. On Crete: 'Charlie Upham (J.H.U's son) was another hero amongst a score there. With four men he captured twenty, but had to shoot them and says it was pathetic polishing off the last two pleading wrecks, but one couldn't trust them as they treacherously used bombs cunningly hidden.' (Brian Bassett, “Typescript Letters of Lt Brian Bassett pt. 1," ed. Joyce Bassett (MS-2702/oo2, Hocken), 414)

61. Davin, The Salamander and the Fire: Collected War Stories, 123.

62. J. Auchinleck, Letter to Bernard Freyberg, February 2, 1942, WAII8 4, Archives New Zealand.

63. J.O. Ewart, Letter to Geoffrey Cox, July 24, 1942, 2003-005-5/13, ATL.

64. Diary entry for $24^{\text {th }}$ September 1942.

65. Artemis Cooper, Cairo in the War: 1939-1945 (London: Penguin Books, 1989), 214.

66. Peter Norris, Letter to Family, April 28, 1942, MS-2699/o11, Hocken.

67. Ross, Letter to John Clark.

68. A useful summary of this incident is given by Glyn Harper. (Glyn John Harper, "Kip. Major General Sir Howard Kippenberger, KBE, CB, DSO and Bar, ED: A Study of Command" (PhD diss., University of New England, 1996), 192) His statement that the officer had an MC from the First World War is, however, incorrect; he was awarded one after Crete for his 'personal example of continuous conspicious gallantry and devotion to duty in very adverse circumstances', the decoration to which Norris refers. ("Citations for medals awarded during the Crete campaign" (MS-Papers-5079-362, ATL))

69. Howard Kippenberger, Letter to J.L. Scoullar, July 17, 1951, WAII 11/6, Archives New Zealand.

70. Howard Kippenberger, Letter to Angus Ross, July 2, 1954, MS-2699/028, Hocken.

71. Davin, The Salamander and the Fire: Collected War Stories, 45.

72. “Soldier M.P.: Death on Service: Lieutenant Hultquist: Illness While on Leave," New Zealand Herald, November 5, 1941, no. 24114, 6 .

73. Bernard Freyberg, Telegram to Peter Fraser, November 6, 1941, DA 1/9/5/3, Archives New Zealand.

74. Davin, Norman Davis: The Growth of a Scholar, 1-2.

75. Angus Ross, Letter to Doug Leckie, February 4, 1947, MS-2702/005, Hocken.

76. McLeod, “The New Zealand Soldier in World War II: Myth and Reality," 39.

77. Kenneth G. Wynn, Men of the Battle of Britain: A Biographical Dictionary of the Few (Barnsley, S. Yorkshire: Frontline Books, 2015), 84.

78. Basil Collier, The Defense of the United Kingdom, ed. J.R.M Butler, History of the Second World War: United Kingdom Military Series (London: Her Majesty’s Stationery Office, 1957), 224.

79. Bridge Gray, Letter to Angus Ross, October 1, 1956, MS-2699/o28, Hocken.

8o. H.H. Thomason, H.H. Thomason to D.M. Leckie, April 4, 1978, comp. Dan Davin, MS-Papers-5079-225, ATL.

81. Bassett, “Typescript Letters of Lt Brian Bassett pt. 1," 179.

82. Angus Ross, comp., Extracts from 23 Battalion War Diary, MS-2699/o03, Hocken, 8.

83. Ross, 23 Battalion. 
84. Dan Davin, For the Rest of Our Lives (London: Michael Joseph, 1965), 15.

85. W.B. 'Sandy' Thomas, Notes and Comments with particular reference to Personal Incidents, comp. Angus Ross, MS-2699/o10, Hocken, 2.

86. Dan Davin, Letter to Winnie Davin, May 1, 1944, MS-Papers-5079-145, ATL.

87. Bassett, “Typescript Letters of Lt Brian Bassett pt. 1," 182.

88. Geoffrey Cox, Cox, Geoffrey Sandford (IWM interview), ed. Lyn Smith, Imperial War Museums interview with Geoffrey Cox (August 2004).

89. Thomas, Pathways to Adventure: An Extraordinary Life, 33.

9o. About People, Southland Times, September 2, 1918, no. 17874, 6.

91. About People, Southland Times, March 28, 1919, no. 17874, 5.

92. Lynn McConnell, Galatas 1941: Courage in Vain (Birkenhead, Auckland: Reed Publishing (NZ) Ltd, 2006), 236.

93. Davin, For the Rest of Our Lives, 216.

94. Neville Braybrooke and June Braybrooke, Olivia Manning: A Life (London: Chatto \& Windus, 2004), 137. 95. Denham, The Correspondence of Northrop Frye and Helen Kemp, 1932-1939: 1936-1939, 654.

96. Dan Davin, "Diary” (MSX-3926, ATL, 1934-1940).

97. Ross, 23 Battalion.

98. Peter Norris, Letter to Ethel May Norris, August 30, 1940, MS-2699/o11, Hocken.

99. Ian Milner, Intersecting Lines: The Memoirs of Ian Milner, ed. Vincent O'Sullivan (Wellington: Victoria University Press, 1993), 90.

100. “Marriage in England," Press, July 17, 1940, no. 23074, 2.

101. Hazel Holt, A Lot to Ask: A Life of Barbara Pym (New York: Plume, 1992), 54.

102. Angus Ross, comp., "Correspondence, mostly inward, relating to the history of the 23rd Battalion" (MS-2699/028, Hocken).

103. Brian Bassett, “Typescript Letters of Lt Brian Bassett pt. 2," ed. Joyce Bassett (MS-2702/o03, Hocken), 527. 104. Dan Davin, Letter to Winnie Davin, March 24, 1941, MS-Papers-5079-148, ATL.

105. Ovenden, A Fighting Withdrawal: The Life of Dan Davin: Writer, Soldier, Publisher, pp. 102-103.

106. Rev. M. L. Underhill, Chaplains, Official History of New Zealand in the Second World War 1939-45 (Wellington, New Zealand: War History Branch, Department Of Internal Affairs, 1950), http: //www . nzetc.vuw.ac.nz/tei-source/WH2Chap.xml.

107. Bassett, “Typescript Letters of Lt Brian Bassett pt. 1," 273.

108. Ken Armour, Letter to Angus Ross, June 20, 1954, MS-2699/o28, Hocken.

109. Douglas McEwan Leckie, Douglas McEwan Leckie to D.M. Davin, October 13, 1976, comp. Dan Davin, MS-Papers-5079-225, ATL.

110. G.W. Stonier, Mr. Eliot's New Poem, New Statesman, September 14, 1940, $267-268$.

111. Denham, The Correspondence of Northrop Frye and Helen Kemp, 1932-1939: 1936-1939, 840.

112. Deirdre David, Olivia Manning: A Woman at War (Oxford: Oxford University Press, 2013), 79.

113. Diary entry, Oxford, 10 December 1936 Davin, "Diary."

114. Richard Cobb, The End of the Line: A Memoir (London: John Murray, 1997), 99.

115. Dan Davin, Letter to Winnie Davin, October 15, 1940, MS-Papers-5079-146, ATL.

116. Ivo Elliot, ed., The Balliol College Register: Third Edition: 1900-1950 (Oxford: Charles Batey, at the University Press, 1953), 347 .

117. Thomas Fyfe, Letter to Bert [Hall], February 8, 1941, DA 56/15/9, Archives New Zealand. 
118. J. F. Cody, 28 Maori Battalion, Official History of New Zealand in the Second World War 1939-45 (Wellington: War History Branch, Department Of Internal Affairs, 1956), http: //www . nzetc . vuw . ac . nz/tei-source/WH2Maor.xml.

119. Jim Henderson, 22 Battalion, Official History of New Zealand in the Second World War 1939-45 (Wellington, New Zealand: War History Branch, Department Of Internal Affairs, 1958), http: //www .nzetc. vuw.ac.nz/tei-source/WH2-22Ba.xml.

120. Harry Dalton, Letter to Angus Ross, December 16, 1946, MS-2710/o03, Hocken.

121. Bassett, "Typescript Letters of Lt Brian Bassett pt. 1," 145.

122. Geoffrey Cox, A Tale of Two Battles: A Personal Memoir of Crete and the Western Desert 1941 (London: William Kimber, 1987), 23.

123. Henderson, 22 Battalion.

124. Dan Davin, Letter to Winnie Davin, July 21, 1940, MS-Papers-5079-148, ATL.

125. Ovenden, A Fighting Withdrawal: The Life of Dan Davin: Writer, Soldier, Publisher, 123.

126. Cox, Cox, Geoffrey Sandford (IWM interview).

127. Bassett, "Typescript Letters of Lt Brian Bassett pt. 1," 229.

128. Ovenden, A Fighting Withdrawal: The Life of Dan Davin: Writer, Soldier, Publisher, 119.

129. Ross, 23 Battalion.

130. Noel Coward, Middle East diary (London: Heinemann, 1944).

131. Thomas, Pathways to Adventure: An Extraordinary Life, 33-34.

132. Ibid., 36 .

133. M.K. Joseph, A Private Movie, MS-Papers-6678-058, ATL, 47.

134. Davin, Closing Times, 96.

135. Winnie Davin, "Memories of wartime experiences" (MS-Papers-3839, ATL).

136. Obituary: Viscount Craigavon, Southland Times, November 26, 1940, 6.

137. Davin, "Memories of wartime experiences."

138. Thomas, Pathways to Adventure: An Extraordinary Life, 38.

139. Davin, "Memories of wartime experiences."

140. B. Bassett, D.M. Davin, and W.H. McKay, eds., Men Lonely 1, no. 1 (March 1941): 26.

141. Geoffrey Cox, Road to Trieste (London: Heinemann, 1947), 143.

142. Thomas, Pathways to Adventure: An Extraordinary Life, 37.

143. Bassett, "Typescript Letters of Lt Brian Bassett pt. 1," 243.

144. D.F. Leckie, Part Two Orders: 2 Echelon 2 NZEF, MS-2699/oo3, Hocken, February 18, 1941, 5.

145. Hugh Trevor-Roper, The Wartime Journals, ed. Richard Davenport-Hines (London: I.B. Tauris \& Co Ltd, 2012), 171.

146. Philip M. Kaiser, Journeying far and wide: a political and diplomatic memoir (New York: Charles Scribner's Sons, 1992), 51.

147. Jim Henderson, Soldier Country (Wellington: GP Books, 1990), 63.

148. Simon Skinner, “Tea with Medea," London Review of Books, July 19, 2012, no. 14, 21.

149. Cited in Vernon Bogdanor, Review of My Dear Hugh: Letters from Richard Cobb to Hugh Trevor-Roper and Others, http://www.newstatesman.com/books/2011/10/hugh-letters-cobb-france-roper, New Statesman, October 31, 2011.

150. James Boswell, The Life of Samuel Johnson, ed. David Womersley (London: Penguin, 2008), 624.

151. Otto R. Frisch, "Somebody Turned the Sun on With a Switch," Science and Public Affairs: Bulletin of the Atomic Scientists 30 (4 1974): 16. 
152. Gilbert A. Harrison, Liberal Perspectives, ed. Joel Gardner, University of California, Los Angeles, 1982, 354-355, https://archive.org/details/liberalperspecti01harr.

153. Carolyn See, "The Scholars and the Pornographer," in Mentors, Muses \& Monsters: 30 Writers on the People Who Changed Their Lives, ed. Elizabeth Benedict (Albany: State University of New York Press, 2012), 143.

154. John Espey, Minor Heresies, Major Departures: A China Mission Boyhood (Berkeley: University of California Press, 1994).

155. Joseph, A Private Movie, 48.

156. Winnie Davin [W.K. Davin], “A Soldier's Wife," in Women in Wartime: New Zealand Women Tell Their Story, ed. Lauris Edmond (Wellington: Government Printing Office, 1986), 66.

157. Christopher Hurst, The View from King Street: An Essay in Autobiography (London: Thalia Press, 1997), 193.

158. James T. Sheehan, "Gordon Alexander Craig (1913-2005)," Central European History 40 (1 2007): 134.

159. Gordon Craig, Pages from a Diary: Oxford, 1976, MS-Papers-5079-491, ATL, 1976.

160. Francis Bacon, Bacon's Essays, ed. F.G. Selby (London: Macmillan \& Co., 1892), 1.

161. John Buchan, The Novel and The Fairy Tale, Pamphlet No. 79 (The English Association, 1931), 4.

162. T.S. Eliot, "Hamlet and his Problems," in The Sacred Wood: Essays on Poetry and Criticism (New York: Alfred A. Knopf, 1921), 92.

163. Vincent O'Sullivan, "On the Beach at Stresa, in 'The Wheatsheaf' in Soho," Journal of New Zealand Literature, no. 32 (2014): 22.

164. Dan Davin [D.M. Davin], Snow upon Fire: A Dance to the Music of Time : Anthony Powell : The W.D. Thomas Memorial Lecture Delivered at the College on 16th November, 1976 (Swansea: University College of Swansea, 1977).

165. Sarah Wilson and Eric de Chassey, Paris: capital of the arts, 1900-1968 (London: Royal Academy of Arts, 2002), 238.

166. Davin, "Paddy Costello," 3.

167. Ron Palenski, Men of Valour: New Zealand and the Battle for Crete (Auckland: Hachette New Zealand, 2013), 116.

168. Davin, "Paddy Costello," 2.

169. Bassett, “Typescript Letters of Lt Brian Bassett pt. 1," 264.

170. Keith A. Forsman, E.A. Forsman: priest, padre and poet 1909-1976, Unpublished manuscript distributed to libraries. (Auckland: Keith A. Forsman, 1992), 6.

171. Davin, "Paddy Costello," 1.

172. Bassett, "Typescript Letters of Lt Brian Bassett pt. 1," 264.

173. Ovenden, A Fighting Withdrawal: The Life of Dan Davin: Writer, Soldier, Publisher, 94.

174. Michael King, Letter to James McNeish, September 20, 1998, MS-Papers-8752-034, ATL.

175. Bassett, “Typescript Letters of Lt Brian Bassett pt. 1," 285.

176. Ibid., 273.

177. Dan Davin, Letter to Winnie Davin, January 13, 1941, MS-Papers-5079-148, ATL.

178. Cox, A Tale of Two Battles: A Personal Memoir of Crete and the Western Desert 1941, 27.

179. Davin, For the Rest of Our Lives, pp. 28-32.

180. Dan Davin, Letter to Winnie Davin, January 22, 1941, MS-Papers-5079-145, ATL.

181. Ibid.

182. Bassett, "Typescript Letters of Lt Brian Bassett pt. 1," 300.

183. Madeleine Barnard, Cape Town Stories (Cape Town, South Africa: Struik, 2007), 85. 
184. Harold Atcherley, Prisoner of Japan: A Personal War Diary - Singapore, Siam and Burma 1941-1945 (Cirencester: Memoirs Publishing, 2012), 51.

185. Bassett, “Typescript Letters of Lt Brian Bassett pt. 1," 297.

186. Ross, 23 Battalion.

187. Douglas Leckie, Voyage Report Jan 3. - Mar. 3 ' 4123 (Cant-Otago) Rifles, MS-2699/oo3, Hocken, March 3, 1941.

188. Ross, 23 Battalion.

189. Bassett, “Typescript Letters of Lt Brian Bassett pt. 1," 298.

190. Dan Davin, Letter to Winnie Davin, February 24, 1941, MS-Papers-5079-148, ATL.

191. Bassett, "Typescript Letters of Lt Brian Bassett pt. 1," 306-307.

192. Ibid., 309.

193. Major-General W. G. Stevens, Problems of 2 NZEF, Official History of New Zealand in the Second World War 1939-45 (Wellington, New Zealand: War History Branch, Department Of Internal Affairs, 1958), http://www.nzetc. vuw.ac.nz/tei-source/WH2Prob.xml.

194. Bernard Fergusson, Letter to William George Stevens, May 25, 1965, 84-006-1/o2, ATL.

195. Bassett, “Typescript Letters of Lt Brian Bassett pt. 1," 310.

196. Ross, Extracts from 23 Battalion War Diary.

197. Davin, Letter to Winnie Davin.

198. Elliot, The Balliol College Register: Third Edition: 1900-1950, 391.

199. Cooper, Cairo in the War: 1939-1945, 58.

200. Peter Inchbald, Jack of all trades - and his family (Lulu Press, 2013), 105.

201. Cooper, Cairo in the War: 1939-1945, 89.

202. Davin, For the Rest of Our Lives, 80.

203. Patsy Adam-Smith, The Anzacs (West Melbourne: Thomas Nelson, 1978), 54.

204. Gavin Long, To Benghazi, Australia in the War of 1939-1945: Series One: Army (Australian War Memorial, 1961), 79.

205. Ovenden, A Fighting Withdrawal: The Life of Dan Davin: Writer, Soldier, Publisher, 137.

206. Davin, For the Rest of Our Lives, 54.

207. Ross, Extracts from 23 Battalion War Diary.

208. Ibid.

209. Bassett, “Typescript Letters of Lt Brian Bassett pt. 1," 201.

210. News For Women, Press, September 26, 1933, no. 20970, 2.

211. W. G. McClymont, To Greece, Official History of New Zealand in the Second World War 1939-45 (Wellington, New Zealand: War History Branch, Department Of Internal Affairs, 1959), http: //www .nzetc. vuw.ac.nz/tei-source/WH2Gree.xml.

212. Ross, 23 Battalion.

213. Selwyn, Return to Oasis: war poems and recollections from the Middle East, 1940-1946, 247.

214. Noel Gardiner, Bringing up the Rear: The Sequel to Freyberg's Circus: Further Reminiscences of a Kiwi Soldier (Auckland: Ray Richards Publisher, 1983), 88.

215. Anthony Kenny, "Arthur Norman Prior," in Proceedings of the British Academy, vol. 56 (1970), 324.

216. Sue Onslow, "Britain and the Belgrade Coup of 27 March 1941 Revisited," Electronic Journal of International History, no. 8 (2005): 2, http://sas-space.sas.ac.uk/3395/1/Journal_of_International_ History_2005_n8_Onslow.pdf.

217. F.H. Walsh, "History of Roman Catholic Chaplains of 2NZEF" (DA 9/10/1, Archives New Zealand), 4. 218. Underhill, Chaplains. 
219. William Sheely, Letter to Mrs. C.A. Le Lievre, March 26, 1974, In private hands.

220. J. B. McKinney, Medical Units of 2 NZEF in Middle East and Italy, Official History of New Zealand in the Second World War 1939-45 (Wellington, New Zealand: War History Branch, Department Of Internal Affairs, 1952), http://www.nzetc.vuw . ac.nz/tei-source/WH2MMed.xml.

221. Sandy Thomas, Personal communication, May 8, 2015.

222. "Victory at Keren," The Sydney Morning Herald, February 29, 1941, 13, http://nla.gov . au/nla.newsarticle17728693.

223. Davin, "Paddy Costello," 1.

224. Cox, A Tale of Two Battles: A Personal Memoir of Crete and the Western Desert 1941, 32.

225. Ovid, The Metamorphoses of Ovid, trans. Michael Simpson (Amherst: University of Massachusetts Press, 2001), 15.

226. J. F. Cody, New Zealand Engineers, Middle East, Official History of New Zealand in the Second World War 1939-45 (Wellington, New Zealand: War History Branch, Department Of Internal Affairs, 1961), http://www.nzetc. vuw.ac.nz/tei-source/WH2Engr . xml.

227. Craig Stockings and Eleanor Hancock, Swastika over the Acropolis: Re-interpreting the Nazi Invasion of Greece in World War II, History of Warfare (Leiden, The Netherlands: Koninklikje Brill NV, 2013), 362.

228. Ross, 23 Battalion.

229. David Hunt, A Don at War, Revised edition with additional material, Studies in Intelligence (Frank Cass, 1990), 30.

230. Walsh, "History of Roman Catholic Chaplains of 2 NZEF," 3.

231. Ross, 23 Battalion.

232. Ibid.

233. H.H. Thomason, Brief summary of moves and actions of the 23 Bn: from 3 Jan 41 to 31 May 41: Compiled by Maj H.H. Thomason, DA 56/15/9, Archives New Zealand, 2.

234. Bassett, "Typescript Letters of Lt Brian Bassett pt. 1," 346.

235. Davin, For the Rest of Our Lives, 18.

236. Ovenden, A Fighting Withdrawal: The Life of Dan Davin: Writer, Soldier, Publisher, 21.

237. Dan Davin, Letter to Winnie Davin, February 10, 1942, MS-Papers-5079-145, ATL.

238. Davin, "Diary."

239. N.N. Sukhanov, The Russian Revolution, 1917: A Personal Record, trans. Joel Carmichael (Oxford: Oxford University Press, 1955).

240. Davin, For the Rest of Our Lives, pp 114-115.

241. Ibid., 25.

242. Ibid., 18.

243. Dan Davin, Letter to Angus Ross, October 25, 1946, MS-2699/o11, Hocken.

244. Davin, For the Rest of Our Lives, 19.

245. Bassett, "Typescript Letters of Lt Brian Bassett pt. 1," 331.

246. Ibid., 350.

247. Ibid., 351.

248. Thomason, Brief summary of moves and actions of the 23Bn: from 3 Jan 41 to 31 May 41: Compiled by Maj H.H. Thomason, 4.

249. Bassett, "Typescript Letters of Lt Brian Bassett pt. 1," 351.

250. Davin, Letter to Angus Ross.

251. Davin, For the Rest of Our Lives, pp. 22-23.

252. Davin, Letter to Angus Ross. 
253. Davin, Letter to Angus Ross.

254. Dan Davin, Letter to Winnie Davin, September 21, 1941, MS-Papers-5079-148, ATL.

255. Bassett, “Typescript Letters of Lt Brian Bassett pt. 1," 351.

256. Ross, 23 Battalion.

257. McClymont, To Greece.

258. Simpson, Operation Mercury: The Battle for Crete, 1941, 151.

259. Christopher Shores, Brian Cull, and Nicola Malizia, Air War for Yugoslavia Greece and Crete 1940-41

(London: Grub Street Publishing, 2008), 271.

260. Ibid., 272.

261. Ross, 23 Battalion.

262. Thomason, Brief summary of moves and actions of the 23 Bn: from 3 Jan 41 to 31 May 41: Compiled by Maj

H.H. Thomason, 4.

263. Davin, Letter to Angus Ross.

264. Thomas, Personal communication.

265. Ross, 23 Battalion.

266. James Hargest, Report by Brig. Hargest on Greek Ops, DA 56/15/9, Archives New Zealand, 2.

267. Obituaries, Anaesthesia 32, no. 7 (July 1977): 689.

268. Dan Davin, Letter to Winnie Davin, April 30, 1941, MS-Papers-5079-146, ATL.

269. Davin, For the Rest of Our Lives, 217.

270. Simpson, Operation Mercury: The Battle for Crete, 1941, 143.

271. Cox, A Tale of Two Battles: A Personal Memoir of Crete and the Western Desert 1941, 59.

272. "Military intelligence in 2NZEF" (DA 420.2/1, Archives New Zealand), 3.

273. Alan Henderson, David Green, and Peter Cooke, The Gunners: A History of New Zealand Artillery (Rosedale, North Shore: Penguin Books, 2008), 254.

274. Davin, For the Rest of Our Lives, 322.

275. Dan Davin [D.M. Davin], Crete, Official History of New Zealand in the Second World War 1939-45 (Wellington: War History Branch, Department Of Internal Affairs, 1953), http: //www . nzetc . vuw . ac. $\mathrm{nz} /$ tei-source/WH2Cret . xml.

276. 514 men, according to Peter William Wood, "A Battle to Win: An analysis of combat effectiveness through the Second World War experience of the 21st (Auckland) Battalion” (PhD diss., Massey University, 2012), 97.

277. Howard Kippenberger, Letter to J.L. Scoullar, January 21, 1954, WAII 11/6, Archives New Zealand.

278. Antony Beevor, Crete: The Battle and the Resistance (London: John Murray, 1991), 36.

279. Bassett, “Typescript Letters of Lt Brian Bassett pt. 1," 379.

280. The Second N.Z.E.F: Pay and Allowances, Conditions of Service, Etc. (Wellington: E.V. Paul, Government Printer, 1940), 5 .

281. McNeish, Dance of the Peacocks.

282. Ross, 23 Battalion.

283. M.E. Mulhern, Letter to Angus Ross, April 16, 1947, MS-2710/o03, Hocken.

284. Bassett, "Typescript Letters of Lt Brian Bassett pt. 1," 354.

285. M.E. Mulhern, M.E. Mulhern to Angus Ross, April 26, 1947, MS-2710/o03, Hocken.

286. L.A. Diamond, “Those Olympian Nights! - Battle in Mountains," New Zealand Free Lance, June 11, 1941, 5.

287. Bassett, “Typescript Letters of Lt Brian Bassett pt. 1,” 355. 
288. Brett Holman, The Next War in the Air: Britain's Fear of the Bomber, 1908-1941 (Farnham, Surrey: Ashgate, 2014), 57.

289. Bassett, Davin, and McKay, Men Lonely, 22.

290. “Attempted Murder Charge: Polson Before the Court: Further Remand Granted," Otago Daily Times, December 6, 1932, 2.

291. John Buchan, Homilies and Recreations (London: Thomas Nelson \& Sons, 1926), 29.

292. Dan Davin, Letter to Winnie Davin, May 10, 1941, MS-Papers-5079-146, ATL.

293. Beevor, Crete: The Battle and the Resistance, 186.

294. E Puttick, "Report on Operations in Crete: 26 Apr - 31 May 1941" (AIR 23/6571, National Archives, Kew, London, August 1, 1941), 3.

295. John Dryden, Plutarch's Lives, ed. Arthur Hugh Clough, vol. 1 (New York: Little, Brown, 1891), 4.

296. Howard Kippenberger, Infantry Brigadier (Amen House, London: Oxford University Press, 1949), http:

//www.nzetc.vuw.ac.nz/tei-source/KipInfa.xml.

297. Bassett, “Typescript Letters of Lt Brian Bassett pt. 1," 203.

298. McLeod, "The New Zealand Soldier in World War II: Myth and Reality," 85.

299. Sandy Thomas, Personal communication, September 15, 2015.

30o. Angus Ross, comp., "Additional matter from war diaries and other sources, part I" (MS-2699/o03, Hocken).

301. Davin, For the Rest of Our Lives.

302. Davin, Crete.

303. Gavin Long, Greece, Crete and Syria, Australia in the War of 1939-1945: Series One: Army (Canberra: Australian War Memorial, 1953), 330.

304. Elliot, The Balliol College Register: Third Edition: 1900-1950, 358.

305. Sagarika Ghose, “The Men Who Ruled India," Outlook, June 25, 1997, http: //www . outlookindia. com/magazine/story/the-men-who-ruled-india/203758.

306. John Tonkin-Covell, "Lieutenant General Bernard Freyberg: A Necessary Commander?," in Born to Lead? Portraits of New Zealand Commanders, ed. Glyn Harper and Joel Hayward (Auckland: Exisle Publishing, 2003), 102.

307. Ross, 23 Battalion.

308. Unit Diary 23 NZ Battalion, 23 Battalion War Diary, DA 56/15/9, Archives New Zealand, 3.

309. R.S. Stewart, "Report on Activities as RMO [Regimental Medical Officer] 23 Battalion on Crete" (DA 56/10/5, Archives New Zealand), 1.

310. Bassett, "Typescript Letters of Lt Brian Bassett pt. 2," 457.

311. Davin, Crete.

312. Dan Davin, Letter to Winnie Davin, May 30, 1941, MS-Papers-5079-146, ATL.

313. Simpson, Operation Mercury: The Battle for Crete, 1941, 171.

314. Davin, Letter to Winnie Davin.

315. G.H. Cunningham and J.B. Gray, Notes and Comments with particular reference to Personal Incidents, comp. Angus Ross, MS-2699/o10, Hocken, 4.

316. Angus Ross, comp., "Notes, extracts, correspondence and other papers mostly relating to the battle of Crete” (MS-2699/o10, Hocken).

317. L.A. Diamond, "Maoris Are Certainly the Goods with Cold Steel," New Zealand Free Lance, July 23, 1941, 5 .

318. 23 NZ Battalion, "Unit Historical Records - Summary of Moves and Actions - Unit Diary, Miscellaneous reports etc" (DA 56/15/9, Archives New Zealand). 
319. Stewart, "Report on Activities as RMO [Regimental Medical Officer] 23 Battalion on Crete," 2.

320. Davin, Letter to Winnie Davin.

321. T. Duncan M. Stout, New Zealand Medical Services in Middle East and Italy, Official History of New Zealand in the Second World War 1939-45 (Wellington, New Zealand: War History Branch, Department Of Internal Affairs, 1956), http://www.nzetc.vuw. ac.nz/tei-source/WH2Medi.xml. 322. Ibid.

323. Cody, New Zealand Engineers, Middle East.

324. Davin, Crete.

325. Ibid.

326. Puttick, "Report on Operations in Crete: 26 Apr - 31 May 1941," 12.

327. I.S.O Playfair et al., The Mediterranean and the Middle East, Volume 2: The Germans Come to the Help of their Ally, 1941, ed. James Butler, History of the Second World War: United Kingdom Military Series (London: Her Majesty's Stationery Office, 1956), 135.

328. Puttick, "Report on Operations in Crete: 26 Apr - 31 May 1941," 11.

329. Robin Kay, 27 (Machine Gun) Battalion, Official History of New Zealand in the Second World War 1939-45 (Wellington, New Zealand: War History Branch, Department Of Internal Affairs, 1958), http: //www.nzetc. vuw.ac.nz/tei-source/WH2-27Ba.xml.

330. R M Bell, "Notes on the air borne invasion of Crete" (DA 21/13/3, Archives New Zealand).

331. Cody, 28 Maori Battalion.

332. Puttick, "Report on Operations in Crete: 26 Apr - 31 May 1941," 8.

333. Stout, New Zealand Medical Services in Middle East and Italy.

334. Davin, Crete.

335. Davin, The Salamander and the Fire: Collected War Stories, 19.

336. John Willett, Letter to Dan Davin, MS-Papers-5079-056, ATL, June 22, 1966.

337. Diary entry for 11 May 1944; For the Rest of Our Lives pp. 351-352.

338. Diary entry for 3 August 1944.

339. Bassett, "Typescript Letters of Lt Brian Bassett pt. 1," 351.

340. William Blake, "Milton: A Poem in 2 Books," in Complete Writings: With All The Variant Readings, ed. Geoffrey Keynes (London: Oxford University Press, 1969), 518.

341. Janet Wilson, "Dan Davin: The Literary Legacy of War," in Scholars at War: Australasian Social Scientists, 1939-1945, ed. Geoffrey Gray, Doug Munro, and Christine Winter (Canberra: Australian National University E Press, 2012), 237.

342. W.G. Stevens, Freyberg, V.C. the man, 1939-1945 (London \& Wellington: Herbert Jenkins \& A.H. \& A.W. Reed, 1965), 96.

343. Davin, The Salamander and the Fire: Collected War Stories, 177.

344. Diary entry for 26 April 1943.

345. Diary entry for 20 November 1942.

346. Diary entry for 25 June 1943.

347. Diary entry for June 81944.

348. Diary entry for 14 June 1941.

349. Diary entry for 13 March 1944

350. Ibid., 119-120.

351. Ibid., 131. 


\section{Bibliography}

\section{Unpublished Sources}

23 NZ Battalion. 23 Battalion War Diary. DA 56/15/9, Archives New Zealand.

—. "Unit Historical Records - Summary of Moves and Actions - Unit Diary, Miscellaneous reports etc.” DA 56/15/9, Archives New Zealand.

Allen, C.K. Warden of Rhodes House Report. Davin File, Rhodes Trust Archives, Rhodes House, 1936/37.

Armour, Ken. Letter to Angus Ross, June 20, 1954. MS-2699/o28, Hocken.

Auchinleck, J. Letter to Bernard Freyberg, February 2, 1942. WAII8 4, Archives New Zealand.

Bassett, Brian. “Typescript Letters of Lt Brian Bassett pt. 1.” Edited by Joyce Bassett. MS-2702/002, Hocken.

— . "Typescript Letters of Lt Brian Bassett pt. 2." Edited by Joyce Bassett. MS2702/o03, Hocken.

Bell, R M. "Notes on the air borne invasion of Crete." DA 21/13/3, Archives New Zealand.

Bell, Rachel Elizabeth. "Memory, History, Nation, War: The Official Histories of New Zealand in the Second World War 1939-1945." PhD diss., Massey University, 2012.

Bell, R.W. “Intelligence at a Divisional Headquarters." DA 21.1/10/8, Archives New Zealand.

Bertram, James, comp. “Letters from Dan Davin.” 93-133-30, ATL.

Catley, Jenny. Personal communication, July 28, 2015.

"Citations for medals awarded during the Crete campaign." MS-Papers-5079-362, ATL.

Clark, John. Letter to Angus Ross, November 26, 1946. MS-2702/o05, Hocken. 
“Correspondence - Geoffrey Flavell." MS-Papers-5079-019, ATL.

Costello, Paddy. Diary. Private hands.

Cox, Geoffrey. Cox, Geoffrey Sandford (IWM interview). Edited by Lyn Smith. Imperial War Museums interview with Geoffrey Cox. August 2004.

—. "History of Military Intelligence in the 2NZEF." 2003-005-3/15, ATL.

— comp. "Scrapbook on his war years." MSY-5579, ATL, 1940-1945.

Craig, Gordon. Pages from a Diary: Oxford, 1976. MS-Papers-5079-491, ATL, 1976.

Cunningham, G.H., and J.B. Gray. Notes and Comments with particular reference to Personal Incidents. Compiled by Angus Ross. MS-2699/o10, Hocken.

Dalton, Harry. Letter to Angus Ross, December 16, 1946. MS-2710/o03, Hocken.

Davin, Dan, comp. “Correspondence relating to military topics.” MS-Papers-5079-225, ATL.

—. "Diary." MSX-3926, ATL, 1934-1940.

—. Letter to Angus Ross, October 25, 1946. MS-2699/o11, Hocken.

. Letter to C.K. Allen, December 26, 1941. Davin File, Rhodes Trust Archives, Rhodes House.

Letter to C.K. Allen, August 5, 1944. Davin File, Rhodes Trust Archives, Rhodes House.

—. Letter to Dick Hughes, July 31, 1983. MS-Papers-5079-426, ATL.

—. Letter to Geoff Flavell, March 29, 1979. MS-Papers-5079-019, ATL.

. Letter to Howard Kippenberger, January 4, 1949. IAI 181/32/2, National Archives, Kew, London.

—. Letter to James Bertram, March 6, 1982. 93-133-30, ATL.

—. Letter to James Bertram, March 30, 1982. 93-133-30, ATL.

- Letter to Laurie Nathan, October 11, 1982. MS-Papers-5079-426, ATL.

—. Letter to William George Stevens, March 4, 1966. 84-006-1/o2, ATL.

- Letter to Winnie Davin, October 15, 1940. MS-Papers-5079-146, ATL.

- Letter to Winnie Davin, July 21, 1940. MS-Papers-5079-148, ATL.

—. Letter to Winnie Davin, March 24, 1941. MS-Papers-5079-148, ATL. 
Davin, Dan. Letter to Winnie Davin, January 13, 1941. MS-Papers-5079-148, ATL.

—. Letter to Winnie Davin, January 22, 1941. MS-Papers-5079-145, ATL.

—. Letter to Winnie Davin, February 24, 1941. MS-Papers-5079-148, ATL.

—. Letter to Winnie Davin, September 21, 1941. MS-Papers-5079-148, ATL.

—. Letter to Winnie Davin, April 30, 1941. MS-Papers-5079-146, ATL.

—. Letter to Winnie Davin, May 10, 1941. MS-Papers-5079-146, ATL.

—. Letter to Winnie Davin, May 30, 1941. MS-Papers-5079-146, ATL.

—. Letter to Winnie Davin, February 10, 1942. MS-Papers-5079-145, ATL.

—. Letter to Winnie Davin, May 1, 1944. MS-Papers-5079-145, ATL.

__ "Letters to Winifred Davin.” MS-Papers-5079-146, ATL.

__. "Letters to Winifred Davin.” MS-Papers-5079-145, ATL.

_ . "Letters to Winifred Davin." MS-Papers-5079-148, ATL.

—. "Paddy Costello." MS-Papers-5079-435, ATL, 1982.

— , comp. “Papers relating to Paddy Costello.” MS-Papers-5079-426, ATL.

. The Battle of Crete. Script of BBC programme produced by Leonard Cottrell, broadcast 22 July 1951. MS-Papers-5079-338, ATL, 1951.

Davin, Winnie. "Memories of wartime experiences.” MS-Papers-3839, ATL.

Ewart, J.O. Letter to Geoffrey Cox, July 24, 1942. 2003-005-5/13, ATL.

Fathers, Michael. Sir Geoffrey Cox Material. MSDL-0359, ATL, 2006.

Fergusson, Bernard. Letter to William George Stevens, May 25, 1965. 84-006-1/o2, ATL.

Flavell, Geoff. Letter to Dan Davin, February 2, 1986. MS-Papers-5079-019, ATL.

Freyberg, Bernard. Telegram to Peter Fraser, November 6, 1941. DA 1/9/5/3, Archives New Zealand.

Fyfe, Thomas. Letter to Bert [Hall], February 8, 1941. DA 56/15/9, Archives New Zealand.

Gray, Bridge. Letter to Angus Ross, October 1, 1956. MS-2699/o28, Hocken.

Hargest, James. Report by Brig. Hargest on Greek Ops. DA 56/15/9, Archives New Zealand.

Harper, Glyn John. "Kip. Major General Sir Howard Kippenberger, KBE, CB, DSO and Bar, ED: A Study of Command.” PhD diss., University of New England, 1996. 
Harrison, Gilbert A. Liberal Perspectives. Edited by Joel Gardner. University of California, Los Angeles, 1982. https : //archive .org/details/liberalperspecti01harr. Jeavons, Alf. Letter to John Clark, June 24, 1946. MS-2699/o28, Hocken. Joseph, M.K. A Private Movie. MS-Papers-6678-058, ATL.

—. Old Sacred Heart College, 1927-30. MS-Papers-6678-058, ATL.

_. "Travel diary." MSX-7471, ATL.

King, Michael. Letter to James McNeish, August 31, 1998. MS-Papers-8752-034, ATL.

—. Letter to James McNeish, September 20, 1998. MS-Papers-8752-034, ATL.

—. Letter to Winnie Davin, November 7, 1990. MS-Papers-8752-034, ATL.

_. "Personal Papers.” MS-Papers-8752-034, ATL.

King, Rachel. Personal communication, July 1, 2015.

Kippenberger, Howard. Letter to Angus Ross, December 16, 1946. MS-2702/o05, Hocken.

—. Letter to Angus Ross, July 2, 1954. MS-2699/o28, Hocken.

—. Letter to J.L. Scoullar, July 17, 1951. WAII 11/6, Archives New Zealand.

—. Letter to J.L. Scoullar, January 21, 1954. WAII 11/6, Archives New Zealand.

Kitteridge, Rebecca. Personal communication, May 29, 2015.

Leckie, D.F. Part Two Orders: 2 Echelon 2NZEF. MS-2699/oo3, Hocken, February 18, 1941.

Leckie, Douglas. Voyage Report Jan 3. - Mar. 3 ' 4123 (Cant-Otago) Rifles. MS-2699/oo3, Hocken, March 3, 1941.

Leckie, Douglas McEwan. Douglas McEwan Leckie to D.M. Davin, October 13, 1976. Compiled by Dan Davin. MS-Papers-5079-225, ATL.

Malcolm, M.A.J. Letter to NZ Mil HQ (UK), January 29, 1945. A200/D5, Archives New Zealand.

McCormick, Eric, comp. Dan's Funeral: 1.10.199o. MS-Papers-5292-013, ATL, 1990.

McLeod, John Reginald. “The New Zealand Soldier in World War II: Myth and Reality.” Master's thesis, Massey University, 1980.

“Military intelligence in 2NZEF." DA 420.2/1, Archives New Zealand.

Mulhern, M.E. Letter to Angus Ross, April 16, 1947. MS-2710/o03, Hocken. 
Mulhern, M.E. M.E. Mulhern to Angus Ross, April 26, 1947. MS-2710/o03, Hocken.

Norris, Peter. Letter to Ethel May Norris, August 30, 1940. MS-2699/o11, Hocken.

Letter to Family, April 28, 1942. MS-2699/o11, Hocken.

Puttick, E. "Report on Operations in Crete: 26 Apr - 31 May 1941." AIR 23/6571, National Archives, Kew, London, August 1, 1941.

Rhodes Trust, comp. Davin File, Rhodes Trust Archives, Rhodes House.

Ross, Angus, comp. "Additional matter from war diaries and other sources, part I." MS-2699/oo3, Hocken.

— , comp. "Correspondence, mostly inward, relating to the history of the 23rd Battalion.” MS-2699/o28, Hocken.

— , comp. "Correspondence relating to the unit history of the 23rd Battalion." MS-2702/005, Hocken.

— , comp. "Correspondence, typescript chapters, photographs and other papers relating to the unit history of the 23rd Battalion." MS-2710/o03, Hocken.

—, comp. Extracts from 23 Battalion War Diary. MS-2699/o03, Hocken.

— , comp. "Extracts from diaries, letters and official records, reminiscences, notes and other papers mostly relating to Greece and Crete." MS-2699/o11, Hocken.

—. Letter to Doug Leckie, February 4, 1947. MS-2702/005, Hocken.

—. Letter to John Clark, June 15, 1946. MS-2699/o28, Hocken.

— comp. "Notes, extracts, correspondence and other papers mostly relating to the battle of Crete." MS-2699/o10, Hocken.

Sheely, William. Letter to Mrs. C.A. Le Lievre, March 26, 1974. In private hands.

Stevens, William George, comp. "Correspondence - D to F." 84-006-1/02, ATL.

Stewart, R.S. "Report on Activities as RMO [Regimental Medical Officer] 23 Battalion on Crete." DA 56/10/5, Archives New Zealand.

Thomas, Sandy. Personal communication, May 8, 2015.

Personal communication, September 15, 2015.

Thomas, W.B. 'Sandy'. Notes and Comments with particular reference to Personal Incidents. Compiled by Angus Ross. MS-2699/o10, Hocken. 
Thomason, H.H. Brief summary of moves and actions of the 23Bn: from 3 Jan 41 to 31 May 41: Compiled by Maj H.H. Thomason. DA 56/15/9, Archives New Zealand.

. H.H. Thomason to D.M. Leckie, April 4, 1978. Compiled by Dan Davin. MSPapers-5079-225, ATL.

Walker, Geoff. Letter to Michael King, April 5, 2000. MS-Papers-8752-034, ATL.

Personal communication, July 1, 2015.

Walsh, F.H. "History of Roman Catholic Chaplains of 2NZEF." DA 9/10/1, Archives New Zealand.

Willett, John. Letter to Dan Davin. MS-Papers-5079-056, ATL, June 22, 1966.

Wood, Peter William. "A Battle to Win: An analysis of combat effectiveness through the Second World War experience of the 21st (Auckland) Battalion." PhD diss., Massey University, 2012.

\section{Published Sources}

Adam-Smith, Patsy. The Anzacs. West Melbourne: Thomas Nelson, 1978.

Obituaries. Anaesthesia 32, no. 7 (July 1977): 689.

Atcherley, Harold. Prisoner of Japan: A Personal War Diary - Singapore, Siam and Burma 1941-1945. Cirencester: Memoirs Publishing, 2012.

Bacon, Francis. Bacon's Essays. Edited by F.G. Selby. London: Macmillan \& Co., 1892.

Barnard, Madeleine. Cape Town Stories. Cape Town, South Africa: Struik, 2007.

Bassett, B., D.M. Davin, and W.H. McKay, eds. Men Lonely 1, no. 1 (March 1941).

Beevor, Antony. Crete: The Battle and the Resistance. London: John Murray, 1991.

Bertram, James. Dan Davin. New Zealand Writers and Their Work. Auckland: Oxford University Press, 1983.

Blake, William. "Milton: A Poem in 2 Books." In Complete Writings: With All The Variant Readings, edited by Geoffrey Keynes, 480-535. London: Oxford University Press, 1969.

Bogdanor, Vernon. Review of My Dear Hugh: Letters from Richard Cobb to Hugh TrevorRoper and Others. http://www. newstatesman. com/books/2011/10/hughletters-cobb-france-roper, New Statesman, October 31, 2011. 
Boswell, James. The Life of Samuel Johnson. Edited by David Womersley. London: Penguin, 2008.

Braybrooke, Neville, and June Braybrooke. Olivia Manning: A Life. London: Chatto \& Windus, 2004.

Buchan, John. Homilies and Recreations. London: Thomas Nelson \& Sons, 1926.

—. The Novel and The Fairy Tale. Pamphlet No. 79. The English Association, 1931.

Cobb, Richard. The End of the Line: A Memoir. London: John Murray, 1997.

Cody, J. F. 28 Maori Battalion. Official History of New Zealand in the Second World War 1939-45. Wellington: War History Branch, Department Of Internal Affairs, 1956. http://www.nzetc.vuw.ac.nz/tei-source/WH2Maor.xml.

. New Zealand Engineers, Middle East. Official History of New Zealand in the Second World War 1939-45. Wellington, New Zealand: War History Branch, Department Of Internal Affairs, 1961. http: //www.nzetc. vuw . ac.nz/teisource/WH2Engr.xml.

Collier, Basil. The Defense of the United Kingdom. Edited by J.R.M Butler. History of the Second World War: United Kingdom Military Series. London: Her Majesty's Stationery Office, 1957.

Cooper, Artemis. Cairo in the War: 1939-1945. London: Penguin Books, 1989.

Coward, Noel. Middle East diary. London: Heinemann, 1944.

Cox, Geoffrey. A Tale of Two Battles: A Personal Memoir of Crete and the Western Desert 1941. London: William Kimber, 1987.

Road to Trieste. London: Heinemann, 1947.

David, Deirdre. Olivia Manning: A Woman at War. Oxford: Oxford University Press, 2013.

Davin, Dan. Closing Times. London: Faber \& Faber, 2010.

[D.M. Davin]. Crete. Official History of New Zealand in the Second World War 1939-45. Wellington: War History Branch, Department Of Internal Affairs, 1953. http://www.nzetc.vuw.ac.nz/tei-source/WH2Cret.xml.

. For the Rest of Our Lives. London: Michael Joseph, 1965.

Norman Davis: The Growth of a Scholar. Edited by Douglas Gray and E.G. Stanley. An Offprint from Middle English Studies presented to NORMAN DAVIS in Honour of his Seventieth Birthday. Oxford: Clarendon Press, 1983. 
Davin, Dan [D.M. Davin]. Snow upon Fire: A Dance to the Music of Time : Anthony Powell: The W.D. Thomas Memorial Lecture Delivered at the College on 16th November, 1976. Swansea: University College of Swansea, 1977.

The Salamander and the Fire: Collected War Stories. Auckland: Oxford University Press, 1986.

. “Three Encounters Thirty Years Ago." Islands, no. 21 (March 1978): 302-306.

Davin, Winnie [W.K. Davin]. “A Soldier's Wife.” In Women in Wartime: New Zealand Women Tell Their Story, edited by Lauris Edmond, 65-75. Wellington: Government Printing Office, 1986.

Denham, Robert D., ed. The Correspondence of Northrop Frye and Helen Kemp, 19321939: 1936-1939. Toronto University Press, 1996.

Diamond, L.A. "Maoris Are Certainly the Goods with Cold Steel." New Zealand Free Lance, July 23, 1941.

_. "Those Olympian Nights! - Battle in Mountains." New Zealand Free Lance, June 11, 1941, 5 .

Dryden, John. Plutarch's Lives. Edited by Arthur Hugh Clough. Vol. 1. New York: Little, Brown, 1891.

Eliot, T.S. "Hamlet and his Problems." In The Sacred Wood: Essays on Poetry and Criticism, 87-95. New York: Alfred A. Knopf, 1921.

Elliot, Ivo, ed. The Balliol College Register: Third Edition: 1900-1950. Oxford: Charles Batey, at the University Press, 1953.

Espey, John. Minor Heresies, Major Departures: A China Mission Boyhood. Berkeley: University of California Press, 1994.

Forsman, Keith A. E.A. Forsman: priest, padre and poet 1909-1976. Unpublished manuscript distributed to libraries. Auckland: Keith A. Forsman, 1992.

Frisch, Otto R. "Somebody Turned the Sun on With a Switch." Science and Public Affairs: Bulletin of the Atomic Scientists 30 (4 1974): 13-18.

Gardiner, Noel. Bringing up the Rear: The Sequel to Freyberg's Circus: Further Reminiscences of a Kiwi Soldier. Auckland: Ray Richards Publisher, 1983.

Ghose, Sagarika. “The Men Who Ruled India.” Outlook, June 25, 1997. http : / / www . outlookindia.com/magazine/story/the-men-who-ruled-india/ 203758. 
Henderson, Alan, David Green, and Peter Cooke. The Gunners: A History of New Zealand Artillery. Rosedale, North Shore: Penguin Books, 2008.

Henderson, Jim. 22 Battalion. Official History of New Zealand in the Second World War 1939-45. Wellington, New Zealand: War History Branch, Department Of Internal Affairs, 1958. http://www.nzetc.vuw.ac.nz/tei-source/WH2-22Ba.xml. . Soldier Country. Wellington: GP Books, 1990.

Holman, Brett. The Next War in the Air: Britain's Fear of the Bomber, 1908-1941. Farnham, Surrey: Ashgate, 2014.

Holt, Hazel. A Lot to Ask: A Life of Barbara Pym. New York: Plume, 1992.

Hunt, David. A Don at War. Revised edition with additional material. Studies in Intelligence. Frank Cass, 1990.

Hurst, Christopher. The View from King Street: An Essay in Autobiography. London: Thalia Press, 1997.

Inchbald, Peter. Jack of all trades - and his family. Lulu Press, 2013.

Kaiser, Philip M. Journeying far and wide: a political and diplomatic memoir. New York: Charles Scribner's Sons, 1992.

Kay, Robin. 27 (Machine Gun) Battalion. Official History of New Zealand in the Second World War 1939-45. Wellington, New Zealand: War History Branch, Department Of Internal Affairs, 1958. http://www.nzetc.vuw.ac.nz/tei-source/WH2$27 \mathrm{Ba} . \mathrm{xml}$.

Kenny, Anthony. "Arthur Norman Prior." In Proceedings of the British Academy, 56:321349. 1970.

Kippenberger, Howard. Infantry Brigadier. Amen House, London: Oxford University Press, 1949. http://www.nzetc.vuw .ac.nz/tei-source/KipInfa.xml.

Kisch, Richard. The Days of the Good Soldiers: Communists in the Armed Forces WWII. London: Journeyman, 1985.

Long, Gavin. Greece, Crete and Syria. Australia in the War of 1939-1945: Series One: Army. Canberra: Australian War Memorial, 1953.

. To Benghazi. Australia in the War of 1939-1945: Series One: Army. Australian War Memorial, 1961.

McClymont, W. G. To Greece. Official History of New Zealand in the Second World War 1939-45. Wellington, New Zealand: War History Branch, Department Of Internal Affairs, 1959. http://www.nzetc. vuw.ac.nz/tei-source/WH2Gree.xml. 
McConnell, Lynn. Galatas 1941: Courage in Vain. Birkenhead, Auckland: Reed Publishing (NZ) Ltd, 2006.

McKinney, J. B. Medical Units of 2 NZEF in Middle East and Italy. Official History of New Zealand in the Second World War 1939-45. Wellington, New Zealand: War History Branch, Department Of Internal Affairs, 1952. http: //www . nzetc. vuw . ac.nz/tei-source/WH2MMed.xml.

McNeish, James. Dance of the Peacocks. Auckland: Vintage, 2003.

Milner, Ian. Intersecting Lines: The Memoirs of Ian Milner. Edited by Vincent O'Sullivan. Wellington: Victoria University Press, 1993.

New Zealand Herald. "Soldier M.P.: Death on Service: Lieutenant Hultquist: Illness While on Leave." November 5, 1941, no. 24114, 6.

Onslow, Sue. "Britain and the Belgrade Coup of 27 March 1941 Revisited." Electronic Journal of International History, no. 8 (2005). http://sas-space. sas . ac . uk/ 3395/1/Journal_of_International_History_2005_n8_Onslow.pdf.

O'Sullivan, Vincent. "On the Beach at Stresa, in 'The Wheatsheaf' in Soho." Journal of New Zealand Literature, no. 32 (2014): 11-30.

Otago Daily Times. "Attempted Murder Charge: Polson Before the Court: Further Remand Granted." December 6, 1932, 2.

Ovenden, Keith. A Fighting Withdrawal: The Life of Dan Davin: Writer, Soldier, Publisher. Oxford: Oxford University Press, 1996.

"Davin, Dan." In The Oxford Companion to New Zealand Literature, edited by Roger Robinson and Nelson Wattie. Melbourne: Oxford University Press, 1998.

Ovid. The Metamorphoses of Ovid. Translated by Michael Simpson. Amherst: University of Massachusetts Press, 2001.

Palenski, Ron. Men of Valour: New Zealand and the Battle for Crete. Auckland: Hachette New Zealand, 2013.

Perrault, Gilles. "Henri Curiel, citizen of the third world." https : //mondediplo. com/1998/04/13curiel, Le Monde Diplomatique, April 1998.

Perraut, Giles. A Man Apart: The Life of Henry Curiel. Translated by Bob Cumming. London: Zed Books Ltd, 1987. 
Playfair, I.S.O, F.C. Flynn, C.J.C. Molony, and S.E. Toomer. The Mediterranean and the Middle East, Volume 2: The Germans Come to the Help of their Ally, 1941. Edited by James Butler. History of the Second World War: United Kingdom Military Series. London: Her Majesty's Stationery Office, 1956.

Press. "Marriage in England." July 17, 1940, no. 23074, 2.

. News For Women. September 26, 1933, no. 20970, 2.

Ross, Angus. 23 Battalion. Official History of New Zealand in the Second World War 1939-45. Wellington, New Zealand: War History Branch, Department Of Internal Affairs, 1959. http://www.nzetc. vuw. ac.nz/tei-source/WH2-23Ba.xml.

See, Carolyn. “The Scholars and the Pornographer.” In Mentors, Muses \& Monsters: 30 Writers on the People Who Changed Their Lives, edited by Elizabeth Benedict, 138-146. Albany: State University of New York Press, 2012.

Selwyn, Victor, ed. Return to Oasis: war poems and recollections from the Middle East, 1940-1946. London: Shepheard-Walwyn for Poetry Editions London for the Salamander Oasis Trust, 1980.

Sheehan, James T. “Gordon Alexander Craig (1913-2005)." Central European History 40 (1 2007): 133-137.

Shores, Christopher, Brian Cull, and Nicola Malizia. Air War for Yugoslavia Greece and Crete 1940-41. London: Grub Street Publishing, 2008.

Simpson, Tony. Operation Mercury: The Battle for Crete, 1941. London: Hodder \& Stoughton, 1981.

Skinner, Simon. “Tea with Medea.” London Review of Books, July 19, 2012, no. 14, 21-22.

Southland Times. About People. September 2, 1918, no. 17874, 6.

About People. March 28, 1919, no. 17874, 5.

Obituary: Viscount Craigavon. November 26, 1940, 6.

Stevens, Major-General W. G. Problems of 2 NZEF. Official History of New Zealand in the Second World War 1939-45. Wellington, New Zealand: War History Branch, Department Of Internal Affairs, 1958. http://www.nzetc. vuw. ac.nz/teisource/WH2Prob.xml.

Stevens, W.G. Freyberg, V.C. the man, 1939-1945. London \& Wellington: Herbert Jenkins \& A.H. \& A.W. Reed, 1965. 
Stockings, Craig, and Eleanor Hancock. Swastika over the Acropolis: Re-interpreting the Nazi Invasion of Greece in World War II. History of Warfare. Leiden, The Netherlands: Koninklikje Brill NV, 2013.

Stonier, G.W. Mr. Eliot's New Poem. New Statesman, September 14, 1940, 267-268.

Stout, T. Duncan M. New Zealand Medical Services in Middle East and Italy. Official History of New Zealand in the Second World War 1939-45. Wellington, New Zealand: War History Branch, Department Of Internal Affairs, 1956. http : // www.nzetc.vuw.ac.nz/tei-source/WH2Medi.xml.

Sukhanov, N.N. The Russian Revolution, 1917: A Personal Record. Translated by Joel Carmichael. Oxford: Oxford University Press, 1955.

The Second N.Z.E.F: Pay and Allowances, Conditions of Service, Etc. Wellington: E.V. Paul, Government Printer, 1940.

The Sydney Morning Herald. "Victory at Keren." February 29, 1941, 13. http: //nla. gov.au/nla.news-article17728693.

Thomas, W.B. 'Sandy'. Pathways to Adventure: An Extraordinary Life. Edited by Denis McLean. Terrace Station, Hororata: Dryden Press, 2004.

Tonkin-Covell, John. "Lieutenant General Bernard Freyberg: A Necessary Commander?" In Born to Lead? Portraits of New Zealand Commanders, edited by Glyn Harper and Joel Hayward, 97-120. Auckland: Exisle Publishing, 2003.

Trevor-Roper, Hugh. The Wartime Journals. Edited by Richard Davenport-Hines. London: I.B. Tauris \& Co Ltd, 2012.

Underhill, Rev. M. L. Chaplains. Official History of New Zealand in the Second World War 1939-45. Wellington, New Zealand: War History Branch, Department Of Internal Affairs, 1950. http://www.nzetc.vuw .ac.nz/tei-source/WH2Chap. xml.

Wilson, Janet. “Dan Davin: The Literary Legacy of War.” In Scholars at War: Australasian Social Scientists, 1939-1945, edited by Geoffrey Gray, Doug Munro, and Christine Winter, 225-241. Canberra: Australian National University E Press, 2012.

— - ed. Intimate Stranger: Reminiscences of Dan Davin. Wellington: Steele Roberts, 2000 .

Wilson, Sarah, and Eric de Chassey. Paris: capital of the arts, 1900-1968. London: Royal Academy of Arts, 2002.

Wynn, Kenneth G. Men of the Battle of Britain: A Biographical Dictionary of the Few. Barnsley, S. Yorkshire: Frontline Books, 2015. 


\section{Index}

A

Abu'l Huda, Velia 'Lulie', 63, 64 Allen, Carleton Kemp 'CK', 36n, 36 Allen, Stephen Shepherd, 109 Arms, Henry Shull, 38, 40-42 Arms, Nancy 'Nan', 40-42 Ashby, Alexander Quin, 7

B

Bacon, Francis, 44n

Bacon, Margaret Frances 'Peggy', $37 n$

Baird, Mollie, 8o

Baldwin, Stanley, 101n

Barton, Philip Treherne, 64

Bassett, Brian Irvin, 4n, 23n, 25, 31, 34, $35 n, 50,51 n, 55,56,57 n, 62,87$, $88 n, 92,99 n, 101 n, 106,107$

Baudelaire, Charles Pierre, $12 n$

Baxter, Bruce York Warner, 2, 114, 115, 118

Beck, Leslie, 36, 37

Beck, Ursula, 37

Bell, Robert Moore 'Robin', $96 n$

Bevin, James Arthur 'Jim', 110n, 118

Birtwistle, Jack Harrison, 113

Black, Herbert Charles 'Herbie', 101

Bleakly, Maurice Cameron, 37

Bond, Robert Louis 'Bruff', 10, 35, 75, 79, 101

Bordeaux, Henri, 34

Borrow, George Henry, 34

Boswell, James, $38 n$
Brant, Percy Anthony Matthew

'Peter', 117, 118

Braun, Martin, 84

Brook, John Edward 'Shorty', 101

Browning, Robert, $51 n$

Buchan, John, 44n, 104

Burnett, Nance Wilson, 65, 109

\section{C}

Caldwell, Edward, 73, 109

Campbell, Paul Vincent, 88

Carmichael, Joel, 84

Carpenter, Jack Conway, $1 n$

Chamberlain, Arthur Neville, 29

Chard, Charles Lambton, 114

Chekhov, Anton Pavlovich, 6n, $12 n$

Churchill, Winston, 59n, 101n

Cobb, Richard Charles, 37-43

Connolly, Joseph Richard John

'Dick', 10, 20, 26-28, 90

Costello, Desmond Patrick 'Paddy', 74, 100

Cotterall, Robert Charlton

'Ponsonby', 29

Cox, Geoffrey, 6n, 23n, 46, 53n, 60, 63, 96, 100, 109

Craig, James, 31

Crawford, Archibald 'Archie', 67, 71

Cunningham, Gordon Hallum

'Ginger', 10, 26, 35, 54, 58, 63 , $68,69,72,74,75,79,105$ 
D

D’Annunzio, Gabriele, 97

d'Orleans, Charles, 29

Dalton, Thomas Robert, 89

Dalton, William Henry 'Harry', 112

Davin, Anna Deirdre, 1, 5, 11-13, 17, 21, $23,24,27,28,30,33,47,49$, $60,64,79,105,106,116$

Davin, Martin 'Matt', 11

Davin, Mary Magdalene, 6

Davin, Patrick, 80

Davin, Thomas Patrick 'Tom', 64

Davin, Winifred Kathleen 'Winnie', 1, $3,5,6,9,12,13,15,17-24$, $26-31,33-35,42,43,46-49,56$, $60,62-64,72,73,79,81,82,85$, $87,94,97,104-106,109,116$

Dawson, Robert Boyd, $85 n$

de Balzac, Honoré, 30 n

de Clive Lowe, Selwyn Grahame, 92, 115

de La Fontaine, Jean, $97 n$

de Maupassant, Guy, 43n, $95 n$

Diamond, Leonard Alfred, 101n, 114n

Dittmer, George, 55n

Dittmer, George Frederick, 55, 100

Dreiser, Theodore Herman Albert, $8 n$

Drummond, Robert John Heugh

'Bulldog', 41, 47, 84

Duke of Gloucester, Henry, 35

Dutton, Charles Horace, 5, 81, 87, 88n, 103, 106, 112

Dutton, Garth Ainsworth, 100

E

Edwards, William Anzac, 100

Einstein, Albert, $85 n$

Eliot, Thomas Stearns, 12n, 40n, 44n, $94 n$

Ensor, James Hugh 'Jim', 10, 54

Espey, John Jenkins, 39
Evans, Stanley Clarence 'Ginger', 5, 35, $47,54,71,81,83,85,103,104$, 106, 109-112

F

Falconer, Alexander Smith 'Acky', $4 n$, 20, 21, 58, 62n, 62, 106, 109

Farson, James Negley, 61

Finnerty, James Edward, 108

Fisher, Thomas Joseph, 88

Fisher, Vardis Alvero, 79

Flaubert, Gustave, 45n

Flavell, Geoffrey, 11, 26, 27, 29, 30 n, 46

Fletcher, Frederick, 108

Fonda, Henry, $16 n$

Forrester, Michael, $99 n$

Forsman, Edward Archibald

'Ted', 50-52, 54, 55, 60n, 74n

Foster, Rayfield Charles, 110, 112

Fouquet, Jean, $46 n$

Fowler, Ashley Edward, 25

France, Anatole, 105, 106n

Freud, Sigmund, 74n, 85n

Freyberg, Bernard Cyril 'Tiny', 62, 93, 99, 109, 110 n

Fry, Edith May, $24 n$

Frye, Northrop, $8 n$

Fyfe, Thomas 'Tommy', 13, 33, 55, 92, 108, 109, 112

\section{G}

Galilei, Galileo, 85n

Garrett, John Charles 'Jack', 84

Gerhardi, William Alexander, 8

Ghiselin, Richard Sommerville

'Dick', 37-40

Ginger, see Evans, Stanley Clarence 'Ginger'

Gluckman, Jonathon 'Jon', 26

Gluckman, Judith, 26n

Golay, John Ford 'Jack', 38, 39

Golding, Louis, 51 
Gonley, John Joseph 'Jack', 106

Graham, Malise Lynedoch de la

Trémouille Moray, 17

Gray, James Bridgeman 'Bridge', 2, $113 n$

Greig, Leslie Alexander 'Les', 17, 106

Grey, Pearl Zane, 102

Griffiths, Robert John 'Bob', 114

H

Hanson, Frederick Melrose

Horowhenua 'Bull', 93

Harcourt, Robert Maurice, 109

Hargest, James 'Jimmy', $96 n$

Harrison, James, 25

Harrison, Woodthorpe Jude

'Thorpe', 17

Harvey, Marcus Dalby 'Mark', 2, 4n, 7, 21, 35, 79

Hawksworth, William 'Bill', 49, 55, 62, 115

Heß, Rudolf Walter, 109

Heiden, Konrad, 31, 33

Hemingway, Ernest, 45n

Henley, James Francis Aloysius, 80

Hitler, Adolf, 14n, 29n, 31n

Hulme, Alfred Clive, $2 n$

\section{I}

Inglis, Lindsay Merritt 'Whisky

Bill', $107 n$

Inglis, Roderick William, $88 n$

Isherwood, Christopher, $8 n, 18 n, 43 n$

J

Jeffries, Ulric James, 106

Jones, Idris Deane, 39

Jones, Noel, 19, 54

Joseph, Michael Kennedy 'Mike', 39,

47

Joyce, James, 45, 46n, 52n
K

Kant, Immanuel, $37 n$

Kennedy, Michael John, 25, 81

Kerr, Philip, 36

King, Rex Keith, 13, 15, 18, 20, 22, 24-27, 33, 34, 49, 56-58, 62, $64,68,71-77,80,88 n, 90,98$, 99, 105, 107

Kippenberger, Howard 'Kip', 25n, $100 n, 107 n$

\section{$\mathbf{L}$}

Landau, Romauld 'Rom', 67

Laval, Pierre, 43

Le Lievre, Clement Auguste, 76

Leaf, Harding Waipuke, 117

Leckie, Douglas Farquharson, 34, 35, $56,57 n, 60 n, 62,67 n, 67,106$, 107, 109, 112

Lee, John Alfred Alexander, 53

Lhomond, Charles François, 97

Lindsay, Alexander Dunlop 'Sandy', 41

Linklater, Eric Robert Russell, 93n

Lloyd, Roger Kynaston, 30, 52

Lovelock, John Edward 'Jack', 36

Lowell, Robert, in

Loxton, Geoffrey Ernest, 30

Lusk, William Brian de Laval, 115

M

Macky, Neil Lloyd 'Polly', 72n, 100

Manning, Olivia, $8 n$

Manson, Ian Oliver, 20, 21, 26, 27, 46, 58,62

Martin, James Bennith, 88

Massey, Hart Parkin Vincent, 22

Maugham, Somerset, $43 n$

Maunsell, Terence Arthur Mears

'Terry', 102

McClung, Mark, 41n, 84 
McCullough, Bernard Edward Paul 'Teddy', 33

McGregor, Arthur Francis Gordon 'Mac', 92

McKay, Wattie Horton, 51, 56, 59, 73, 74

McPhail, Edward Alan, 34

Meiklejohn, Matthew Fontaine Maury, 55, $84 n$

Milner, Frank, 53

Milner, Ian Frank George, 9n, 53

Moodie, Alfred Whiting 'Alf', 65, 77, 109

Morkane, Cecil John, 50

Morten, Thomas Bassett 'Tom', 2, 22, 26-28, 35, 62, 91, 107n, 107

Mulhern, Michael Edwin 'Mick', 101

Mussolini, Benito, 76, $77 n$

$\mathbf{N}$

Nancarrow, Donald Hewitt, 94, 96

Newton, Isaac, $85 n$

Noakes, Norman de Berri, 6, 19

Norris, Peter Thornton, $9 n$

Nunn, Guy Theodore, 13, 39

\section{O}

Orbell, Richard Mitchell Scott 'Dick', 26n, 52, 62n, 109

$\mathbf{P}$

Palmer, Geoffrey Blake, 50, 55, 115

Park, Ralph George, 92, 115

Pascal, Blaise, 105n

Patterson, David Moore, 118

Patterson, Ivan Hislop, 117, 118

Peckham, Edgar George Ashby, 8, 100, 106

Powell, Anthony Dymoke, $46 n$

Priestley, John Boynton 'J.B.', $48 n$

Pugh, Thomas Jacob Graham

'Tom', 62

Pym, Barbara Mary Crampton, 9n, 41n
Pyper, Arthur Spring-Rice, 30, 52, 84

Q

Quinn, Arthur Henry, 88, 91

$\mathbf{R}$

Rait, James Owen, 91

Rex, see King, Rex Keith

Richards, Edwin Ernest 'Ted', 10, 11, 20

Romans, Reginald Everans [Everard]

'Reg', 56, 62, $81 n$

Ross, Angus, 81n, $91 n$

Runyon, Damon, 22

Russell, Bertrand, 84n, 106n

Ryan, Augustine John, 28

\section{S}

Sabry, Ahmed Munir (Mounir)

Hassan, 62-64, 108

Sadleir, Michael, 43, 45

Samuel, Herbert Louis, 67

Sand, George, 34n, 45n

Sandy, see Thomas, Walter Babington 'Sandy'

Scoular, James Crawford, 109

Shakespeare, William, 51, 52n

Sheely, William, 72, 100

Shermund, Barbara, $37 n$

Simmonds, Kenneth, 109

Simpson, Wallis, $15 n$

Sitwell, William Reresby 'Bill', 30 n

Smith, Harold Maxwell 'Max', 99n, 99

Smith, Henry Albert 'Congo', 85, 88n, 100

Smith, Reggie, $63 n$

Smuts, Jan Christiaan, 59n

Stafford, William Archibald 'Bill', 25

Stanley-Smith, Mary Constance, 42, 43, 48

Stark, Freya Madeline, 63n

Stewart, Ronald Swanson 'Ron', 49, 67, $110,114,115 n$ 
Swift, Jonathon, $51,52 n$

T

Teleki de Szék, Pál János Ede, 78

Temple, Shirley, $108 n$

Tennyson, Alfred, $18 n$

Thomas, Walter Babington 'Sandy', $2 n$, $26,34,35,68,73 n, 80,91,92 n$, $101 n, 107,108 n$

Thomason, Herbert Henry 'Bert', 2, 4n, $62,80,85,90 n, 112$

Thomson, Frederick Sleigh Roberts 'Ted', 10, 27

Todd, Alexander Hannah, 88n

Toon, Martin Sherrard, $35 n$

Trollope, Anthony, 34n, 46n

Tulley, Roy, 25

Turton, Edmund Christopher, 6on

Twhigg, John Martin, 116, 118

V

Van Gogh, Vincent, 47n, 102n
W

Walker, Jack George, 60

Wallace, Edgar, 22

Watson, Carl Nelham, 2, 112

Waugh, Evelyn, 8n, 30n, 43n

Wavell, Archibald Percival, $64 n$

Webb, Mary, 104

Weir, Robert McLean, 88

West-Watson, Keith Campbell, 9, 14, 21, $25,60,76 n$

Westenra, Derrick Fitzgerald, $104 n$

Wilde, Oscar, $27 n$

Winnie, see Davin, Winifred Kathleen 'Winnie'

Wintringham, Thomas Henry

'Tom', in

WW, see West-Watson, Keith Campbell

Y

Young, Robert Carmichael 'Bob', 110, 113

\section{Z}

Zernatto, Guido, 34

This document was typeset in Adobe Minion Pro using ETEX. Lemma notes were handled by the reledmac package. It was converted from a TEI-encoded source file using a Python script written for the project available at http://github.com/fizzbucket/tei_transformer/. 